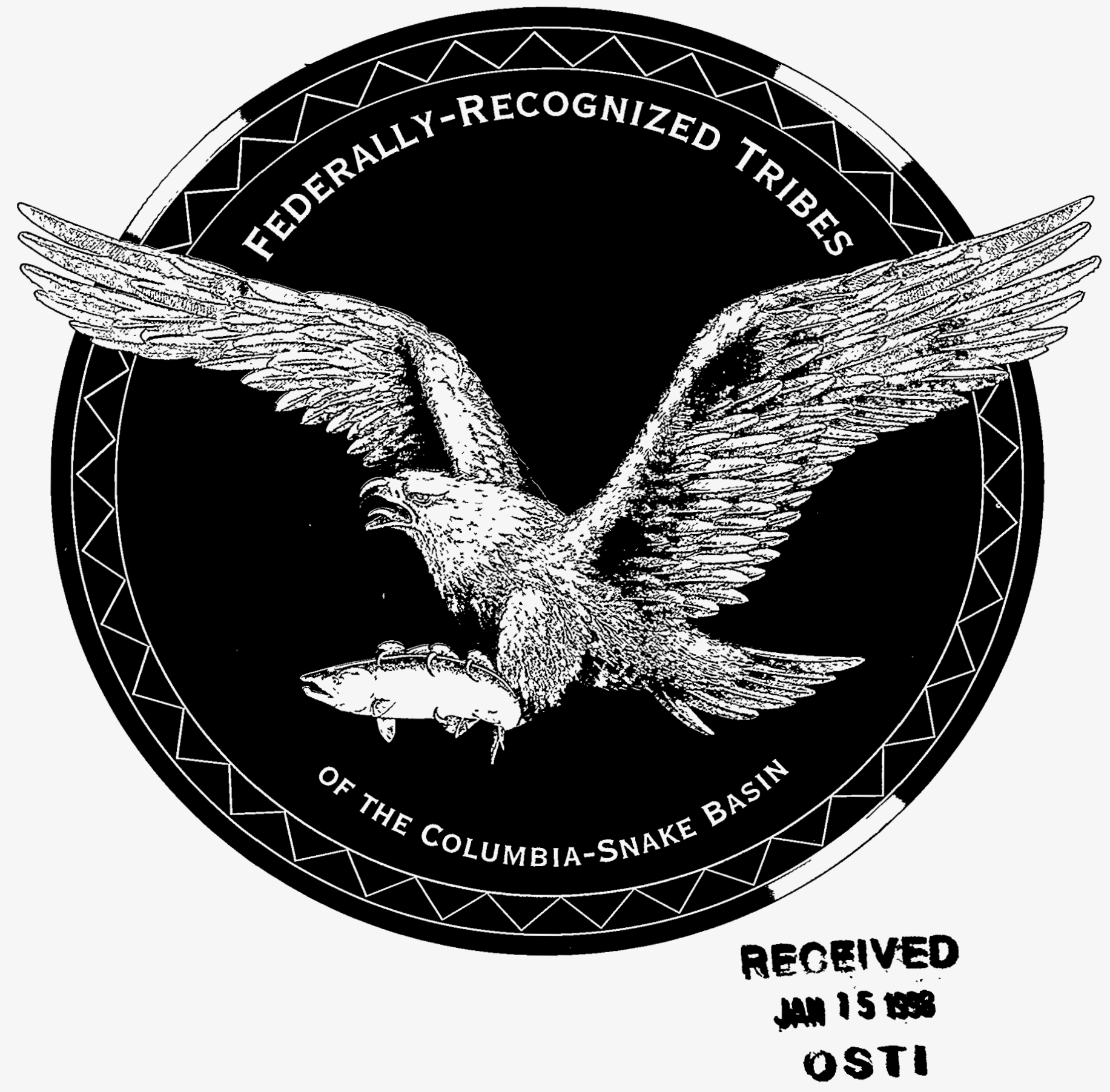




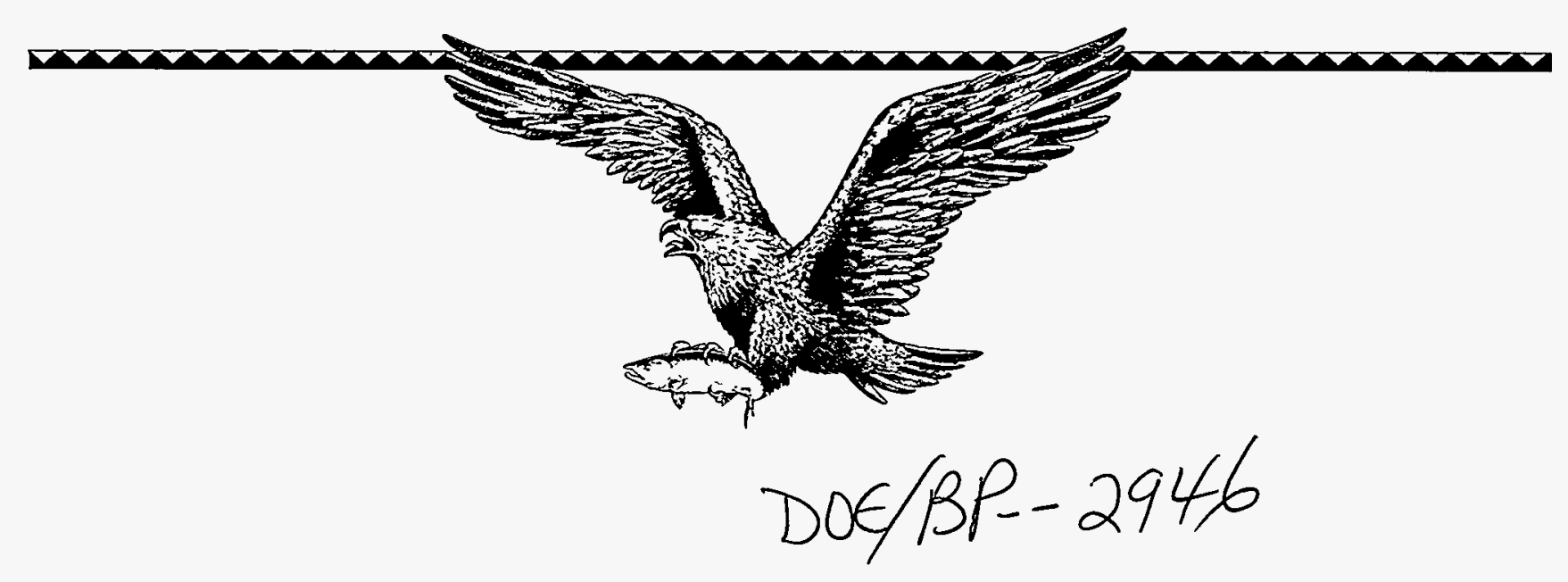

\title{
FEDERALLY-RECOGNIZED TRIBES OF THE COLUMBIA-SNAKE BASIN
}

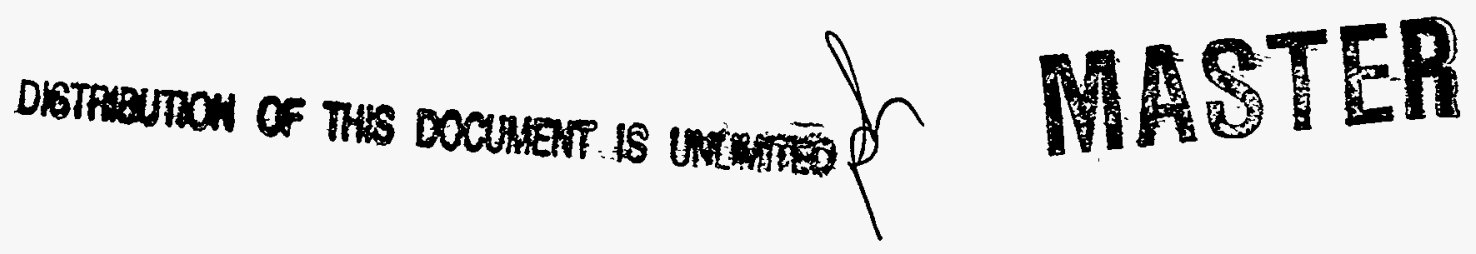

\author{
U.S. ARMY CORPS OF ENGINEERS \\ U.S. BUREAU OF RECLAMATION \\ BONNEVILLE POWER ADMINISTRATION
}


"Water is the lifeblood of Mother Earth and the Salmon is the lifegiver to the indigenous peoples of the Columbia River."

Darrell M. Eastman, BPA Tribal Liaison 


\section{DISCLAIMER}

This report was prepared as an account of work sponsored by an agency of the United States Government. Neither the United States Government nor any agency thereof, nor any of their employees, makes any warranty, express or implied, or assumes any legal liability or responsibility for the accuracy, completeness, or usefulness of any information, apparatus, product, or process disclosed, or represents that its use would not infringe privately owned rights. Reference herein to any specific commercial product, process, or service by trade name, trademark, manufacturer, or otherwise does not necessarily constitute or imply its endorsement, recommendation, or favoring by the United States Government or any agency thereof. The views and opinions of authors expressed herein do not necessarily state or reflect those of the United States Government or any agency thereof. 


\section{DISCLAIMER}

Portions of this document may be illegible electronic image products. Images are produced from the best available original document. 


\section{INTRODUCTION}

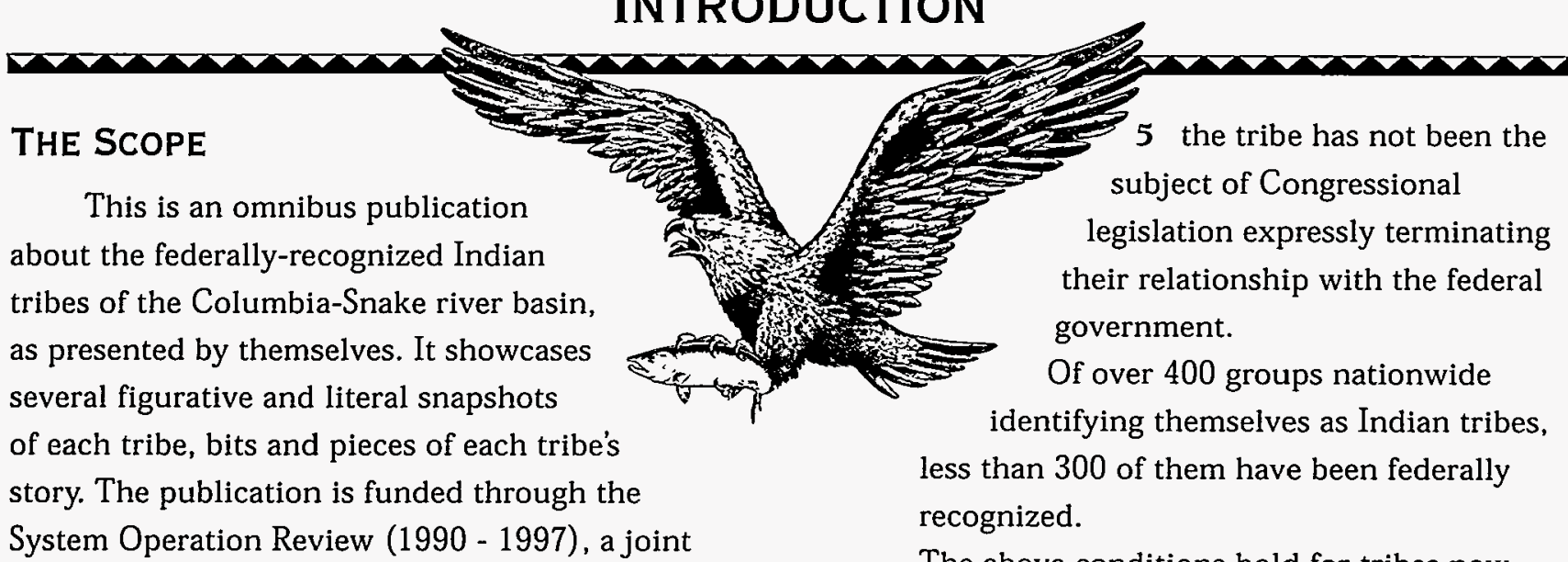

The above conditions hold for tribes now study by the U.S. Army Corps of Engineers, the U.S. Bureau of Reclamation, and the Bonneville Power Administration of the Columbia-Snake hydrosystem. Each individual tribe or tribal confederation either submitted its own section to this publication, or developed its own section with the assistance of the writer-editor.

\section{WHAT IS A FEDERALLY-RECOGNIZED TRIBE?}

A federally-recognized tribe is an individual Indian group, or confederation of Indian groups, officially acknowledged by the United States government for purposes of legislation, consultation and benefits. To achieve federal recognition, an Indian group petitions the office of the Secretary of the Interior. An Indian group qualifies if it can demonstrate that:

1 the group can be identified by historical evidence, written or oral, as being an American Indian tribe;

2 its members are descendants of an Indian tribe that inhabited a specific area, and these members continue to inhabit a specific area in a community viewed as American Indian and distinct from other populations in the area;

3 the Indian group has maintained governmental authority over its members as an autonomous entity throughout history until the present;

4 the membership of the group is composed principally of persons who are not members of any other Indian tribe; and applying to the U.S. Department of the Interior for federal recognition. An additional distinction may also be made among federally-recognized tribes, which is the distinction between "treaty" tribes and "executive order" tribes. Treaty tribes are tribes whose tribal status was recognized through treaty negotiations between the U.S. Government and the tribes during the mid-to-late 19th century. Following culmination of the treaty process in the late 19 th century, many tribes were granted tribal status through executive order of the U.S. President. Where the relationship of treaty tribes to the U.S. Government is bounded by the terms of individual treaties, those provisions may or may not apply to executive order tribes.

\section{WHAT IS THE COLUMBIA-SNAKE BASIN?}

The Columbia-Snake basin, for purposes of this publication, includes the watersheds of the Columbia and Snake rivers, and the tributaries to the Columbia and Snake. Major tributaries are the Kootenai and Flathead rivers in Montana, the Clearwater River in Idaho, the Okanogan, Yakima, Spokane, Pend Oreille rivers in Washington, and the Deschutes and John Day rivers in Oregon. The basin also includes the lakes feeding or fed by these rivers, such as Flathead Lake in Montana, and Lake Pend Oreille and Lake Coeur d'Alene in Idaho. The tribes speaking in this publication have a direct interest in the Columbia-Snake River operations either because the mainstem, tributaries, and/or lakes water the tribes' reservations, or because they water territories ceded by the tribes to the U.S. Government. 
There are other groups of Indians living up and down the river system that are not represented in this publication. Some are bands of larger tribes living off-reservation, and others, such as the Celilo, represent a distinct tribe that persevered on the river in an attempt to conduct their traditional way of life. In many ways conditions are dire for these groups since they do not share the fruits of federal recognition. Still, they maintain close ties through culture, family and friends with most of the federally-recognized tribes, and are not forgotten by them.

\section{How to Use This Publication}

This publication is designed to be used both as a resource and as an introduction to the tribes. Each tribe or tribal confederation is represented in its own tribal section, composing a publication of 13 sections, an introduction, and an appendix containing a description of major legislation affecting the tribes.

Within each individual tribal section, there are three major design elements:

I the main narrative, beginning on page one of each section and continued throughout, which contains in-depth information on each tribe;

2 a "quick-fact" profile of the tribe provides easily accessed statistical information on the tribe and information on how to contact the tribe; and

3 one or more sidebars scattered throughout the section dealing with a variety of issues. While the "quick-fact" profile is designed to allow this publication's users to contact the tribes efficiently, the narratives and sidebars should equip the user with enough knowledge of the tribe to contact them successfully.

\section{NOTES ON CONTENT}

Decisions on the content of each tribal section rested with the individual tribe or confederation of tribes. Each tribe has its own issues and concerns, its own message and voice, and there has been no attempt to coordinate the format or content of the sections. The lack of standardized content or format leads to a wide variety of stories and tones in this publication. That is as it should be, since each tribe prides itself on its unique culture and history.

However, taken together, the sections present a rich picture of regional Indian culture and history, as told by the tribes. In other words, it is hoped that the whole is greater than the sum of its parts.

A patient reading of this publication creates a learning experience similar to that created through the oral tradition that is so important to these peoples. In the oral tradition, members of the extended family, tribal elders and other tribal leaders disseminate spiritual, historical, cultural and practical information to their juniors through a ritual retelling of tribal traditions. A young Indian growing up might hear many stories about many things told in many voices; and yet, as the young Indian matures, the stories and voices begin to coalesce in his or her experience into simple coherent life-lessons. So too in this publication, one section relates the story of the reservation through the eyes of a child; another relates the story of the old days through the eyes of an elder; another section relates the story rhetorically making a point about where the tribe has come from, and why. Some sections rely on Western academic traditions, citing historical sources, etc. Some sidebars tell traditional stories; others talk about current reservation programs. All the stories and modes of representation may, by the end, be thought of as adding up to a whole.

In addition to the natural synergy of the tribal sections working together, there is a convergence of concerns that allows certain sidebars to translate roughly across all sections. For instance, the Umatilla policy of reburial of human remains, while perhaps not worded exactly as another tribe might word it, expresses the sentiments of many tribes. 


\section{WHY READ THIS PUBLICATION}

For the reader coming out of the Western academic tradition (most of us), the presentation may seem disjointed and not helpful. We are trained to identify a point $A$ and a point $B$, and then get from one to the other as quickly as possible.

Getting from point to point efficiently is fine, but there is another question: Are we learning? What are we learning? Certainly linear thinking works perfectly for math or physics problems; but how effective is it in learning about other cultures, which may be non-linear in their deep structures, and therefore not as easily susceptible to linear analysis? To use an analogy, is it more helpful to study the geometry of a circle by thinking of it as a square with its corners cut off, or by addressing the unique geometrical properties of it as a circle?

In analyzing cultures with holistic world views by reducing them to their constituent parts for instance, looking at fishing in an aboriginal culture as a subsistence activity only, without regard to how it is ramified by ritual and tradition, and it turn ramifies throughout the rest of the culture - we are analyzing a circle as if it were a square with its corners cut off. In the cultures in this publication, fishing is not just fishing; it is also worship of the Creator, the way by which the peoples identify one another and place each person into the cultural whole, and many other things. That is why reading a story about Coyote bringing fish is as important to understanding fishing as reading about fishing technology.

Having said this, it is also important to note that traditional culture is not synonymous with primitive superstition. All of these cultures had not only fully-developed cosmologies before the advent of Euro-Americans, but fully-developed technologies as well. Traditional fishermen did not thank the Creator for salmon, and then expect the salmon as a result of the fishermen's prayers to flop on the bank. They prayed; and then they applied their technological know-how to quite successful fishing. This is a truism that is sometimes missed by casual students of traditional cultures. As one elder and tribal leaders said earlyon in the process of putting this together: "We need to teach people that it is possible to fish from an aluminum boat and still be a traditional Indian."

This publication, taken as a whole, should point the way. Reading the entire publication permits learning in a way that approximates the experience of learning in many of these cultures. And if there is one common message that rings through all the sections, it is that traditional cultural values are not dead. They are not historical artifacts. The people of this publication cling to them tenaciously. Traditional culture continues to live on in the sweatlodges and longhouses, at the feasts and giveaways, in the traditional prayers before meetings of the tribal councils, in resource management plans and operations, and in decision-making. 


\section{HISTORICAL BACKGROUND}

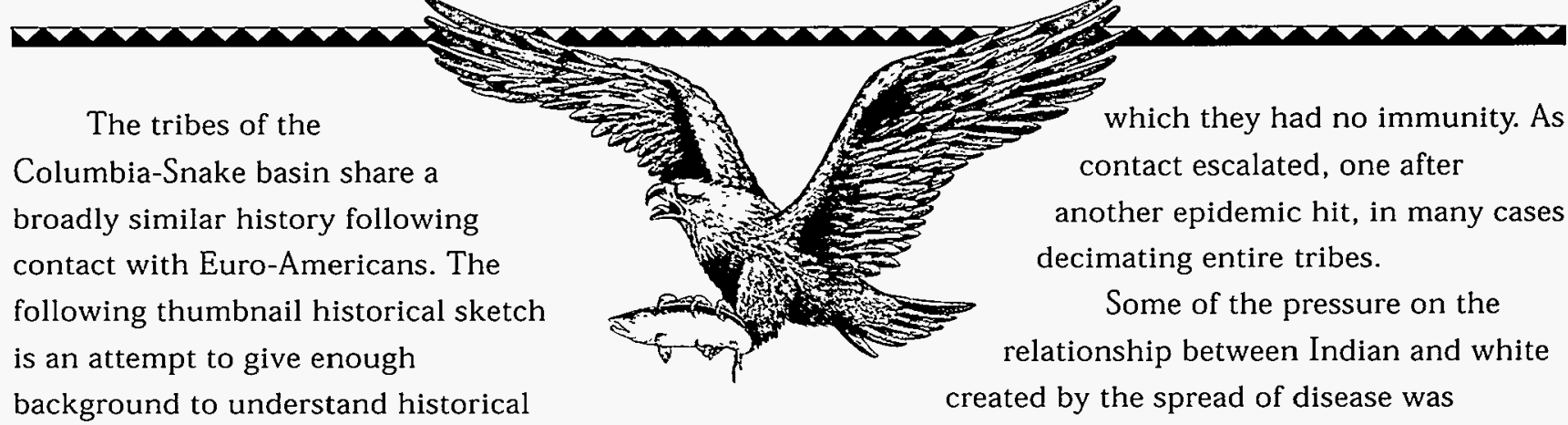

references in individual sections, based on what the editor believes to be points of agreement between Western academics and these tribes.

\section{TH AND 19TH CENTURY}

Prior to 1804, contact between whites and Indians of the plateau and Great Basin was confined to either rumor, as word of European and American traders plying the Pacific Coast drifted inward, or commerce with Hudson Bay Company fur traders making their way into the interior from Canada. With profits - as opposed to settlement - as their goal, the fur traders had little impact on the Indian way of life, and relations tended to be mutually beneficial.

From 1804 to 1806 Meriwether Lewis and William Clark led the first overland American Expedition to explore the lands of Louisiana Purchase, bought from France by U.S. President Thomas Jefferson. The expedition made its way up the Missouri River, over the Bitterroot Mountains along the present Idaho-Montana border, along the Snake River in Idaho, and eventually down the Columbia River to the Pacific Ocean. Lewis and Clark too met with mostly friendly Native Americans, and their journals are full of references to assistance they received from tribes and individuals along the route.

For years following the expedition, contact remained confined to exploration and trade. The relationship was carried out on an equal basis, with the tribes free to range throughout their aboriginal territories, composed of hundreds, and often thousands, of square miles. Even at this point, however, they were paying a price for contact, as disease spread to them from whites, for lessened by the fact that, with their cultures still intact, Indians could treat disease and its aftermath with traditional spirituality and emotional healing. This advantage was soon to be challenged with the arrival of missionaries. Catholic missionaries began penetrating the northern plateau from predominately Catholic Canada in the 1830s, followed by Protestant missionaries who established missions mostly among downstream tribes. Long impressed by white technology and perceived power, most of the interior tribes originally requested missionaries. The missionaries, for their part, while generally treating Indians paternalistically, often interceded on their behalf when troubles began over an influx of settlers at mid-century. As more settlers moved into the area, and the tribes' numbers continued to be reduced by disease, suspiciousness and anger replaced their initial curiosity. Inevitably, since the missionaries had penetrated deepest into the Indian way of life, they became the focus of the anger.

Minor flare-ups between American immigrants into the interior and Indians became more numerous and hostile by mid-century, as the migration west peaked. In 1847, a band of Cayuse, suspicious that missionary Marcus Whitman and his wife were deliberately spreading disease among them, killed Whitman and his wife at their mission near Walla Walla, Washington. This incident both initiated the organized Indian wars of the next several decades - beginning with the Cayuse War in 1848 - and firmed the resolve of the federal government to remove the tribes to reservations. In 1855, Washington territorial governor Isaac Stevens set out on a treaty-making 
mission with Washington tribes, while General Joel Palmer did the same with Oregon tribes. The process was long, convoluted and confused. Several tribes would be gathered in a single spot, and days-long confabulations would begin between U.S. negotiators, translators and the Indians. Seldom did the Indians understand exactly what they were signing, and often Indian signatories were chosen by the Americans themselves on the likelihood that the chosen chiefs would sign.

The result was treaties that removed many tribes to reservations in return for the tribes ceding thousands of square miles of their aboriginal territories. The treaties usually contained other provisions for the delivery of supplies to the reservation, compensation, and training.

Actual removal of the tribes to the reservations itself was a long, convoluted process. Many tribal members felt misrepresented by the process. The treaties forced concepts of ownership on them that were totally alien - they felt the land and water belonged to the Creator and no one else - and even given that they now "owned" the reservations, the reservations were far removed from the traditional areas from which they drew both their subsistence and their spiritual strength. While many Indians moved to the reservation, many did not. For the next three decades, hostilities with settlers escalated, leading to increased warring with the federal government. Meanwhile, the discovery of gold on many reservations, and the increased demands of settlers for land, led to the federal government reducing the size of many reservations and allocating the land to whites. Significant encounters between Indians and the U.S. military took place in the interior, beginning with the Yakima War of 1855 and ending with the Nez Perce War of 1877.

Meanwhile, life on the reservations became increasingly desperate as supplies and training promised under the treaties either did not arrive or were substandard. Although the stated aim of U.S. government policy was to create independent, civilized populations on the reservations, usually meaning populations of farmers, most reservation land was unsuitable for farming. Deprived of their traditional way of life, Native Americans had little with which to replace it. Toward the end of the 19 th century, in response to the desperation, charismatic and millennial Indian religious movements began to spring up such as the Ghost Dance religion on the central plains and the Washat religion in Washington state, led by the prophet Smohalla. These religions called for a return to traditional ways, in order that Indians could regain their lands, reunite with their ancestors, and gain peace and prosperity.

The final chapter in the hostilities took place at Wounded Knee Creek in South Dakota. Frightened by the Ghost Dance, settlers called on the U.S. government for protection. Sioux chief Sitting Bull, thought to be an instigator, was shot as he was confined in a cell. His followers fled, and were rounded up near Wounded Knee, including 200 unarmed men, women and children. In the confusion of securing the encampment, shots were fired. The nervous troops opened fire, killing everyone. This marked the end of significant organized resistance throughout the west. History between the U.S. government and Indian tribes since has largely been written through the federal courts and the U.S. Congress.

\section{TH CENTURY}

Under the law, treaties with Indian tribes are agreements between sovereign nations and, as such, constitute the supreme law of the land. They cannot be changed or superseded by any authority other than a majority vote of the U.S. Congress. Also, subsequent interpretation of the treaties have identified a trust relationship between the tribes and the federal government, in which the government is obligated "...to provide those services required to protect and enhance Indian 
lands, resources, and self-government, and also includes those economic and social programs which are necessary to raise the standard of living and social well-being of the Indian people...."

As a consequence of treaties and trust responsibility, Congress is responsible for creating Indian policy, which is then carried out by the Department of the Interior. Based on Congress' shifting view of what is best for the "well-being of the Indian people" in the late 19th and 20th centuries, federal Indian policy has shifted frequently. Here again is a thumbnail sketch.

Following 30 years of reservation life, during which the tribes attempted to augment traditional subsistence with some agriculture, in 1887 they were faced with the consequences of the General Allotment Act - or Dawes Act. The intent of the act was to civilize the Indians by allotting them individual parcels of reservation land on which to farm or ranch - to introduce them to the concept of private property, in other words - and also, by selling off "surplus" parcels to settlers, to introduce the supposed civilizing influence of whites onto the reservation. Under the act, the reservations were split into parcels that were granted to individual Indians and their families, with the remaining allotments open for sale to the general public. Even if most Indians had wanted to be farmers, the reservations were generally not suitable for small-scale farming. Many Indians sold their parcels to whites, or lost them in foreclosures when they could not afford the taxes on the land. Only 50 million acres of communallyheld land remained in tribal hands by 1934 , of the 140 million acres held before 1887 .

In 1934, in an effort to restore tribal fortunes, Congress passed the Indian Reorganization Act. The act halted the sale of allotments and restored unsold parcels to the tribes. Congress also established $\$ 10$ million in credit for the tribes. However, before a tribe could borrow, it had to incorporate. This began a serious movement on the part of the tribes to modernize their governments, which ultimately entailed forms of government alien to traditional decisionmaking. The radical egalitarianism that had marked the Plateau and Great Basin cultures was often replaced by factionalism and internal strife. While virtually all of the tribes in the 60 years since the Act have refined their governmental organizations into efficient tribal councils, early efforts led to hard feelings that, in some cases, remain today.

In 1953, with the passage of House Concurrent Resolution 108, Congress again shifted policy toward what became known as "termination." Under the resolution, benefits and support for over 100 federally-recognized tribes summarily stopped. Each of the tribes was ordered to distribute its land to tribal members and dissolve its government.

Termination brought the tribes to the brink of economic collapse, and in 1968 the policy was reversed in favor of a policy that promoted Indian self-determination. Laws have since been passed promoting economic and political selfdetermination. Federal Indian policy for the future remains to be seen.

\section{CONCLUSION}

Conventional academic study of traditional aboriginal cultures requires compartmentalization of them into their perceived constituents. The very term "cultural complex" assumes the existence of simple parts, such as religious, subsistence, social and political activities and institutions, etc., that compose the whole. This analytic method, at least in the first phases of study, is a typically Western way of looking at things.

One may analyze an equation or an airplane, because they are constructed from individual constituents deliberately for this type of analysis. Oddly, this is not the way that culture actually operates for any of us, and certainly not for Indians. For Indians, their culture is not an engine, the parts of which may be removed, 
buffed, studied and compared. It is holistic, with all activities interlocking and ramifying one another. Also, their lifeways were given them by the Creator, rather than developing over time. It may be said that for them, it is not even their culture; it is the Creator's creation, of which they are a part; and to understand them, one must begin by understanding the Creator and creation.

A simple example of this is how language works in their cultures and what happened when it was discouraged. Language is not just a medium for the exchange of information, but a way of seeing the world; in fact, a way of life. Language expresses the categories in which a people see the world, and the values they place on those categories. "The world" is coextensive with those categories and values. When Native Americans were forced to learn English and discouraged from speaking their own language, they did not just lose language; they lost traditional meaning and order. Entire categories of their existence disappeared for Indian-speakers that could not be expressed in English because English-speakers did not recognize those same categories in their own culture, nor in their language.

Besides the culture losing much content with the loss of language, the ability to continue basic cultural operations was compromised. For instance, Western academics have in the past discounted oral tradition as a legitimate form of historical transmission, mainly on the basis of its perceived unreliability. What many of them failed to recognize until recently is that in tribal cultures, oral tradition is a hallowed craft. A premium is put on retelling stories accurately and consistently - particularly stories concerning what Westerners would call "historical events." Oral tradition is not an art; it is not a creative, ego-involved activity. Embellishment and creativity are discouraged, and to the extent that native storytellers do embellish, it is considered a perversion by non-Indian influence of the object of storytelling - which is to transmit the culture
- much as desire of some Indians to hunt trophy game is considered by traditional hunters an egotistical perversion of the object of hunting which is to put food on the table. To the extent that stories have changed over the centuries, it is mostly due to the forced acceptance of a new language foreign to the original stories. So the culture lost content, while the structure of cultural transmission was compromised as well.

Losing the Indian language diminished the content and structure of the culture. Just as bad, it introduced a gulf between the generations that spoke the traditional language, and their children, who began to think of the language, and hence their elders, as being backwards and irrelevant.

Finally and most drastically, Indian life lost much of its spiritual center with the loss of language. It became desacralized in that the language had been given them by the Creator. Now they had forsaken this sacred link with the Creator, which became a source of shame for them.

If to many of us who do not think much about it, language is just language, for these tribes, language was a block in the edifice of their culture. Talking about its loss this way suggests that it was a central element; but that too would be to misunderstand. Language was not central, because nothing was central. It was all part of the whole. Once removed, much came tumbling down.

The structure and function of this publication attempts to recall that edifice, but also to look toward the future. Again, it is important to remember that the information and messages contained in the individual tribal sections are considered to be important for a better understanding of each tribe, within the scope of this publication. Each section is a snapshot, and does not contain the full range of issues, or the richness of experience, of the tribe. 


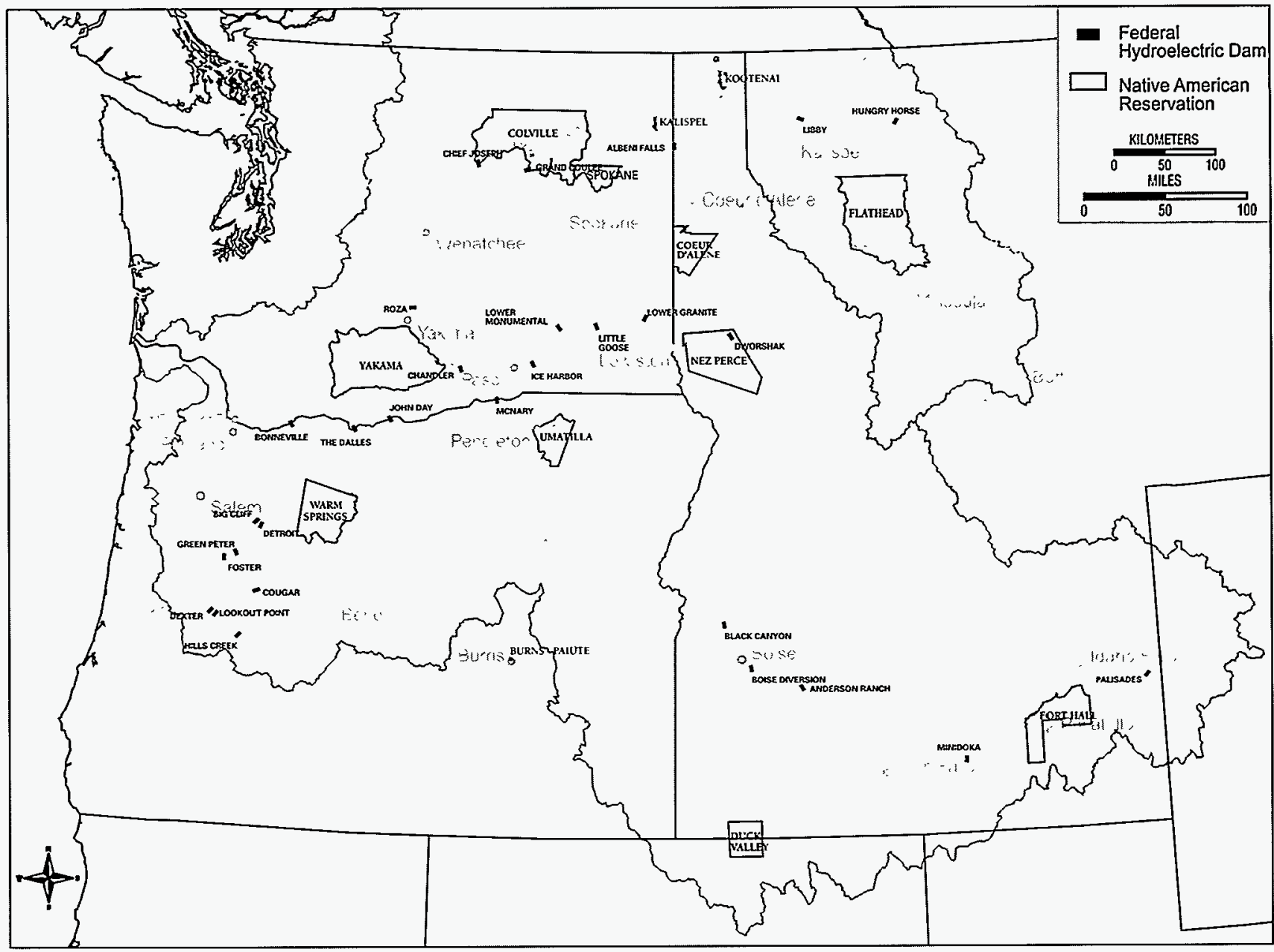




\section{READING LIST}

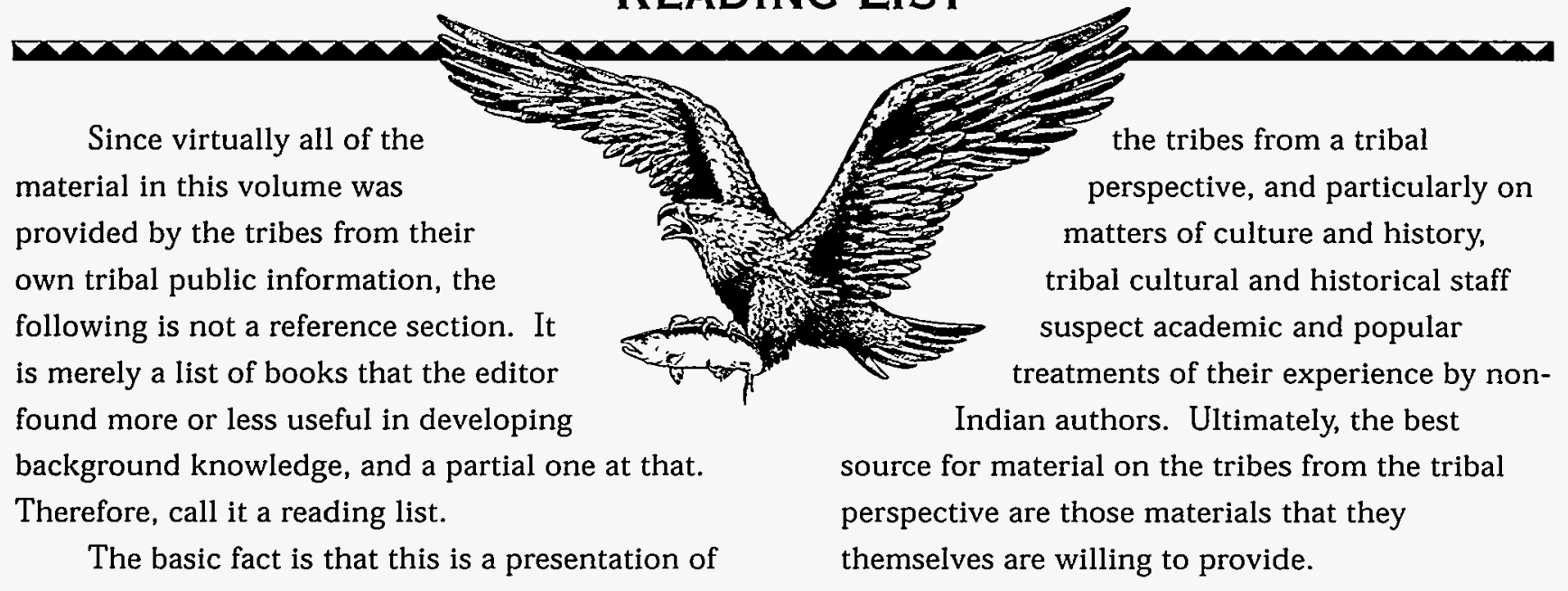

Boaz, Franz and Teit, James. Coeur D'Alene, Flathead, and Okanogan Indians. Fairfield, WA. Ye Galleon Press.

Buan, Carolyn and Lewis, Richard, editors. The First Oregonians. Portland, Oregon. Oregon Council for the Humanities. 1991.

Hines, Donald M. Magic in the Mountains. Issaquah, WA. Great Eagle Publishing, Inc. 1993.

Hines, Donald M. The Forgotten Tribes. Issaquah, WA. Great Eagle Publishing, Inc. 1991.

O'Donnell, Terrence. An Arrow in the Earth. Portland, OR. Oregon Historical Press. 1991.

Pevar, Stephen L. The Rights of Indians and Tribes. Carbondale, IL. Southern Illinois University Press. 1992.

Relander, Click. Drummers and Dreamers. Seattle, WA. Northwest Interpretive Association. 1986.

Ruby, Robert H. and Brown, John A. A Guide to the Indian Tribes of the Pacific Northwest. Norman, OK. University of Oklahoma Press. 1989

Hunn, Eugene. Nchi' Wana, The Big River.

Lesley, Craig. River Song. New York, New York. Bantam Doubleday Dell. 1989.

Lesley, Craig. Winterkill. New York, New York. Bantam Doubleday Dell. 1984.

Mourning Dove. Coyote Stories. Lincoln, Nebraska. University of Nebraska Press. 1990.

Mourning Dove. Mourning Dove. Lincoln, Nebreska. University of Nebraska Press. 1990.

Ruby, Robert H. and Brown, John A. The Cayuse Indians. Norman, OK. University of Oklahoma Press. 1972

Robert H. and Brown, John A. The Spokane indians. Norman, OK. University of Oklahoma Press. 1970.

White, Robert H. Tribal Assets. New York, New York. Henry Holt and Company. 1990.

Wilkinson, Charles F. Crossing the Next Meridian. Washington, DC. Island Press. 1992. 


\section{BuRns PAIUTE TRIBAL PROFILE}

\section{LOCATION AND LAND BASE}

The Burns Paiute Tribe were federally-recognized as an independent Indian tribe on October 13, 1972. The reservation is composed of 770 acres east of the town of Burns, Oregon.

\section{ENROLLED MEMBERS}

There are presently 281 enrolled members of the Burns Paiute Tribe. Thirty-seven percent live on the reservation.

\section{LANGUAGES}

Paiute language

\section{TRIBAL GOVERNMENT:}

The tribal government of the Burns Paiutes was chartered under the constitution and bylaws adopted May 16, 1968, and revised in 1988. Under the constitution, a seven-member tribal council conducts the standard operations of the tribe. The tribal council is responsible to the general council, which consists of all qualified voters (tribal members living on the reservation who are over the age of 18). The general council meets twice a year on important matters. Tribal government includes nine departments.

\section{ECONOMIC BASE}

Ten percent of tribal operating funds derives from the leasing of cropland. The balance is from public and private grants, and public funding.

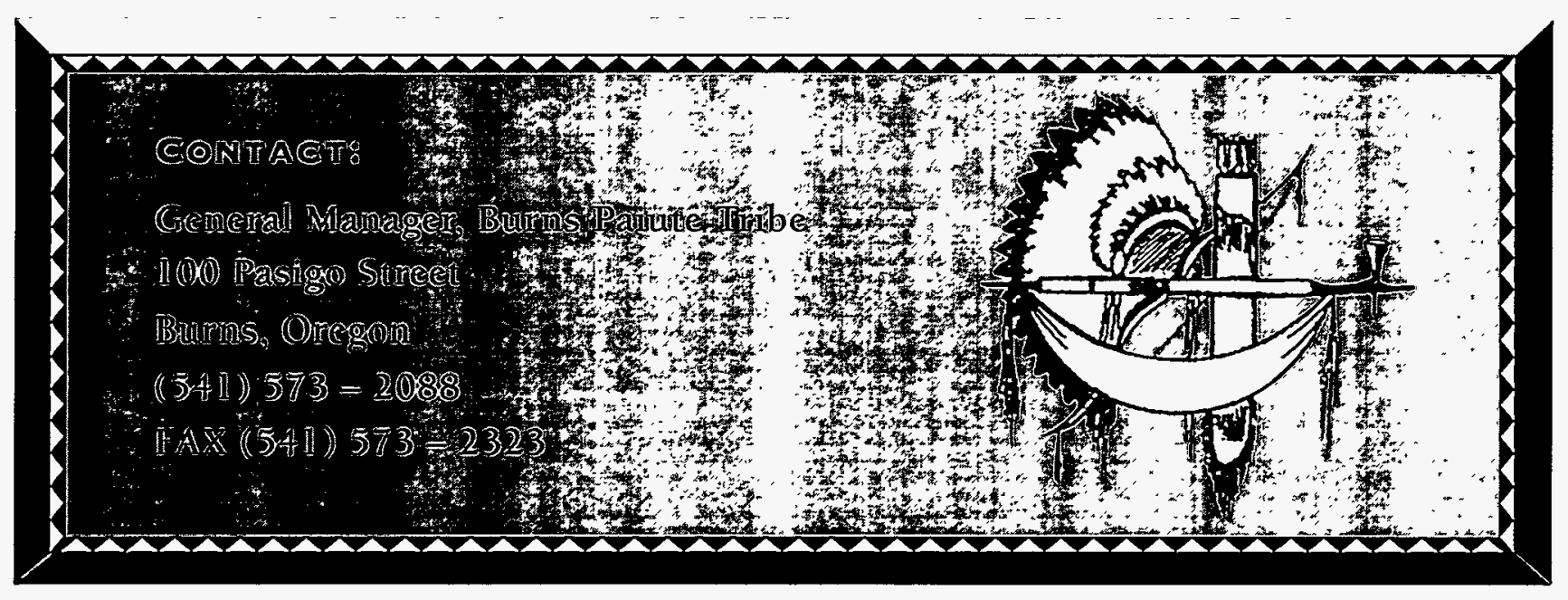




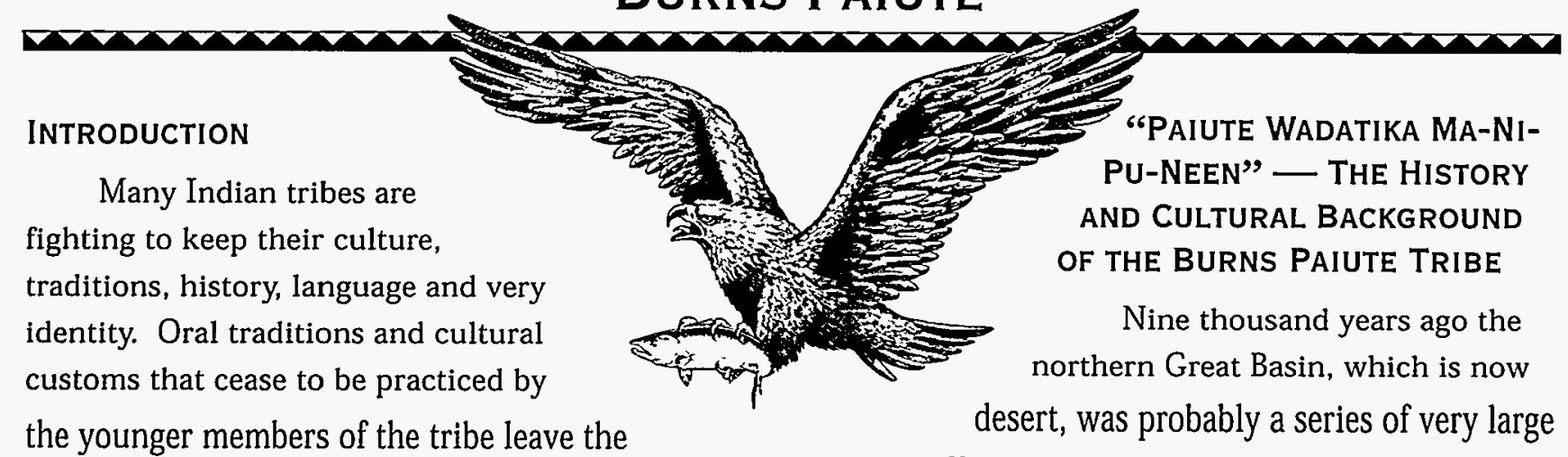

elders with vast stores of untransmitted tribal knowledge. Often this knowledge is lost when the elder dies unless a concerted effort is made to preserve it. Part of this fight to preserve and maintain Indian cultures necessarily includes education. This is true not only for the younger members of the tribe, but also for the greater American public. In order for detrimental myths and unconscious prejudice about Indians to be changed, a great deal of education is needed. No one is going to undertake this task except the American Indian tribes themselves.

The Burns Paiute Tribe has taken up the fight for its cultural heritage. They have started projects researching their history and culture and interviewing tribal members to record their stories and their knowledge. lakes. The ancestors of the Burns Paiute people lived in caves near their shores. Horses, camels, mammoths, bison, elk and deer roamed the hills. These people used the fibers of the tule plant, willow, Indian hemp and sagebrush bark to make woven sandals, coiled and twined baskets and rope. They also made duck decoys, fish nets and traps for small game with these fibrous plants. A beautiful soft blanket woven from the furs of rabbits and child's sandals made from sagebrush fibers were found preserved for close to 10,000 years in a cool dry cave. Archeologists also found clothing made from deer, animal, and bird hides. Their diet included a wide variety of items, such as fish (including a great deal of salmon), birds, deer, small animals, plants and seeds.

During the next 1,000 or 2,000 years the climate slowly became drier and warmer. The lakes began drying up and food sources were less readily available. By 7,500 years ago large mammals such as horses, camels and mammoth were extinct. People began seasonal migrations to take advantage of plants and animals in certain areas. Small family groups would travel separately collecting seeds berries, roots, hunting small animals, deer, mountain sheep, elk, and fishing.

These smaller groups came together to harvest, socialize and intermarry with other Paiutes as well as other Indian tribes. Spring offered roots to be gathered on 
the sunny hillsides and meadows, and fishing for salmon during the salmon runs. During the summer, berries and fruit were collected as food and stored for winter use. By late summer and early fall seeds were the main resource to be gathered. Families also came together during this time of the year for com-munal antelope and rabbit drives. Late fall was the time to collect plant material to make items such as sandals, baskets and clothing during the long winter months. By November the families had gathered their cached goods that they had put away during the months of harvesting. They then gathered materials from the area - sagebrush in the desert or tules near the lakes - and built houses near springs in which to live out the winter. The Paiutes lived in this manner for thousands of years.

The Paiute people believe that they have lived in this area since before the Cascade Mountains were formed. Some researchers, on the other hand, believe that about 1,000 years ago an influx of Paiute-speaking people came from the south and migrated throughout the Great Basin. They brought with them not only their language but also certain types of atlatl and spear points and brownware pottery. Pottery was not found in the Great Basin before this time. However, the

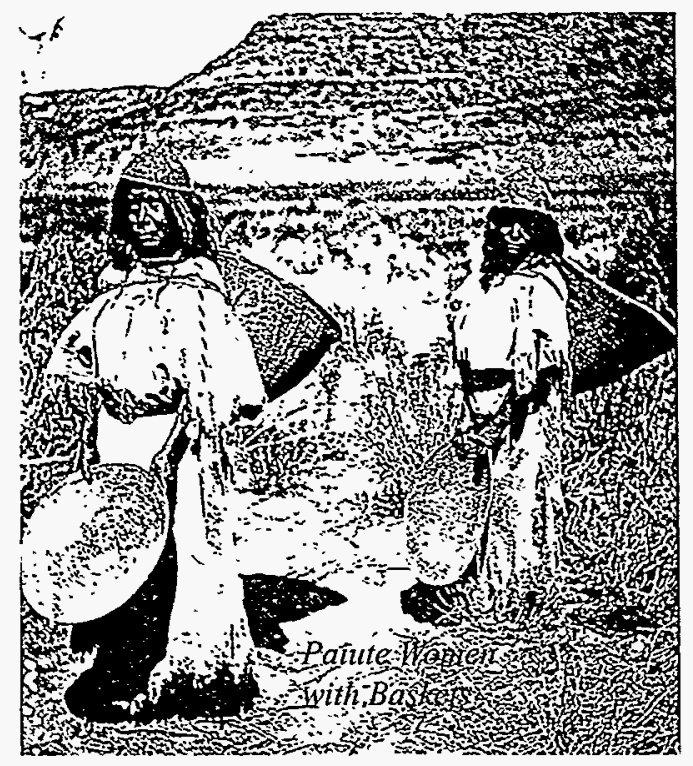

people of the Burns Paiute Tribe were basket makers and did not make pottery. According to the researchers, the language spoken here before the arrival of the Paiute is unknown. This, however, contradicts the Paiute stories and legends, which are handed down from generation to generation that tell of the Paiute people living in the Great Basin for thousands and thousands of years.

Paiute bands were usually named after an important food source in their area. The Burns Paiute Tribe descended from the Wadatika band, named after the wada seeds they collected near the shores of Malheur Lake to use as food. Other Northern Paiute bands were named the "groundòog-eaters" and the "elk-eaters." The Wadatika's territory included approximately 5,250 square miles between the Cascade Mountain Range in central Oregon and the Payette Valley north of Boise, Idaho, and from southern parts of the Blue Mountains near the headwaters of the Powder River north of John Day, to the desert south of the Steens Mountain.

The first Europeans with whom the Wadatika had contact were trappers who explored the area looking for beaver in the $1820 \mathrm{~s}$, '30s, and '40s. By the late 1840s, the relations between the Indians and the settlers were already strained. By that time, many settlers were moving through the area on the Oregon Trail on their way to western Oregon and the coast. Epidemics of smallpox, cholera and other diseases brought into the area by Europeans had swept through the tribe in the 1830 s and 1840s. The diseases killed many Indians, especially the young and the elderly tribal members.

Settlers first moved into what is now Harney County as late as 1862 , years after others had poured into western Oregon. Cattlemen then quickly began to take land up or buy up homesteads to run their huge herds of livestock over the land. The limits of the native ecology were severely stressed due to the grazing of 
livestock by the expanding foreign population and the increase in hunting and fishing by those same people. Resources depended on by the Paiute people were depleted or destroyed. But, as the Paiutes noticed, the settlers brought with them resources of their own: those very livestock and horses that were eating and trampling the Wadatika's food supplies. Raiding wagon trains and camps increased as more outsiders came through the Wadatika's territory and destroyed their livelihood. By the 1840 s, the Northern Paiute bands had acquired horses and guns, and such raids became an important way for the Wadatika people to defend themselves and survive. In response, the U.S. Army set up its first military outpost, Camp Alvord, in 1864. By 1867, Fort Harney was established.

While the tribes to the north, the Cayuse, Umatilla, Wallawalla, and the Wasco, John Day, Deschutes and Tygh, were confined to the Umatilla and Warm Springs reservations by 1856 , the Northern Paiutes continued their seasonal migrations for another decade. During these years the fighting between Indians and the encroaching settlers became bitter, with raids on wagon trains and army surveyors increasing. Punishing parties were sent out by the settlers to kill any Indian seen, whether it was a man, woman or child. The Indians were fighting for their land, culture and very lives.

In 1866, General Crook was appointed to the area to quash the resistance of the Northern Paiute bands and to force them onto a reservation. For the next two years he carried out a devastating and relentless campaign. He broke their usual circular migration pattern and harassed and killed them during the winter, their usual season of rest. By spring of 1868 the Indians had suffered a terrible winter, losing half their total population to starvation, freezing to death and fighting. General Crook then made an offer of "Peace or Death." That year Paiute Chiefs We-You-We-Wa, GshaNee, Po-Nee, Chow-Wat-No-Nee, E-He-Gant
(Egan), Ow-Its (Oits) and Tash-E-Go signed a treaty guaranteeing them a reservation in their homeland. Included were promises that raiding and hostilities toward the settlers would cease in return for army protection from the hostile encroaching settlers. Unfortunately, the cutoff date for signing Indian treaties was passed before the treaty went before Congress; therefore Congress never ratified the treaty.

Several attempts were made in the next four years to move and confine the various Northern Paiute tribes to reservations outside their aboriginal territory. Finally, however, the President signed into law the Malheur Reservation, taken from the larger area of Oregon's entire southeastern corner, which was first set aside for that purpose. The 1,778,560 acres of reservation land included Castle Rock, Strawberry Butte, the Silvies River, Malheur Lake and the North and South forks of the Malheur River within its boundaries. This area was reserved for all bands of Indians still "wandering" in eastern Oregon. Samuel Parrish was appointed Special Indian Agent in 1873. He was well-liked by the Indians, treated them fairly, and went into debt in order to provide the food, shelter, education and resources needed to begin farming. This did not make him popular with the local settlers, and he was replaced by Harrison Linville the next year. There was a great deal of corruption while Linville was in charge - rations were sold rather than handed over to the Indian people for which they were intended. Finally, in July of 1874 , Parrish was reinstated after Linville left, fearing for his life.

Marian Louie, an elder of the tribe, told of the stories she heard from this time. She described life on the Malheur Reservation in a short history of the "Malheur Paiutes" which she wrote around 1973.

"Indians used to bathe in the hot springs near the Agency. During the winter the people wintered in the lowlands. Some buildings were 


\section{Resource Management}

The Burns Paiutes recognize that all tribal resources are closely intertwined, and that the preservation of the tribe and its culture depends on the preservation of all resources.

In 1994, when the tribe put its first cultural resource person in place, there was great consternation among the elders that the culture and the language were being lost. During periods of forced assimilation from 1900 to 1930 when tribal members were sent to Indian boarding school and denied the use of their language, and then again during upheavals on the Reservation in the 1940 s and '60s, much traditional knowledge was forgotten. Loss of the traditional culture creates sadness and anxiety among tribal members who have lived the culture, as they wonder what will replace it. The tribe wishes to restore the traditional culture, both to restore peace of mind to its members, and also to establish management philosophies and plans in all areas of resource management that are consistent with tribal values of balance and harmony with the environment. In other words, before the tribe can effectively plan its operations, it must re-establish its identity and values.

This re-establishment began in 1994 with elder field trips. Trips are organized on a regular basis, weather permitting, to culturally significant areas such as Castle Rock, a traditional prayer site in the Malheur National Forest. Several weeks before a planned trip, the cultural resource manager goes out to tribal elders and solicits candidate-sites for visitation. A notice is put in the tribal newsletter, notifying tribal members of the time, date, and location of the field trip. Other tribal departments provide transportation. Once at the site, elders share information on culturally significant plants, or tell stories about the site, many of which have not been told for years. This both resurrects old knowledge, and transmits it to younger members of the tribe. The program has also been expanded to include tribal, federal and state employees working on resource projects within the aboriginal area of the tribe. Elders go out with these staff and identify culturally significant plants that can be related in their native areas, bringing them back for traditional use.

Recently, the tribe as been focusing on restoring the willow in riparian zones. The Paiute have a 10,000 year tradition of basket-making, and many of those baskets are made of willow. If the willow disappear, only the memory of the craft will survive at first, and then even that will die. Traditional subsistence such as roots and chokecherries are also an area of focus. Recently, the Cultural Resource Department has received grants and assistance from Idaho Power to conduct Global Positioning Surveys around the Snake River system that will result in identification and precise mapping of culturally-significant plant sites. The U.S. Bureau of Reclamation is funding additional such surveys on the Snake River.

The need to preserve the culture through the preservation of significant resources binds the Cultural Resource Program to the Natural Resource Department. Presently, the Natural Resource Department is planning for genetic and habitat surveys on local, significant fish resources such as redband trout on Stinking Water Creek. With this project, and others planned for the near future, the department will identify native and significant fish and wildlife, inventory the amount and condition of their habitats, and develop plans to preserve and enhance the habitats and resources. These projects begin in the field with elders working alongside the Natural Resource Department staff.

Presently, these plans and projects are moving forward, along with more conceptual work on a Cultural Preservation Manual funded by the U.S. Park Service. The tribe is also planning to add GIS capabilities, in order to continue its mapping of significant cultural and natural resources.

Meanwhile, a core group of elders continues to be active developing language and culture programs, and transmitting traditional knowledge to the younger members of the tribe to ensure that traditional values and practices continue invigorate resource programs into the 21 st century. 
erected at the Agency, but were discontinued due to lack of funds, but some years later a school was build for Indian children to learn the ways of farming and digging ditches to irrigate their crops. But life was still not happy, happiness to the Indian is doing and going about their way as did their ancestors." (History of the Malheur Paiutes as told by Marian Louie, Translation by Minerva Soucie, page 2)

The numbers of Indians on the reservation grew under Parrish as groups came down from the hills. By the fall of that year there were over 800 on the rolls. Unfortunately, funds were not increased with the increase in population and they were having great difficulty surviving on the scarce resources, both federal and natural, available to them. Parrish wrote several letters to the President pleading for money and resources. He argued that this was a critical time for the tribe as they were eager to become self-sufficient. They only needed a bit of capital to start a cattle herd and other industries.

During the same period the stockmen and ranchers were pressuring the government to turn over reservation lands for settlement and grazing of cattle. They were not even waiting for a federal mandate, but began to run their livestock and even build ranch homes on the reservation. A particular area of dissension was the valley southeast of Fort Harney, an area important to the tribe for gathering camas. Ranchers fenced this location in order to run cattle there and did not allow Indians in. In January of 1876, President Grant, under pressure from settlers, ordered the northern shores of Malheur Lake open for settlement, an area important to the tribe for wada seeds. This was a blow to the Indians, as was the replacement of Agent Samuel Parrish that summer due to the urging of the settlers. His replacement, William Rinehart, had fought under General Crook, and his derogatory attitude toward Indians had not changed since the war.

Under Agent Rinehart, hostile settlers continued to invade reservation land and appropriations dwindled. Chief Egan gave an eloquent speech against Rinehart and the taking of the reservation by settlers. He said, "Did the government tell you to come here and drive us off this reservation? Did the Big Father say, go and kill us

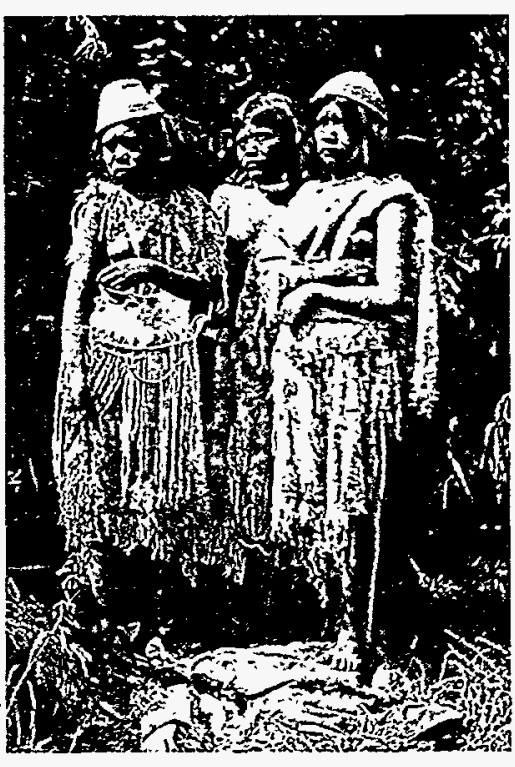
all off, so you can have our land? Did he tell you to pull our children's ears off, and put handcuffs on them, and carry a pistol to shoot us with? We want to know how the government came by this land. Is the government mightier than our SpiritFather, or is he our Spirit-Father? Oh, what have we done that he is to take all from us that he has given us? His white children have come and taken all our mountains, and all our valleys, and all our rivers; and now, because he has given us this little place without our asking him for it, he sends you here to tell us to go away. Do you see that high mountain away off there? There is nothing but rocks there. Is that where the Big Father wants me to go? If you scattered your seed and it should fall there, it would not grow, for it is all rocks there. Oh, what am I saying? I know you will come and say, 'Here, Indians, go away - I want these rocks to make a beautiful home with..." (Hopkins, Life Among the Piutes, pp. 133-34)

The Indians began to leave the reservation, fleeing the worsening conditions. By June of 1878 , tensions came to a head. The deprivations suffered from lack of rations and supplies during the winter and the lack of support from their government agent set the stage for revolt. Then, too, the news came in that an Indian village in the hills had been destroyed by soldiers. Forty-six 
Bannocks looking for allies against the settlers visited the Malheur Reservation and brought news of the Bannock uprising at Fort Hall. Some Paiutes became increasingly convinced that war was the only effective way to bring attention to their plight. They understood the hopelessness of such a war, but they preferred to fight rather than to starve to death.

The Bannock Indian War, as it was later called, consisted of few actual battles, but a resurgence of raiding by the Indians and killing of Indians by the settlers. By mid-July, the Army got the help of Umatilla Indian scouts to the north in a scheme to kill Chief Egan. The Paiutes believed the Umatillas to be friendly and were hoping to find allies at the meeting. Instead, they walked into an ambush. The scheme succeeded, and Chief Egan was killed. With the last of their leaders dead, the Bannocks and Paiutes surrendered. The northern Paiutes who had numbered close to 2,000 ten years before, had lost two-thirds of their people.

All Indians were then rounded up and held as hostages at Fort Harney indiscriminate of who sided with the settlers or those who fought against them. Many of the Indians did not understand why they were being rounded up and brought to Fort Harney. In the coldest time of year, January 1879 , over 500 Paiutes were loaded into wagons or ordered to walk under heavy armed guard to Fort Simcoe on the Yakama Reservation and Fort Vancouver in Washington State. In knee-deep snow the men were forced to march, shackled twoby-two, while the women and children rode in wagons. Another group of women and children were later taken to Fort Boise. The fate of yet another group is unknown. The tribe suffered great loss of life due to this forced abandonment of their home - it was the Paiutes' own 'Trail of Tears."

The majority of those who survived the journey to Yakama found little welcome there and did not stay long. After approximately five years the Wadatika people were allowed to make their long way back home. Many had not survived the experience; others chose to stay with the Yakama; while still others left to live with relatives on reservations of neighboring tribes. The ones who chose to made the long, difficult journey to Burns. They would travel in small groups or individually. Swimming the Columbia River, holding onto their horse's tail, and walking the long miles through the mountains, they eventually arrived in Harney Valley. None returned to the empty reservation still staffed by Agent Rinehart. They were considered outlaws, so they lived on what they could find, hunting and gathering in the hills and quietly working for local ranchers.

In January of 1883 , the reservation was made into public domain, open for settlers to claim under the Homestead Act. As Peter Teeman, a 90 year old elder testified in 1948, years afterward at the Warm Springs Reservation:

"The Bannocks kept their reservation but we, the Paiutes, who remained friends with the soldiers, lost our reservation and were taken to the Yakama and turned over to our enemies. We did not give up our reservation." (Burns Paiute Colony: Its History, Population, and Economy, p.19)

The federal government then gave out 160 acre parcels of marginal land in the Rye Grass area to any who had lived on the Malheur Reservation. Only 115 parcels were ever given out, although many more of the former Wadatika survived. Distrust and fear of the government were running high and more than a few tribal members thought this new offer a trick.

Many Indian families camped near the towns of Burns and Drewsey in tule or gunnysack "wickiups" or lived on their allotment. The men found seasonal work with ranchers. Women washed clothes and made buckskin gloves to trade occasionally for flour, sugar and coffee. After the Edward Hines Lumber Mill opened in 1930, and later when a mill opened near Senaca, there were 


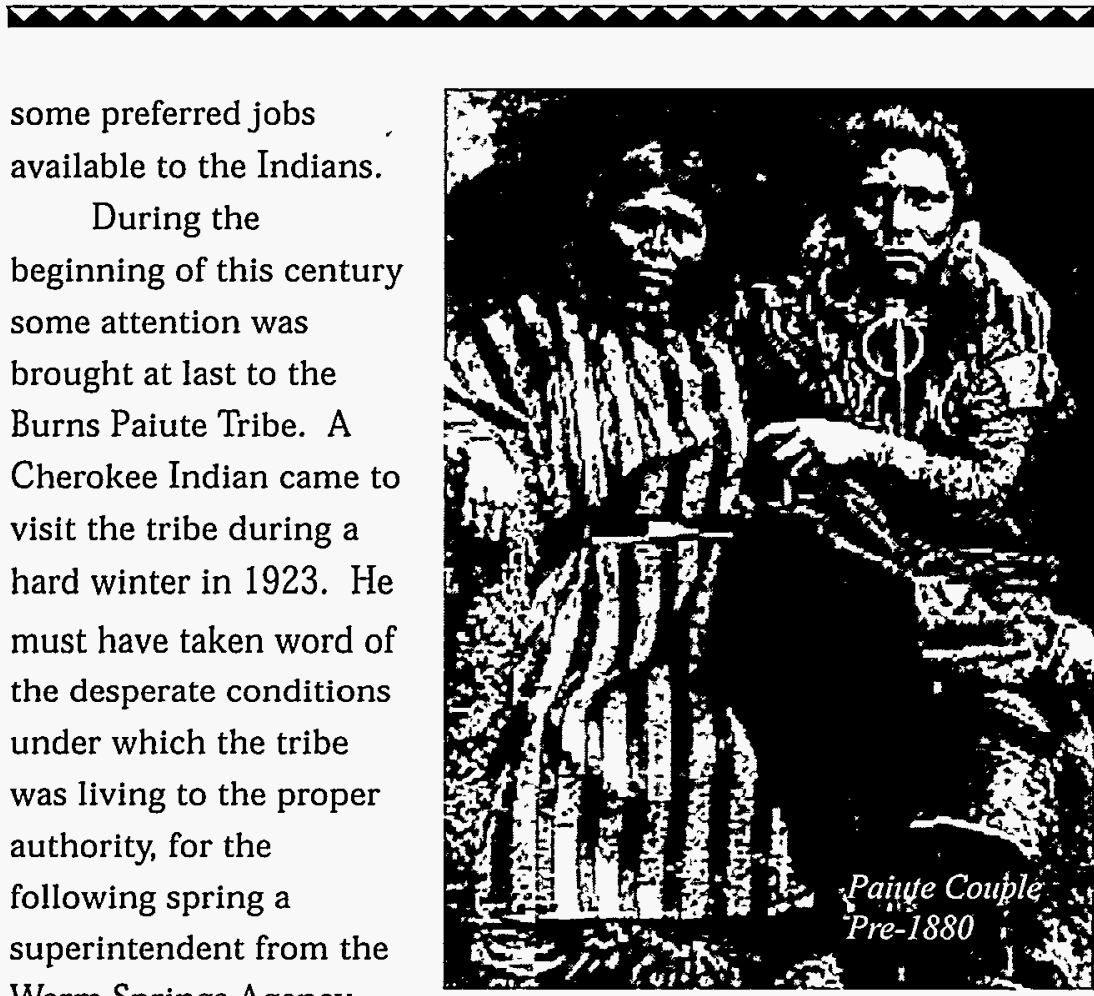

first to meet the spiritual needs of the tribe, came to the area in 1927. Before this the tribe had no Catholic or Christian religious leader. The earliest visit of a priest to the Burns Paiute people was mentioned by Peter Teeman. He said that a Chinese priest, Father Chan, stopped on his way to Canyon City in 1861. Today, many tribal members follow a Christian faith.

Father Heuel was a friend to the Burns Paiute people. He encouraged the tribe to seek payment for the Malheur Reservation that was taken from them without their agreement. The case dragged on for 35 years. In 1969 , after enormous legal fees were subtracted from the total settlement, came to Burns. Soon

after Army tents were brought in and set up where the Burns Cemetery now is. In 1928, the local Egan Land Company gave the Burns Paiute ten acres of land just outside the city of Burns. The land was the old city dump, which the Indians cleaned and drilled a well on to make ready for the houses. Twenty two-room homes and a small school and a community center were built by the Bureau of Indian Affairs. A small church was built by the local Catholic church in 1932. The school, church and community center were moved to the new reservation after it was established.

Schooling was a problem for the tribe. The public school for many years would not accept Indian students for health reasons, since many children had tuberculosis and trachoma. A school opened on the reservation in 1934. However, some families continued to send their children to boarding schools far from home on reservations, such as Fort Bidwell Indian School, Fort Bidwell, California. Health care for the Indians did improve and in 1948 Burns' public schools were finally opened to the Indian children.

Father Heuel, a Catholic priest who was the
850 Paiute received as little as $\$ 741$ each for the loss of their land. This was because the price of the land was set at 1890 prices, approximately .28 to .45 cents per acre.

In 1935, 760 acres of homestead and submarginal land was purchased with a loan provided by the National Industrial Recovery Act. The tribe repaid the loan with money earned from leasing the small arable farmland of the new property. This land is held in trust by the U.S. Government for the Burns Paiute Tribe. In 1938, the Bureau of Indian Affairs built 27 two-bedroom homes on the new land.

Under the Indian Reorganization Act of 1936, tribal elections were held for the first time. This early government consisted of a five-member governing body, elected by position. It was not until 1968, however, that the constitution and bylaws for the tribe were written and approved. This formalized and made operational the current tribal government. The tribe was then able to receive government contracts and grants which are the basis of the tribal administration today. Finally, on October 13, 1972, the Burns Paiute 
were recognized as an independent Indian tribe.

At that time, the 760 acres bought in 1934 plus the 10 original acres of land were established as the Burns Paiute Reservation. The jurisdiction for this reservation was placed in the Bureau of Indian Affairs in Warm Springs, 191 miles northwest of Burns. Individual tribal members still own over 11,000 of allotment lands scattered over four townships east of the reservation. Local ranchers lease these allotments for grazing cattle. Allotment lands are also held federally so that they are exempt from taxes, but unlike the reservation they are within county jurisdiction.

The Constitution and Bylaws of the Burns Paiute Colony, adopted May 16, 1968, delineates the objectives, membership, powers of the General Council and bill of rights of the Burns Paiute Tribe. The constitution and bylaws were revised in 1988, changing the five-member business council to a seven-member tribal council of today. This was necessary to avoid conflict between the two governing bodies, the tribal council and the general council. Now the tribal council is directly responsible to the general council. The constitution and bylaws of the tribe also outlined the format of the governing body, elections and duties of officers. The governing body, or general council, consists of all qualified voters. To qualify to vote one must be a tribal member 18 years of age or older who lives in the reservation, or be an absentee voter. The general council meets twice a year to discuss and vote on important matters.

The standard business of the tribe is conducted by the seven-member tribal council, which includes a chairperson and a vicechairperson. Each member of the tribal council is nominated and elected to a three-year term by the general council. The tribal council meets several times a month, overseeing the tribal government and carrying out the decisions of the general council

The tribal government includes nine

\section{Why Lightning Strikes Juniper}

A mosquito had just come from getting blood from an Indian when Lightening noticed it. Lightening saw the blood on the mosquito and asked where it came from. The mosquito wanted to protect the Indians, so it said that the blood came from the juniper tree. So, this is why lightening always strikes the juniper tree.

departments and various committees. The departments provide essential services to the community and uphold tribal interests when working with state and federal agencies. For example, the Tribal Administration takes care of the day-to-day management and accounting of the tribal government. They also assist in the formation and implementation of plans for community development and the administering of federal and state grants and contracts. The Educational Department, on the other hand, works to help our students of all ages stay in school, while the Health Department provides the community with health care and social services.

Other departments cover such areas as environmental and energy issues, lease compliance for all the allotments and tribal lands, mitigation for fish and wildlife, cultural preservation and enhancement, and law enforcement and maintenance.

Whereas the departments are made up of tribal employees, the committees are small groups of community members appointed by tribal council. These committees advise, oversee and are responsible for some of the important aspects of the tribe's organization. A five-member election committee organizes and runs any elections held and any recalls or initiative called for by the tribe. The incorporated Farmland Board contracts out for hay to be produced on the farmland and puts 
any funds received from the selling of the hay back into supplies and production. The Parent Committee works as an advisory board to the education specialist. There are also committees on culture, housing, social services and the annual Mother's Day Pow Wow, among others. Some tribal members are also involved in committees in the nearby community of Burns.

Tribal members continue to hunt and gather traditional foods. Roots such as camas, bitterroot and biscuitroot are dug in the Spring. In the late summer chokecherries and berries are gathered. People also gather willow and tule for making baskets and cradleboards. Other crafts traditional to the Burns Paiute that are practiced in the community include beadwork and drum-making. The hunting of elk, deer, quail and groundhog as supplemental food sources continue as well.

A yearly celebration and gathering of tribal members and neighboring tribes is the recentlystarted, annual Mother's Day Pow Wow. The Pow Wow includes traditional dancing and drumming, dance contests, a raffle, and crafts and food booths. This is a continuation of a tradition of dance in the community. During the 1950s there was a vigorous boys dance group. Later in the 1960 s and 1970s a girls dance group was active. Another annual festival is Reservation Day on October 13. This was declared a tribal holiday in honor of the day the land held in trust for the tribe became a reservation.

Today there are 281 members of the tribe, less than 37 percent of which reside permanently on the reservation. Both the small numbers and the relatively recent formation of the tribal government and reservation have added challenges and difficulties in starting the economic and social programs that other Oregon tribes already have in place. Nonetheless, the Burns Paiute Tribe is proud of its history and culture. The tribe is currently working to gain a greater understanding of our culture, and to preserve what knowledge we have of our past. All the while, we are looking toward the future and the developing of a stronger, healthier community to pass on to the next generation. 


\section{CoEur D'Alene Tribal Profile}

\section{LOCATION AND LAND BASE:}

Pre-Treaty: Four million acre territory bordered by Clark Fork River in Montana on the east, Clearwater River territories to the south, Spokane Falls to the west, and Lake Pend Oreille to the north. In 1873, an executive order established 592,000 acre reservation. In 1889 , an executive order required the Coeur d'Alene to cede all land except for present reservation, including Harrison, Idaho. In 1894, an agreement changed the northern border of reservation to exclude Harrison. The current reservation includes 27,742 acres of tribal land, 40,718 acres of allotted land, and 276,540 acres of fee land, for a total of 345,000 acres.

\section{TRIBAL POPULATION}

Pre-1855: 3,000 to 4,$000 ; 1997: 1,450$.

\section{LANGUAGE(S)}

dialects of the Salish family. They are closely related to the Flathead, Kalispel, Spokane, and Colville Tribes.

\section{TRIBAL GOVERNMENT}

Treaty times: band and tribe leaders.

Present: A constitution was approved September 2, 1949 and amended in 1960-1961. The constitution was revised November 10,1984, and approved by the Secretary of the Interior, Bureau of Indian Affairs, December 21, 1984. The constitution provides for a general council and seven council members. Council members are elected to threeyear terms. The council delegates authority for implementation of the council's legislative actions to the administrative director.

\section{ECONOMIC BASE}

Tribal Logging Operation

Coeur d'Alene Tribal Farm

Benewah Market

Coeur d'Alene Tribal Bingo-Casino

(Worley, Idaho)

Benewah Medical Center

Benewah Auto Center

Tribal Cut and Saw

Utilities serving reservation: City of Plummer, Kootenai Electric, Clearwater

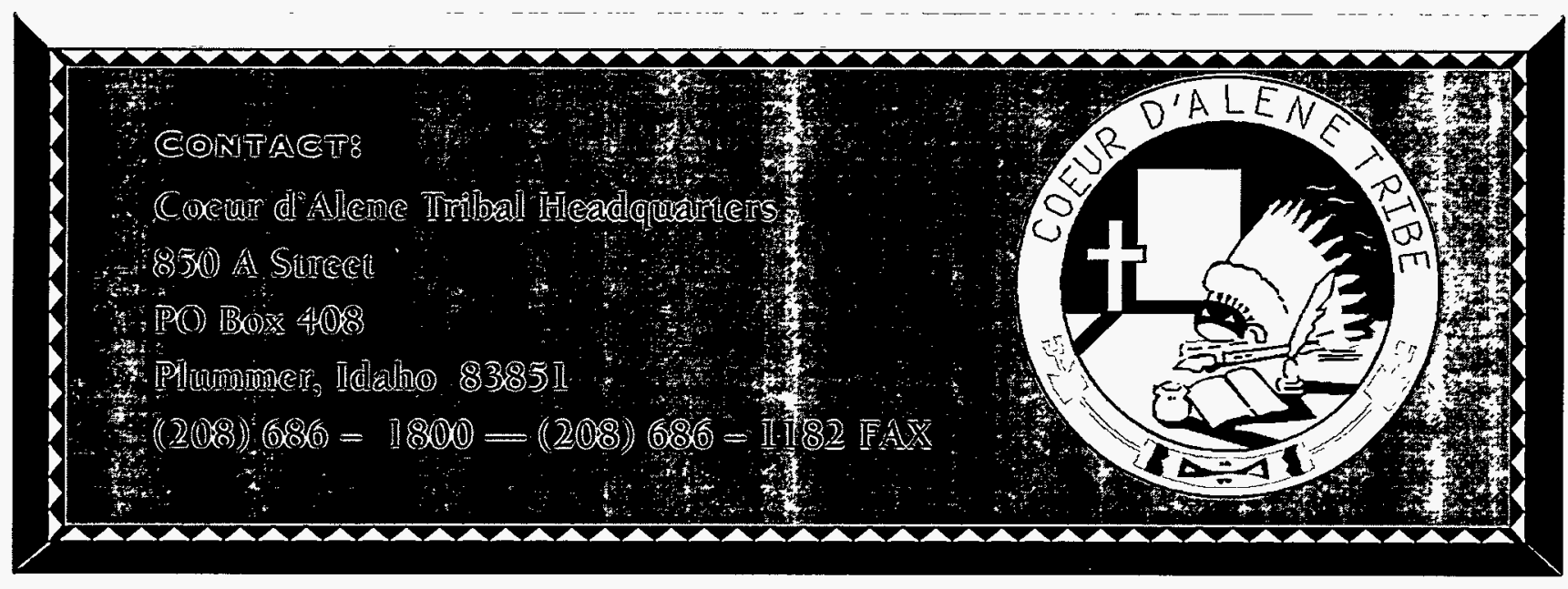




\section{COEUR D'AlENE}

\section{NARRATIVE}

Reno Stensgar is in the fourth grade at the Coeur d'Alene Tribal School. He lives on the Coeur d'Alene Reservation at DeSmet, in northern Idaho, halfway between Moscow and Coeur d'Alene.

He likes being a Coeur d'Alene Indian because he gets to do all the things that everyone else does in northern Idaho. He goes with his family to Coeur d'Alene and Spokane for shopping and movies. In the winter, he skis at Sandpoint, and in the summer, he goes golfing with his dad. His brother, Matt, plays football for Plummer High School, and the family travels all over the Panhandle to watch him play.

As an Indian, he gets to do a lot of things that only Indians can do. He travels a lot, and takes part in ceremonies that have been passed down by the ancestors for hundreds of years.

Today he is going on a trip today with his family - grandma, mom and dad, Matt and

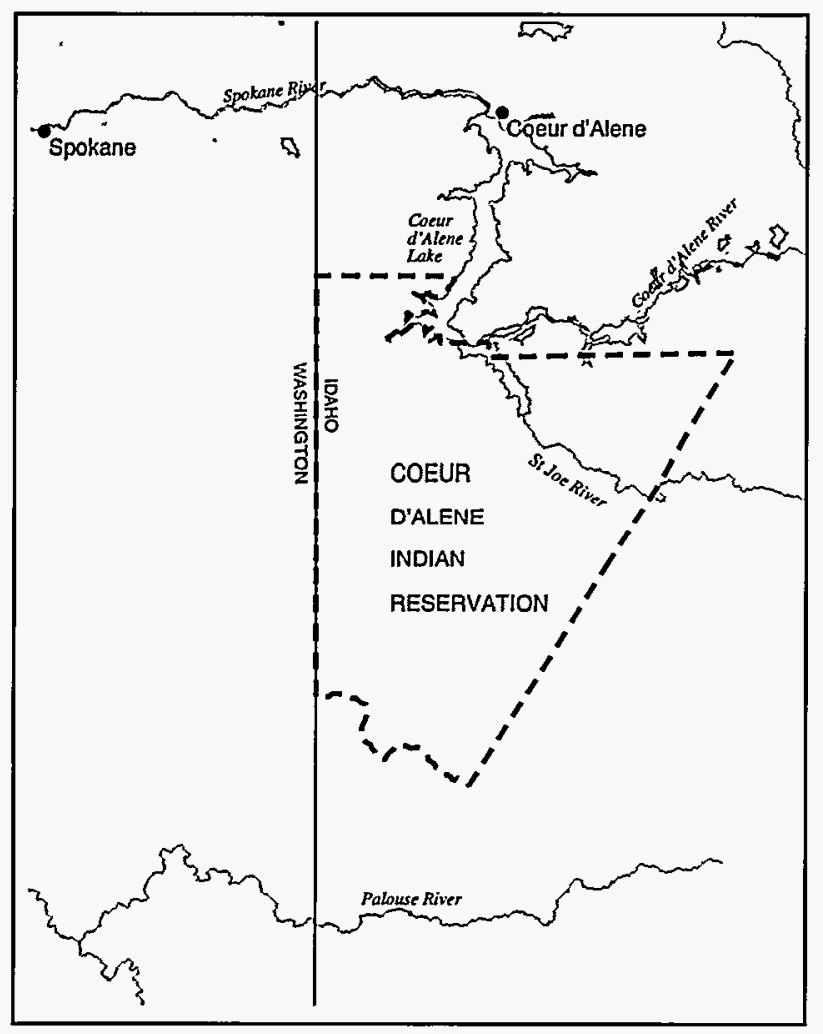

Shirley. The only one not going is his oldest sister, Laura. She's at the University of Washington in Seattle.

The family is packing up to go to the Tribe's famous Old Mission at Cataldo, between Coeur d'Alene and Kellogg. The Tribe goes there for a pilgrimage every year on August 15.

Reno's grandma's real name is Margaret, but he calls her Keena. That's the Indian name for dad's mother. Keena tries to teach Reno Indian words, but he never hears anybody else talking Indian, so he doesn't try very hard to learn.

Keena is always talking about the old days. If Reno listens to her stories, he will know all about the Coeur d'Alene Indians.

Reno hears Keena calling. "Reno, hurry up and get your costume together. Your folks are loading up the van and you have to get all your feathers and beadwork ready for the ceremonies."

He stuffs everything in my suitcase, being careful not to break his eagle feathers. Finally he gets it to the red van, and dad puts his suitcase in the back with all the rest of the family costumes. Keena moves over in the middle seat so Reno can sit next to her. She always tells him stories on their trips.

Finally the family heads out of DeSmet and up the highway. Keena laughs as they drive through Tensed. "The white people started this town," she says, "long after we Indians had settled at DeSmet. The towns are only a mile apart, but they wanted their own post office. They couldn't use the name DeSmet, because we already had it. So they spelled DeSmet backwards, and ended up with Tensed." She chuckles again.

\section{TRAVELING IN THE OLD DAYS}

“We're lucky, Reno," says Keena. "We'll get there in less than two hours today. When I was your age, it took us three days. I always traveled with my grandma, just like you and me. Her Indian name was Hap-shi-neh. 
"We loaded all our stuff in Grandma Hapshineh's rig. A rig is a four-wheeled wagon with two seats, pulled by two horses. We packed everything on the floor of the rig, under the seats. Grandma Hapshineh drove.

"The men and the boys all got to ride horseback. I really liked to ride horseback too. But I always had to start out riding with Hapshineh in her rig. After a couple of miles in the rig, I'd untie my horse from the back and ride the rest of the way with the boys. We raced back and forth on our horses and had lots of fun.

"We had six rigs full of families from DeSmet, and about twenty riders. As we rode north, other rigs and riders joined us from the big Indian farms in Moctelme Valley and Lovell Valley. Everyone hollered greetings back and forth. The riders visited and laughed along the way.

"Other wagons and riders joined us when we got to the big farms around Worley. They were really Spokane and Kalispel Indians there. The Government made them move away from their old homes around Spokane, Sandpoint, and Clark Fork. They had to go to somebody else's reservation in 1895. Our Chief Seltice felt sorry for them, and he invited them to settle here with us. Nowadays, we're all just one big Tribe, and we are all called the Coeur d'Alenes.

"Actually, Reno, we never called ourselves Coeur d'Alenes anyway. That's a French nickname that the fur traders gave our ancestors. Our old people gave the fur traders a hard time. They wouldn't let the traders come around our part of Idaho.

"When they went to trade their furs at Fort Spokane, or Fort Colville, they drove a hard bargain. So the traders called our people Sharppointed Hearts. I guess that's what the French word means.

"The nickname stuck with the white people. They never could pronounce our Indian names anyway. Our old timers called themselves scheechu-umsh. It means the ones that were found

\section{Fisheries Management}

Due to early land use practices, such as land clearing for framing, grazing and logging activities, bull trout and westslope cutthroat trout populations have been greatly reduced in the past 40 years. Both species are native to the reservation and are of historical importance to the Tribe.

The Coeur d'Alene Tribe's fisheries program, which began in January of 1991, has conducted annual hydrologic and biological assessments of four primary streams, and conducted baseline assessments on the other watercourses within the reservation. Additionally, studies have been conducted on that portion of Lake Coeur d'Alene located within the reservation. This information will be used to develop a fisheries management plan and restoration program for the reservation.

Funding for the program comes from two sources: Bonneville Power Administration and Congressional funding contracted through the Bureau of Indian Affairs. The current management strategy for the fisheries program is to restore, protect, enhance and re-establish native fish species into the reservation waters. The fisheries program is moving towards the implementation phase of a stream restoration program, which will involve the Tribe, private land owners, the Federal agencies, and the state of Idaho. In fiscal year 1995, the Tribe plans to begin the implementation phase of the restoration work through development of demonstration projects to show what work can be accomplished to improve habitat.

The Tribe will begin soliciting comments on the improvement program through public involvement throughout the winter of 1995. The improvement program could incorporate several strategies, including restoration of habitats, trout ponds/ water storage facilities, and possibly hatchery supplementation. 
here. Today, the lake and the city and the mountains are all stuck with our old nickname.

"There's the highway sign: Leaving Coeur d'Alene Indian Reservation. In the old days our land went all the way to Lake Pend Oreille and east to Mullan. But the white people found a lot of gold in our mountains and a lot of timber along our rivers. So the government wouldn't let us keep it.

"In our 1889 Treaty, the Government forced our Chiefs to sell all this land around the lake and all the land up into the mountains. The Chiefs were only able to keep the southern part for the reservation. Here's the south fork of Mica Creek. That's where Hapshineh and I used to pull up and camp for the first night on the road. The horseback riders had everything all set up by the time the rigs pulled in. They had the fires all going, so the grandmas could fry up their bread and boil their stew.

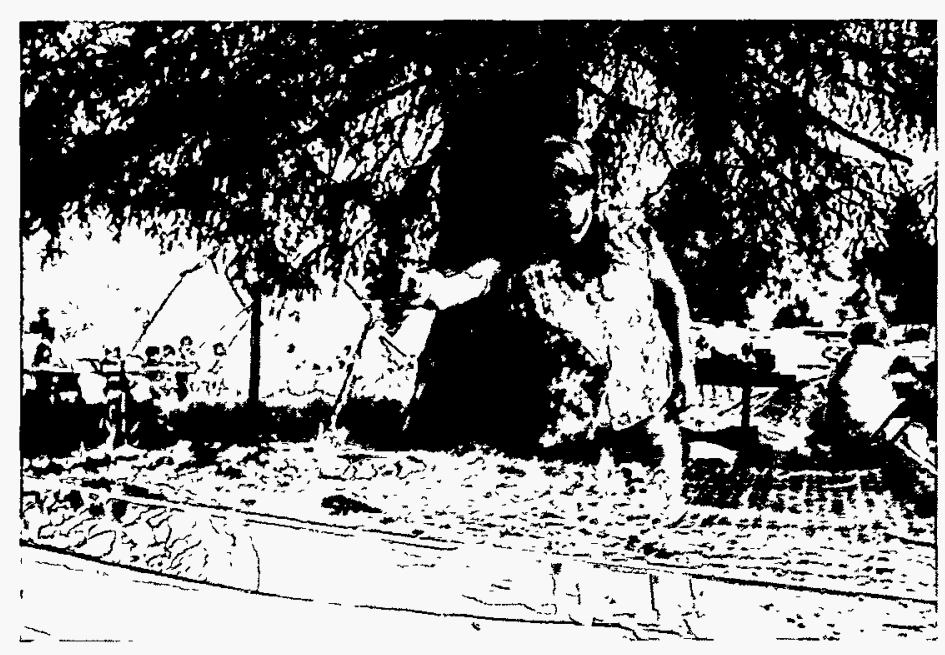

"If the boys were lucky and shot a deer along the way, Hapshineh got all the girls to help cut the meat into long thin strips. The boys had set up an old bedspring over a fire, and Hapshineh threw the strips of meat on the springs.

"None of us waited for dinner to be ready. We didn't even need plates. We grabbed the smoked meat right off the springs, whenever it looked done. Hapshineh speared us fry bread right out of her sizzling pan. Of course, we always had to wait for the old folks to get their food first.

"The second day was always a shorter ride. We just rode as far as Coeur d'Alene and camped along the Spokane River. Our people always camped there. They called it Headwaters, because that is where the Spokane River starts.

"By the time the rigs pulled up at Headwaters, the boys on horseback had usually caught some fish. We kids tied our horses up, and ran right down to swim in the river. Hapshineh fried the fresh fish, while we laughed and splashed around in the cool water. We went up to get some fish when we felt hungry. Before dark, Hapshineh hollered at us down at the river, 'Cherumsh.' That means that it is time to pray. We had to rush back up the beach to the fires in front of the teepees. We all prayed in Indian in those days, and it took a long time for Hapshineh to finish. We couldn't play after that. Hapshineh tucked us into our blankets and we fell asleep listening to the old folks telling stories.

"On the third day, we started out real early in the morning. We said prayers, had breakfast, and helped load all our camping gear under the seats of Hapshineh's rig. I'd sit next to her in the rig all the way along the lake to Wolf Lodge.

"Hapshineh said there were a lot of wolves there in the old days. Sometimes they tied teepee poles across the branches of the trees to make platforms. They slept on these tree platforms to keep away from the wolves. The men had to keep fires going at night, so the wolves wouldn't bother the horses."

\section{SETTING UP CAMP}

'It seems like Keena has been talking for two hours straight,' thinks Reno to himself. By now he sees the big white church on the hill above the freeway. It's shining bright in the sun, surrounded by lawns and trees.

"Hapshineh's folks all helped build the church," brags Keena. "That was back in 1850. It's 
the oldest building in Idaho now. That's why they've made it a State Park. Isn't it beautiful today!"

Reno is busy thinking about all the other kids, and the swimming hole that's just down behind the trees. But he knows he will have to set up camp.

"Don't go running off, Reno," says his dad. "We've got work to do. Help Matt get the teepee poles-thirteen of them. Your mom and I will unload the van. Shirley, you help your grandmother."

A pile of poles is hidden back in the trees. Reno and Matt go there and select four long, matching poles. They watch their dad spread the teepee canvas on the ground.

"Come on, Reno," smiles Matt pushing him forward with a pole. "Put these four poles down

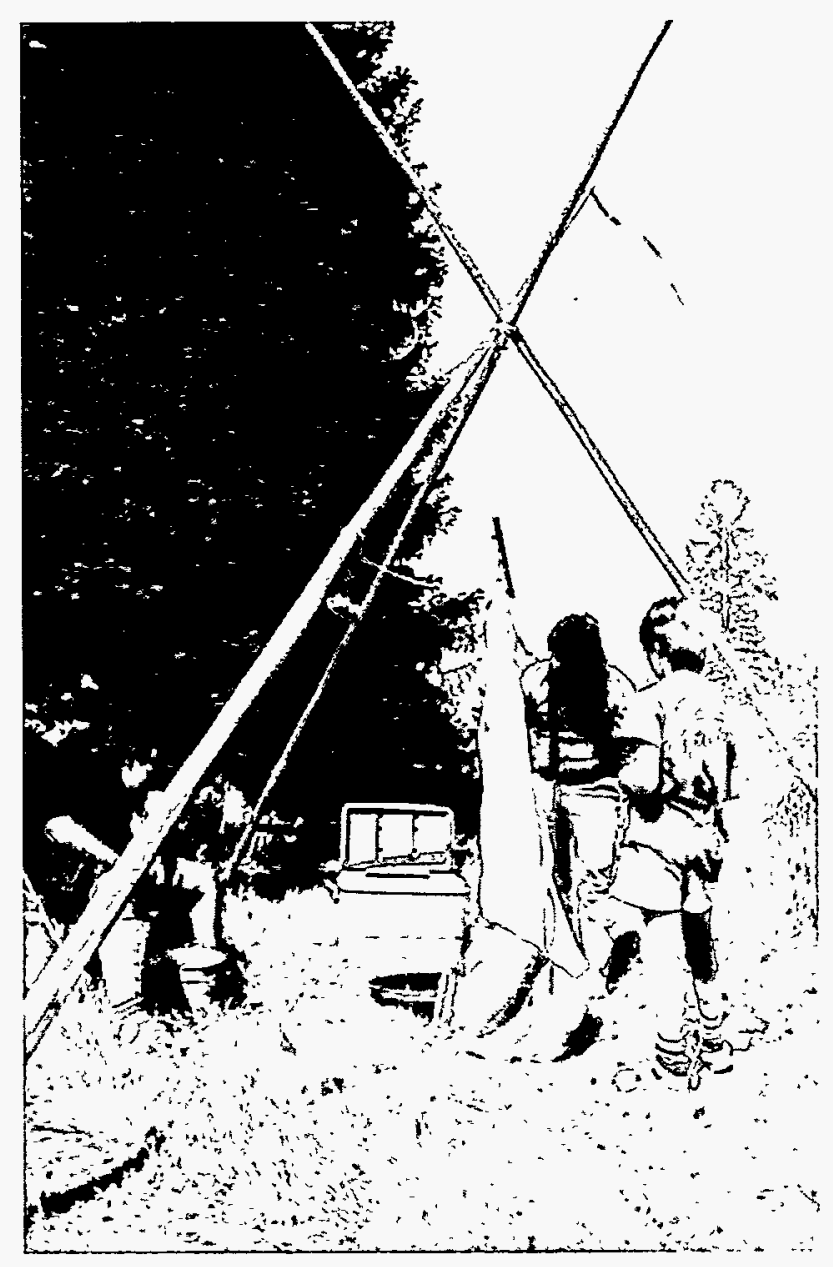

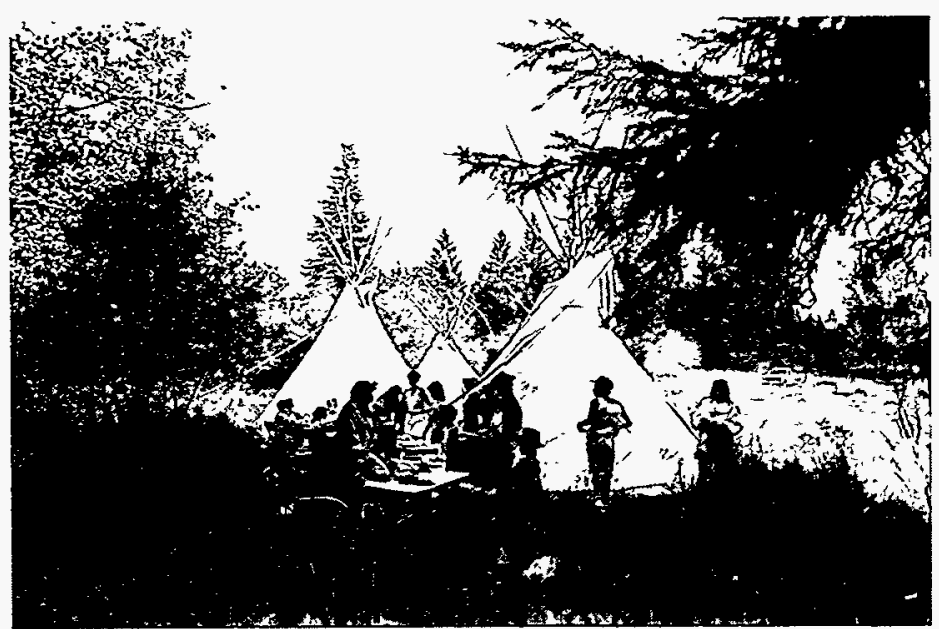

right. Dad has to tie them together, right where the top of the canvas will come."

"Now comes the hard part," says Reno. He helps his dad and brother carry the four poles over to where his mother is pointing. "OK, Matt, let's hold down the bottoms and watch dad struggle."

Their dad strains and pushes with all his might to raise the tops of the poles into the air. "Hurry up and spread them out at the bottom before they fall over again," he shouts.

"That looks good enough," says Reno's mother. "Now get six more poles and fit them in at the top the way your dad tells you. They have to fit tight or the canvas won't reach around."

"Let's see how good you did," says Keena, coming up to watch. "You all have to live together now. Get the last pole up there, with the canvas tied to it. That's right. Lean it right in there, in the back."

'Now it's easy' smiles Reno to himself, while still thinking about swimming. 'Just pull the canvas all the way around. Lace it together in front. Stake the bottom to the ground. Put up two outside poles for the smoke flaps.'

"Are you ready to move in, Keena?" asks Reno with a grin.

"You're lucky," laughs Keena. "If the canvas didn't fit the poles right, you'd have to take it down and start again. Now you can go swimming!" 


\section{Water Resource Programs}

Lake Management Plan, Lake Coeur d'Alene: The Coeur d'Alene Tribe worked in cooperation with the State of Idaho and the US Geological Survey to prepare a management plan for Lake Coeur d'Alene. This plan incorporated data obtained from cores taken from the bed of the lake, as well as assessments of nutrient loading from sedimentation caused by soil erosion, failed sewage systems and aquatic plant growth within the system.

The lake has been adversely impacted by residential development, mining, logging, farming, and grazing activities. In addition, numerous sewer systems are either deteriorated or are at the point of overcapacity. Thus, nutrient loading has been an issue of concern. Based on radioactive dating of the cores taken from the bed, coupled with the presence of the ash layer from the eruption of Mt. St. Helens in 1980, it has been possible to determine that sedimentation of some of the nearshore areas is occurring at the rate of one inch per year.

The cooperative activities of the agencies and the public in the development of the management plan should allow for implementation of 'Best Management Practices' within the lake basin.

Section 106, Water Quality: The Coeur d'Alene Tribe has spent the past three years developing the information necessary for preparing water quality standards applicable to the reservation waterbodies. The purpose is to give the Tribe water standards and criteria to begin systematic clean-up and maintenance of the Tribe's water. The foundation of the standards is a stream classification system, designated uses for those classes, criteria to protect those uses and an anti-degradation policy to prevent future pollution.

Clean water is becoming a very valuable commodity. While economic activities are necessary for the well-being of the Coeur d'Alene Tribe and its membership, as well as the non-Indian community, it is also important to develop the means to protect the water resources. The implementation of any fisheries improvement project, lake management plan or recreational development requires a change in how business is being conducted. Thus, under the authority of the Clean Water Act, the Coeur d'Alene Tribe will develop the required water standards applicable to the reservation.

For Reno, the time was flying. He and Shirley and their cousins were diving and shouting in the Coeur d'Alene River. They were grabbing mud from the bank, and throwing mud balls at each other. Then they'd dive some more, and swim under water to get rid of the mud.

Looking up at the red clouds overhead, Reno said, "Oh, oh, we're late!" The cousins start running through the woods streaming water and mud back to camp.

A lot of the teepees are up now. They stretch out along the trees at the bottom of the mission hill. Reno sees his mom's teepee right away. It has red circles painted on top. Everyone else is sitting around eating.
"It's about time," complains their mother. "Hurry up and eat now!" She throws a sweatshirt at Reno to wear. Then she gets him a hamburger off the propane camp stove. She tosses him a sack of potato chips. "There's fruit and pop in the ice chest."

"Reno, you sit down here," calls out Keena. She leans back comfortably in her folding aluminum camp chair. She pulls a bright, warm Pendleton blanket over her lap.

"When I was your age, the old folks were always telling stories in Indian. But we were too busy playing around, and we didn't listen. So you listen now. I'm going to tell you something about Coyote and that river out there." 


\section{KeENA TELLS INDIAN STORIES}

"In the old days, most of the northwest Tribes had salmon in their rivers," said Keena. "That was before they built Coulee Dam and stopped all the salmon. But we Coeur d'Alenes never did have salmon in our rivers."

"Why not?" asks Reno.

"The old folks said it was because of Coyote," laughs Keena. "Coyote was something like God's helper, to make the world a good place for the Indians.

"Coyote killed monsters that ate people. He brought salmon up the Columbia River, into the rivers where the different Tribes lived. He also brought fire, so the people could cook the salmon.

\section{Sometimes}

Coyote even broke up waterfalls that were too high for the salmon to jump.

"Coyote was pretty goofy too. Before he brought

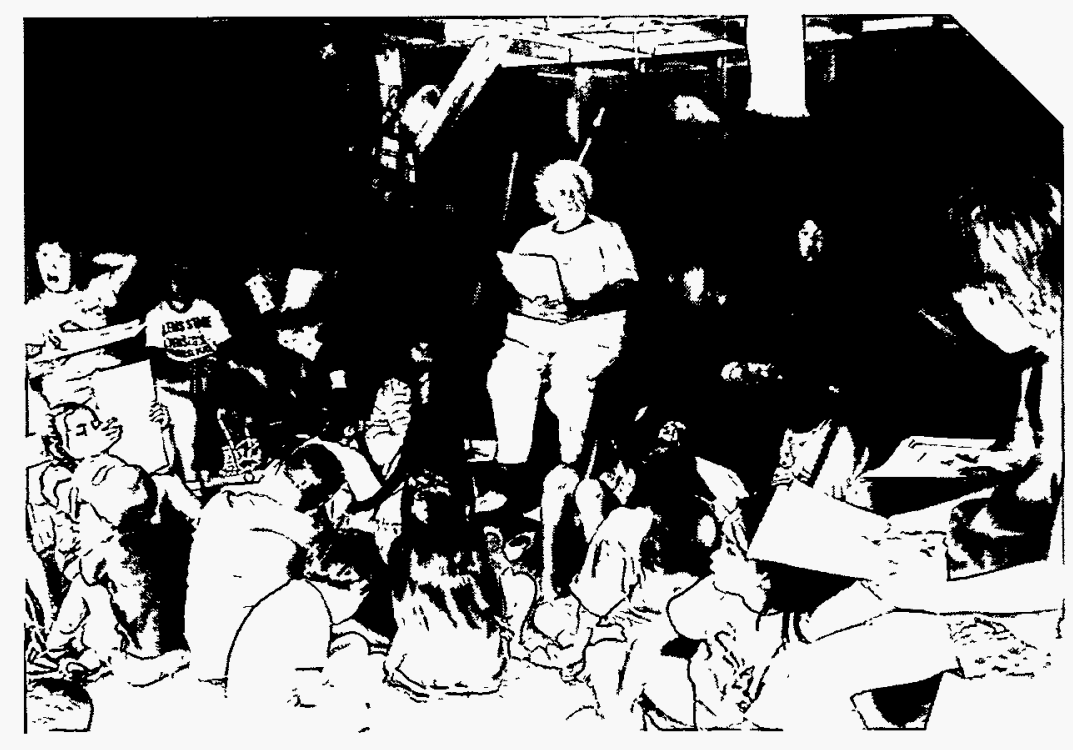
salmon to a Tribe, he always asked the Chief's daughter to be his wife. Most of the Tribes gave Coyote a beautiful girl, so they could get salmon in their rivers.

"In those days, all the animals and people were the same. We knew they were animals, but they acted just like people. We learned a lot of lessons from the way animals act.

"One day, Coyote came up to Lake Coeur d'Alene to visit our Chief. He said, 'You Coeur d'Alenes are pitiful. It's too bad you don't have salmon like the other Tribes. But the falls at Spokane are too high. They can't jump over the falls to swim up to your rivers.
"'However, there is a deep canyon that goes part way around the falls. If you give me your daughter for my wife, I will dig out the canyon all the way around the falls. Then I will bring salmon around the falls and up to your lake. From the lake, they can swim easily up your two big rivers towards the mountains.'

"I don't know about that,' said the Chief. 'We Coeur d'Alenes don't give our women away to just anyone. I'll have to think that over.'

"Coyote saw that the Chief's daughter was very beautiful. He told the Chief, 'Alright, you think it over, and I'll go back and do some more digging so you can have salmon.' Coyote was thinking about the Chief's daughter, and he dug really hard. He circled around where downtown Spokane is today. Then he started digging back towards the river. "When he came back to see the Chief, Coyote was sure the Chief would fall for his plan. But the Chief said, 'No, Coyote, I've decided not to give up my daughter to be your wife.' Coyote teased the Chief about not having salmon. But the Chief would not change his mind.

"So Coyote got mad and went away. $\mathrm{He}$ refused to finish digging the ditch around Spokane Falls. That's why we Coeur d'Alenes didn't ever have salmon in our rivers.

"There's some truth to that story, Reno," laughs Keena. "I guess the Coeur d'Alenes were stingy with their women. The old Chiefs would never let them marry fur traders or other white 
men. A lot of women from other Tribes married traders, but the Coeur d'Alenes never did. We were all full-blooded Indians when I was your age.

"We did have to travel to get our salmon. Hapshineh's family used to leave their village at Hayden Lake and ride horseback down to Spokane Valley. They joined other Coeur d'Alenes from the valley and from Liberty Lake. They all went down to the falls. There they had to fish with the Spokane Indians.

"They said that the salmon were so thick below the falls, you could almost walk across the river on their backs. More swam up Hangman Creek and the Little Spokane River. But a lot kept trying to jump Spokane Falls. It was easy to net them or just hook them right out of the water. Hapshineh said that salmon were always a special treat.

"She also said that there used to be a ravine in Spokane. It started in Peaceful Valley and circled around. But the white people filled it in, when they built the city there.

"Reno, see how easy you folks have it today. You just jump in the car and go the supermarket. Hapshineh and her folks had to travel a long way for their food. They chased the deer down from the hills. They paddled out to catch the fish. They rode longs ways to dig roots and bulbs in the summer, and to pick huckleberries in the mountains.

"Only the real old people and some of the children stayed in the villages all summer. Everyone else was traveling and harvesting all the things that God put there for them. They ate all the fresh food they needed. Then they filled up baskets and leather bags with dried food for the winter."

\section{DEER Hunting}

"In the old days, the people had good ways to hunt deer," says Keena, smiling at Reno. "They didn't just ride around the back roads in a pickup, like some of your friends do today.
"Hapshineh said that they all had to work together on a deer drive. The leader of the hunt had special powers to know all about deer. $\mathrm{He}$ picked out the right day and sent the hunters up into the hills to begin a drive down the hills into a valley.

"While the hunters were gone, the leader took a sack of old moccasins that the women had cut up and burned around the edges. He went around in a big circle across the bottom of the valley and tied a piece of burnt buckskin on every tree. The deer didn't like the smell of burnt moccasins and wouldn't go past the trees.

"When the hunters started down the mountain, all the deer ran ahead of them. When the hunters got to the bottom of the valley, the deer were all there, running back and forth inside the big circle of burnt moccasins. It was easy to kill enough deer to feed the whole village.

"On other deer drives, the leader and hunters drove deer down from the hills into the lake or river. Some of the men were hiding along the banks in dugout canoes. When the deer got into the water to swim away, it was easy for the hunters to chase them down in their canoes. They'd just hit the deer in the head with a paddle and tow them to shore.

"After these deer drives, the hunters brought all the deer meat to the leader's teepee. There, it was divided up and passed out evenly to all the families. This was an easy way to feed all the people in the different villages."

\section{BUfFALO HUNTING}

"I missed the most exciting hunting trips," says Keena with a sparkle in her eye. "Hapshineh used to talk about her menfolk going all the way to Montana to hunt buffalo. Those were the days!

"The Coeur d'Alenes had gotten horses from the Nez Perce down south. Some had pretty big herds, long before they ever saw any white men. They only got rifles after the fur traders came. That's when they got serious about buffalo hunting. 


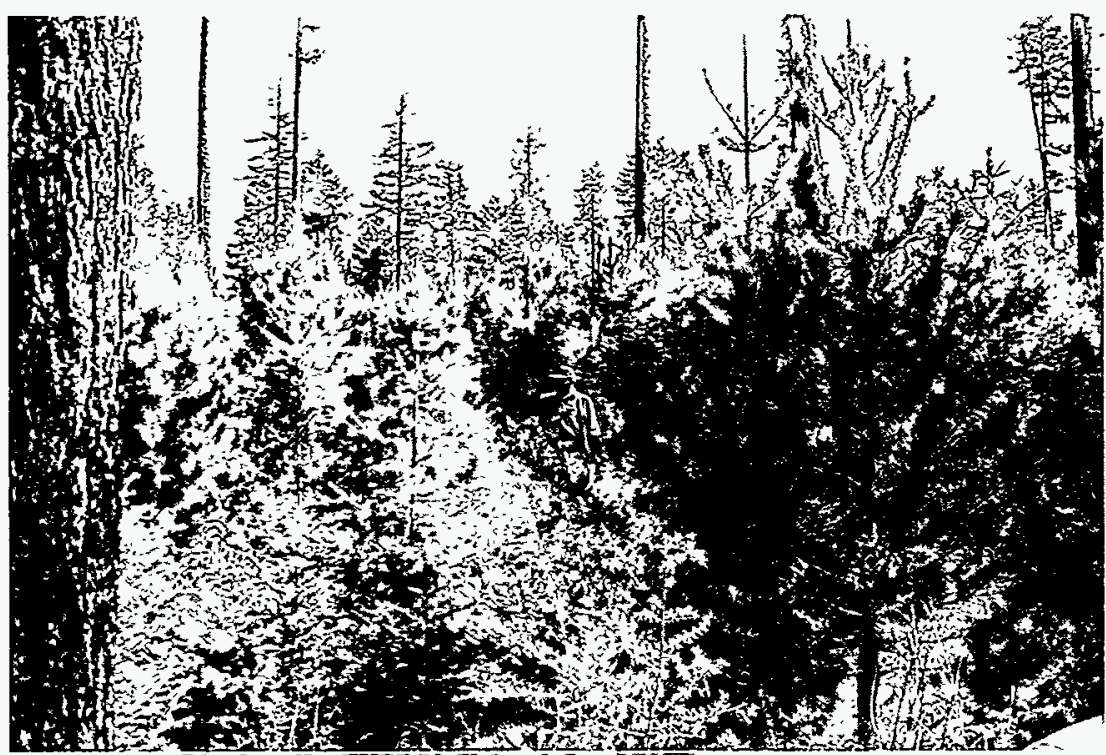

protection of water, cultural, and fisheries concerns.

Timber is sold using open market advertisements to insure the receipts of the highest stumpage values for the Indian owner. In addition, small volume sales are sold to individual Indian land owners. Salvage sales to remove trees killed by insect attacks or fire are also sold on a competitive basis. The forestry program conducts tree planting, thinning, and cone collection activities to improve the health of the Indian forest lands. Prescribed burning is conducted in the fall to reduce fuel loading in the forest, as is the burning of slash resulting from logging operations. The Coeur d'Alene Tribe is a member of the Inland Empire Tree Improvement Cooperative, which works to produce improved seed sources for use in the forests.

\section{Forestry Program}

The Coeur d'Alene Tribe is responsible for forest management on 26,630 acres of Indian timber lands within the Reservation. The activities related to this program include the preparation of environmental assessments, silvicultural prescriptions, and the writing of timber sale contracts associated with the management of the annual cut of 7,200,000 board-feet of timber. The forest resources are managed on a sustained yield policy, which also required
"Hapshineh said that her dad, Chief Vincent, used to go with the older men. About eighty of them with their string wives and oldest children, got together every fall. Each adult had an extra riding horse and two pack horses. Think of that 300 horses strung out for a mile along the trail to Sandpoint!

"At the river crossing camp, they always met up with hunters from other Tribes. Spokanes, Kalispels, and Colvilles joined our folks. They had an easy ride along the Clark Fork River into Montana, without having to go over the mountains. Along the way, they killed a few deer and caught some fish. They enjoyed visiting all the other Indians they met at camps along the river.

"When they got to Missoula, they met Flathead hunters. By the time they headed east into the mountains, they had over 300 people and 
"Our ancestors had to travel about 500 miles from home for the good hunting. It took them about two weeks to travel all the way through the mountains to Helena and Great Falls.

"Hapshineh said there were thousands of buffalo, ranging in big herds for miles. They fed on the tall prairie grass. It grew waist high, before settlers moved in and plowed it all up.

"It was dangerous to hunt buffalo. The hunters had to ride up to the edge of the herd and shoot the biggest animals. Sometimes a wounded buffalo would turn, and he'd make an angry charge against the hunter. You had to be really fast to get away from the horns of an angry buffalo.

"When a buffalo went down, each hunter marked his kill. Then the women came out and butchered the buffalo on the spot. They loaded the big pieces of meat on their horses and took them back to camp.

"The men kept hunting and looking out for the Blackfeet, while the women did all the work on the meat and hides. After they sharpened their knives, everyone rushed out to help cut the meat into long, thin strips. They'd hang the meat up on racks to dry in the sun. Sometimes they built fires and smoked it. Usually they pounded the dry meat into chunky powder, so they could pack it in baskets and big skin pouches. Then the women stretched out the hides. They staked them down on the ground, to be dried by the sun.

"They liked to hunt just before winter. By then the buffalo were growing long, shaggy, thick hair for the winter. These winter hides made really warm robes for winter clothing and blankets.

"Hapshineh said her folks kept hunting until it started to snow. They had to get back through the passes, before they got snowed in.

"It must have been really exciting, when the hunters and all the horses came riding in through the snow. They'd shoot off their guns as they got close to the village at Hayden Lake. They called it Huntaken in those days. Everyone rushed out of the warm snug teepees. They wanted to see all their relatives and the pack horses loaded down with meat and hides.

"It was so good to have all the families together again! The hunters had lots of exciting stories to tell around the fires at night. They feasted on buffalo and boiled roots and dried berries. You could hear the men singing Indian songs and telling stories all night.

"Hapshineh never did go herself. I guess she was too young. She said the men sure missed the old days, after they stopped going for buffalo. She said that their last trip was in 1864 .

"By then, all the people were learning new ways," continues Keena. "They were growing wheat and raising cattle. Hapshineh told me that the old Coeur d'Alenes really liked baking bread with their own wheat flour. It was easier butchering cattle than riding to Montana for buffalo.

"After the Cataldo Mission got going, the Fathers taught the people a lot about farming and ranching. Some of the boys learned by going to school and working right here on the big mission farm. The people liked it, and they learned really fast. They liked making log cabins with stone fireplaces for the winter. I wonder if old Circling Raven had any idea so many changes would come so fast," Keena thinks out loud.

\section{Circling Raven - The Oldest Chief}

"Who was Circling Raven?" asks Reno.

"He was one of your ancestors," replies Keena. "Some say he was Chief for 100 years. That was as far back as anyone can remember. He had strong power to get along with the animals and the birds.

"They say he could talk to the ravens. He would sing Indian songs to the raven. Then his mind would just seem to go blank. A raven would circle over his head, and would talk to him.

"Sometimes in Montana, a raven would circle and tell him where to find the buffalo herds. Other times, a raven warned him when the Blackfeet were sneaking in to attack the camp. 
"One day, a raven told him that men wearing black robes would come someday. These Blackrobes would bring spiritual power and teachings to the people.

"Circling Raven died long before his vision came true. But the people always remembered his words.

"Finally, in 1842, a missionary named Father DeSmet came through with some Flathead Indians. He was wearing black robes, so the people were all excited. Hapshineh's dad was alive then. He used to tell stories about how the people all came together in the Chief's village at Headwaters.

"Hapshineh had an old aunt named Louise Siuwheem. She helped bring all the people together. She was related to the Chief, and was really a powerful woman. She told them that Father DeSmet was the answer to Circling Raven's vision. Since she could also speak Flathead, she translated the Blackrobe's prayers and songs into the Coeur d'Alene's language."

\section{BUILDING THE OLD MISSION}

"Father DeSmet sent other Blackrobes that year, and they built a couple of small churches in other places. But then they moved away and lost what they built. Father Ravalli came from the Flathead Mission, and brought plans for the church. Brother Huet taught the Indians how to carpenter. Our people did all the work themselves. They had no idea you could build anything so big.

"Every morning Brother Huet cooked up a great big pot of mush. He gave everyone a bowlful for working on the church. Hapshineh and her folks worked, off and on, for about five years on the church. She used to tell us about going to the mountain and carrying big rocks on her back for the foundation.

"All the men were busy with axes, squaring logs into huge timbers. At first, they didn't have boards for the walls. Brother had them drill holes in the sides of the huge upright timbers. Then they put poles through, where the walls were supposed to be. They cut tall grass from the fields and braided it solid between the poles. Other Indians hauled clay and mud up from the river, and plastered it thick over the braided grass. That's all the walls they had for a few years.

“They didn't have any nails in those days. The whole church is put together with wooden pegs. But later on, they got boards and nails. So they put on real siding and made the church look like it does today."

\section{MOVING AWAY FROM THE OLD MISSION}

Turning away from Keena, Reno looks up the hill. He sees the tall mission in the floodlights shining white against the dark sky. He looks back at the teepees down below, scattered along the dark trees. It's almost as if he's back in the old days, living in the stories he is hearing.

"Where did all the Indians go, Keena?" he asks.

"The people had been isolated here, and they lived a good life in the old Indian way. But too many white people started coming around, and they crowded out the Indians. In 1862, the Army built the Mullan Road over the mountains from Montana to Walla Walla. It came down from the mountains right here at our mission.

"Hundreds of covered wagons started working their way west. They wanted to build farms on our beautiful prairies and root digging grounds. They were really exhausted, when they finally got all their wagons and oxen down the steep mountain trail. They stopped here at our mission to rest. Their cattle had to feed on our tall, green grass.

"Then, in the 1870s, the miners started swarming all through here. They came up from the gold fields around Boise and Orofino. They were sure that we Indians had gold in our mountains around Wallace.

"A lot of white people were coming in from all over the country. They caused a lot of trouble, 
thinking they could just take everything they wanted.

"Our Chiefs were scared that the white people would run them out of everything they had. So the Chiefs and the missionaries looked all over our Coeur d'Alene country. They wanted to find a place where they could have their own farms, and wouldn't be bothered by all the miners and settlers. The government still wouldn't sign a treaty to allow us a reservation of our own.

"In 1878, the missionaries started building a new church and schools south of the lake at DeSmet. There was a lot of good farmland there, and no homesteaders had moved in. All the people had come together there to dig camas bulbs in the summer, but no one ever really lived there before. In Indian, they called the camas field 'opening in the woods.'

"The family groups that always lived around Cataldo were really sad to leave. Lots of families from Spokane Valley didn't want to leave either. They had grass lands there along the Spokane River to pasture their herds of cattle and horses all winter long. They also had big barns and cabins they didn't want to leave behind.

"But white people had started taking over the Spokane valley too. So gradually, all the families began moving in around the new mission and schools at DeSmet.

"So that's why nobody lives here at Cataldo anymore. That's why our big mission church sits here so lonesome all by itself. But what's really important, is that we keep coming back. We keep remembering our old timers. We keep their history alive. Don't ever forget who you are, Reno."

\section{CEREMONIES AT THE OLd MISSION}

Reno wakes up from his buffalo hunting dreams and hears his mother frying bacon on the Coleman stove.

With a full stomach, Reno heads to the van to get his costume. He hears his bells jingle inside, as he wrestles his suitcase out of the back. He sees the other Coeur d'Alenes coming out in costume, and knows he has to hurry.

Inside the teepee, he strips off his shirt and pants. He pulls on his bright blue shirt, decorated with red ribbons sewed to the front and back. Next he buckles on his beaded front apron piece. He pulls out his buckskin moccasins and ties them tight. Next comes the leather strips with big sleigh bells that go around his legs. He pulls out the beaded hangings to go around his neck. Then comes the headpiece of porcupine hair that he attaches to the top of his head.

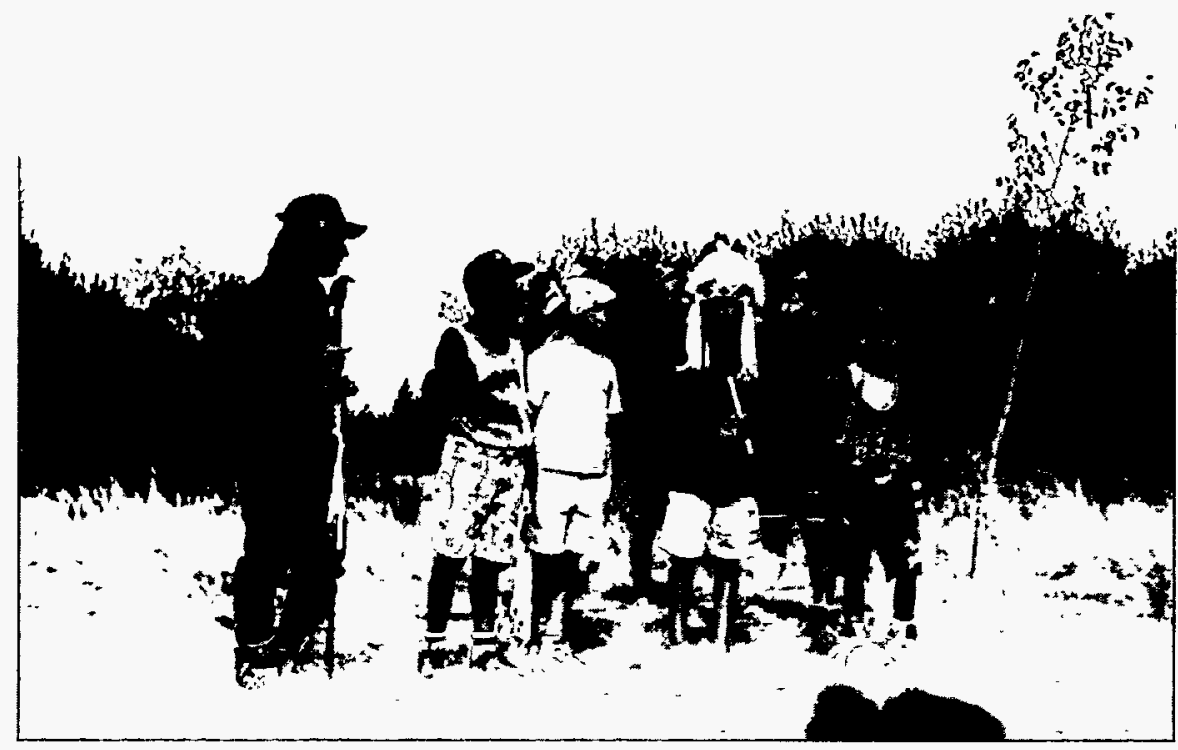
He ties it with buckskin laces under his chin. Last of all, he unfolds his two bustles circles of eagle feathers. He ties one behind his waist and the other one behind his shoulders. He grabs his eagle wing fan, and pushes back the teepee door.

By now the procession is ready. Four men in bright ribbon shirts carry the drum, and begin to sing an old Indian parade song. Reno's partner, Tommy, is carrying the Indian 
flag - a pole with twelve eagle feathers flying from it. Reno's dad hands him the tall cross. "Get up there with Tommy," he says. "The two of you lead the drum up the hill to the cemetery."

Hundreds of tourists have come to watch. They snap a lot of pictures of the boys and the drummers. Behind them, all the Coeur d'Alenes join the procession up the hill. The song fills the air. Flags and banners flutter in the breeze, behind the drum.

Reno and Tommy lead the procession into the old Indian cemetery. They line up behind the beautiful, historical monument of the Tribe's saintly grandmother, Louise Siuwheem. Reno remembers that she was a distant ancestor who helped lead all the Coeur d'Alenes to Christianity. Then she died and was buried her in 1853 .

Everyone lines up behind Reno and Tommy. The song stops, and the missionaries and the Bishop of Boise step up to pray. "Bless these ancestors in heaven, Oh God," prays the Bishop of Boise. "And keep us always faithful to their memory." Reno joins the people in their "Amen."

As the drum song begins again, Reno and Tommy lead the people on up to the church built by their ancestors. After 140 years, it still gives them a feeling of awesome power. The tourists are hushed too, as the procession moves forward over the hand-hewn planks, held by ancient wooden pegs.

Then suddenly an Indian hymn swells up throughout the church. High voices call down God's blessing in ancient words, echoing the singing of the ancestors.

After the hymn, Reno watches Tommy's dad and uncle get up to read from the Bible. They're wearing old costumes, passed down in their family. Then the Bishop talks to the people and leads prayers.

Reno sees the drummers pick up their drum sticks. He knows its time for their cup dance. This song was always used to give thanks for food. Now Tommy, Reno, and Matt move out in front of the altar. They will dance to thank God for the Communion - the body of Jesus that people receive at the altar.

While the drummers sing the first part of the song, Reno and his partners kneel before the altar on one knee. Then the beat changes. The boys stand and begin to dance towards the altar. They hold their eagle feathers high to give thanks and praise to God. Their dance-bells join in with the beat of the drum, as they dance forward and then back again.

The third time Reno gets up from his knees, he knows its time to dance around the altar. The drum changes again. They circle around the altar, eagle feathers high in the air. Reno is nervous. Matt and Tommy have been doing this ceremony for years, but he just started this year. Since he's the shortest, they put him in the middle where he can't make mistakes. He's glad when it's over; but he's proud to be there with his brother.

Reno sits down again, careful not to sit on his eagle feathers. He looks over at his sister, Shirley. After a few minutes, a white-haired old timer gets up. He wears a traditional red mission sash, and turns around to face the people.

That's Shirley's sign to get up. She is short too, so she moves between the other two girls. They all wear beautiful Indian dresses made by their mothers. The old man sings out in his deep voice, "Our Father, Who art in heaven...." The girls' arms move up in the graceful gestures of the Indian sign language.

Keena has told Reno that the old time Indians used these signs when they traveled among strange Tribes. No one uses signs anymore. They all know English. But the Our Father signs are special. Reno has seen them used in ceremonies by a lot of Tribes.

Reno and Tommy, carrying the cross and the eagle flag, turn around to lead everyone out of church. It's hard to get out now, because the church is packed with tourists. They're standing 
all around the walls, and over the front porch. Reno smiles for the cameras. It seems as if every tourist wants to take his picture.

Reno can see the dinner tables set up down the hill by the teepees. He wants to run, but knows his dad will holler at him. So he just walks as fast as he can. He wants to take off his bells and feathers, so he can eat.

Hundreds of visitors were lining up by the tables to get their dumplings and fry bread and smoked deer meat. Reno hears the old warning from Keena. "Don't go rushing into line. Let the elders get their food first. You know our Indian ways is to honor our guests."

By the time everyone has finished eating, Reno is busy running around camp with the other kids. But the men are already sitting around the drum. He hears them warming up, drumming softly and humming their first song.

\section{INDIAN DANCING}

An elder in an eagle feather war bonnet steps to the microphone. He invites the people to move up on the grassy slope and watch the ceremonial dancing. Looking to the teepee, Reno sees Keena waving at him. "Come here, Reno. Let's get ready!"

Inside the teepee, Reno's mother has on her beaded buckskin dress. His father has on his black ribbon shirt and his black blanket pants. His mother is attaching the porcupine hair headdress to his dad's head. He gives her the two eagle feathers to stand up straight on the top. Shirley is already dressed. Matthew is just going out, with his bright red ribbon-shirt and double eaglefeather bustle. When they are all dressed the family stands together.

The master of ceremonies is still talking. "We're not here today just to put on a show. We are commemorating our ancestors who gathered on these grounds. They lived their lives here. They worshipped God here. We come today to unite ourselves with them. We keep faith with them. We walk in the moccasin tracks. We stand today by the good things they passed down to us.

"We dance for our ancestors, for ourselves, and for our children - that our children will always walk a good path, and always enjoy the things that we have enjoyed.

"So, you tourists, we invite you to share with us today. Share our history. Share our hopes for ourselves and for our children.

"Drummers, take it away!"

The lead singer starts the first part of the song. Reno bounces his heel to shake his bells with the drum. When all the singers join in, Reno's dad leads the whole family out in the grassy clearing. All the other families are there too. They have come from DeSmet, from Plummer and from Worley. There are friends from Montana and Washington dancing too.

As Reno is making his first round, his Keena dances up beside him. "Dance proudly, my grandson, like the old timers. Think of them coming back from the buffalo hunt in Montana. They were giving thanks for all the meat they brought over the mountains for their children.

"They were honoring those who were brave against the Blackfeet. They were honoring the courageous hunters who faced the fierce buffalo. So be proud, my grandson!"

Reno is feeling good. 'I am proud,' he thinks. 'Proud to come from a long line of hunters and warriors and Chiefs.' Soon the singing, the drumming, and the sounds of the bells fills his whole body. He isn't thinking anymore. He seems to float with the sound of the drum song and with the spirit of his people. He is dancing, song after song, hardly even seeing the tourists on the grassy slope.

The announcer keeps calling for different kinds of dances. Some dances remember with pride and bravery. Some dances imitate the actions of birds and animals that the people used to hunt.

Keena used to tell Reno all about the dances. She has said that the people lived and felt really 
close to the animals and birds that provided them with food. Dances imitated the animals in order to keep this bond of brotherhood between all creatures.

Keena has told him that all the costumes had some parts of animals or birds - feathers, skins, shells, porcupine hair, deer hooves. This was to remember the times when all of nature lived together as one.

Meanwhile, the sun is slipping across the sky. The announcer is calling for the farewell song. "Thank you for coming," he says. "We hope to see all of you here again next year. It's time to say goodby to the Old Mission, and to all the ancestors buried here!"

Reno dances slow to this song. Everybody is out dancing now. He remembers Keena telling him how people used to shake hands. They always hoped to see each other again, the next time they all came together.

\section{THE TRIBE'S OFFICES}

The family's van pulls up in front of the modern tribal office building and Reno jumps out with his dad. 'I'm really proud of my dad,' thinks Reno. 'He's Chairman of the Tribe and involved in everything. It gives him a headache sometimes. It seems he always has to travel around to big Indian meetings. He has to meet with the big shots in Boise and Washington, DC. But he always brings us back presents. So I think it's pretty good.'

While his dad unlocks the door of the Chairman's office, Reno runs into the Tribal Council Meeting Room. He likes to sit in his dad's leather chair. It's in the middle of the long table

\section{Land Services Program}

The Coeur d'Alene Tribe contracted with the Bureau of Indian Affairs Land Operations and Realty programs in December of 1992. The resulting Land Services Program became part of the overall Coeur d'Alene Tribal Natural Resources Department, and currently consists of offices of Realty/Leasing, Conservation Compliance, Pesticide Enforcement, Noxious Weeds, Air Quality/ Smoke Management, Probates/Records, and Land Acquisition.

The Department, realizing the need for an integrated resource management approach to protect tribal resources, has initiated a coordinated effort to prepare individual resource management plans that effectively address management activities among air, land, water, wildlife, and social uses of the environment.

The Realty/Leasing and Conservation programs work cooperatively with the US Department of Agriculture's Farm Services Agency and the Natural Resources Conservation Service to maintain a proactive approach in developing individual farm plans to address soil erosion, conservation measures, and agricultural practices to preserve and protect tribal and individual trust land resources. Lease Compliance, Air Quality, Pesticide, and Noxious Weed programs, are the enforcement and monitoring portions of the Land Services Program, concerned with monitoring crop rotation and production rates, lease provisions, agricultural practices, agricultural field burning, the use of pesticide and weed control.

As a result of the increased sales of Indian-owned lands in the early 1960s, the Coeur d'Alene Tribal Council initiated the Land Acquisition program, utilizing judgment funds in an attempt to retain as much land in trust for the Tribe as possible. In 1984, the Tribe borrowed funds from US Department of Agriculture's Farmers Home Administration to enhance the continuing efforts of the Tribal Land Acquisition program. Most recently the Tribe has committed revenues from tribal gaming operations for the continued purchase of reservation lands. 
where the seven councilmen sit for their meetings. It's a beautiful room, filled with Indian art and reminders of the life of the Tribe.

His dad has told him that the Tribe runs a Court House here, just like the Benewah County Court House in St. Maries. They have offices for forestry, health, roads, police, real estate, education, lawyers, tribal business, and all kinds of things.

He has gone to the Health Clinic a lot of times with his mother. He knows his dad worked in forestry, before he was elected to the Tribal Council. Reno has a Tribal ID card, making him one of 1,200 enrolled Coeur d'Alene Indians. That gives him certain rights because of the Tribe's treaty agreement with the United States Government.

Many times he's heard his Keena complain that the government hasn't kept the treaty. The government promised it would keep all of the reservation together for the Indians. But over the years, it let two-thirds of the land slip away, piece by piece. The state of Idaho took some. White settlers took a lot.

Still sitting in his dad's big chair, Reno looks around. 'I'm glad my dad's the chairman,' he thinks. 'He says the Tribal Council is trying hard to keep everything the Tribe still has. They're making lots of jobs for people too. He says that the Tribe has 150 people working for them. Maybe someday I'll work here too.'

\section{Coeur D'Alene War Against Steptoe}

As they drive through the rich wheat fields below the Tribal Offices, Reno sees the sun painting the sky red behind Steptoe Butte. The big hill stands like a dark pyramid against the sunset.

"That's where the Coeur d'Alenes beat-up on the Army," says Keena with pride in her voice. "Colonel Steptoe said he was marching his troops to Fort Colville, but he was way off the trail. He circled over here where all our people were out digging roots.
"Steptoe had Nez Perce Indian guides with him. They bragged to the Coeur d'Alenes that the Army would beat us, then the Nez Perce would take our lands. So our people got together with the Spokane and Palouse Indians to drive out the Army.

"Our Chief in those days was Vincent, Hapshineh's dad. He and the missionary, Father Joset, tried to keep our warriors from fighting. But everybody was threatening everyone else.

"Suddenly someone started shooting. Hapshineh's uncle fell off his horse, killed by a soldier. He was a popular man, so everyone got mad and started shooting.

"Our people didn't fight like the Army. Our men rode by at a gallop, one-by-one. They'd hang low behind their horse, to fire a quick shot at a soldier. Then they'd ride away, and got off to reload their old-fashioned rifles. Each man was on his own, riding in and out.

"The Army wanted to fight in formation, as a large group. But they never could get the Indians all in a row so they could charge them. They had 150 soldiers and two big cannons with them, but they couldn't beat us.

"Steptoe turned his men around in defeat. Our warriors kept riding past and shooting at them. Not that many people were killed, like they are in today's wars.

"The old folks said they killed seven soldiers in the battle. We lost three Coeur d'Alenes James Sol-Louis, Zachary and Victor SiJohn.

"Finally Steptoe and his men made it to a little hill at Rosalia, Washington. As the sun went down, the Indians had them surrounded on the hill. The Palouse wanted to kill the soldiers the next day for marching through their land.

"But the Coeur d'Alenes didn't want the soldiers killed. They just wanted them to go away. So Chief Vincent and Father Joset arranged a way to let them off the hill in the darkness of the night. Each Tribe guarded a part of the hill. They had fires built, and they did war dances 
throughout the night. Our old People let the soldiers through the Coeur d'Alene lines, so the soldiers could get away with their lives.

"The Palouse were mad at our people for letting soldiers get away. They were also mad because the Coeur d'Alenes got most of the horses, pack animals, and equipment that Steptoe had to leave behind.

"After beating Steptoe, the Indians were really proud. They thought they could keep the Army away forever. But Father Joset warned them that the Army would come back to take revenge."

\section{Colonel Wright Marches Against THE INDIANS}

“The Coeur d'Alenes were split after that. Some wanted to keep fighting, and some gathered at the Old Mission to try to keep peace. But the Army did come back a couple of months later. Colonel Wright led a huge expedition towards Spokane to punish the Indians.

"He never could get the Indians in an all-out war. Indians kept riding in and out, a few at a time. But this time the soldiers had newer rifles that could shoot farther than our old rifles. $\mathrm{He}$ also shot a cannon at our people.

"The Indian warriors found out they couldn't turn the Army back this time. So they set fire to the grass to try to stampede the Army horses. But the Army was able to get around the smoke and the flames. The Indians backed off then, and just kind of disappeared.

"Then Colonel Wright marched his men west through Spokane and into the valley. There he got even with the Coeur d'Alenes. He burned down a lot of our peoples' barns and log houses along the river and at Liberty Lake. But most of our people drove their herds of cattle and horses safely into the hills.

“Then Colonel Wright did an awful thing. He caught up with a big herd of horses that the Palouse Indians had been driving along with them all summer. Wright had his soldiers shoot all the horses. They say he killed 800 horses. Our people were amazed that Wright could be so mean.

"When Wright couldn't catch up with any more Indians to fight, he just camped at Coeur d'Alene. He was afraid to head up into the mountains. That's when Chief Victor and Father Joset arranged for a peace treaty at the Old Mission.

"All the chiefs and head men signed the treaty at a big meeting below the Old Mission Church. That was 1878. Our people never fought the white people again. The old timers were proud that they always kept the treaty.

"Later on, Wright was really cruel to the Palouse. He caught and hanged about 17 of their warriors. They're war leader, Qualchin, came to Wright's peace conference south of Spokane, under a white flag of truce. But Wright had him hanged as soon as he found out who he was.

"That's when they changed the name of our creek that flows out of the mountains from DeSmet and goes into the Spokane River. Ever Since that day, they started calling it Hangman Creek."

\section{GETTING HOME TO DESMET}

“Well, Reno, I guess that's enough stories for now," says Keena. She's looking at the lights of Tensed and DeSmet nestled against the dark hills at the south end of the reservation.

"Whenever we go by here, I always smile," she says proudly. "That's our Tribal Farm. Those grain elevators and all those combines show everybody that we are still in the farming business.

"After the Government broke up our reservation, the big Indian farms started to dwindle away. Our people began leasing their land to the white farmers. They couldn't afford the expensive machinery.

"But now the Tribal Council is running a big wheat farm of 5,000 acres. That's where your brother, Matt, has been working this summer. 
We're starting to get more of our land back. We're making money for our own people, instead of just for the white farmers. It's really good working for our own people."

"We're home," shouts Reno, as his dad turns off the highway into DeSmet. The big brick building stands high on the hill, where the Sisters used to run a boarding school for girls. Today the Tribe runs all its education and training programs there."

"You kids have a good school there," says Keena. "You get to learn Coeur d'Alene language and Indian dancing and a lot of things the public schools don't teach. That's the only school run by a Tribal School Board. It's good to have Indians running things these days. Times have really changed, Reno. People don't come here to DeSmet for all their activities anymore. Our own kids still go to school with you at the Tribal Grade School, but a lot of the kids go to public schools in Worley and Plummer. People have new homes spread all over the reservation. Everything is different, today. But we still have our memories. And we're still keeping our Tribe and our reservation, so you'll have something special to pass on to your grandchildren."

\section{Coeur d'Alene Basin Restoration and Natural Resource Damage Assessment}

Over 100 years of mining in the upper reaches of the Coeur d'Alene River basin has left vast areas of destroyed habitat and toxic materials. This pollution, over 100 million tones of mine wastes, has affected the 3,900 square mile watershed.

The Coeur d'Alene Tribe is actively pursuing actions necessary to clean up sediment contaminants and restore the natural resources in the Coeur d'Alene basin. Currently this involves an integrated approach, both litigative and cooperative, to restore the basin's natural resources. These efforts include the Tribe's participation in the Bunker Hill Superfund Project, the natural resource damage assessment (NRDA), and the Coeur d'Alene Basin Restoration Project.

The NRDA is one of the first of its type in the nation. The Tribe has joined forces with the US Department of Agriculture and Interior to conduct the damage assessment. This entails conducting over 30 comprehensive studies to understand how the ecosystem has been injured as a result of the release of hazardous substances.

The end result of the NRDA work will be to determine what was lost economically due to the negative impact to the services that were once provided by the healthy ecosystem, and how much it will cost to clean up the system. Once funds are obtained for clean up, it is estimated that restoration will take up to 25 years to complete.

The Coeur d'Alene Basin Restoration Project is designed to address metals source abatement and nutrient management for Lake Coeur d'Alene. 


\section{COLVILLE TRIBAL PROFILE}

\section{LOCATION AND LAND BASE}

Executive Order established reservation in 1872; boundaries were changed by Executive Order the same year (boundaries were Canadian border, Okanogan River and Columbia River). In 1892, the "North Hall" was opened to public domaiun in an agreemnet never ratified by the Senate.

Current land status: total of 1, 414, 133 acres, 935, 440 acres in Tribal Trust, 67, 998 acres in Individual Trust 410,695 acres in Non-Trust

\section{TRIBAL ENROLLMENT}

Tribal memebers primarily include descendants of the Salish and Shahaptian-speaking people: Colvilles, Entiats, Methows, Nespelems, Nes Perce, Southern Okanogans (Sinkaietks), Senijextees, Sinkiuses, Lakes, San Poil, Chelan, Moses and Wenatchees.

Current enrollment: approx. 8,400

\section{Native Language(s)}

dialects of the Salish family (Entiat, Okanogan, Colvile, Lakes, Methow, Wenatchi, San Poil, Nespelem, Chelan, Moses); dialects of Sahaptian family (Palus, Nez Perce)

\section{TRIBAL GOVERNMENT}

Non-IRA Tribe. The Colville Indian Reservation is governed by 14 member Colville Business Council operating at tribal headquarters in Nespelem, Washington.

Economic Base: Major natural resources of the Colville Confederated Tribes are timber, minerals, prime agricultural lands and abundant waters. Colville Tribal Enterprise Corporation (CTEC) consists of a seven member board of directors. With their expertise in business, economic, and industrial operations, they oversee tribal business enterprises, which in turn generates revenues and employment opportunities.

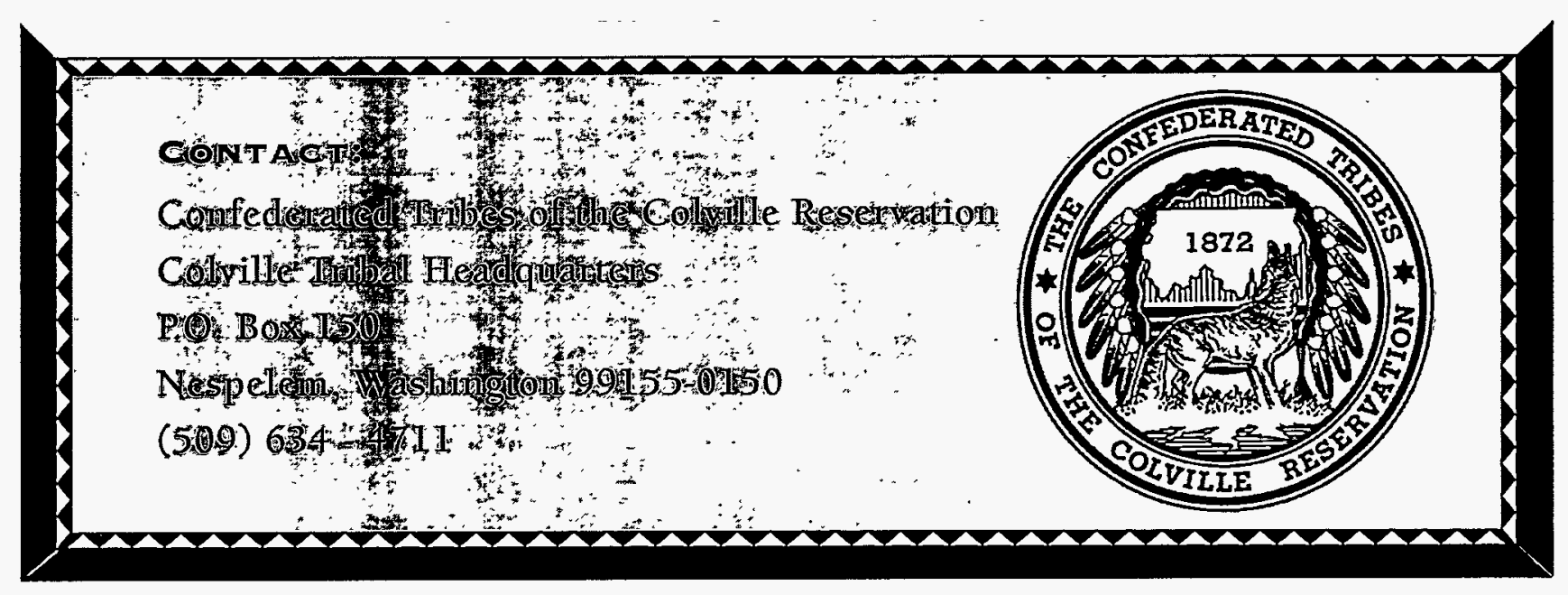




\section{ECONOMIC BASE}

The economy is based on agriculture and natural resources. There are three reservoirs and a fourth currently being constructed, from which the tribes receive fishing and camping revenues. The Tribal Gah Nee Enterprises is a housing project for school employees and the tribes are planning on expanding opportunities for more reservation employment. Tribal government employs approximately 168 people full-time, and another 50 people seasonally, out of a potential workforce of 240 people. 


\section{COLVILLE}

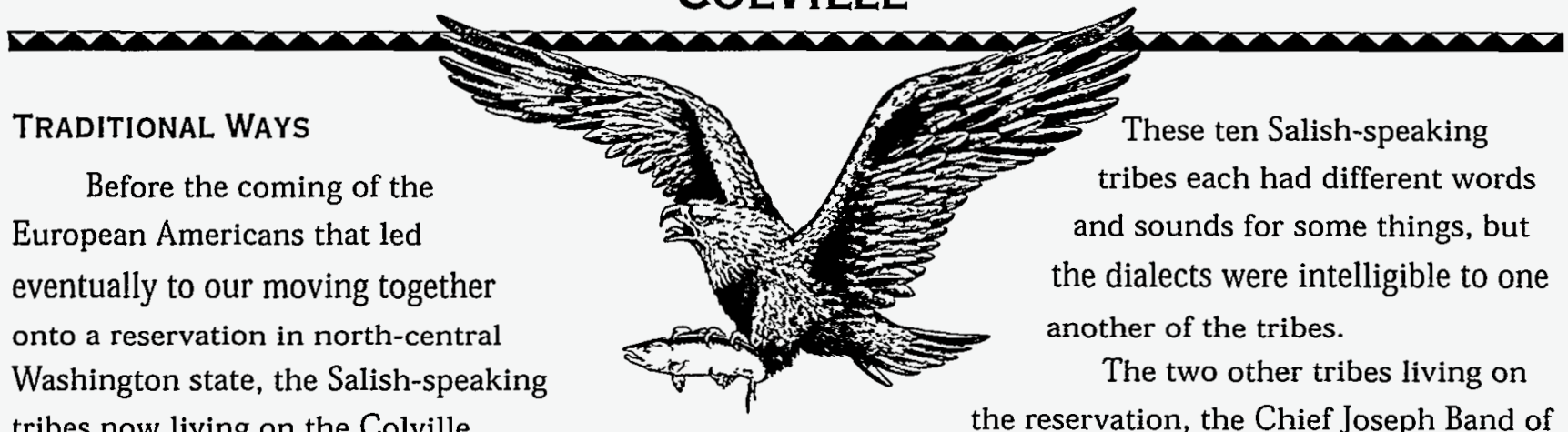
tribes now living on the Colville

Reservation fished, hunted and gathered roots and berries from the eastern foothills of the Cascade Mountains to the western foothills of the Rocky Mountains; and from the Arrow Lakes region in Canada south to prairies and scablands of midWashington state.

Seven of ten Salish-speaking tribes - the Wenatchi, the Chelan, the Entiat, the Methow, the Okanogan, the Nespelem and the San Poil - were named for their winter villages on the terraces at the confluences of the rivers that bear their names, with the Columbia River. The Salish-speaking tribe that had its permanent winter home near the great fishery of Kettle Falls on the Kettle River in north-central Washington was named by the European Americans the Colvile Tribe. Another that lived on the terraces of the Columbia River near the present town of Vantage, they called the Moses-Columbia tribe, after its great chief, Moses. The Salish-speaking tribe now known as the Lakes, the European Americans named for its original home in the Lakes Region of Canada.

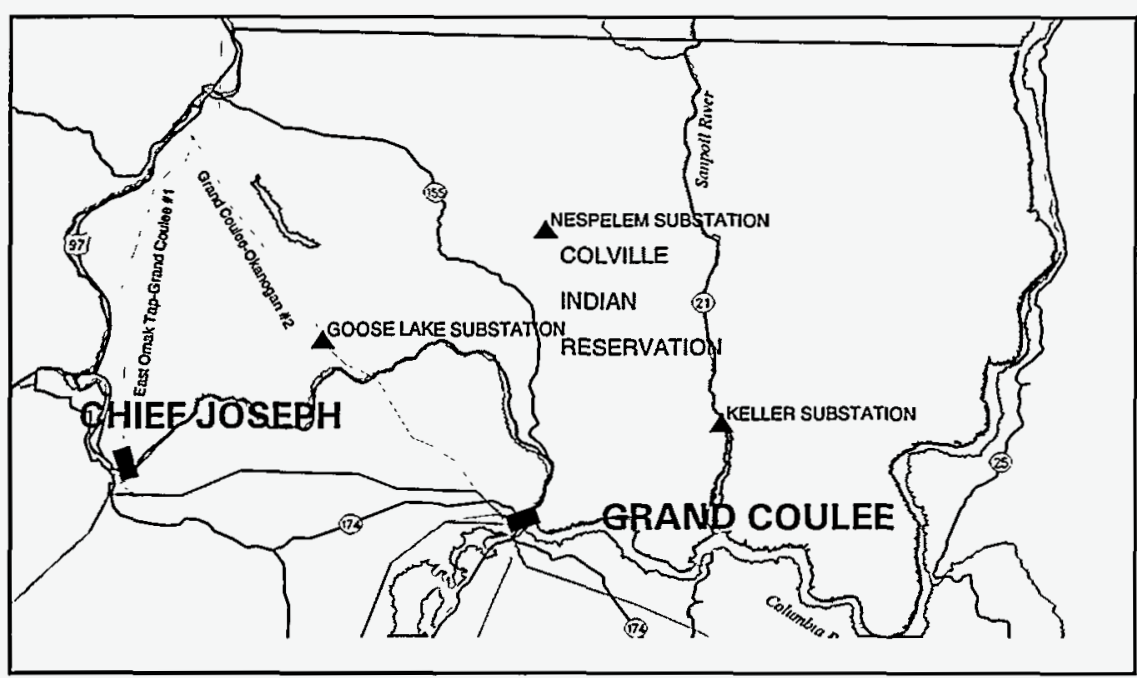

the Nez Perce Tribe and the Palus Tribe, spoke dialects of the Sahaptian language, which are unintelligible to Salish-speaking people. The Chief Joseph people originally ranged throughout northeastern Oregon, southeastern Washington, and central Idaho, while the Palus ranged throughout east central Washington.

In time immemorial, each of the tribes participated in its own seasonal round: gathering roots in its own accustomed places in the early spring; fishing in its own accustomed places for salmon throughout late spring, summer and early autumn; gathering berries and hunting throughout the late autumn; and dancing and celebrating in winter in its own permanent village. Each had its own leaders and its own unique councils as well. However, they shared many ways in common, and intermixed in their seasonal rounds, meeting to trade, game, gather, hunt and fish in the ancient coulees and deep forested river valleys, and the grass-covered gathering grounds.

The Creator gave to us plentifully, and there was no need to war among ourselves and we did not. Instead, we distributed our bounty equally so that no individual wanted for anything. Each man and woman had a soul, and was equal in the eyes of the Creator; and we were equal in one another's eyes.

That way of life is lost to us now. Some of it was lost slowly, when we were removed to the reservation. When the EuroAmericans came, our accustomed gathering and hunting places 
shrank, making it more difficult for us to follow our traditional way of subsistence. When the federal government began building schools and threatening to take away our children if they did not attend and forget Indian ways, we began losing our language and our traditions. With the coming of paper money, we were no longer equals and began measuring each other in terms of EuroAmerican wealth. What the Creator had done for each of us, money - or the lack of it - began to undo.

Other ways of life were lost quickly and decisively. When the waters of the Columbia River were trapped behind Grand Coulee Dam in 1934 , the salmon that had been at the center or our way of life ceased to come up-river. The completion of Chief Joseph Dam a few years later blocked them even further downstream. By that time, the willingness of the United States government to deal with our chiefs had declined; with the passage of the Indian Reorganization Act in 1934, which mandated that tribes wishing federal recognition accept only the forms of selfgovernment offered in the bill, cooperation with the traditional chiefs ended altogether. The period of the great chiefs of the Colville Tribes ended during the first half of the twentieth century with Chief Moses, Chief Joseph, Chief Jim James, Chief Sarsopkin, Chief James Bernard and a few others. Once the chiefs lost much of their authority, our

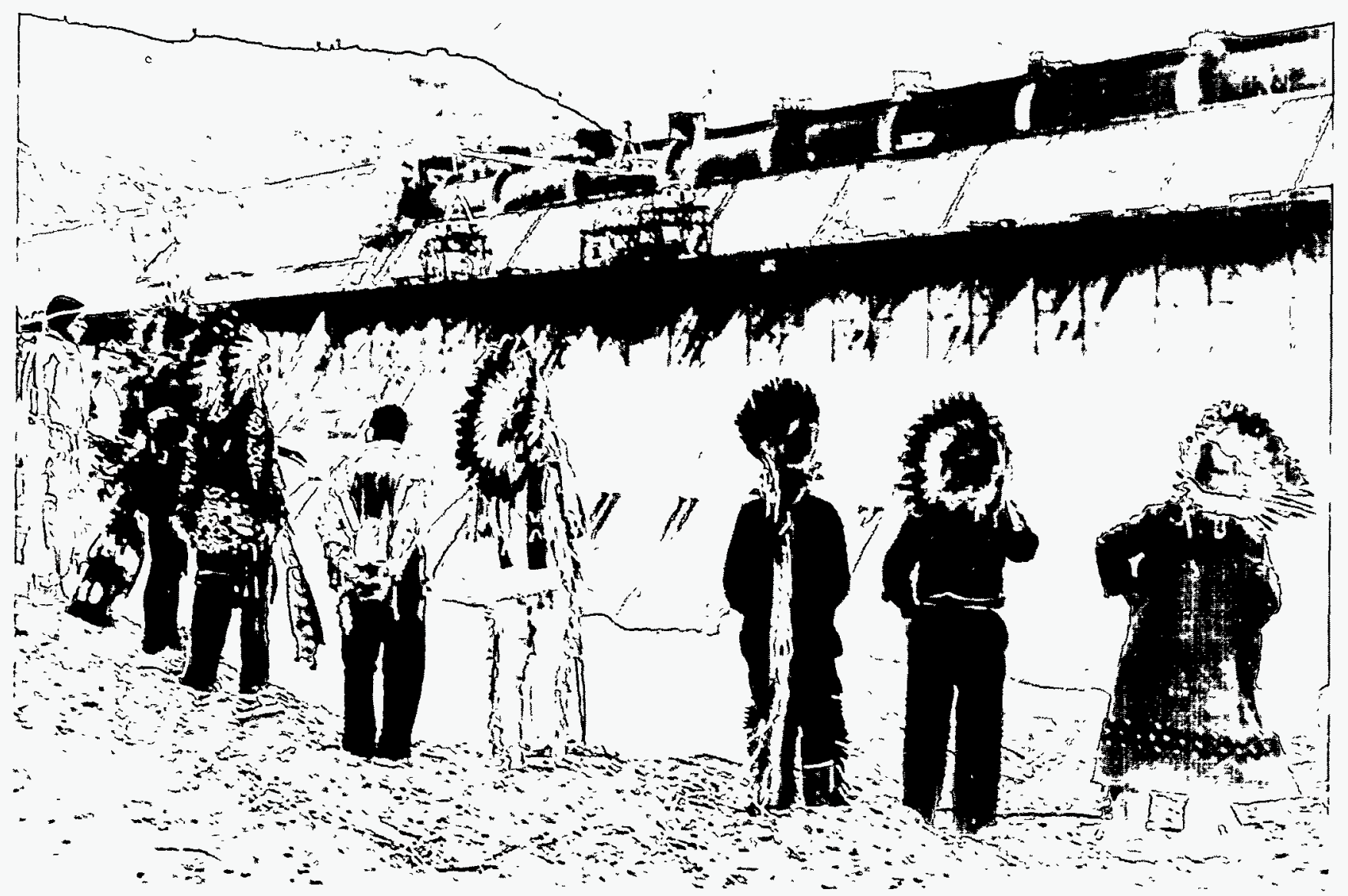


councils ceased to operate as they once had. Rather than the men gathering together and hashing out issues until they agreed on a fair course of action, our people began forming into factions and casting paper votes. The individuality and power of each soul to speak for itself was buried in new political realities. The harmony that had been established by the Creator and our chiefs among us was lost.

With the waters rising behind the great dams, our winter villages on the low terraces and our fordings where we had crossed to the root grounds were drowned. Within a few years of the building of the dams, what had been slowly seeping away was inundated forever. We, who had revered the wild, rushing, talking waters of Kettle Falls, where each year salmon came back to feed us if only we prepared ourselves and acted correctly, watched the falls go silent behind the new dam. Salmon did not come again. We were ashamed because we felt that we had not prepared ourselves and acted correctly.

This is only an incomplete description of the process, however, because it sees our old ways as the Euro-Americans see them, as a list of things that we did to get along on the land. The list segregated our ways into politics, or subsistence, or religion.

That is not how our life was. Our way of life was one, beginning with Sweat Lodge, the Creator. The Creator created the land and us, and he created helpers, and guides and guardians to teach us and to give us power. He created the land so that it would talk to us through its plants and animals and rocks and tells us how to treat it. When we were forced by Indian agents to live in houses, the old people complained that they could no longer hear the earth talking. One woman left her house each night to sleep in her tipi until the Indian agents, tiring of taking the tipi down, burned it.

Each thread that was pulled away from the whole - whether the thread of how to treat our children, or how to treat our elders, or how to revere our ancestors, or how to gain power from our spirit guides, or how to live on the earth, or how to live with one another - was another thread unraveling the whole cloth that was our way of life. When we forgot our language, we could not hear the land and water talking to us anymore.

\section{HERE IS THE WAY IT WAS, BEGINNING WITH SWEAT} LODGE:

Sweat Lodge was a chief long, long ago; but he wasn't called Sweat Lodge then. He was just called Chief. He decided to create all the animals and all the birds. So he created them all. He named each animal and each bird. Then he told each one of them: "In times to come, when the people have been created, they will send their children out, during the day or during the night, and you will talk to them and tell them what they will be able to do when they grow up. You will tell the boys that they are to get things easily, are to be good hunters, good fishermen, good gamblers and so on. You will tell the girls that they will be able to get things that they want easily. At that time I will be Sweat Lodge myself.

Then he spoke to them again: "I'll have no body, no head, nor will I be able to see. Whoever desires to construct me will have the right to do so. The one that builds me may pray to me for good looks, or whatever he may wish - the one that made me. I'll take pity on him, and I'll give him what he requests - the one that made me. People may approach me thus: If anyone is injured, or is he is sick, or if he is poisoned, he may come to me for help and I'll give it to him. Also, when anyone is dying he may come to me and I'll help him then also. I'll help him to see the next world. So in this world I am Sweat Lodge, for the help of human beings."

San Poil origin myth, as told by Jim James, interpreted by William Burke. [Ray 1932]

Before Sun and Moon were created, there were two brothers that enjoyed each other's company, and spent all their time together; but one brother had an 
accident and was burned terribly. The brother was so badly disfigured that none of the Creator's other creatures could look at him. The Creator took pity on the brother, and made him the sun, so that no one could see his disfigurement. The other brother he made the moon. Even now, Sun and Moon miss each other's company so much that on their journey through they sky they still meet in passing.

We knew from our stories that our own families were ordained with grandmother, grandfather, mother, father, brothers, sisters, aunts and uncles because Earth is Mother, Water is Father, Sun and Moon are Brothers and the four winds are Sisters. Our language had no words for us that separated us from the rest of creation, such as "people" or "humans." Our words for children meant "sacred beings." The children were our future and they were raised by grandparents, aunts and uncles, and parents, and the entire village because the Creator did not separate out his creation but left all of it to tend after itself as one. Our old people we called "spiritual beings of the earth," and we revered them and kept them close.

Because Sweat Lodge is also Chief, each village had its own chief. The chief had the responsibility for maintaining harmony in the village, just as Sweat Lodge established harmony in creation. If there were a dispute within a village, or a decision had to be made, a council was called in the tipi of the leader. Each person spoke before the leader made a decision. Often, as they spoke, the men began to come together on an opinion, so that by the time the leader voiced his decision, the group would be unanimous. If the group was not unanimous, the dissenters could move to another village, where they would be accepted without question. No one person demanded his "rights," and no person took up arms to defend his position. Harmony in the village mirrored harmony in nature.

We are the Creator's children, and we gained the power and wisdom to live correctly with his creation through the spirit guides he created to help us. We gained these spirit guides as adolescents on our individual spirit quests. The great winter celebrations were devoted to bringing out spirit guides.

Before going out on a spirit quest as a teenager, we would spend many days in the sweat lodge, praying to Sweat Lodge to purify us. Then we would travel alone to a sacred site in the mountains to wait the approach of the spirit guide. We built a fire and fasted and prayed for up to ten days. If a spirit came, it would usually come in a vision in the form of a bird, fish or animal. The spirit guide taught us its song. The particular powers of that guide would be a part of our makeup for the rest of our lives, be it the cunning of Coyote, the bravery of Bear, the wisdom of Owl, the strength of Salmon or something else. After we had learned the song, we would rise and go home, never mentioning what had happened and never being asked. Depending on the type of spirit and its power, it might set us on the path to becoming a great healer, or a Salmon Chief, or a political leader, or an Indian doctor.

Sometimes, however, the spirit did not come. If the spirit did not come, so be it. A spirit guide did not give status, it gave the power to follow a path successfully, if the path was accepted.

When a spirit reached out to a boy or a girl, its power could not be used until the youth reached adulthood, after the spirit was "brought out" during the winter dances with the help of a shaman who himself had powerful spirit guides:

To be successful, a person had to have power from a spirit. This spirit came close to its human partner every winter, and their bond had to be expressed at a public gathering where individuals sang the songs that had been given to them at the first contact with the spirit. Although the song was given when a person was young, it was not "brought out" in public until he or she was old and respected....

People gathered in a large home with a sacred pole set up in the middle. An old man or woman 


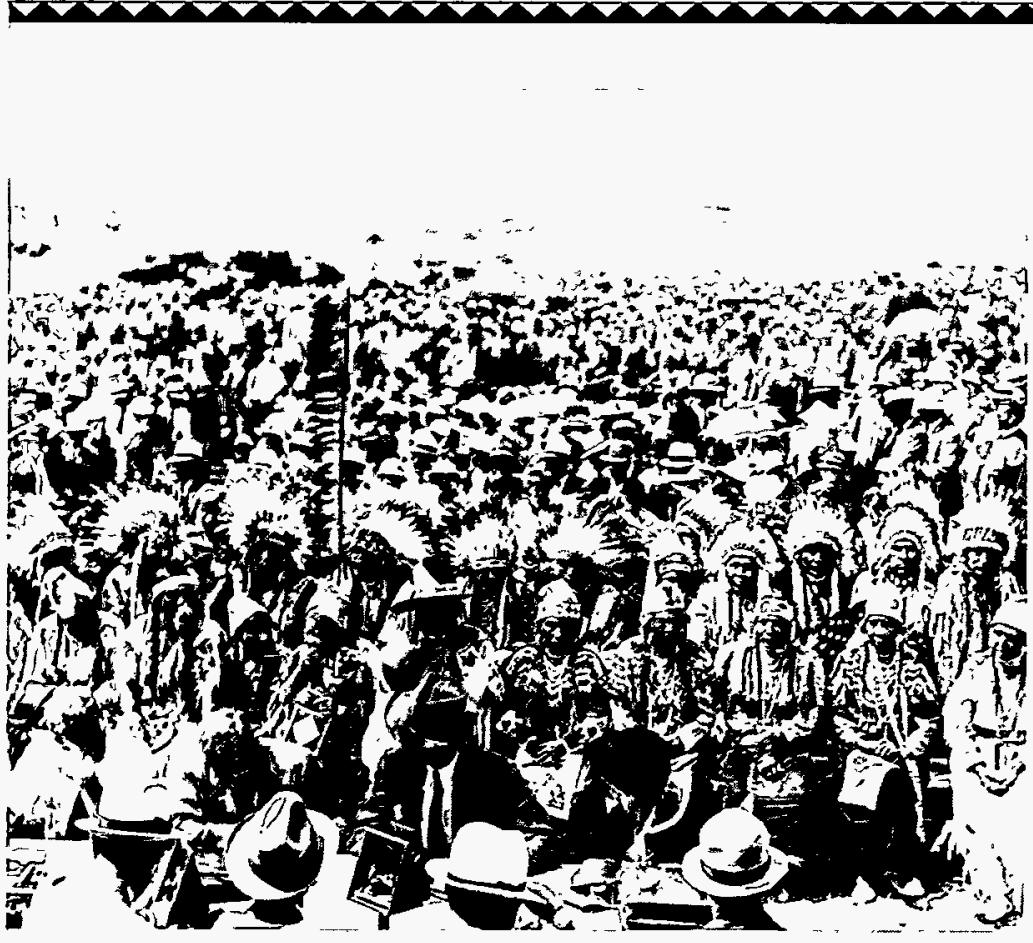

\section{Historical Dateline for Colville Indian Reservation}

The original Colville Indian Reservation was established by Executive Order of April 9 1872, for the use and occupancy of the Methow, Okanogan, San Poil, Lakes, Colville, Calispel, Spokane, Coeur d'Alene and such other Indians as the Department saw fit to locate thereon.

Under Executive Order of July 2,1872 , the original reservation in existence for less than three months - was divided into the North and South halves and the North Half, consisting of more than half of the original 2,900,000 acres, was restored to the public domain.

In 1886, members of the Chief Moses tribal groups were moved to the Colville Reservation pursuant to an agreement with Chief Moses ratified by an Act of Congress on July 4, 1884. The Columbia Reservation had been established by Executive Order of April 19, 1879, "for permanent use and occupancy of Chief Moses and his people, and such other friendly Indians as may elect to settle thereon with his consent and that of the Secretary of the Interior." This group of tribes included the Columbia, the Chelan, the Entiat, and the Wenatchee. Also, during the year 1885 and later years, the Government moved to the Colville Reservation, members of the Joseph Band of Nez Perce Indians and members of the Palus Tribe. Except for certain tracts allotted to tribal members, the Columbia Reservation was restored to the public domain by the Executive Order of May 1, 1886.

The South Half of the Colville Reservation consisted of approximately 1,400,000 acres when Congress passed the Act of March 22, 1906, authorizing the classification, appraisal and sale of the lands to the public, following the distribution of 80 -acre allotments to tribal members. Net proceeds of the sales were to be deposited in the treasury for the benefit of the Indians. The Presidential Proclamation of May 3, 1916 opened to entry all the lands of the South Half with the exception of allotted tracts and classified timberlands.

By Departmental Orders of September 19, 1934, and November 19,1939, undisposed lands (including the timberlands which had not been open to entry) were withdrawn from any further disposition until the matter of their return to tribal ownership was settled. Then, by the Act of July 24,1956 , the remaining undisposed lands in the South Half, comprising approximately 818,000 acres, were restored to tribal ownership.

The land status of the Colville Reservation is as follows:

$\begin{array}{lr}\text { Tribal Trust } & 935,440 \\ \text { Individual Trust } & 67,998 \\ \text { Non Trust } & 410,695 \\ \text { Total } & 1,414,133\end{array}$


would go up to it and start singing while others sang and drummed along. A man might go up and sing softly and then pause to pray.

Sometimes he would begin again, telling everyone, "My children, follow my song," and everyone joined in with the old singer but using a lower tone so his voice could always be heard.... [T] his symbolized the whole tribe following a wise chief, shaman or leader for the benefit of all.

A visionary might sing for an hour or less before abruptly changing to another song, slowly getting up while shaking the pole and engaging in a few quick steps around the middle area. This was a sign that others could get up and dance in the same way, moving in place before resuming their seats. The shaman sometimes motioned with a wave of his hand, saying, "Come, follow my dance so your life may be spared long enough to see the sunshine of summer and the green grass under your feet again." The audience then came forward and closed in gradually around the singer, first dancing slowly with his voice easily heard, then growing more intense as they got the vibrating power of the spirit and the song as their bodies moved faster until they lost control in the joy of dancing....

....Men largely imitated animals or prey important to successful hunters for help in the future. Women usually represented power important for their own tasks as berry pickers, basket makers, or baby doctors....

....The dancing continued for two or three nights before the shamans were ready to initiate a budding medicine man or woman.... When a man or woman had previously experienced the finding of supernatural power to guide them, it usually left them alone in childhood. It came back when they were adults, appearing as a dream or vision to remind them of the contract, saying, "Sing my song and the world will shine for you.".... from Mourning Dove, a Salishan Autobiography, 1939

One of the things we were forced to do when the Euro-American political and religious managers began exerting authority over us on the reservations was to rid ourselves of the clothing and symbols of our winter dances. Old people still remember being ordered to bring these things to the mission, where they were buried in the ground. They were ashamed because they could not protect these symbols of the Creator's creation and their harmony with it, and many of the old people grew sick the following winter when the dances could not be held.

The Creator provided for us by sending us Coyote to instruct us and to help us.

In the beginning, a long time ago, Coyote was a man. He went about helping the people. He was interested in their fortunes, and did a great deal to make life better on earth. It is hard to tell what a miserable place the world would be now if Coyote hadn't changed things as he did.

Fox was Coyote's friend and advisor. Whenever Coyote was in trouble, he called on Fox to help him, and usually he did. Coyote nearly always took credit though. He would say, "Oh yes, I knew that all the time."

Coyote was sometimes tricky, and sometimes foolish. Most of what he did was for the best though.

Bob Covington [Ray 1932]

Of the many things Coyote did to help us, the most important was to bring the salmon upstream.

Coyote heard that there were five sisters living near the mouth of the Columbia River and keeping wonderful fish in a trap. Coyote wanted to eat these fish, so he went there. Just above the trap, he turned himself into a baby fastened into a cradleboard, and floated down the river. The sisters saw him and having no children of their own, rescued him, although the youngest girl was vocal about her suspicion that the baby was really Coyote. Infused with maternal sentiments, the older sisters paid no attention...

Every day the women went out to gather food to eat with their fish, and while they were away, Coyote assumed his usual form and worked on releasing the salmon. He made five stone bowls and five picks, 
went down to the trap, and began to dislodge its supports. This went on for some time, with Coyote turning himself back into a baby before the sisters came home each night.

One day, however, the youngest sister could stand it no longer and went back home to test her suspicions. Sure enough, the baby was not there, and looking further, she discovered Coyote dismantling the salmon trap. Yelling to her sisters that Coyote was stealing their salmon, she mobilized an attack. Coyote wore a stone bowl like a helmet until it broke under the blows of the sisters; then he put on another. As the last bowl and the last pick broke, the salmon were released and Coyote led them upriver. Whenever he was hungry, he called a salmon onto a beach, clubbed it, cooked it and ate it. By returning the bones to the river, however, the salmon came back to life and continued upstream.

Coyote...soon tired of this easy life and decided to visit the people living in villages at the confluences of the tributaries of the Columbia River. He entered each village and offered the gift of salmon in return for a wife while he stayed in the community. The size and number of salmon sent into local streams were consistent with the beauty of the wife.

Thus, the Colviles at Kettle Falls were most hospitable and received plentiful runs of huge salmon. The Entiats were less generous, so their river had a brief run of small fish. The Methows were mildly accommodating and gained moderatelysized salmon. Because the Chelans and Nespelems refused him, their rivers now have waterfalls blocking passage upriver.

Nothing better shows the oneness of our old ways than our relationship with Salmon. We caught the salmon and subsisted through it, but Salmon would not let us catch it if we did not prepare properly and pursue him correctly. For every type of fishing, Coyote set the techniques and fishing gear to be used. He left his instructions on rock faces, where, at each locale, he drew spears, traps, nets or weirs. These rock drawings can still be seen.

\section{Months and Seasons}

Each month name indicates the appropriate activity for that season. The names are listed below with their equivalents in the Julian calendar along with timely activities.

January - sk'wsus - "Taken or burned fast" (food and wood were used up quickly at this time, and eyes were blackened with red cedar soot when hunting)

February - spaqt - "Pinch" (hands stick to frozen surfaces)

March - s-kn'ir-mn' - Buttercups (Buttercup Moon)

April — skpIIckltn — Budding out May - s-kw IIn'-kw'n'Im - Roots: wild potatoes, balsamroot, camas, bitterroot

June - k-m flktoetn - Wild carrots, balsam seeds (also called xwmina, "steelhead")

July — k-s'ya?-tn - Serviceberries, up to eight varieties

August - lexw-lexwt和 - "Holes, holes": chokecherries, huckleberries (some root digging)

September - snk'ףllkwis - "salmon spawn": cedar bark roots for basketry, salmon run in Okanogan River

October - slqmis - Salmon run in Columbia, traps set up at Brewster

November - sqwl'it - "Gather tree moss": fall hunting (sKaym)

December - sk $\$$ ?ay - Winter 
As long as the people revered the creation and remained a harmonious part of it, things went well. When somebody offended the harmony, the people suffered. The places of great plenty and celebration, such as the salmon fishing at Kettle Falls, could be plunged into misery.

Before fishing could begin, there had to be a salmon feast conducted by the Salmon Chief. The protocol of the ceremony is still conducted very much according to the instructions laid down by Coyote in the following legend:

After assisting an old man to catch fish, Coyote showed him how to prepare them. First he showed him to put a stick in the mouth and then bend it back and break off the head. Next he showed him how to make a long sharp pole to stick in the salmon for holding it over the fire and roasting it. Then: Coyote said, "Now remember this: For the first week go down to the trap and take out the salmon, but when you are fixing one to cook, never use a knife to cut it in any way. Always cook the fish over the fire on sticks, the way I have showed you; never boil it. Then, after it is roasted, open it carefully and take out the backbone without breaking it. Also, save the back part of the head; never eat that. If you do not do these things as I have said, either a big storm will come up and it will rain until you are drowned, or you will be bitten by a rattlesnake; one of these things will be sure to happen to you. After you have taken the backbone and the back of the head, wrap them carefully in tules and put them somewhere in a tree or someplace where they can't be bothered.

"If you do as I say you will always have salmon in your trap. I'm telling you these things because I am going to die sometime and I want you to know what to do. After this, men will always place traps up and down the river to catch salmon; the man who has the first trap in the river will be chief and you should always do anything he tells you.

"After the first week, you can boil your salmon or cook it anyway you wish, but always take care of the bones; never leave them where they can be stepped on, or stepped over..."

Bob Covington [Ray 1932]

Coyote decreed that there should be Salmon Chiefs, and so there were Salmon Chiefs. His salmon power gave him authority over all the activities surrounding communal traps, such as the materials to be used in constructing it, the site for its construction, and supervision of the daily distribution of the salmon to the families. If the catch on a day was small, the Salmon Chief stayed up all night praying. Sometimes another shaman might test the power of the Salmon Chief by stopping the salmon run. In this case, the Salmon Chief had to call on his guardian spirit to overcome the shaman and inflict punishment. If this did not work, the Salmon Chief would step down in favor of a stronger shaman whom could bring back the salmon run.

While each of the bands that now live on the Colville Reservation once had preferred fishing sites, families moved among the sites at will. Below, Mourning Dove describes the scene at Kettle Falls, before it was drowned by the waters of the dam.

In Chokecherry Moon (August), my parents moved their tipi to our prime fish location at Kettle Falls on the upper Columbia River. When we arrived, natives were already in the process of spearing king salmon....

The Indians gathered at the falls every year to spear salmon and dry it for the winter. All the surrounding tribes were welcome at this summer resort in the homeland of my Colvile people. It was a beautiful place to camp, with cliffs overhanging the falls on the west side and trails leading to the water between the high grayish-white rock formations that so often glistened in the sunlight. On the east side were flat rock slabs much closer to the whirling pools, where campers could most easily get water. The falls passed on either side of a large central rock that created a smooth backwater behind it. The area near the falls was filled with mist, ribboned with 
colors creating a faint rainbow on a summer evening....

Our camp was close to the Colvile on the west, beside our Okanogan distant relatives from Osoyoos. The west side was called Lachin (Woven Kettle or Bucket) because of the many depressions made by whirlpools there. The east side was generally known as S-calmachin (Dug Ground) because the ground was rough with boulders...Tribes generally camped in specific areas and Colvile hospitality saw to it that no visitor ever left without a full load of dried salmon....

Mourning Dove 1939

This is an example of how our world was one for us. The great fishery at Kettle Falls was a place of friendliness and socializing. It was also a place where each family could gain nearly enough fish to last through the winter. But the fish would not come if ceremonies and rituals were not performed correctly. If the ceremonies and rituals were not performed properly, the salmon did not come, we were plunged into starvation and despair.

Thus, the Euro-Americans could not ravel the ceremonial thread, without raveling the social thread and the subsistence thread. Nor could they ravel the subsistence thread without raveling the social and ceremonial thread. It was all one. When the salmon stopped coming after the building of the dams, we blamed ourselves.

Perhaps there was something we did, or did not do. it is a pain and shame that still lives in the old people.

\section{BRINGING TRADITION FORWARD}

I was brought up traditionally. I didn't know at the time that it was traditional, but I didn't know anything else. Along the way, we've lost contact with our culture for some reason. Our people began drifting away from it. Part of it was when they wouldn't let our people speak Indian anymore. A big part of it happened when they started allowing Indians to go into taverns and buy liquor. That was the biggest downfall for our people, because alcohol developed a new addition to our culture. Pretty soon, for a lot of our people, alcohol became a way of life. It still prevails today. Because we as children grew up with that, we thought it was a normal way of life. We didn't know anything else, and that became our culture, and we forgot who we were.

My family was hit by that badly. We have a large family. I have three brothers who are still living, and two brothers who died before I was even born. I had six sisters, and three of them are gone now, two of them alcohol-related. Our family was so devastated by it, that everyone of us was lost for a long time. Some of us quit drinking about ten years ago and then, about two years ago we began taking a look at ourselves. We didn't talk to each other, we didn't visit each other, we never went to each other's house. It was the booze that had caused that separation, and even though we didn't drink anymore, we didn't know that we were not a family. Finally we got together and had a meeting and talked about it. The first meeting, we had a few people; the next meeting we had thirty people; the next meeting we had about sixty people... family members from five years-olds all the way up to my mother, who's about 90 now. We talked about things. We talked about problems in our lives, and what 
happened when were young. We talked about some of the things that made us live our lives the way we had. By doing that we began letting these little kids know - these five and six years old - that some of the things happening weren't right. We weren't a strong family because we quit taking care of each other. We were put on this earth to take care of each other. We were put on this earth to take care of Mother Earth and everything that's on it.

When we were growing up - anyone my age or the generations before us - we were always told that before the non-Indians came, the only way the important things were handed down was orally. It was done by having feasts, by having giveaways. It was done by having winter dances, by celebrations. Our people liked to do that, because it was the way of communicating the wisdom that had been handed down to them. They conveyed the wisdom down to us that could allow us to continue to be a surviving people. As I was growing up, my mother did that. We went digging for camas and bitterroot. We went huckleberry picking. We had dances, and giveaways and name-givings, and went to powwows where we could observe other people doing the things we were doing. These were all the things that were given to me as I was growing up, but I never did realize it. I didn't pay attention when they told me about the sweatlodge, and when they told me it was important to go to winter dances. I didn't pay attention when they told me it was important to continue digging roots or picking huckleberries, or even hunting and fishing. I didn't make the connection about how important it should be until later in life when we had the family meetings, and we began talking about why we weren't together anymore. We weren't together because we had forgotten who we were. The only way to get back in contact with that is to go back and do what our people did a long time ago, to begin relearning.

I don't know if we will get all of it back, but we will get enough of it back so that our people will be a strong, caring people again. I think the new hierarchical form of government has led to factionalism until recently. Our tribe was governed by people that figured that because they had a modern education, they had the wherewithal to compete and function in today's society. Granted, they had the tools. But they couldn't make the connection between the people they were governing, and the modern-day economic things that were driving our society. That was the situation; but today, because of the people elected recently, we are more traditional. We begin meetings with a thanksgiving, and a prayer that our Creator will be with us at the meeting. It sets a tone, so that people are more trusting, and that's important. We encourage people to go out and get an education, but to come back and bring their education to Indian ways. To come back and be a member of this cultural group.

In the past, tribal resource managers have wanted to get the most economic gain from the resource base, while the traditionals wanted to see resources preserved for future generations. We have been told we were put on this earth to take care of Mother Nature. Just how we do that is the issue with the resource management people. This is what I was talking about, when I talked about people going out and getting their education. Some tribal resource managers went out and came back and told us, "This is called a silvacultural way of doing things, and we need to do things this way because it was how we were taught in school. You cut ten trees, plant three, and pretty soon you have a forest again." That's what we were told. I don't think our people did it that way a long time ago. They pretty much let Mother Nature do it her way, and she did a pretty good job. And because she did a good job, our people watched her. A long time ago, our people burned every five years, and it helped the forest and the huckleberries grow. So we wanted to bring the two cultures together. We didn't feel that clear-cutting was the way to manage the forest. When our people burned every five years, the underbrush never grew that much, and so the fires didn't get that hot or burn that fast. Now, with all the fire suppression over the 
years, there's a lot of underbrush and the fires burn so hot, they burn all the trees. The resource

managers are beginning to see that, at least with fire suppression, they were wrong. Now they go out and cut. The resource managers call them clear-cuts because it helps their peace of mind; but they leave some of the trees.

I think the council would like to see the people are drug- and alcohol-free for the future. Everyone would have a home of their own on land of their own. Our enterprises would be flourishing. The people who wanted to work would be working, but the people who did not want to work would be taken care of, because we should not be forgetting anybody. We need to help people. It's in the nature of Indian people. The Indian people want to be primarily left alone to govern themselves, but they would like to have interaction with county, state and federal governments. We would like to be an economic force in the northeastern part of the state, which would reconcile things with the state, since we would provide jobs not just for Indians, but for non-Indians as well.

Colville Business Council member 


\section{KAlispel Tribal PROFile}

\section{LOCATION AND LAND BASE}

The members of the Kalispel Indian Community live on or near their reservation, which contained 4,620 acres when it was established by executive order on March 23, 1914, on the eastern shores of the Pend Oreille River, about fifty miles north of Spokane.

\section{TRIBAL ENROLLMENT}

In 1985, membership stood at 259.

\section{Native Language}

Dialect of the Salish Family

\section{TRIBAL GOVERNMENT}

Kalispel Indian Council

IRA Tribe

ECONOMIC BASE

Tribal Casino

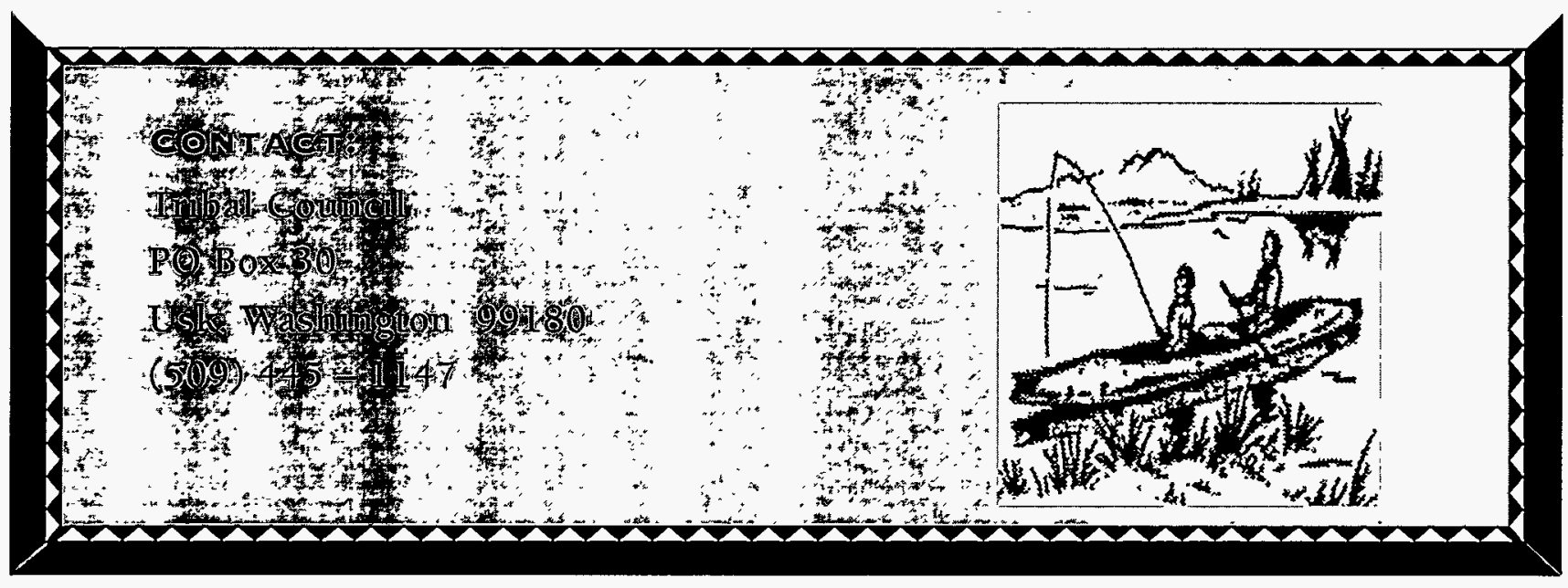




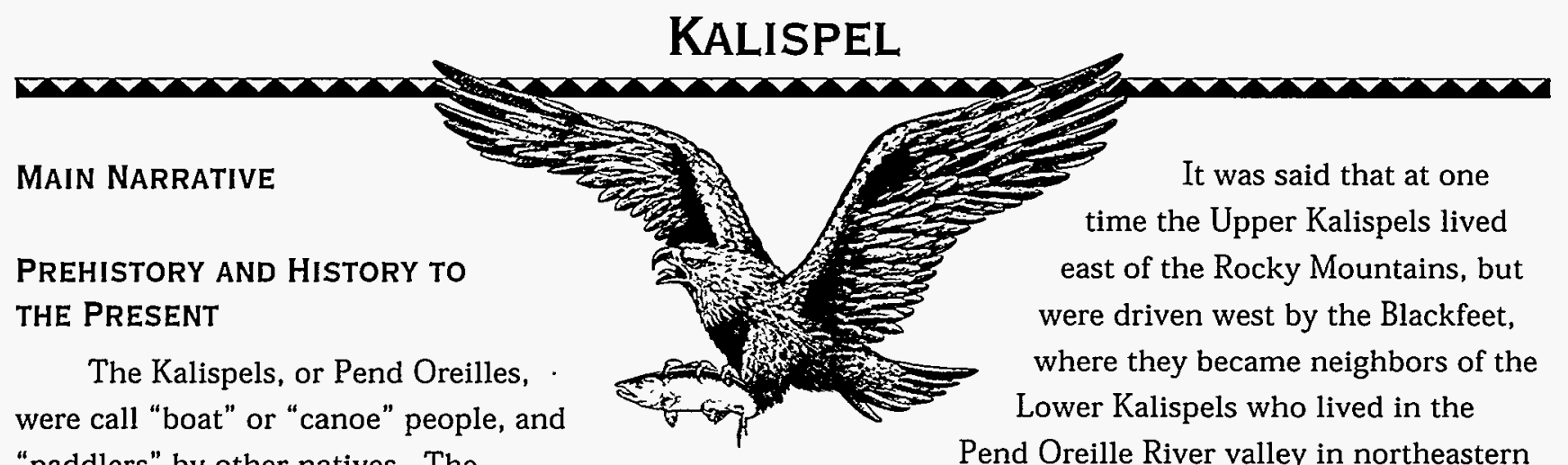
"paddlers" by other natives. The

Pend Oreille River valley in northeastern designation Pend d'Oreille was given them by French-Canadian fur men. It means literally either "to hang from, at, or around the ear," or "ear pendants."

The Kalispel were divided into upper and lower groups with little dialectic variation in their common Salish language. The Lower Kalispels were known for their low-riding canoes, which had distinctive snubbed prows to meet the buffets of gusty winds on Lake Pend Oreille in northern Idaho. They were also noted for their horsemanship, and for their proficiency in making bread out of camas root, which caused them also to be called "camas people." The Upper Kalispels were sometimes called by a name meaning "people of the confluence," from a place at the outlet of Lake Pend Oreille where a considerable band formerly wintered.

Washington state and northern Idaho. The Lower Kalispels also lived in northern Idaho on Lake Pend Oreille, from which flows the Pend Oreille River, and on Priest Lake; and in Montana and Idaho along the lower Clark Fork River, which flows into Lake Pend Oreille. The Upper Kalispels lived east of the Lower Kalispels in Montana; on Thompson Lake and on the Flathead Lakes; on the Flathead River, west past Thompson Falls to Lake Pend Oreille; on Horse Plains; and around present-day Missoula.

Some have considered the Chewelahs of northeastern Washington a Kalispel group. They were culturally related to the Kalispels, but spoke a slightly different dialect and remained aloof. The Chewelah Mountains have also been called the Calispell Mountains. A city in Western Montana also bears the name Kalispell. There is a Calispel Lake in Washington state.

The Kalispel numbers (both

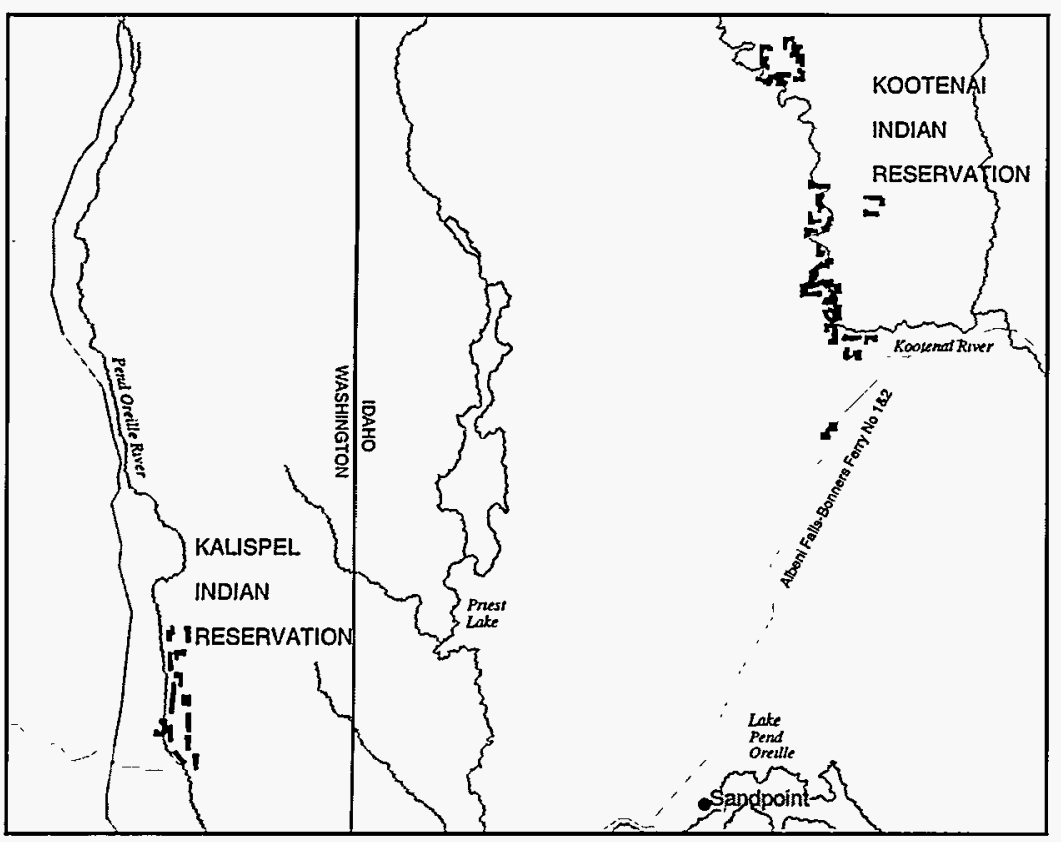
Upper and Lower) in 1780 have been estimated to have been 1,600. In 1805 to 1806 they were estimated at 853 , and in 1850 at 1,000 . In recorded times, the Kalispels hunted as far east as the Great Plains, as far north as Canada, and as far south as the Salmon River country in Idaho. The Kalispels development resembled that of the Kutenai neighbors. Both tribes were divided into upper and lower branches, and both came under the influence of white fur traders after David Thompson of the North West Company selected the site of his Kullyspell House on the eastern shores of Lake 
Pend Oreille in September 1809. Like the Kutenais, the Kalispels were visited by the Roman Catholic missionary Reverend Pierre DeSmet, S.J. who, in 1846, established the Saint Ignatius Mission near what is now Cusick, Washington. In the spring of 1845 , the Reverend Adrian Hoecken, S.J. had begun the Saint Michael's Mission on the Pend Oreille River at Albeni Falls. Later, it was removed downstream and renamed Saint Ignatius. The mission was moved to the Flathead, or Jocko, Reservation in Montana in 1854.

The upper Kalispels followed the mission, unlike the Lower Kalispels, who refused to move from their homeland. Also, unlike the Lower Kalispels, the Upper Kalispels under the Chief, Alexander, were among those who met Washington Territorial Governor and Superintendent of Indian Affairs, Isaac Stevens in council at Hell Gate, Montana, in July 1855, after which they were assigned with the Kutenais and the Flatheads to the Flathead Reservation. From then on developments among the Upper Kalispels followed closely those of the other peoples on that reservation.

The Kalispel Reservation is descended from the Lower Kalispels, or Lower Pend d'Oreilles, who lived in what is now northeastern Washington state and northern Idaho.

The members of the Kalispel Indian Community live on or near their reservation, which contained 4,620 acres when it was established by executive order on March 23, 1914, on the eastern shores of the Pend Oreille River, about fifty miles north of Spokane. In 1985, membership stood at 259 .

The Yakima Indian War, which broke out in 1855, prevented Lower Kalispels, Spokanes, Coeur d'Alenes and Colvilles from meeting with Dr. R.H. Lansdale, with whom they expected to make a treaty. Advised that the Saint Ignatius Mission had been moved to the Flathead, Stevens assumed that the Lower Kalispels would also sign a treaty to remove there. In August and September 1855, some of both Kalispel branches removed to the area around the transplanted mission. Victor, or Happy Man, was the successor of the Roman Catholic chief, Loyola, of the Lower Kalispels. Both Victor and his son, Marcella (Masselow) disdained to live on the Flathead Reservation with Indians of other tribes, and for the most part, the Lower Kalispels remained in their homeland. Ironically, at the time, the Lower Kalispels were an amalgam of Kalispel, Spokane and Flathead peoples.

During the Spokane-Coeur d'Alene phase of the Indian War of 1858, most Kalispels refrained from hostilities. In the 1880 s, despite the pressure of railroad surveyors and white settlers in the Pend Oreille River valley, about 400 Kalispels remained in that country. Their days of freedom were numbered, however, because of such developments as the Northern Pacific Railroad's acquisition of their lands under the railroad's 1864 congressional charter. By 1881 , about seventy-five miles of track had been laid around Lake Pend Oreille, and the railroad was selling its government-granted lands to white settlers.

Under such pressures Victor in 1884 requested compensation for the lands lost. $\mathrm{He}$ also requested a reservation in his people's homelands. Public land surveys followed in 1886 , and in that same year cavalry troops arrived to control Indian-white conflicts over lands. Chief Marcella refused to remove to the Flathead Reservation, though one band of sixty-three under Chief Michael removed to that reservation after Michael agreed with the government to sell his lands in 1887. Michael's band feared that if they did not remove there, they would be forced onto 
$\nabla$

the Coeur d'Alene Reservation. A white traveler among the Lower Kalispels noted that, though they were a small tribe, they had powerful relatives and backers among other tribes, who would not let them be "eaten up by their enemies." In 1890, large numbers of whites entered the Pend Oreille country. By then the natives were concentrated on the eastern shores of the Pend Oreille River (opposite Usk, Washington).

As the twentieth century approached, nontreaty (non-reservation) Lower Kalispels were displaced by white settlers. The Indian commissioner in 1895 therefore ordered their lands surveyed and legal descriptions filed with the General Land Office. Most Kalispels did not live on the lands surveyed for them, but in communal enclaves that moved about on these lands. A problem arose when it was realized that the Northern Pacific Railroad had been granted odd sections on which some of the Kalispels lived. In 1906, Congress gave the Northern Pacific lands in lieu of 2,711 acres occupied by Kalispels, thus minimizing the threat of their removal to a reservation. Continuing white pressure for land in the early twentieth century precipitated renewed surveys and allotting. Since the time of the 1895 surveys, deaths of over a score of Kalispels had been offset by their increased numbers; hence only forty acres of agricultural or eighty acres of grazing lands could be allotted each member. In December 1911, the Spokane agent was ordered to allot them, following the resurvey the next year. Individual trust patents were not issued, since many allotted lands were withdrawn for power-site development on the Pend Oreille River.

Nevertheless, a reservation, as noted, was established in 1914 on the allotted land, even before land patents were issued. The first patents were received in May 1924, and the remainder nine years later.

With but two of the thirty-eight members voting against it, the Kalispels accepted the Indian

\section{Whitefish Fishermen of the Kalispels}

Each fall, the people living in the valley of the Camas, journeyed to Priest Lake to gather their winter supply of whitefish. The people packed up their belongs, placed them on horses, and headed up the trail over North Baldy.

Upon arriving at the fishing camp on Priest Lake, the people erected teepees and joined the people from other tribes in the festivities of the camp.

The fishing camp was under the direction of a camp master. An older man, with much experience in whitefishing, the camp master set the rules and directed the activities of the camp.

The bulk of the fish were caught with fixed traps. The traps made of willow bark, and permitted the fish to enter but not to escape. The trap was set in waters where the whitefish were known to be.

One spot fished by the people was known as Indian Creek. Here the traps were set across the mount of the creek and the fish swam into the creek and into the trap.

Each day the traps were checked and the fish removed and taken to the fishing camp.

At the camp, the camp master placed the day's catch in a huge pile. Then he distributed the fish equally to all parties living in the camp.

The fish were cleaned and smoked in the village smokehouses. After smoking the fishmeat was dried and stored for winter use. When the first snow appeared on Old Baldy, the people packed their belongings and headed for home with the horse travois leading the way.

In their village, in the Valley of the Camas, the people would spend the winter. In the spring they would be off again in search of the bitterroot. 
Reorganization Act of 1934 and organized. In 1939 , they chartered themselves under the new constitution (approved in 1938) as the Kalispel Indian Community, of which the governing body is the Kalispel Indian Council. Their constitution was revised on July 27, 1967. In 1974, the Kalispel federal tribal jurisdiction was transferred from the Northern Idaho Indian Agency at Lapwai to the Spokane Indian Agency at Wellpinit.

In the course of seventy-four years, 1850 to 1924 , the four million plus acre aboriginal range of the Kalispel was consumed by railroad grants and settlements made without the benefit of due process. The one formal Kalispel treaty effort, stemming from the Sandpoint Conference of 1887 , which had dubious tribal consent, was never ratified by Congress. The land was simply taken and parceled out in railroad and homesteading grants which ignored tribal rights. In 1963, Kalispel claims under the Indian Claims Act were settled and the United States paid approximately 75 cents per acre for Kalispel ancestral lands which had been taken without consent. The tribe received approximately 68 cents per acre in net proceeds after attorney fees in compensation for the seizure and appropriation of its traditional lifestyle, wealth and heritage.

In 1967, the Senate Interior Committee requested legislation terminating the Kalispel. With the assistance of Congressman Tom Foley, efforts to terminate the tribe were canceled.

\section{THE RESERVATION TODAY - NATURAL RESOURCE MANAGEMENT}

While the history of the Kalispels' relation to Euro-Americans has often been tragic, tribal government and tribal resource managers are regaining control of tribal destiny through a unique marriage of traditionalism and scientific modernism.

When the dams at Albeni Falls and Box Canyon were installed several years ago, operations changed both the Kalispel way of life on the reservation, and the watershed as a whole. In the 1950s, the dams changed the river from a world-class trout fishery to a warm water slough. Following installation, bass were introduced, nearly completing the shift away from the old subsistence base.

Other developments - mainly logging and agriculture - also degraded and changed local habitats, mostly with little or no input from the tribe.

In the past ten years, the Kalispel Tribe has been in the process of upgrading its natural resource management, and making certain that it is an equal partner with local, state and federal agencies in managing the resources.

The Kalispel Tribal Council sets the general goal, which is defined as "protecting and enhancing the entire ecosystem on the reservation and adjacent areas." Based on that directive, the resource department recommends programs or specific goals and objectives tied into general goal statement. Each part of program is explained to council; if the program fits into its direction, the Council adopts it.

Tribal resource managers have identified several objectives, one of the most ambitious and far-reaching being habitat management on the Flying Goose Ranch. In 1989, the 480 acre ranch, which fronts the Pend Oreille River, came up for sale. The tribe submitted the idea of buying it to the Northwest Power Planning Council as on-site mitigation for impacts to the river from operation of Albeni Falls Dam. The tribe held a buy-option on the land for four years, during which the price dropped from $\$ 1$ million to $\$ 300,000$. At that point, the Bonneville Power Administration purchased the land, turning it over to the tribe for management.

The primary direction of the Flying Goose Ranch management plan is restoration of the land to waterfowl and target species production. Implementation began in 1993 with initial habitat evaluations. Eventually the project will mitigate 


\section{The Kalispel Camas People}

Over the years it became the custom of the Indians of the Northern Rockies to gather at Priest Lake to fish for the whitefish. People from various tribes came from as far away as present-day Montana. The event was an important social gathering for the tribes. In addition, it provided a much needed supply of winter food.

It was at the time of the gathering at Priest Lake, that one fellow decided to go up the mountain west of the lake, to see what was on the other side. He returned and reported that there was nothing but water on the other side of the mountain. So two of them men traveled over the mountain to see the water.

To their surprise, they found that the area was swampy and the blue that the first explorer had seen was really half water and half blue flowers.

Digging up the blue flower they found it had a bulb growing beneath the ground. They tried eating it raw, but it didn't taste good. They tried cooking it a number of different ways, but it still didn't taste good. Finally, they cooked some underground and it tasted delicious. Gathering some, they returned to their camp at Priest Lake.

At the fishing camp, to demonstrate their find, the men dug a cooking pit. The pit was about one foot deep and several feet wide.

Then the men placed sticks in the pit, laid rocks in the pit, and started a fire. When the fire burned out the ashes were removed and the hot stones left in the pit.

The rocks were first covered with dirt. The camas bulbs were placed on the leaves and then more skunk cabbage was placed on the bulbs. Dirt was then placed over all the layers.

Logs, some eight to ten inches in diameter were placed over the pit and a fire started. The fire was kept going for twenty-four hours. The camas bulbs were checked to see how they were cooking and a small fire was built the second night.

At the end of the second day of cooking, the camas bulbs were removed and spread out to dry in the air. Later they were stored in baskets for winter use.

Because the camas tasted so good and because of the abundance of the plant, some of the people traveled from Priest Lake to the Camas Valley.

Once there, they set up their villages and harvested the camas bulbs. Today, their descendants still live in the Valley of the Camas, and they are called Kalispels, which means "Camas People."

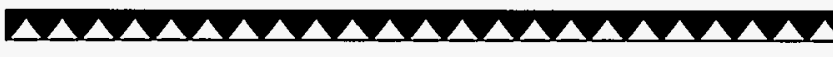

for 5 percent of the total losses from Albeni Falls to muskrat, mallard duck, Canada goose, yellow warbler, white-tailed deer and blackhat chickadee. Under the management plan, a Habitat Evaluation Procedure (HEP) identifies important species and their associated habitat as a way to manage habitat, rather than managing in a species-directed manner. For instance, once the chickadee is identified as a species of local importance, the managers identify how much canopy the chickadee needs, how high the canopy needs to be, etc. This information is fed into a Habitat
Suitability Index (HSI). Each acre is evaluated in terms of its HSI. This allows for managing both the quality of the habitats, as well as their quantity. In the past, mitigation efforts were often marred by land-swaps that related only to the numbers of acres swapped, rather than their suitability as habitats.

Thusfar, tribal managers have realized benefits by taking a hands-off approach, increasing wetlands by a factor of three with only minor adjustments. They are also experimenting with riparian zone restoration, using several 
different designs, since dam operations have produced fluctuating flows and elevations in the river that have led to bank-sloughing.

Resource managers, working with Tribal Council, are attempting to enhance and restore habitat, and also to do it in a way that involves, and is relevant to, traditional culture. The tribe is exploring the idea of adding to the Flying Goose Ranch a Cultural Resource Interpretive Center that would allow both the people of the reservation and people to see what is being done with the land, and how that ties into traditional land use. If the Center comes to fruition, an exhibit on riparian zone restoration would include a discussion of traditional Kalispel sturgeon-nosed canoe construction, for which birch bark served as cover, while the structural elements were usually of maple - both riparian species. Visitors may see how, traditionally, cambium from trees was used for smudging, and how the grassland habitat provides camas, an important food source.

The tribe is also using resource management as a way to train and employ young tribal members. Managers interact with the local public school district, and have career days at the Flying Goose Ranch. Meanwhile, the tribal anthropologist is considering ideas for language preservation, including reintroducing the traditional language back into report writing by relating biological terms to their equivalent traditional terms.

\section{An Elder Speaks}

My parents lived in the household when I was growing up. My parents lived there, my brother and my sister, and my grandfather. My grandparents on my mother's side taught me spirituality. They talked to me, and taught me to respect all the animals, to respect everything that flies, everything that crawls, everything that swims. They taught me not to hurt them, not to torture them, because someday they may turn around and help you. I never killed anything. I even hate to kill a spider; and it's brought me good luck. I catch a spider and throw it outside. Everything has a meaning to it for survival. Even the trees: don't be chopping them down if you're not going to use them.

In the morning my parents and grandparents got up and prayed for everything that was going to happen that day. My grandmother went to dig camas the first time, she'd go down with the ladies, and they would pray, bless the ground and the food. They did this for the camas, the huckleberries, the wild strawberries. Everything, they'd take a little handful and they'd have the chief bless the food wherever they gathered. The chief did everything for the people. He was a political leader and a spiritual leader. The chief was my grandfather, and when he died my grandmother blessed everything. Anybody who was a spiritual leader could do it. It didn't have to be the chief.

My family was spiritually involved in everything. They believe in the animal spirits, although they became Catholics. I was raised in both religions, and I still believe in both. My grandparents taught me the Indian religion. Once a year we do the Medicine Dance, to cleanse your whole body, and the sweatlodge. We all go to the sweatlodge to pray to Grandfather...not to God...to Grandfather. It helps me realize what I am. I started sweating at 17 or 18 . You can pray to Grandfather, you can pray to God, it's all the same. Grandfather created the world. I don't have any trouble practicing the two religions. I can go either way. The priests couldn't take the religion away from me. My parents told me that when people get together to do spiritual things, I 


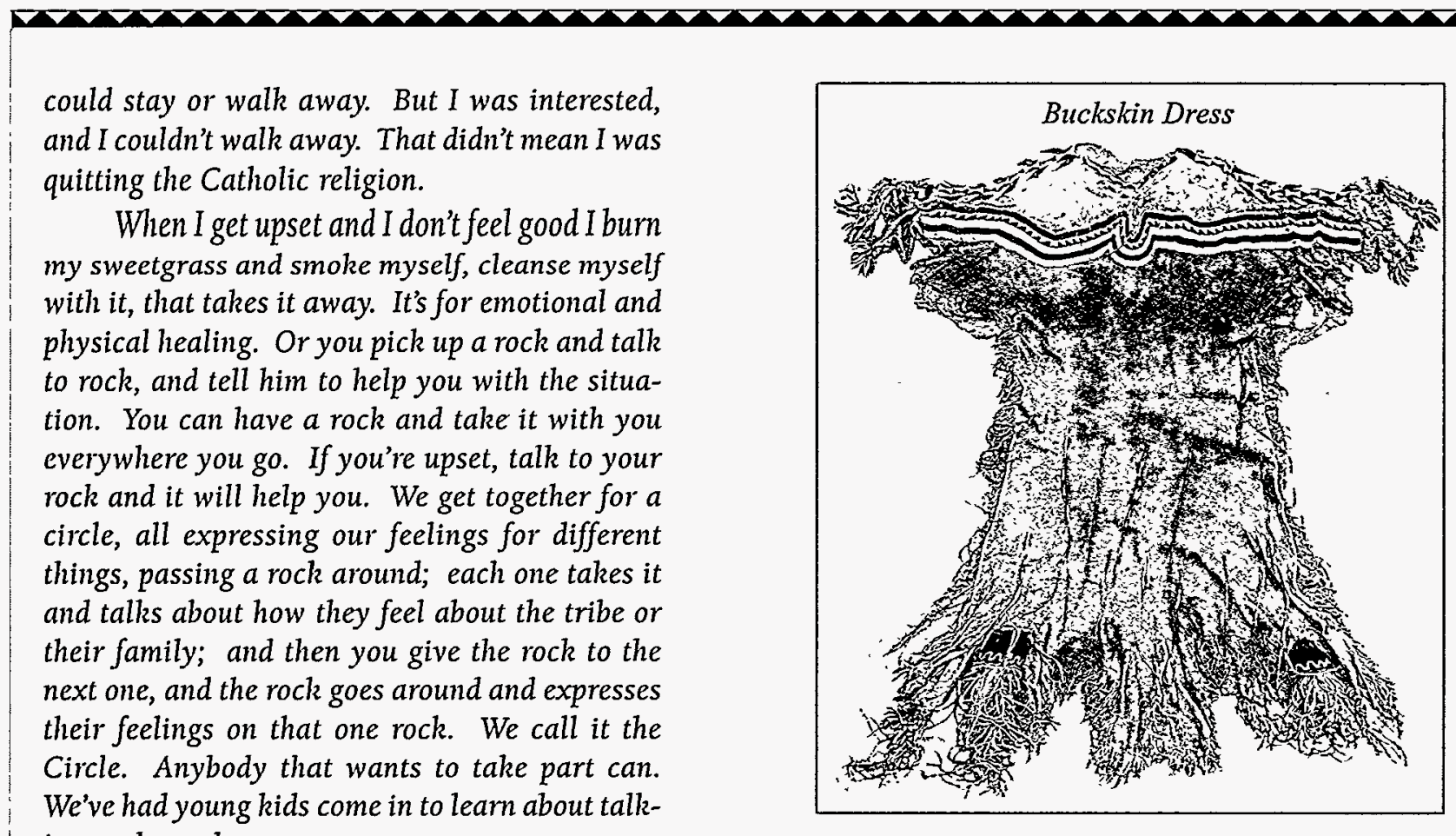
ing to the rock.

The Kalispel lived up and down the river when I was growing up. They'd hunt and fish around Priest Lake, and trade for their furs around Hope, Idaho. My mother said that the menfolks would have piles and piles of fur, beaver, otter, whatever. They'd trade for flour, blankets, sugar, all kinds of clothing.

When I was growing up my family would not give up their land on account of the river; the river was their soul, their pride...they were river lovers. My folks would go to Priest Lake for a month or two and fish for whitefish. That was where they got their whitefish. The camas was another reason they would not give up the river: Every year they would pick the camas, the huckleberries, the cattail root. They had the wild mint from the river; and the onion, and the carrot, and the little island that is underwater now, they trapped for fur. That's why they loved this place. They were asked to move, but no. They were offered a hundred and sixty acres to move, and they said no. Finally they took forty acres to stay, because they didn't want to give up this river.

They got everything right here that they need: fishing, hunting, gathering the roots, they didn't want to give it up. They were told, we will move you to Montana; but once they set foot here, they were not going to move.

Ilove being what I am, being Kalispel. Only thing that my grandfather told me was, "Don't ever let go of what you got. Where you were born is where you'll be for the rest of your life. If you have children tell them never to give up the reservation or sell it or whatever."

I love being a Kalispel. Old chief Masselaw divided his people. When they moved the church in 1884, half the Kalispel went with the church, which is now located in St. Ignatius, Montana. The other half stayed, and my grandparents were part of that group. We're not going to leave this area. They decided to stay because they loved the area, everything was within their reach.

I'm proud of my daughter. She's a traditional dancer and she speaks the language, like her grandparents taught her. She's strong for keeping up the old ways. Once a year we have our annual powwow. In February we have our annual sobriety powwow, to keep everyone sober. We have dinner with speakers, and non-alcoholic things. We have a war dance across the river. We have big turnout, people from different reservations who come to support our powwow. Its very powerful; you realize how bad you are inside, and you're trying to cleanse yourself; it makes you feel good.

Alice, Kalispel Elder 


\section{KOOTENAI TRIBAL PROFILE}

\section{LOCATION AND LAND BASE}

Kootenais that lived near Bonners Ferry, Idaho refused to move to the Flathead Reservation in 1859. In 1895 individual members near Bonners Ferry received allotments from the Government. Following years of claims for compensation, the Kootenais received compensation in 1960 , and in 1974, after declaring war on the United States, they received a reservation at Bonners Ferry.

Land Base: 12.5 acres total

\section{ENROLLED MEMBERS}

160

\section{LANGUAGE(S)}

The Kootenai language is an isolate language, not recognized as a dialect of any larger language family. The Kootenai Tribe of Idaho is closely related to the Kootenai bands that reside on the Salish-Kootenai Tribes of the Flathead Reservation and in southern British Columbia.

\section{ECONOMIC BASE}

Tribal casino at Bonners Ferry, Washington.

TRIBAL GOVERNMENT

Non-IRA (Indian Reorganization Act)

FEDERAL TRIBAL JURISDICTION

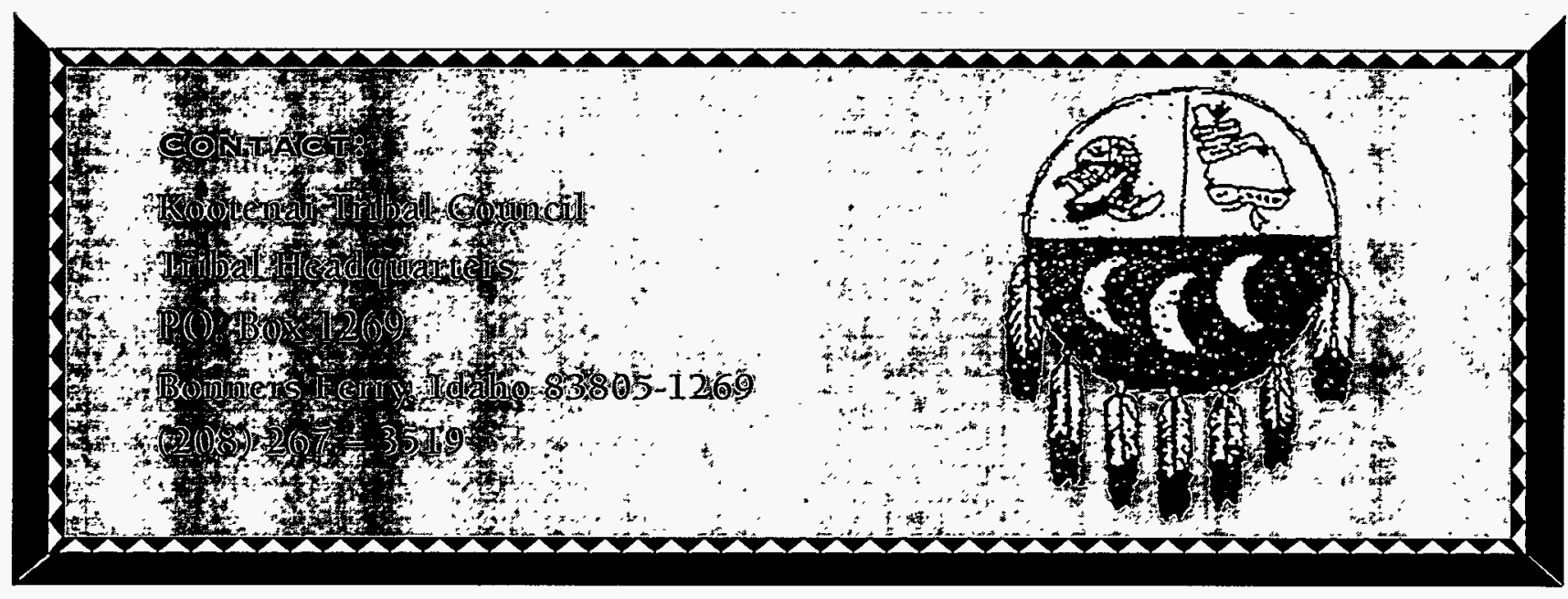




\section{KOOTENAI}

\section{BEFORE THE BEGINNING OF TIME}

Kootenai Elders and oral historians say that much of their very early history, including Creation and the beginning of time, is so uniquely Kootenai and so sacred that it cannot be shared with outsiders. They have consented to provide the following information:

It's just like in your Bible. There is a Creator who made the world. You call the Creator God; He told us to call him Nupika.

The Creator-Spirit was in everything, and there were no people. Then He decided to make human beings. He made different people for different places. He made the Kootenai People for this place.

When $\mathrm{He}$ was ready to put us on earth, $\mathrm{He}$ told all the spirit-creatures they would have to move above, because the people were coming. Only their forms and their songs could stay behind, to help the people.

And then, the same as with Moses in your Bible, $\mathrm{He}$ told us Kootenais our rules, our Commandments. Here is part of what He said:

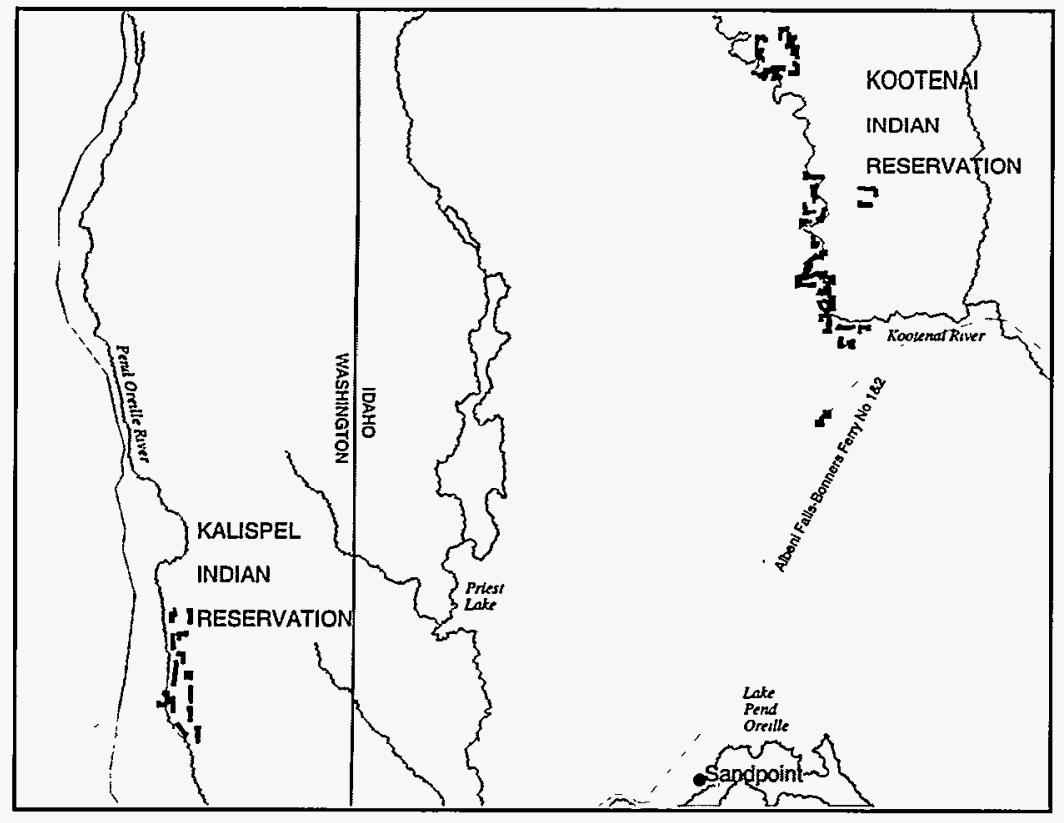

"I am your Quilxka Nupika, your supreme being. I have no beginning and no end. I have made my Creation in my image a circle - and you Kootenai people are within that circle along with everything else in my Creation.

"Remember that everything in my Creation is sacred, and is there for a purpose. Treat it well.

"Take only what you need, and waste nothing.

"Don't commit murder.

"Respect and help one another.

"Cherish your children and your old ones - they are your future and your past.

"Your word must always be good. Never lie, never break a promise.

"At all times, pull together - act with one heart, one mind."

Then He told us the ceremonies and prayers we could use to get help when we need it. You have your angels and your saints, who help you. We Kootenai People have our Nupikas, who help us.

Finally, Quilxka Nupika told us His most important commandment. He said:

"I have created you Kootenai People to look after this beautiful land, to honor and guard and celebrate my Creation here, in this place. As long as you do that, this land will meet all your needs. Everything necessary for you and your children to live and be happy forever is here, as long as you keep this Covenant with me. Will you do that?"

And those first Kootenai People promised to keep the Covenant with the Creator, just the way the Jews did in the Old Testament. So, He put us here, in our Kootenai Aboriginal Territory.

And that's how time began. 


\section{The PeAceful MiLlenium}

Kootenai Oral history then continues:

After time began, for thousands and thousands and thousands and thousands of years, we lived here in peace and harmony with Creation and each other fulfilling our Covenant with the Creator.

There were many thousands of us living throughout our Kootenai Aboriginal Territory. Much of the time we lived in small family groups in the areas best suited to the talents and tastes we had been given by the Creator in the beginning of time.

Some lived deep in the Rockies, close to the plains: They were the master buffalo hunters and the guardians of our eastern boundaries. Those days, we lived peacefully with out Blackfeet neighbors. We respected each others' rights and customs, and shared certain resources. The land was too sacred to fight over.

Some of us lived in our heartland. There we thrived on the abundant deer, elk, and moose, and cared for and harvested the bitterroot, camas and tobacco which grew on the dry lower hills.

Some of us lived along the Kootenai River and the lakes that feed it. Here we used the beautifully designed Kootenai canoe to tend the waterways and harvest those waters. We hunted and utilized the mountain caribou, which was so abundant before the strangers came. Here, too, we lived peacefully with our neighbors, the Salish and $\mathrm{Nez}$ Perce. The Kootenai Tribe of Idaho is one of the surviving groups of the River Kootenai People.

Each family group had its own places to hunt, to fish, to gather berries and fruits and vegetables; to obtain the materials they needed for tools, clothing, and shelter, and healing.

Each person in each group had their particular tasks and responsibilities. From the time they were little children, every person knew they were valuable.

All were cherished and respected because all were here for a reason.
Today, we might consider that life harsh and difficult. We traveled long distances, we worked hard in every kind of weather. We had no cars, no furnaces with thermostats, no electric appliances or TVs, no steel knives or repeating rifles. It's true, everyone had to work very hard, those longago times.

But we had no prisons, no mental hospitals, no treatment centers; no welfare offices or food banks or old folks' homes, either. We had no need of them.

It was hard work, but life was filled with joy and laughter. When everyone pulls together, nothing is too difficult.

At certain times of the year we came together in larger groups for important sacred purposes. At those times there was much joy - people would visit and exchange presents and the young ones might find the one they were going to marry.

Always we kept the commandments the Creator had given us. Always we honored our Covenant with Him. So life was very good. We were happy, here in our homeland.

From the beginning of time, that's how it was here in the Kootenai Aboriginal Territory, for thousands and tens of thousands of years.

\section{THE WIND BEFORE THE STORM}

For all those thousands of years we were busy and healthy and happy, living according to our Kootenai ways.

And then about five or six hundred years ago, one of our people had a vision. It was a warning, like the sudden wind that blows before a summer storm. This is how it went:

"Strangers will come.

"They will have pale skin, blue eyes, and yellow hair. They will be very clever and very powerful. There will be many, many of them, and more and more will come. They will be very, very destructive.

"They will be too many, too powerful, and too destructive to fight against. 
"Eventually, they will become so many, so clever and powerful, and so destructive, that they will destroy themselves.

"When the time comes, unless we Kootenai People have hept our Covenant with our Creator, these strangers will destroy us, too."

As word of that warning spread through the Kootenai Nation, we felt a terrible dread.

But when we first saw them, there were only two or three of them walking frightened in our mountains. They did look strange! Their faces were covered with hair, and we wondered - were these the strangers we had been warned about, or were they some new kind of animal?

Those first ones turned out to be fur traders. They were the first drops of rain in the coming storm.

After that they came more often. At first they came to trade for our furs. In exchange, they gave us things from their clever technology - steel knives, axes and needles, iron pots, bright woven cloth; woolen blankets, glittering colored beads.

Then a Blackrobe came with a Bible talking of a new, very powerful God. That was the Jesuit Father DeSmet. We let him put up a cross on a hill above the river.

But we began to hear of terrible things happening far to the east - wars in which people were actually killed, even women and children and the old. And not just killed, but made to suffer first. We had no words in our language for that. Our Blackfeet neighbors had become our enemies, as the buffalo grew scarce and they blamed us. We had to fight them.

More and more of the strangers came, wanting to cross the river. A lot of them were gold hunters from California and the East; wild, strange, cruel men, they were. We had to invent a word for rape. We began to dread their coming.

We knew the warning was true, and we felt fear.

\section{THUNDER IN THE EAST}

In 1855, your Head Chief in Washington, D.C., your President, sent Governor Stevens to make treaty with all the tribes out here. They met at Hellgate over in Montana.

Our Kootenai Head Chief, Michel, sent his men to hear what Stevens had to say. When they returned and told him about the plan to put all of us on a reservation in return for giving up all of our Aboriginal Territory, Chief Michel was horrified. He said that would be impossible. It would be against our Covenant with the Creator.

So no Kootenai ever signed that Hellgate Treaty. Someone forged the Kootenai marks on it. We kept our Covenant.

Here in what you call Idaho, for a few more years we continued to live as we had always lived along the river, traveling to our hunting grounds, berry patches and sacred places, according to the seasons.

When the surveyors came from the International Boundary Commission, we took them and their equipment across the river. We shared our food with them and showed them safe trails to follow.

We helped them, and then they drew a line through the middle of our house, and said we couldn't cross it. You call that line the U.S.Canadian Border.

Because of that border, and the epidemics that killed so many of us, the Kootenai Nation is now reduced to seven communities - five in Canada and two in the U.S. Although we are fewer in numbers now, we are still strong in spirit and will. And we are still the Kootenai Nation one people, one heart, one mind.

We learned that these strangers treasured the metal gold - and we had no use for it. So twice we gave them some and showed them where it came from. Their people got very rich from those two mines, but they never shared the wealth with us. Mines do a lot of damage; they are too destructive. So we never showed anyone else 
more places where there was gold. The earth is too sacred to be treated that way.

Finally, in 1864, our Chief Abraham sold the ferry rights to Mr. Bonner and his two partners. He didn't sell it for the money, but to prove that it belonged to the Kootenai Nation. We were beginning to understand the strangers' ideas of property and ownership.

In 1889, Major Ronan came and looked at all the places where we lived along the river. He promised us that those lands would always belong to us. But strangers were coming with guns and taking it from us.

It was less than fifty years since that Hellgate meeting and already many, many, many of us had died. It took us awhile to realize that those fine woolen blankets carried smallpox, the disease that killed us in such numbers. We stopped using them.

Even though we were much fewer than we had been, we were using the land along the river all the way from east of Bonners Ferry to the big lake in what you call Canada. It worried and upset us to be driven away at gunpoint. So we went to the Indian agent over at Colville and asked him to help us keep our lands. He said he would, because we had a right to those lands under U.S. law.

"Under date of April 15, 1889, late United States Indian Agent Gwydir, of the Colville Reservation Wash., reported that certain non- reservation Kootenai Indians, located in north Idaho, were in destitute condition; that the whites planning for or already engaged in mining operations were overrunning the country occupied and claimed by them; that they had driven away the game, which, up to that time, had constituted the principal support of the Indians, and that 'Isaic and Melisca,' in their appeals for relief, begged that 'Washington, the Great Father,' be informed of this state of facts. Subsequent correspondence relating to these Indians shows that they number some two hundred and eighteen; that they are strongly attached to their old homes, and that they earnestly desire to secure titles under the provision of the fourth section of the general allotment act."

Report of the Commissioner of Indian

Affairs - 1890

We tried to explain to the white men that these lands along the river had been ours to live on since the beginning of time, and they would have to go someplace else. They sent for their U.S. cavalry.

We were afraid of the Cavalry. We'd heard what they did to Joseph and the $\mathrm{Nez}$ Perce, the Northern Cheyenne, and the Sioux. We didn't want our women and children massacred.

So we let them herd us down from what you call Copeland to Bonners Ferry. Some, north of that, tried to go to Canada. Major Ronan came again to talk to us. He told us we had to move to a Reservation. He got very angry when we tried to explain why we couldn't. He couldn't understand about our Covenant. 
A few who had relatives over in Montana agreed to move.

\section{GOOD INDIANS IF THEY GO}

A proposition to Move the Kootenais to the Flathead Reservation

"Major and Mrs. Ronan will shortly visit the Indians in the Kootenai valley to arrange with them for their removal to the Flathead reservation. The Major was there two years ago and offered the band their choice of reservations to go. They preferred taking land where they were in severalty. They never secured title to it, and this summer white settlers rushed in and jumped it. In July a delegation of them visited the Flathead agency and asked permission for the band to be removed there. Now Major Ronan goes to them with authority to remove them to the reservation at once if they desire to go. As Chief Ameas' band of Kootenais is already there, there [they] will probably....prefer this to any other reservation."

Bonners Ferry Herald, October 31, 1891

Most of us stayed, to keep the Covenant. We thought if there was just a few of us, they would be satisfied. In 1892, Major Ronan came back and allotted our lands again, to be ours forever in trust.

\section{ALLOTTING LAND TO INDIANS}

Maj. Ronan Arrives and

Commences the Work

"United States Indian Agent Peter Ronan of the Flathead Reservation, Montana, is now at Bonners Ferry, under special orders from the Department of the Interior, to allot lands in severalty to certain Indian families, who have concluded to remain upon the land they have always claimed and occupied....Major Ronan informs us, that none but heads of families have applied to him for their homes. It will be seen by his instructions that children are entitled to land as well as heads of families, but the Indian in chief on Tuesday last, informed the agent that they were thankful to the government for giving such privilege under the law, but that they would not now ask for allotments to their children, and only a few heads of families who now occupy and have always occupied the land, would take advantage of the law."

Bonners Ferry Herald, October 19, 1892

That newspaper story isn't exactly true. We understood that we had to have enough land for the generations unborn. But Major Ronan and your government wouldn't give it to us. So we took what we could get, and hoped that was the end of it.

The Blackrobes tried to persuade us that their religion was the only true one and ours came from the devil. For a little while, we believed them. We tore down our sweatlodges and burned our medicine bundles, and went to church every day.

Within a year, epidemics of measles and diphtheria struck us. Here in Idaho, more than one hundred people died in twelve months. From this, we knew the Blackrobes were wrong. Their religion was not right for us. We renewed our Covenant with our Creator.

We could see that we would have to learn to live in this strange new world your people brought to our Kootenai Aboriginal Territory. And we could see that that was going to be very difficult.

\section{The Deluge Strikes}

Major Ronan told us we would have to farm our allotments. The Government promised to help us, to give us seeds and cattle and equipment. But the help never came. A few years later, they came back and made the allotments smaller. They 
said we weren't farming, so we didn't need all that land.

We lost more land because settlers would move the surveyors' posts that marked our allotments.

"...the indian [sic] allotments on S. side of the Kootenai River, as shown on the accompanying plot of the township, were protracted from a survey made of the claims by me before the destruction of the corners, which has been done by the white settlers who have placed quite extensive improvements on most of the claims, as noted in the body of these notes...."

Excerpted from Surveyors' Notes, 1893

But we continued to struggle to hang on to our land. We cut hay and sold it, and bought our own cattle and seed. Where the allotments adjoined we farmed together, helping each other the way we've always done things. We had gardens.

We built houses out of logs close to the church, and sent our children to school. At first we had to send them to the school at the St. Eugene Mission, up in Canada. That was a cruel place where the children were brutally punished. It taught a lot of them to be ashamed of being Kootenai Indians. The Blackrobes and the school taught us to hit one another and be cruel to our children. They called it "discipline." We still have the whip the priest gave our Chief to use, to punish people who did wrong.

No matter how hard we struggled, we kept on losing our lands. Some we lost when people died. If any of the heirs were Canadian - and they often were - that land couldn't stay in trust. Canadian Indians had to pay taxes on land here, not just in the future but for three years back. Often they had no money to pay with, so they'd sell for what they could get.

Some people were afraid they'd lose more land if they couldn't farm it, so they would lease their allotments to the farmers.
The white men had begun to talk about diking the river so it wouldn't flood the land, and draining the marshes. They had figured out how rich that land would be if they could keep the water off it. To us Kootenais, it was rich already, with many kinds of fish and waterfowl and water animals. It gave us plenty to eat, and we were satisfied with it.

They went ahead and diked and drained an area on the southwest side of the river, and they called it District I. It was a success - the crops were good. And the land traders who had bought the land cheap as swamp made a lot of money when they sold it dear, as prime farm land. So they set about forming more drainage districts.

The problems came when they wanted to make drainage districts in places where there were a lot of allotments. The U.S. government wouldn't allow the allotments to be taxed to pay for the dikes.

Some of those land speculators weren't exactly honest. They'd tell some Indian that those papers were a lease, and the Indian would sign it. Then it would turn out to be a bill of sale. So we lost more land.

But it wasn't enough to solve the problem of the drainage districts. Finally, in 1926, the senator from Idaho got a bill passed through both Houses in Washington, D.C., that allowed the Secretary of the Interior to sell the allotments and use the money to pay for the diking. That bill said that if there was money left over, the allottee could use it to buy five acres of other land, in trust. If that person wanted more than five acres, they would have to pay taxes on the rest.

We Kootenais didn't like that bill. We didn't want to sell any of our land, it was all we had left. We tried every way we knew to prevent that sale.

But it happened anyway, in 1928.

\section{DISASTER AND SORROW}

Nothing in our whole history had prepared us for the things that had happened in the first fifty years of this century. 


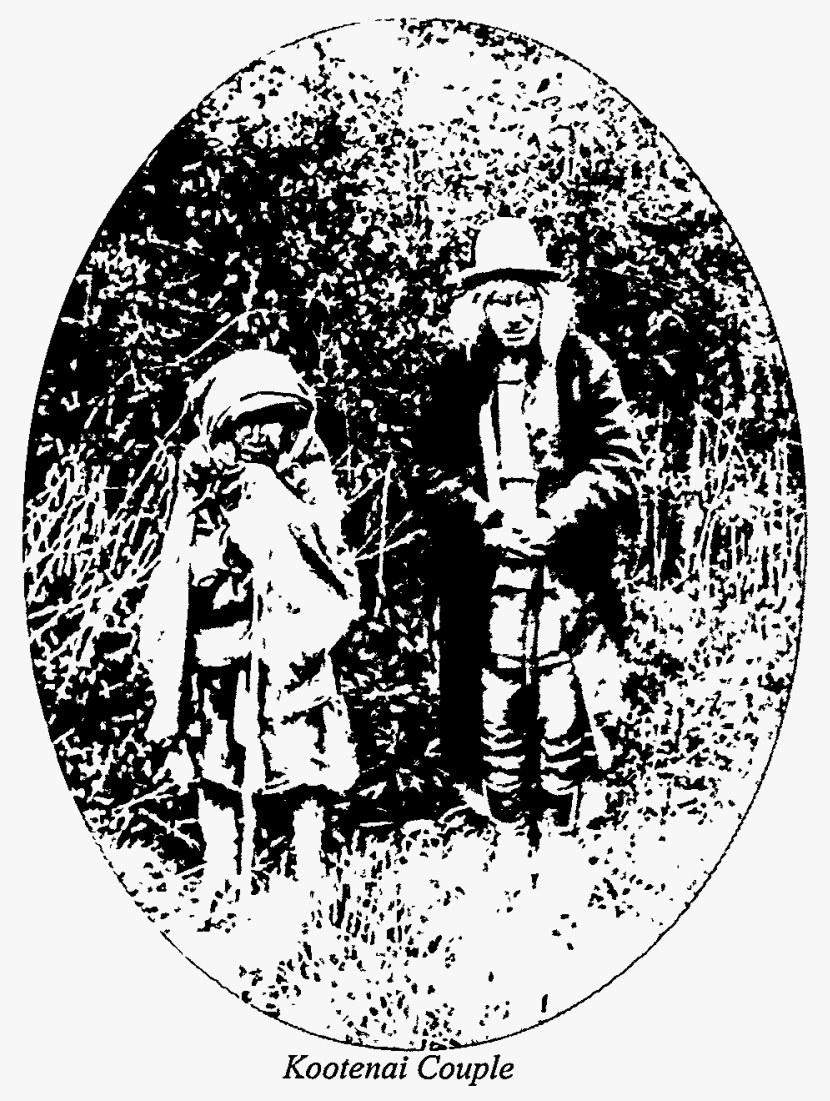

Our word had always been good - we didn't lie, and we kept our promises. Now we had to deal with people who didn't tell the truth and seldom kept their promises.

From the beginning of time we had respected each other and everything in His Creation. Now we had to deal with people who didn't seem to respect anything but money and the power money could buy.

Always we had been strong and healthy. Before the strangers came, about the only things any of us died of were accidents and old age. Our healers were skillful and effective and sickness was very, very rare. Now strange terrible new diseases were killing us off so swiftly our healers had no time to learn to treat them - first smallpox, then measles and diphtheria, then tuberculosis and the bad water killed our babies.

We had been a proud, strong, numerous people, living well in our beautiful Kootenai Aboriginal Territory at peace with our neighbors and ourselves.
Those early strangers noticed how strong and happy we were, and they wrote about us:

"The Kootenay Indians were, in the days I refer to....one of the most interesting families of the North American aboriginal population....

"The Kootenays were a tribe practically untouched by the baneful influences of the aggressive civilization of the West. They had no reservation....they received no assistance from the Government....they lived entirely upon the products of their rivers, lakes, and forests; they spoke a tongue unknown to their next neighbors; they kept strictly to themselves....they were peaceful....

"The Kootenays were a fine, manly-looking race.... They had one noticeable peculiarity...it was their merry and laughter-loving disposition."

From Baillie Grohman: "Fifteen years of Sport \& Life"

"The Kootenays were decidedly the finest race of Indians met with during the progress of the Commission, though but few particulars could be learnt about this very interesting tribe, which, speaking a widely different language and walled in by high ranges of mountains, is entirely isolated.... The Kootenays bear the reputation of being brave, honest, and truthful, and prided themselves on the fact that no white man has ever been killed by them."

From Report of the English International Boundary Commissioner, Sir Charles Wilson

Now it seemed as if none of the old trusted ways worked any more. It seemed as if the new god the Blackrobes talked about was indeed more powerful. We began to doubt ourselves.

When people called us dirty savages and ignorant heathen we began to believe them, even though it didn't feel like the truth.

When the government told us we were mere simple children we accepted that. We had no choice. The government was giving away our aboriginal territory. It gave us allotments and then took some of those away, too. It controlled what we could do with what was left. It decided where we could live, where we could travel. The 
government passed law saying our religion was wrong and illegal.

At the same time, your technology was so clever, so attractive. You had so many things that seemed to make life easier, more pleasant. It was very appealing and very confusing. We found ourselves lost, in our own homeland. That had never happened before, ever, since time began.

Besides clever technology and killing sicknesses, the strangers brought us another, very terrible thing: alcohol.

At first, though it tasted awful, we liked how it made us feel. It made us briefly happy and eased the pain of our losses. By the time we realized it was a poison that made us crazy, and sick in our souls, it was too late. Many of us were addicted to it.

Once a person becomes an alcoholic or an addict, nothing else matters to them. Not family, nor children, nor self-respect, nor truth, nor even God. Only the next drink. Alcohol takes control.

Alcohol was illegal for Indians in those years, but there was always some white man happy to get us our next bottle. It's easier to cheat a drunk Indian than a sober one.

Even by the time of the forced sale in 1928, alcohol had taken control of some of our lives. After that forced sale, it seemed for a time as if there was no hope. Alcohol helped us forget.

Between struggling to stay alive at a time when it was almost impossible for an Indian to get a job, and struggling to hang on to our lands when it seemed like the whole world wanted us to lose them, life was hard. Sometimes alcohol seemed to make it easier for awhile.

We even tried to get a reservation - we thought that might help us hang on to our land. We always got the same answer: If you want to be on a reservation, move to the Flathead Reservation.

While all this was going on, another problem started: The State of Idaho decided that we couldn't hunt or fish in our Aboriginal Territory any more

\section{S - White Men Supply Liquor to Indian}

"...Ignatius BigHead was taken from town to the sheriff's officer for and hour Sept. 20. He was intoxicated told who the whiteman was that bought them the Whiskey. they let him go James Randall who bought. 2. qrts of whiskey for Ignatius BigHead and Batist Cutsack (Baptiste) was arrested by the county sherriffs Sept 22....Fred Myers. a. white man was arrested on March. 24. for selling liquor to Indians had his trial on the .26. will have his sentence on the .27 sentenced Mr. Myers 30. days and $\$ 50$ fine. 30 days in county jail...."

Excerpted from the Diaries of Simon Francis

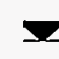

because we didn't have a reservation. They said we were harming the animal and fish populations.

That was hard for us to accept. We'd been taking as many animals and fishes as we needed ever since time began, and even when there were tens of thousands of us, there was plenty to meet our needs. We never took more than we needed, and we used every bit of what we took - we wanted nothing. We gave thanks, as our needs were met. And no one ever went hungry.

It was after the strangers came, more and more of them everywhere, that it began to change. The mines and the logging scared the animals away. The strangers were greedy and foolish, they'd shoot an animal for one meal and leave the rest on the ground. Some of them wouldn't bother with the meat at all - they'd kill just for the horns, and leave the meat to rot. That was wrong. The animals ran away, those that were left alive.

It was the same with the fish. Logging and mining messed up the streams so that the fish couldn't live in them. The diking spoiled the places along the river and that Grand Coulee Dam 
stopped the salmon from coming. There were fewer and fewer fish to be caught.

But none of that was our doing. We needed the animals and fishes for food.

Compared to the long-ago days, there was hardly any of us Kootenai People left. It didn't seem reasonable to us that the state could stop us from feeding ourselves from our Aboriginal Territory. But they said they could.

It got to the point where we would have to choose between seeing our families go hungry because we didn't hunt and fish, or seeing them go hungry because we did and got sent to jail for it.

It took a long time and a lot of court cases before we proved that the state was wrong, and we have the right to hunt and fish in our Kootenai Aboriginal Territory. In the mean time, there wasn't much to eat.

We were still living in the one-room cabins our grandfathers had built years before - nobody had money to build better homes. Lots of times nobody even had money for food. There was no such thing as AFDC or food stamps then, and we were hungry.

We had only the river water to drink and it was polluted. Our babies kept dying.

Even though they sold our land, we couldn't get at that money to help ourselves. We kept asking the Bureau of Indian Affairs (BIA) to help us help ourselves but they just ignored us. Finally, it got so bad that some kindly people in town noticed. There was publicity, and the BIA hates publicity.

Things got a little better after we got the new houses and the well. We began to hope again. We kept on trying to farm and trying to protect our allotments and our leases. Some of the farmers were cheating us. They'd get the grain buyer to grade the crops off the leases much lower than the crops off the land they owned. That way they didn't have to pay as much rent. It took us a lot of time and work to put a stop to that kind of thing.
But all the time it seemed like we were on a downhill trail. We were losing more and more of our land through people dying and the heirs selling out, and we were losing more and more people through TB and alcohol.

Then World War II came. Our few young men were quick to join up to protect North America - to them it was a part of our Covenant. It's a terrible, lonesome thing for a Kootenai person to have to die thousands of miles from our homeland. But our courageous young Kootenai men were willing to risk it, not just in World War II, but in Korea and Viet Nam as well. The military likes the Kootenais for signalmen. Our language is so difficult no enemy has ever been able to decipher it.

After World War II the Government started that Relocation Program, moving Indians to faraway cities. A few of our people tried it for the sake of the jobs they might get. It didn't work. Most of them came home, where they belong, to our Kootenai Aboriginal Territory.

Once again we tried to farm our allotments ourselves. We had a group called Better Times Club that worked to make things better for ourselves and our children and our unborn. But as usual, the Bureau of Indian Affairs, which was supposed to help us, only made things more difficult. It ended up we had to lease our own land from ourselves to borrow money to buy the machinery we needed. After that we never did break even. It was discouraging.

Things were bad for a very long time. A lot of our children were taken away to government schools and foster homes, and that made things even worse. But as slow and agonizing as it was, we were learning how your system worked, and we kept on trying to make it work for us.

When the government set up the Indian Claims Commission, we Kootenais filed a claim for the loss of our aboriginal territories. We won, sort of: In 1960, the Claims Commission awarded us $\$ 425,000$. Not very much considering what we 
lost, but better than nothing. It didn't all come to us - the cost of the claim came out of it first.

Then they sent in an expert to help us decide how to spend the money. We didn't need him we'd been telling the government for years that we wanted to buy back the allotments we'd lost. We did not want to lose any more land. We kept telling the government expert that.

What we didn't realize at the time was that the local land speculators had powerful allies in Washington, D.C. They didn't intend us to get any of our land back. They intended us to lose all of it. So no matter how often we said we wanted to buy our land back, nobody listened.

After a few years of this, the Bureau of Indian Affairs came and told us what they had decided to do with our money. None of it could be used to buy back our lands. First, we had to reserve $\$ 70,000$ of it to fix up the mission and run the affairs of the tribe.

Then, according to them, each of us would get $\$ 4,700$. Only we couldn't have it, it would be put in special trust accounts for us. Those of us getting any kind of social assistance, it would be paid to the state social assistance. That wasn't legal, but they did it anyway. For those of us under 18, it would be held in trust until we were adults. The rest of us had to have a "good plan" before we could touch ours.

Then they used part of the $\$ 70,000$ to tear down the houses at the Mission. And they made some of us use our $\$ 4,700$ to buy houses in town. It was another kind of relocation, and we hated it. Most of us moved back to the mission, in with our relatives. They kept on tearing down houses anyway, until there were only three left. And when the young ones of us turned 18 and got our "Judgment Money," it wasn't $\$ 4,700$ plus interest, the way they'd said it would be. The most anyone got was $\$ 1,800$.

The Bureau of Indian Affairs explained that by saying they had made bad investments with our money.
It still seems to us our own plan would have worked better. At least we'd have gotten some of our land back.

Instead, winning our land claim didn't make things any better. In lots of ways, it made things worse.

\section{THE WAR}

During the post World War II years the government began providing more services to all North American Indians. There was money for social services and housing and education and employment and better health care. But the Kootenai Tribe of Idaho couldn't seem to get at any of those programs. Even though we never signed the Hellgate Treaty, we had lost everything because of it. Those bureaucrats just kept saying they couldn't help because we didn't have a reservation.

When they built those houses in 1931, they made us sell parts of the allotments to the government to put them on. We thought that was our land even so. Then we found our the government was going to sell part of it.

That was the last straw. We couldn't get a reservation, we couldn't get programs because we didn't have a reservation, and now we were going to lose part of our mission.

On September 20, 1974, in desperation, we declared war on the United States of America. We put up roadblocks on Highway 2 and Highway 95 and charged a ten cent toll to pass through them. We sold war bonds for one dollar to help finance our war.

We didn't know how it would turn out, declaring war, because there were only 67 of us and the government is huge and powerful. But we couldn't see anything else to do - we'd tried every way we could think of.

We made sure everyone understood that we wanted a peaceful war - no guns, no violence. And our people kept to that. The Sheriff of 
Boundary County and the state police made sure the white people kept to it, too.

As soon as the news services heard about the war, we were swamped with reporters from the papers, radio and television. There was a lot of publicity. Many other tribes offered their support. Kootenai People from the six other Kootenai bands came to help.

All that publicity finally got the bureaucrats' attention: Suddenly every government agency wanted to talk to us to see what programs we needed.

It wasn't too long until we were able to declare a "cease fire" in our war. The government agreed to provide us with a good road, sewer and city water. We got 12 new houses through HUD. We got access to education, employment and social development funds. The Bureau of Indian Affairs put our mission into trust for the tribe, so finally the tribe had 12.5 acres belonging to it. We began to plan for the future.

The government wanted us to sign a treaty at that point, but we refused. We knew we needed a better land base than 12.5 acres, and they weren't willing to talk about it. They still aren't.

So officially, a state of war still exists between the Kootenai Tribe of Idaho and the United States of America.

In the middle of all that, we had to go to work to save Kootenai Falls, which is an extremely important sacred place to all Kootenai People. A consortium called Northern Lights wanted to put a dam on the falls. That was about the same to us as tearing down the Vatican to build a shopping mall would be to most Catholics. It was unthinkable.

All seven Kootenai Bands - the entire

Kootenai Nation - came together to save the falls. Environmental groups helped, too. It took a lot of hard work, and a lot of money, but eventually the falls were saved.

The war was the beginning of things starting to get better for us, but we still had a long way to go.

\section{THE STORM PASSES}

Experts say that when people survive brief natural disaster like an earthquake or tornado, it takes them months or even years to get over it.

The Kootenai Tribe of Idaho has survived an unnatural disaster that lasted almost one hundred years. We know we aren't going to get over it in one year, or even one generation.

During the worst of it, nearly every adult member of our community was addicted to alcohol. We turned our grief and despair inward upon ourselves, our families, even our children. The U.S. cavalry, the early settlers and the Blackrobes had taught us that violence was an acceptable form of behavior, and we turned that on ourselves, too. Violence became the norm in our community for a little while. The scars of the violence we suffered and the violence we inflicted will be with us for a long time. But gradually, we are healing.

As soon as we had secured the objectives of our war, we turned our minds to plans for the future. We had proven to the government and the American public our legal and moral right to continue to live in our aboriginal homelands as a vital part of the Kootenai Nation. We had finally obtained - at least on paper - the services and programs to which we were legally entitled. We had proven to ourselves that we were not completely powerless. Now we could begin to work for the future, for the unborn.

In 1947, under pressure from BIA, we had abandoned our traditional form of government and adopted your "democratic" system of elected leadership. Before that, we had an hereditary chief, and his word was final. But a wise chief always made sure there was a consensus of the people before deciding anything, so that everyone was of one heart and one mind.

After 1947 we had democracy and we always had a dissatisfied minority. It was divisive, it weakened us. 


\section{The Kootenai Tribe of Idaho Fisheries Program}

Fisheries resources on the Kootenai River were historically abundant and were utilized by the tribe for cultural and subsistence purposes. Over the past few decades, native fish stocks have declined significantly in the drainage due to changes in the natural ecosystem. Some of these changes include alteration in river flows and lower productivity due to the operation of Libby Dam, diking and diversions resulting in loss of side-channel habitat, and poor water quality from past industrial, agricultural and mining influences.

In 1989, the Kootenai Tribe of Idaho became involved in the study of the decline of the Kootenai River white sturgeon and contracted with the Bonneville Power Administration (BPA) to build and operate an experimental white sturgeon aquaculture facility. The Kootenai River white sturgeon, a unique stock that has been separated from other Columbia River white sturgeon stock since the last glacial age, was listed as endangered in 1994 under the authority of the Endangered Species Act of 1973. The tribe, along with other state and federal agencies, has been integrally involved in the recovery effort as a co-manager of the Kootenai River system. Efforts to recover the Kootenai River white sturgeon include the use of conservation aquaculture to preserve the existing genetic diversity, as well as attempting to re-establish natural recruitment by restoring suitable ecosystem functions that have contributed to the decline.

The effort to conserve natural resources does not end with the Kootenai River white sturgeon. The tribe recognizes the connection of all resources in the web of life, and that the preservation of the tribe depends on protecting these resources in a holistic manner. Another project undertaken by the tribe involves identification of factors that may be limiting to native resident fish species (white sturgeon, kokanee, bull trout, westslope cutthroat, interior redband trout and burbot) using an ecosystem approach. Because the entire ecosystem has been altered for decades, so much has already been lost. But the tribe looks to the future with the hope that the native fish may once again inhabit their river in abundance.

So after the war we went back to having an hereditary chief again. He is Chief Raymond Abraham, a direct descendant of the Chief Abraham who started the ferry at Bonners Ferry. Under our Chief's leadership we do our best to achieve consensus before we make any major decisions, and we usually succeed.

The Indian Self Determination Act of 1976 gave the tribes the power to contract the programs BIA had always administered. We began to contract our programs, starting with our community health worker. We hired a planner to help us organize our plans for the future. We hired an economic development worker to establish an economic base not dependent solely on government funds. Soon we were managing our own administration, real estate, natural resources, rights protection, law and order, and judicial systems.

On December 1, 1986, the first major step in our economic development program came into being: the Kootenai River Inn.

The Inn is a Best Western Hotel, whollyowned by the Kootenai Tribe of Idaho. It provides fifty jobs in Boundary County, as well as significant revenues to local business. We are very proud of it.

Basing our negotiations on the principle of Aboriginal Rights, we next succeeded in securing an agreement with Northwest Power Planning Council and various other entities to revive the almost extinct white sturgeon population in the Kootenai River. In 1987, we signed a contract for the construction, operation and management of a 
sturgeon hatchery. This project, too, will bring significant economic benefits to Boundary County.

During all those terrible years, we never lost sight of our original purpose, our Covenant: to be guardians of the land forever. We continue to work to that purpose.

\section{THE PREsent AND the Future}

Now it is almost the year 2000 - over one hundred years since the first settlers began forcing us off our lands along the river. Along with the State of Idaho, we celebrate our own centennial - a century of survival in the face of incredible odds.

For much of that century, every institution of American society has been brought to bear on us, to make us abandon our homelands and go away. The government, the military, the legal system, the schools, the health care system and even the church have all, at one time or another, been used in the effort to make the Kootenai Tribe of Idaho disappear. And all have failed. We celebrate a victory - we are still here, strong and growing. We have kept our Covenant with our Creator.

In the 20-plus years since the war, we have developed our plans, set our goals. We have a short-term twenty-year comprehensive plan, which addresses most aspects of our community life. It is intended to heal the wounds of the past as swiftly as possible, and prepare us to meet the future. We have a long-term plan that protects and enhances the lives of our generations unborn.

Under our short-term plan the tribe will contract and manage all its own programs. At present, we employ twenty people. Our tribal payroll injects more than half a million dollars per year into the local economy. We expect those figures to double.

The tribal elders of the Kootenai Nation are helping us to conserve our past. They teach us the skills and traditions of our ancestors. We have learned to build our Kootenai canoe, our Tule Tipi, our fish trap; to gather and process our traditional foods correctly. Many of us speak our

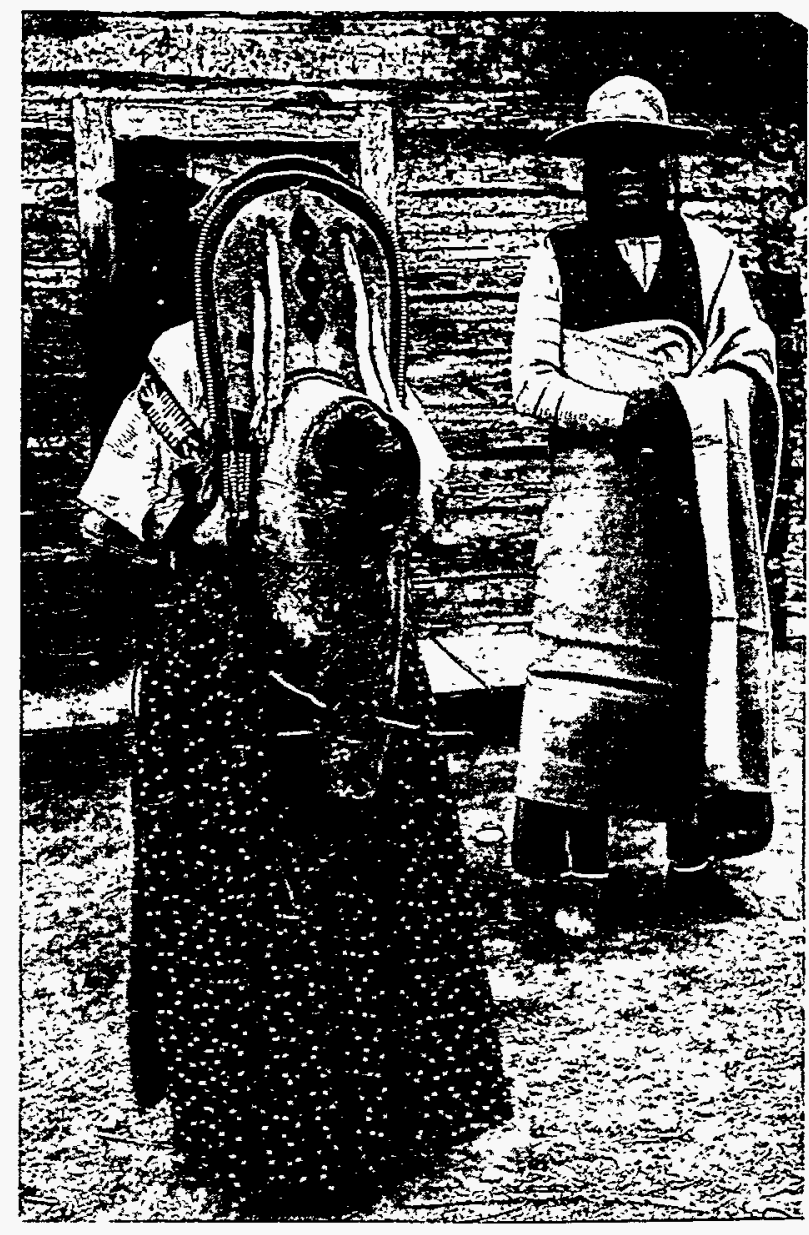

Kutenai Indians probably c. 1900. The woman utilizes a baby carrier typical of the Plateau region, the rounded top embellished with beadwork in combined geometric and floral patterns.

language. We can still use our international sign language. We are recording our oral history and the songs and parables of long ago, to teach our children as our ancestors taught theirs.

Federal law, in the forms of the Freedom of Indian Religion Act, and the National Historic Sites Preservation Act, protects the historic and sacred places of all American Indians. The U.S. Supreme Court has ruled that all tribes have rights within their Aboriginal Territories, even outside reservation boundaries.

We know that within our aboriginal territory, there is no bit of land - no shoreline, no creek, no hillside, no forest, no prairie, no alpine meadow nor rocky peak nor snowfield - that has not felt 
the touch of Kootenai feet. There is no smallest place that lacks historical or religious importance, no place that does not bear its ancient Kootenai story and name. We continue our guardianship. Using the best of the technology of today, we record the treasures of the past on computer. When industrial development or resource extraction is planned, we refer to our computerized land use inventory to ensure the safety of Kootenai aboriginal rights.

We look for ways to improve honest communication and mutual respect between ourselves and the larger community of Boundary County. As this is being written, most of us are busy preparing for our annual JOM day tomorrow. During JOM day, all the teachers and children of the Bonners Ferry elementary schools visit our community to take part in a mini pow wow, share some of our traditional activities and enjoy a taste of our traditional foods. And everyone has a wonderful time.

We participate in the Chamber of Commerce and local service organizations. We enjoy an excellent working relationship with the National Forest Service and other state and federal agencies. We do not believe that the best interests of the Kootenai Tribe of Idaho and those of town, county and state are mutually exclusive; we believe that all our interests are best served through cooperation and negotiation between equals.

As we celebrate a century of survival, we look to the future. We watch our beautiful children playing, and we think: That one is our future doctor, that one our future teacher, that one our future forester - we see each one's gifts and talents and where each will fit in the future of the tribe, and our hearts are filled with joy.

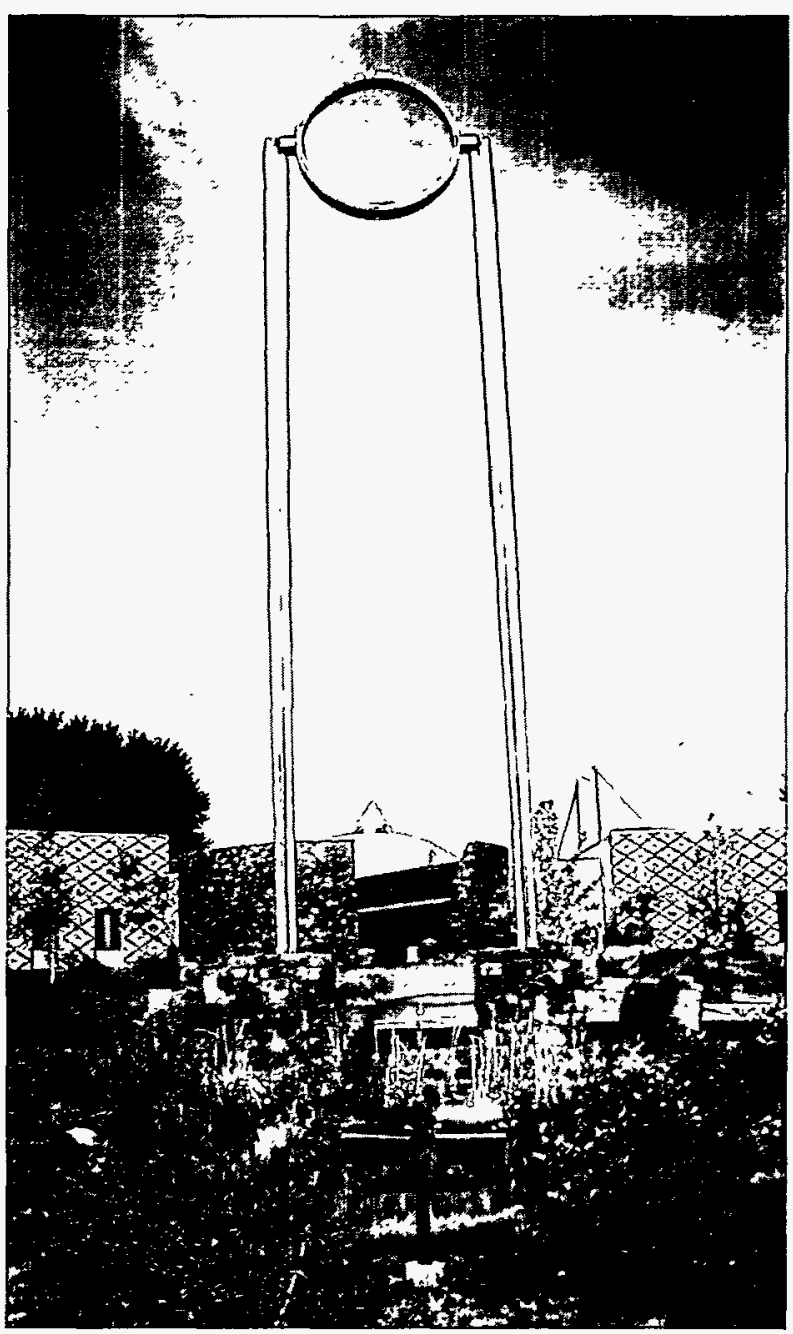

Home of the Kootenai 


\section{Nez Perce Tribal PROFILE}

\section{LOCATION AND LAND BASE}

The Nez Perce Indian Reservation was established by treaty in 1855 is located in central Idaho. The reservation is geographically dominated by the Camas Prairie, which is deeply dissected by forested canyons that form the tributaries of the Clearwater, Salmon and Snake Rivers, bordering the prairie on the north, south, and west respectively.

TRIBAL ENROLLMENT

\section{NATIVE LANGUAGE(S)}

dialects of the Sahaptin Family

\section{TRIBAL GOVERNMENT}

The Nez Perce Tribal Executive Committee, the authorized representatives of the Nez Perce Tribe, have assumed a vital role similar to state governments.

\section{ECONOMIC BASE}

The Nez Perce Forest Products Enterprise aggressively merchandises and promotes forest products which meet local, regional and international marketing demands. It also provides further services that include presale layout, timber inventories and appraisals, reforestation and site preparation. The enterprise is solely owned and operated by the Nez Perce Tribe.

Tillable lands used for farming of small grains and lentils offer good revenue on a yearly basis. Leasing of farmlands has proven to be a good revenue generating program.

Currently, the tribe operates a tribal store, a limestone enterprise, and the Nez Perce Forest Products Enterprise, an entity that is composed of other businesses directed towards the wood products industry.

Formulating the future direction that tribal economic development will undertake has resulted in the evaluation of many opportunities that exist in the business sector. Projects are screened in light of criteria such as: return on investment, market

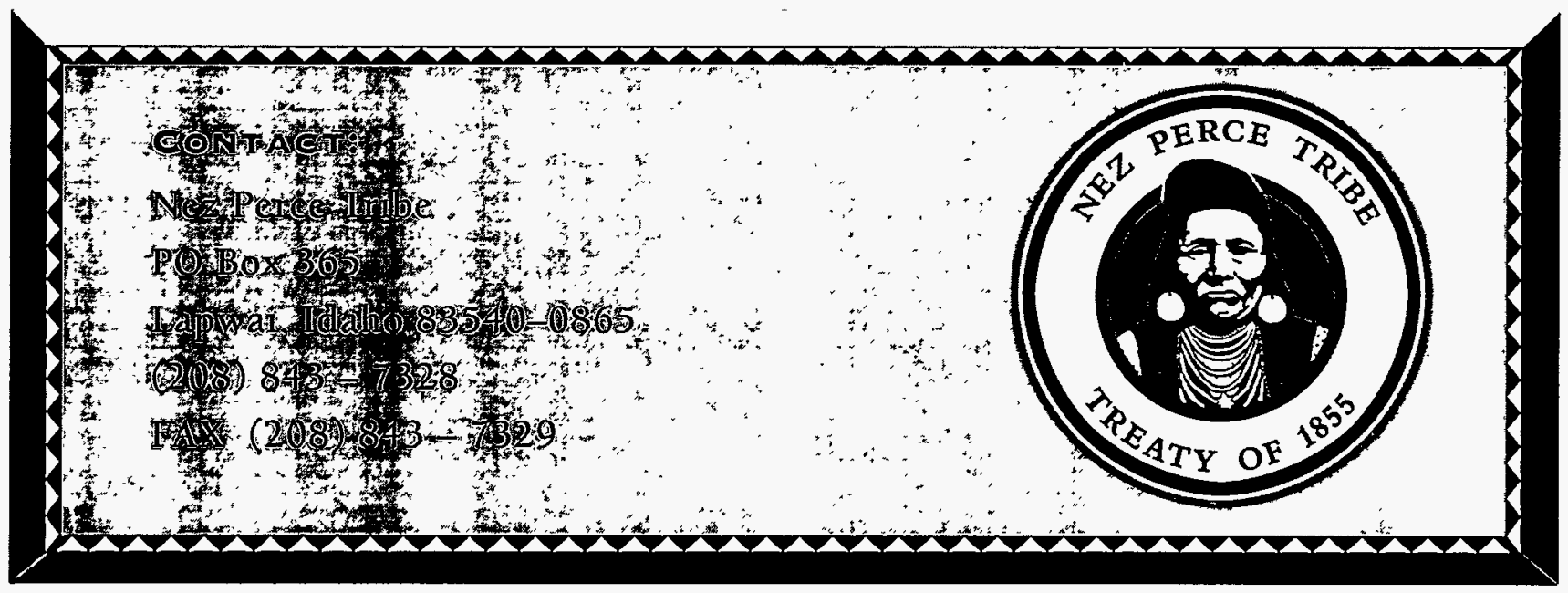


and revenue potential, tribal member employment opportunities, and the promotion of tribal and community relations. Some projects currently under review include: the building of a new tribal convenience-grocery store, the implementation of a recreational vehicle campground, the erection of a gaming enterprise that will feature bingo and pulltabs, the marketing of tribally grown grains to markets of both national and international origin, and the construction of a Nez Perce arts and crafts enterprise that will promote crafts made by tribal members. 


\section{THE NIMIIPU (NEZ PERCE)}

THE EARTH WAS THE MOTHER OF ALL LIFE AND THE MOTHER OF THE PEOPLE. THE Nez Perce Values the Earth NOT FOR WHAT IT REPRESENTS IN GOODS OR MONEY, BUT FOR ITS BEING THE SOURCE OF HIS LIFE AND PROVIDING ALL HIS NeEdS.

We, the Nimiipu people, believe in our own creation story that has been told from our ancestors in the early times until today. Our story tells of a new world before there were any men. A huge Monster lived in the Kamiah area, which is located in the Clearwater Valley. The Monster swallowed all of the animals for miles around and this angered Coyote. Coyote then decided that he would kill the Monster. Coyote allowed himself to be swallowed by the Monster. Coyote cut up the heart of the Monster, and with five agate knives he cut the Monster's body into small pieces. From the small pieces came the many different tribes; these tribes had their own strengths and identities along with a place where they could live. But Coyote had forgotten about the land where he was standing and his friend the Fox reminded him that the beautiful Kamiah valley was without people. Coyote did not despair; from a few drops of the

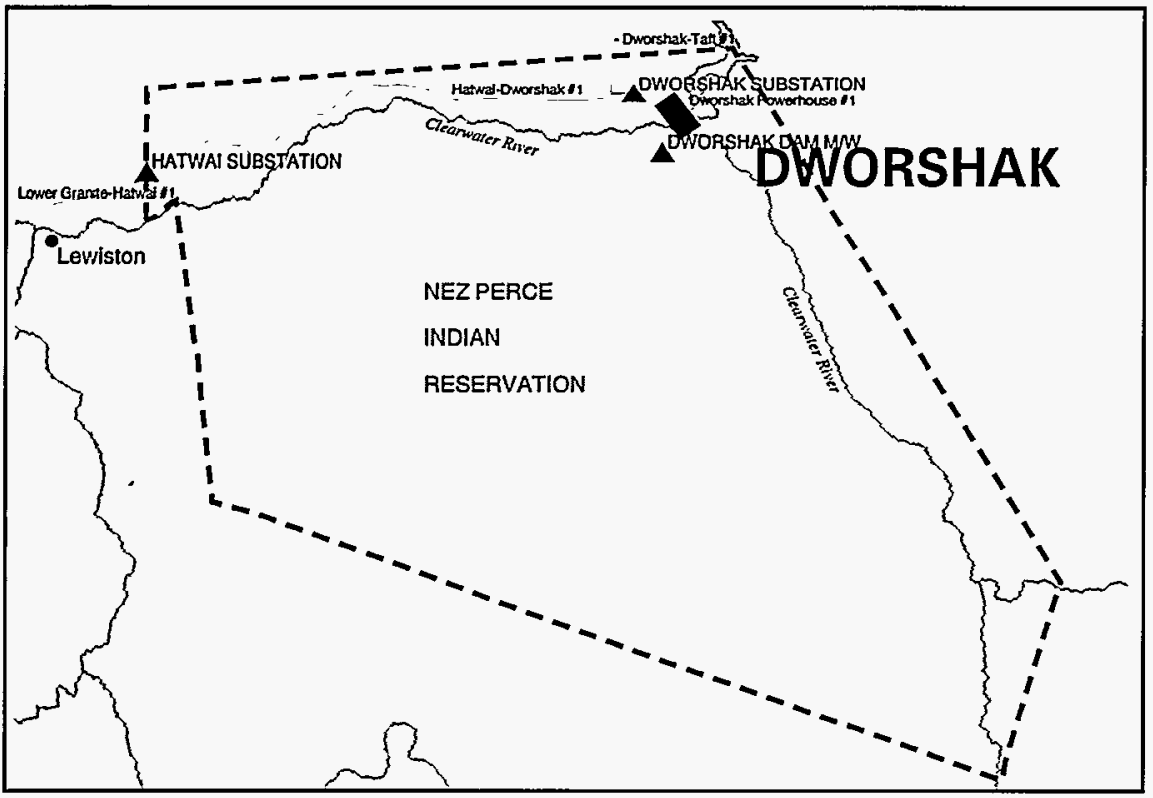

forms of communication,

storytelling, or a recording of events of the early Indian people who lived here.

Many years ago before the contact with the white man, the Nez Perce traveled great distances overland for buffalo hunting to the eastern plains toward what is now Montana. The Nez Perce searched for food in the vast territories known as Oregon, Washington and a great area in Idaho. The early groups or bands of the Nez Perce were dependent on the environment 
and the areas where they lived. The big game the Nez Perce hunted included the deer, elk, moose, bear and mountain sheep, which were usually found in the higher elevations. Large land areas were needed to support a family in their food gathering activities, which made it necessary to move with the growing seasons of certain roots, berries and herbs. A favorite and major food source for the Nez Perce was a bulb known as "camas," which was harvested in the upper elevations in the surrounding prairies. This food is still harvested today, and remains a favorite.

When Indian people moved from area to area, they traveled with their families and carried all their household goods with them. Before the horse was introduced to the Indian people, the moving was done primarily with the use of dogs and family members. However, with the introduction of the horse in Indian territory, the horse became an important factor in the lives of the Indian people. Moving from food gathering areas to hunting areas was usually a major family event that required the cooperation of all family members.

In the winter, the Nez Perce lived in teepees made from the hide of the buffalo and tule mats. The foundations of these winter quarters were usually dug two feet deep below the level of the ground to keep the heat in the teepee and the wind out. Indian families were usually large. Extended family groups consisted of all children, parents, aunts, uncles and the elderly members such as grandparents. Due to the size of the Indian families during the winter months, they lived in a "long house," which was usually over a hundred and fifty feet in length. These long houses helped conserve wood and offered protection for the family. During the winter months, women cooked, sewed and did their weaving of baskets or bags for their own use or to be used later for trading. The male members of a family usually made ropes from horsehair, or made nets for fishing, arrows for hunting, or trapped along the streams for furs for use by the family. The elders of the Indian family held a place of prominence for they were the teachers, advisors, recorders of important events, instructors in living and caretakers of the young. They were also the family members who were responsible for carrying on and teaching the $\mathrm{Nez}$ Perce traditions from generation to generation.

It was not until President Thomas Jefferson obtained a grant from Congress in 1803 for the exploration of the northwest region to the Pacific coast that a large scale expedition through the Louisiana Territory became a reality. In 1804 , Meriwether Lewis and William Clark led an expedition from St. Louis, Missouri to the Pacific coast that explored the Louisiana Territory. The explorers traveled by boat, on horseback and on foot until they reached the Bitterroot Mountains, where they encountered perilous conditions. It was after this crossing of the Lolo Pass that Lewis and Clark first met the Nez Perce people in September of 1805. The Nez Perce befriended them when they arrived in Nez Perce country in a starved and ragged condition. The explorers were greeted with warm hospitality, willing assistance and cooperation from the Nez Perce that enabled the expedition to continue to the Pacific coast.

This historical event opened the Northwest Territory for trading companies and their mountain men, who soon converged on the virgin wilderness that was home for the $\mathrm{Nez}$ Perce and other tribes. This vast wilderness contained ample furbearing animals, such as mink, otter, fox and the coveted beaver.

The furs from these animals were in great demand on the eastern shores of the United States, as well as in England, France and Spain. As fur traders

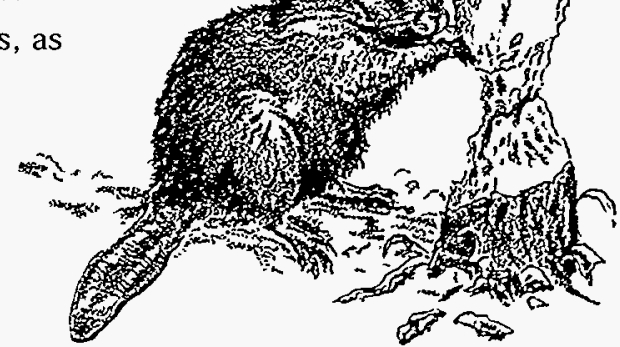


and trappers penetrated the Rocky Mountains and explored the far west, others searched for precious metals, especially gold. Others wanted land to farm or raise cattle on. The Nez Perce did not usually trap furs for the fur companies, but did trap for their own use.

Many times fur trading companies became a threat to the established way of life for the Indian people by depleting many of the furbearing animals that provided food or clothing for them. The arrival of settlers and cattlemen in Indian country also proved to be detrimental, when they fenced prime grazing lands and natural springs, and allowed cattle or sheep to destroy native food sites. The westward movement began with the surge of people demanding land that was considered free in the new territory, giving little thought to the Indian people who had occupied the land from the earlier times. This demand by the settlers and others for free access to land, even land occupied by the Indians, gave cause for the first appointed governor of Washington territory, Isaac Ingalls Stevens, to make plans for meeting with the Indians in their home base areas. Governor Stevens' prime concern was to keep the Indians from uprising and impeding the westward movement of the settlers. Another consideration that made the meeting with the Indians imperative was the fact that, in 1853, four northern army expeditions had been outfitted for the purpose of determining possible route for a railroad to the Pacific coast. The governor realized that the steady influx of settlers, miners and others would only increase and eventually cause conflict with the Indians whose lands were being slowly eroded. Stevens' role as Superintendent of Indian Affairs offered him an opportunity to negotiate with the tribes, and segregate the Indian people by force if necessary to reserves of land, either within the Indian home base or within another area.

A great council was held in the Walla Walla valley during the month of May in 1855 for the purpose of inducing the Indian tribes, which

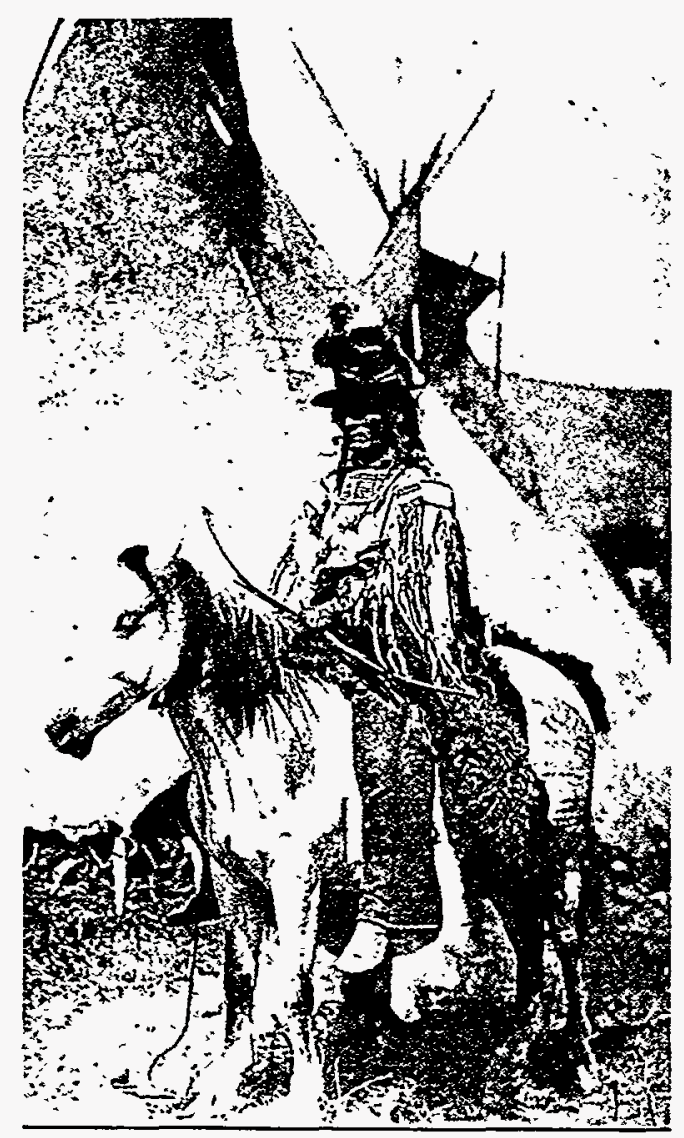

Looking Glass, a Nez Perce chief, shown in a Crow camp, 1871. Looking Glass and his group of Nez Perce were firm friends of the Mountain Crow. He was killed at the Bear Paw Mountains in 1877.

included the Nez Perce, Cayuse, Walla Wallas, Umatillas and the Yakamas. Each tribe wished to keep a portion of their own home land as part of its reserved land or reservation. Governor Stevens was forced to keep peace with the tribes by agreeing to their request, which allowed the Nez Perce people to remain in their own territory.

In an effort to obtain a mutual understanding and peace for the settlers and others who were rapidly populating the northwest, Governor Stevens proposed a large reservation for the $\mathrm{Nez}$ Perce people in return for yielding their right to land they had occupied for generations. But the $\mathrm{Nez}$ Perce did not give up their right to fish and hunt on land that was relinquished in the treaty of 1855 , or in any later treaty. They also reserved the 
right to fish outside the reservation and use public lands for grazing their horses and cattle outside the reservation. As part of the treaty agreements, the government agreed to build, furnish, and operate two schools, two blacksmith shops, two mills, one tin shop and one hospital. The Nez Perce were promised $\$ 200,000$ for a period of twenty years for improvements on the reservation and the purchasing of merchandise for distribution to tribal members. The following years proved to be filled with delays, frustrations and anger for the Nez Perce people, who waited for the treaty stipulations to be enforced. For many of the tribal people the reality of the treaty stipulations were never to be realized; for others the promises were again just broken promises.

Again a change was on the horizon, for gold was discovered on the reservation at a location that was to be known as Pierce. Again there followed an invasion of gold miners on the reservation, which was contrary to the stipulations of the 1855 treaty. The growing conflict between the Nez Perce and the settlers, land developers and now the gold miners became an issue that caused a demand for a new treaty that would change the boundaries and release more land for the settlers and the many others who were finding their way into the land of the $\mathrm{Nez}$ Perce. A council was assembled in May 1863 and was held at Fort Lapwai where three hundred soldiers came to prevent conflict at the council. The second treaty of 1863 greatly reduced the original reserved land base of the Nez Perce people to a fraction of its former size, forcing a majority of the many bands that made up the Nez Perce people to give up their land, which was prime land that had been their home. The new treaty brought new dissension among the Nez Perce because of the changes in the size of the boundaries, but also because of the non-payment for improvements on the reservation for the 1855 treaty, and because of the agreement that all settlers were to be kept off the reservation, which had not happened.

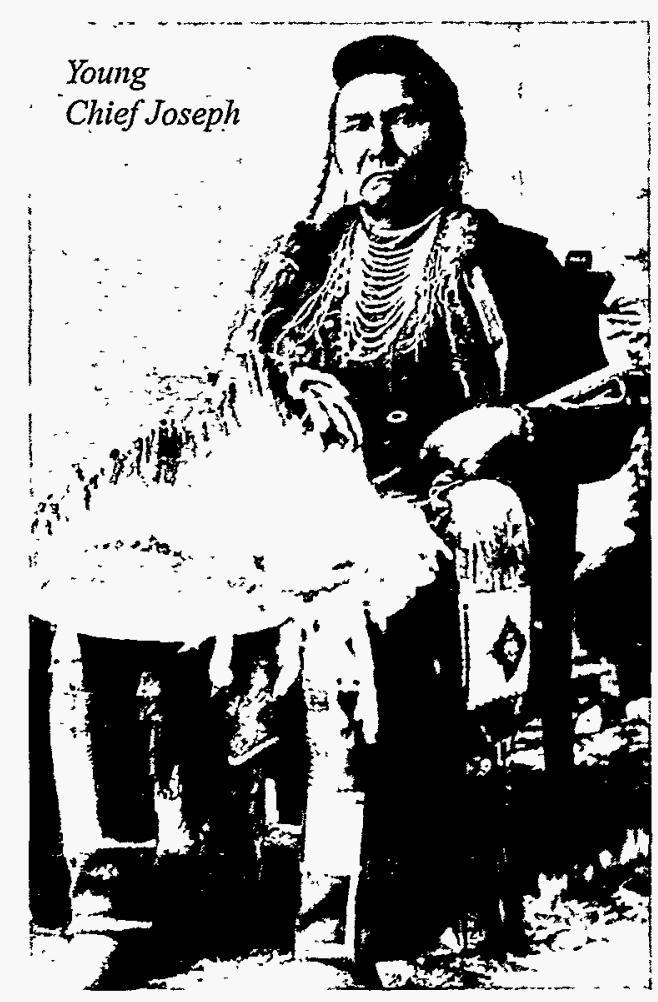

Dissatisfaction and resentment of the new stipulations brought on vigorous resistance by the bands that lived in the Wallowa country, the people of Chief Joseph. During the years of 1870 and 1877 , the cattlemen and settlers moved into the Wallowa territory, built homes, put up fences around springs and prime range land. No white encroachment was more bitterly resented than this blatant land takeover from the Chief Joseph band. The Wallowa Territory had been the homeland for the Joseph people for generations, for it was a valley with beautiful lakes and streams that were abundant with salmon, and forests with enough game to fill the needs of the families who occupied the land. It was the 1863 treaty that would change these circumstances by taking over the land of the Joseph people without their consent. The resistance of the non-treaty bands who were being forced to leave their lands to a greatly reduced reservation - resulted in the famous Nez Perce War between Chief Joseph and Colonel O. Howard. The war resulted in the Chief Joseph people being sent into the Oklahoma 
territory where many died and others waited to be returned to the northwest. This marked the end of an era that forever restricted buffalo hunting expeditions to the east, traditional migratory movements for hunting, fishing and trapping throughout the territory, bringing an end to their tribal independence.

All western tribes soon suffered the same fate as the Indians of the east, for the northwest Indians who had been forced to accept reservation life became more and more dependent on the government for survival. Congress had passed laws that increased federal control over the Indian people with one of the main objectives being the assimilation of the Indian into white mainstream. Educating the Indian became a major goal, and by 1887 over two hundred Indian schools had been established. This major thrust for education was by force in many instances, for Indian families had to send their children to school. Usually these schools were located in different states and alien surroundings, and lasted for long periods of time with the hope that this would mark the end for Indian language and customs for those who would accept education and return to the reservation to teach others. Although Indians throughout the United States had become the subject of government pressure for great changes, acculturation and inducement to leave their homelands, the $\mathrm{Nez}$ Perce people were determined to retain their culture, language and many of the traditions of the tribe.

In 1887, the General Allotment Act, or the "Dawes Act," was passed by Congress in an effort to accelerate the assimilation process of the Indian people. This act allowed the government to divide communally held tribal lands into individual parcels that would require each individual tribal member an allotted number of acres to be held in trust in his or her name for a period of twenty-five years. The land that was not "allotted" to a tribal member was considered surplus and sold to white settlers for farms and cattle ranches. This policy was detrimental to the economy of those tribes that were never given the opportunity of making their objections concerning future land use. The Dawes Act created many scattered Indian land holdings, but none large enough to build a sound land base. Due to the Dawes Act, many reservations were soon overrun with white people and by 1934 , only 50 million acres belonged to the Indian tribes across the nation.

In 1924, citizenship was granted to the Indian people including the Nez Perce. However, this citizenship offered no solution to their extreme poverty, nor did it open job opportunities on the reservations.

On June 18, 1934, Congress passed another bill called the "Indian Reorganization Act," or the "Wheeler-Howard Act," with the express purpose of rehabilitating the Indian tribes' economic situation and helping them realize their own potential and initiative, which had almost been destroyed during a century of oppression, conflict and government interference. This bill also put an end to further allotment of Indian tribal lands to individual Indians, and also allowed the Secretary of the Interior the authority to create new reservations for landless tribes and to restore lands not sold to non-Indians to tribal ownership. Tribes were also encouraged to adopt their own governments and to conduct business for their reservations and people. These changes in policy during different administrations proved to be inadequate for any long range economic planning for the reservation.

The Nez Perce Tribal Executive Committee, the authorized representatives of the Nez Perce Tribe, have assumed a vital role similar to state governments. This executive committee, from its inception in the 1930 s, has inherited many diverse problems that impede the progress of tribes and their people. The complex relationship between the tribes and the United States under the treaties - assuming the role of sovereign nations as well as the role of citizens and voting members of the 
state in which they reside - has proven to be a learning experience for all those concerned. For the Indian people as with all citizens of this country, the responsibilities of government are not taken lightly, nor are the Indians allowed the opportunities to be complacent about any laws that affect them.

\section{FOREST MANAGEMENT}

The Nez Perce people then and today are of one mind with the earth. The necessity of becoming "one" with the earth and our environment is characterized by natural resource management that will meet the demands of modern society while providing cultural protection and economic stimulus.

The Nez Perce Indian Reservation geographically is dominated by the Camas Prairie, which is deeply dissected by forested canyons that form the tributaries of the Clearwater, Salmon and Snake Rivers, bordering the prairie on the north, south and west respectively. Much of the prairie supports annual crops of wheat, rapeseed, and barley; these crops are mixed with forests of douglas fir and ponderosa pine. This forms a rich mosaic of habitat which is home to diverse and abundant populations of wildlife.

The Nez Perce Forest Program is charged with the responsibility of managing timber resources in accordance with the best management practices for sustained harvest yield. This effort calls for a proper balance of interdisciplinary skills within the tribal structure that meets a desired condition to achieve a common benefit for the tribe and its members.

The Nez Perce Forest Program currently manages 47,640 acres of forest lands utilizing integrated resource management goals throughout the following areas of responsibility: silviculture, forest pre-sale, timber sales, permit administration, reforestation development, management planning and inventories, fire management, and forest pest management.
The Nez Perce Tribe has also charged the Forest Program with the responsibility of coordinating fish and wildlife habitat management with forestry resource management activities for protection of both quality and quantity. The program is involved in every phase of wildlife management on the reservation and several co-management projects within the 13 million acre area ceded to the United States Government by treaty. It is by treaty that the Nez Perce Tribe has retained the authority to hunt on public lands and thus manage the wildlife populations that exist there, in cooperation with other states and federal agencies.

The Nez Perce Forest Products Enterprise is an entity chartered by the Nez Perce to do business on behalf of the tribe both on and off the Nez Perce reservation. The purpose and objectives are the following: to develop management systems, promoting stable business growth of forest products on the Nez Perce Reservation and to promote the best and most efficient methods utilizing reservation resources on a sustained yield basis.

The Nez Perce Forest Products Enterprise aggressively merchandises and promotes forest products that meet local, regional and international marketing demands. It also provides further services that include presale layout, timber inventories and appraisals, reforestation and site preparation. Timber harvest scheduling and logging activities are analyzed and evaluated in order to complete contract requirements in the most cost effective and timely manner to meet fluctuating market demands. The enterprise is solely owned and operated by the Nez Perce Tribe and dedicated to providing the Nez Perce Tribe with the highest financial returns while maintaining the ecological and biological integrity of tribal lands.

Meanwhile, the tribe seeks to diversity its resources and investments that may offer a profitable future in building their economic- and landbase. Tillable lands used for farming of small grains and lentils offer good revenue on a yearly 
basis. Leasing of farmlands has proven to be a good revenue generating program.

\section{WILDLIFE MANAGEMENT}

Archaeological records show the Nez Perce People's reliance on wildlife resources in this region for the last 10,000 years. Wildlife resources were used in every aspect of $\mathrm{Nez}$ Perce lifestyle. Various sources document the Nez Perce using fire, whether intentionally or not, to manage habitat to produce forage for their large numbers of horses, and the wildlife on which they depended. With the introduction of European civilization and implementation of modern methods of fire control, many people feel the frequency an area is burned has gone down but intensity has increased. Perhaps there was more wisdom in the "old ways" than was recognized at first. Today, the Nez Perce Tribe has reintroduced the use of fire as a tool to manage wildlife habitat on their own land while implementing additional state of the art management techniques.

The tribe's wildlife program was initiated in 1983. As the programs builds, personnel are focusing on the framework for wildlife management on the reservation. Included are evaluations of habitat availability, development of wildlife management plans, habitat enhancement and trend surveys for species of special concern, and development of a wildlife program to mitigate for lost habitat due to hydroelectric power generation.

\section{Cultural Resource MANAgement}

The Cultural Resource Program is designed to voice tribal concerns for the better management of cultural resources through active preservation, conservation, protection and the enhancement of cultural resources. The Nez Perce Tribe recognizes that a spiritual respect of the earth and it resources is a tradition that has been passed down for generations. We carry on that tradition by insuring our lands and cultural resources are maintained in their natural state as much as possible. A diverse range of cultural resources exists on the Nez Perce Reservation, and within our ceded areas including prehistoric $\mathrm{Nez}$ Perce resource procurement sites, hunting and gathering encampments, fishing stations, villages, open camp sites, battlefields, petroglyph and pictograph sites, historic mining sites, prehistoric trails and traveling routes.

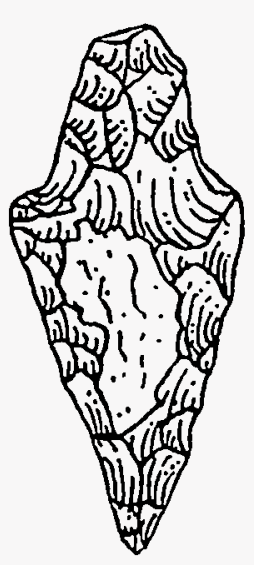

It is realized that some of these resources will be lost through erosion and human contact. However, the Cultural Resource Program works to keep this to a minimum through implementation of its own policies and procedures as well as insuring that persons coming into contact with cultural resources comply with all applicable laws that regulate this area. Technical reports addressing archaeological concerns and development of cultural resource management plans for the area are a few of the examples which the program has advanced. Such reports note that the location and volume of water resources have affected the distribution of plants, wildlife and economic pursuits of the Nez Perce prehistoric and historic populations for at least 10,000 years. The program also maintains a co-operative agreement with the neighboring Forest Service offices to insure cultural resources remain available for future generations. As partners, with the Clearwater National forest and Nez Perce Forest. we have worked to provide an accurate interpretation of the history of the Nez Perce.

Our dream is to create an interest in cultural resource management to attract young people into the profession. At present, all cultural surveying, archaeological testing and monitoring, is conducted by tribal members through the program. As an advocate for cultural resource protection, we have completed a traveling display and literature that is available throughout the northwest. 
We are also active in educating the public through offering lectures and slide presentations to various groups, public schools and universities.

We strive to tell the history of the Nez Perce precisely for our children and future generations in order that they may have accurate knowledge of how Nez Perce lived.

Cultural resources are disappearing at an alarming rate. Large numbers of sites are being destroyed or illegally removed by willful scavengers who take them for personal profit, or casual collectors who don't understand that such artifacts should be left undisturbed.

These "pothunters" are by far the most serious offenders as they locate and plunder choice sites. Human burial sites, sacred to the Nez Perce, are particularly sought because of the ease in confiscation.

These illegal behaviors exist despite federal laws to protect these fragile nonrenewable resources. Public cooperation is needed to report thefts. It is recommended that the public refuse to buy goods stolen from the tribe. Help us to protect the American heritage, report any disturbances to the Nez Perce Tribe, the local Forest Service, local police or the Idaho Historic Preservation Office. 


\section{SALISH/KOOTENAI TRIBAL PROFILE}

\section{LOCATION AND LAND BASE}

The Flathead Reservation was created under the Hellgate Treaty of 1855 , and is one of seven reservations in Montana. North of I-90 between Missoula and Kalispell, fertile valleys and towering mountain peaks of northwestern Montana are the motifs of the Flathead Reservation. The reservation comprises over 1.245 million acres. Following losses due to the Allotment Act (1908) and the Homestead Act (1910), 771,900 acres remain Tribally-owned.

\section{THE PEOPLE}

The Flathead Indian Reservation is home to the Confederated Salish and Kootenai Tribes. The tribes are a combination of the Salish, the Pend d'Oreilles and Kootenai peoples. Of the 6,829 enrolled tribal members, about 4,076 live on or near the reservation.

\section{Native Languages}

The Salish, Pend d' Oreille and Kalispel peoples speak dialects of the Salish family of languages. The Kootenai people speak the Kootenai language, which is an isolate language, not related to any larger language family.

\section{ECONOMY}

Montana Power Company pays the Confederated Salish and Kootenai Tribes $\$ 9.4$ million annually to lease land on which the Kerr Dam is situated, near Polson. Potential for development of additional hydroelectric power sites and recreation areas also derives from logging and Christmas tree sales. 850 people are employed by the tribe.

\section{TRIBAL GOVERNMENT}

Since the Indian Reorganization Act (WheelerHoward Act, 1934), the Confederated Salish and Kootenai Tribes have operated as and Indian-owned corporation, governed by a tribal council under the executive of a tribal chairman, elected within the council. The ten tribal council members are elected from eight reservation districts.

\section{DEPARTMENTS}

Education, Natural Resources, Head Start, Law and Order, Tribal Court, Tribal Health and Human Services, Tribal Forestry, Kicking Horse Job Corps Center, Housing and Community Development, Mission Valley Power, Salish Culture Committee, Kootenai Culture Committee, People's Center, Two Eagle River School, Salish Kootenai College.

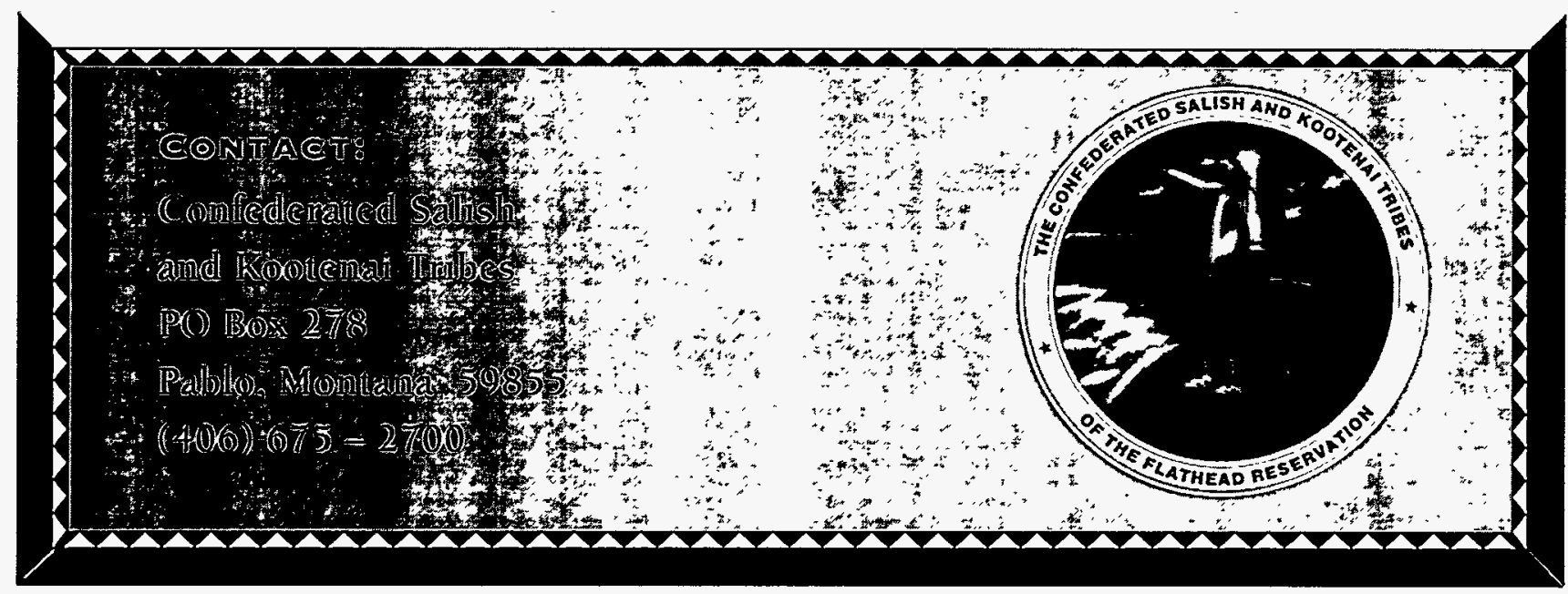




\section{SALISH/KOOTENAI}

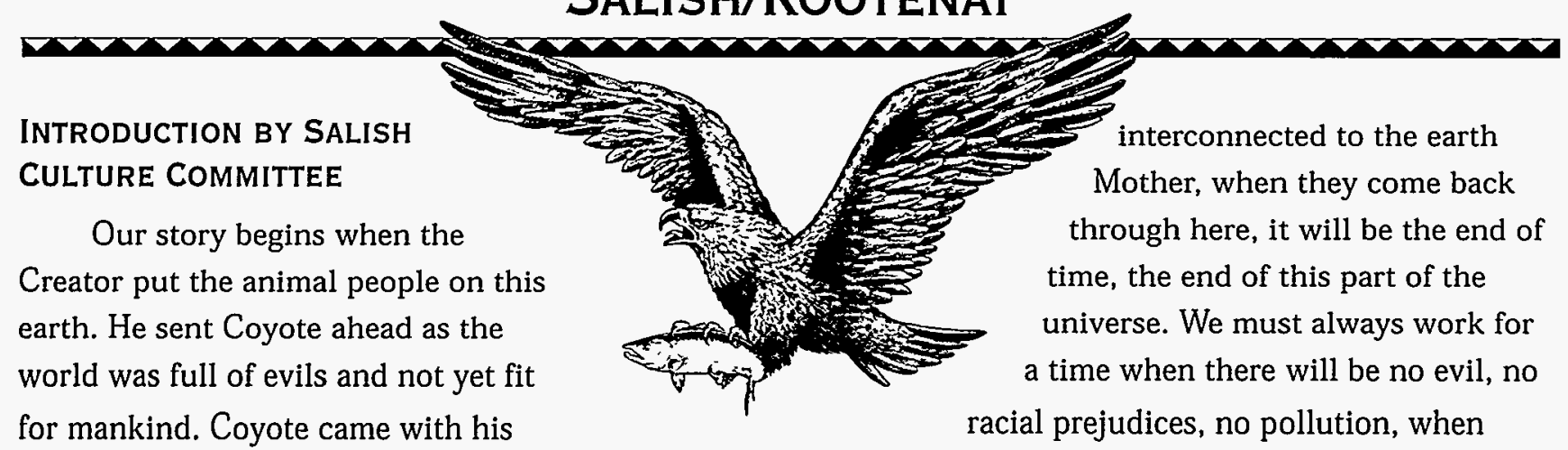

brother, Fox, to this big island, as the elders call this land, to free it of these evils. They were responsible for creating many geographical formations and providing good and special skills and knowledge for man to use. Coyote, however, left many faults such as greed, jealousy, hunger, envy, anger and many other imperfections that we know of today.

The elders tell us that Coyote and his brother are at the edge of this island waiting. If we do not live and respect each other as one who is

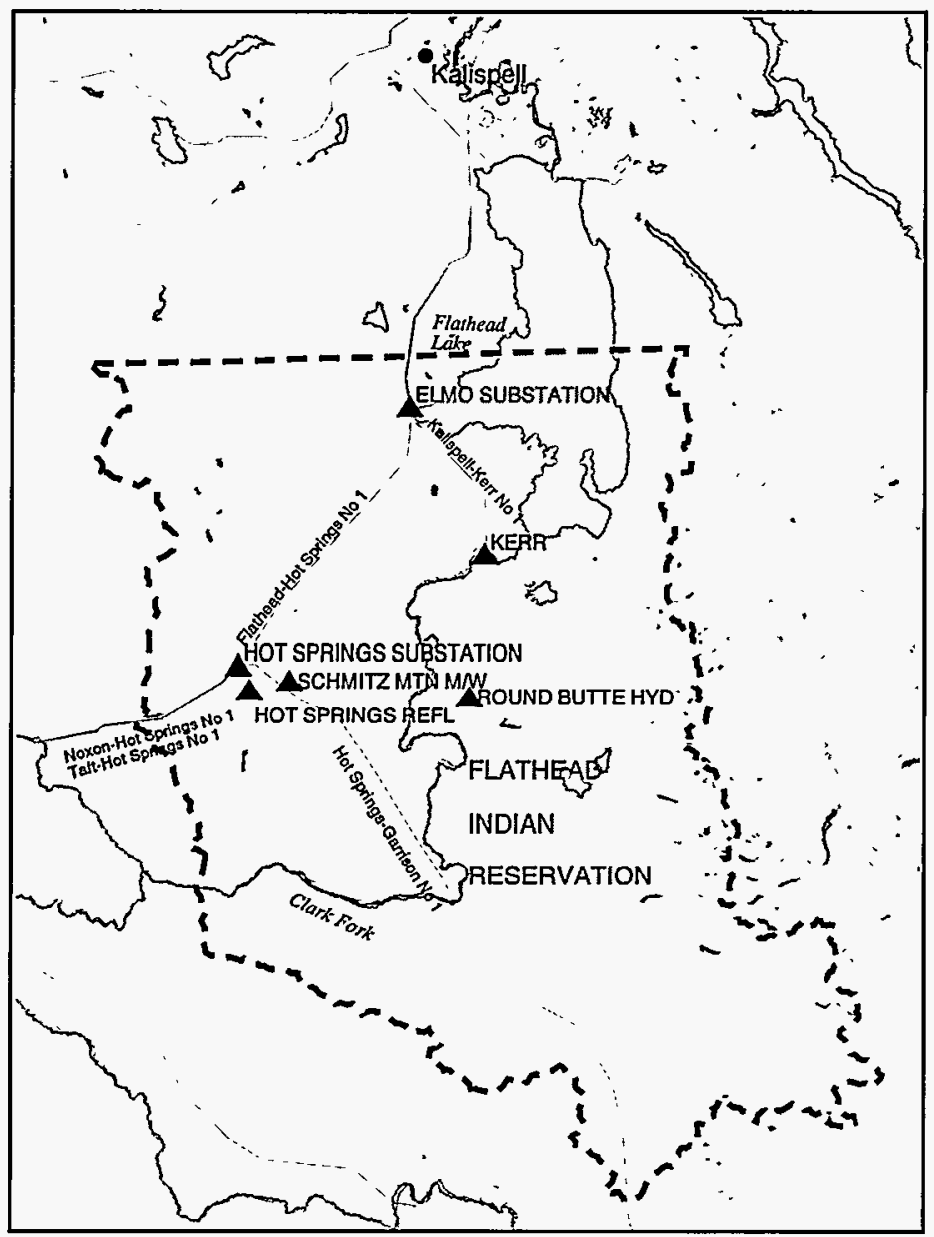

once again everything will be clean and all will be beautiful for the eye to behold; a time when spiritual, physical, mental and social values are inter-connected to form a complete circle.

The elders say that we were placed on this earth as one Salish speaking people. Eventually because the population was growing and food was becoming more scarce, the people decided to separate. The Salish became five bands, whose winter camps were spread between the Bitterroot and Three Forks areas, including Butte, Helena and the Big Hole. The Pend d'Oreilles ranged along the Upper Flathead River drainage, and the Kalispels lived in the Camas Prairie area. The hunting, fishing and gathering territory of the Salish-speaking tribes ranged from the plains of eastern Montana to North Idaho and eastern Washington.

The earth was good to the Salish. It supplied a variety of food in abundance and furnished the raw materials for making lodges, tools, clothing and game. The covering for the lodges came from the buffalo. Clothing made from the skins of the deer and elk, and decorated with porcupine quills colored with natural dyes. Most tools such as needles, mauls and grinding stones were made from wood, bone and rock.

Very few white traders arrived in the area until the early 19th century, and the tribal hunting, fishing and gathering economy predominated in Montana until the arrival of the Pacific Railroad, completed in 1883. The exception to this was the fur trade, which had a great impact. While many preferred the traditional ways well into the 
20th century, the Indian people adapted readily to the use of metal, glass and cloth. Following the completion of the railroad, the way of life slowly changed to an industrial market economy, based on farming, ranching, logging, sawmill work and general wage work.

The presence of the Creator in all things was a spirituality the Salish always had. When their own prophet, Shining Shirt, told them about those that wear long black robes, they were eager to have them bring "Their power" to them. Several Iroquois came from the east and lived among the Salish. They brought with them news of the powers of the Blackrobes and taught them a new way of prayer. Journeys were made east to St. Louis to request the Blackrobes to come to the Salish. The first expeditions brought death. Four expeditions to the east were made in the 1830s. Finally, in 1839, the Jesuit Missionary DeSmet arrived and established the St. Maries Mission in 1841. The missionaries brought to the Salish the Good News. It was not a story full of love. The faith journey was full of struggles and hardships and animosity and mistrust.

New surroundings, the schools, slowly changed the ways of the Indian people. The gifts of healing and strength of the medicine bundles and medicine men, became hidden. Endurance and survival through domination by the ways of the white man became the source of strength of the young men and women of today. They survived through alcoholism, wars, termination, relocation, prejudices, intermarriage, etc., and this all continued to make them a people of strength and a people living in the presence of the Creator.

After being forcefully deprived of much of their land when the reservation was opened to white settlement in 1910, the tribe has worked hard to regain control over tribal affairs and reestablish their economic independence.

In 1936, the tribe was formally organized as the Confederated Salish and Kootenai Tribes of the Flathead Indian Reservation governed by an elected tribal council. The tribes own one of the most valuable hydropower dam sites in the Pacific Northwest and have leased it to Montana Power Company. Tribal timber is harvested on a sustained yield basis and supports a portion of the reservation population.

Education of the young people has received special attention. The tribes operate a Job Corps training center for young Indian people from all over the west. The tribes also sponsor an Indian high school whose major philosophy is to teach the tribal culture. The local Indian communities are getting more involved in the operation of the local public schools, which educate most of the Indian children. The Salish Kootenai College was established in the mid-1970s and now serves almost 500 local Indian and non-Indian residents.

There are approximately 6,700 enrolled members of the tribes. They are representatives of several Salish, Kootenai and Pend d'Oreille bands. The reservation is composed of 1,250,000 acres of forested mountains and sheltered valleys just west of the Continental Divide, including the south half of the Flathead Lake.

The Salish and Pend d'Oreille speak slightly different dialects of the Kalispel Language. The Kalispel language is part of the Salish family of languages spoken by many tribes of the Pacific Northwest. The Kootenai of the reservation speak a totally different language. Almost all of the tribal members now speak English as a result of years of government and mission schooling. Many young people today, however, are attending classes to make a special effort to develop language skills in Salish. Again, because of the dominance of the white culture over the Indian culture, today's generation of Indian knew little of the cultural values and traditions of their ancestors.

A small group of Indian leaders and traditionalists valued highly the traditions and culture of the ancestors, especially the spirituality of being Indian. They were determined that the culture of their ancestors was the only legacy that 


\section{Salish-Kootenai College}

Salish Kootenai College is a tribal college offering Bachelor of Arts degrees, Bachelor of Science degrees, Associate of Applied Science degrees, and Certification and Apprenticeship programs. The College is located on the Flathead Indian Reservation.

Formal education for the members of the Confederated Salish and Kootenai Tribes began with federal government contracts with parochial school, public schools and off-reservation boarding schools. The Indian did not have much to say in the development of policies that governed the educational agencies serving them. The result has been an extremely large number of Indian people not graduating from high school and few entering college. Only a very small number of tribal members have graduated from college.

In an attempt to improve education, the Tribal Council of the Confederated Salish and Kootenai Tribes established Two Eagle River School, which serves grades 9 through 12, and Salish Kootenai College.

The following objectives have been adopted by the Salish Kootenai Board of Directors:

- To provide post-secondary educational opportunities for Native Americans in the following areas: degree programs; vocational training; college transfer programs; community service; Indian Culture and History; and adult education.

- To assess the needs, talents and aspirations of the residents of the Flathead Indian Reservation and to provide a multifaceted education program in recognition of the desires of the Flathead Indian Reservation community.

- To foster and conduct such research and development activities necessary for efficient provision of post-secondary educational and developmental opportunities on the Flathead Indian Reservation.

- To assist with the community development and economic development needs of the Flathead Indian Reservation.

The Northwest Association of Schools and Colleges granted full accreditation to Salish Kootenai College in December, 1993.

All prospective students must apply for admission. The criterion for admission is any one of the following: diploma from an accredited high school; G.E.D. certificate; meet the ability to benefit standard determined through the College testing program.

kept them unique from the rest of the society. The groups fought valiantly to become a necessary part of the tribal government to perpetuate their existence. They gathered oral histories from the elders, developed culture curriculum, and provided consultant services to the schools and agencies. They became a catalyst for renewing cultural activities and began an arduous task of protecting tribal historical and cultural resources.
The elders were supporters of these groups and after ten years have become advisors to the tribal council and a strong advocate of tribal sovereignty.

Those that kept the spirituality of being Indian continue to have hope. Hope for survival of the Salish people, and hope for saving the earth through the spiritual truths of Native Americans. There exists a belief by the Salish that there is a 
relationship of all the Creator's works. There must exist a multidimensional balancing of all these relations and man must not disturb the balancing much longer. The people must let those that dominate our world know that man, the animals, the plants and minerals, and all things are the earth, and we must be respectful.

\section{THE SALISH TRIBES}

Pete Beaverhead tells us that at one time the Pend d'Oreille, Salish, Kalispel, Spokane, Coeur d'Alene, the Shushawap and Colville Indians were all one tribe speaking the same language. In the immediate vicinity of today's Flathead reservation lived three main tribes according to Mose

Chouteh: the Pend d'Oreilles, the Kootenais and a band of Tunaxen. The old people told Mose that the Tunaxen lived near Moiese where they were plagued by smallpox until only a small band of about ten camps remained. Mose said they moved through St. Ignatius to the plains where they settled with another tribe.

The Salish and several large bands spread throughout Montana from the Bitterroot Valley to the Yellowstone. Epidemics and war with plains tribes led to the eventual concentration of the Salish in the Bitterroot Valley. Mitch Smallsalmon said that a band of Kalispel split from the Kalispel Tribe in Washington and settled along the river near Perma, and later at Camas Prairie. He says that the Kalispel Indians are what white people call the Lower Pend d'Oreilles.

The tribes that eventually became members of the Confederacy made by the government treaty of 1855 were four. The Lower Pend d'Oreilles and Kalispeis who made their homelands in Camas Prairie and St. Ignatius were the first two. They shared hunting grounds to the north with the Kootenais who were the third tribe involved. The Salish, the fourth major tribe to become treaty participants, were removed from their homeland after a long bitter struggle.

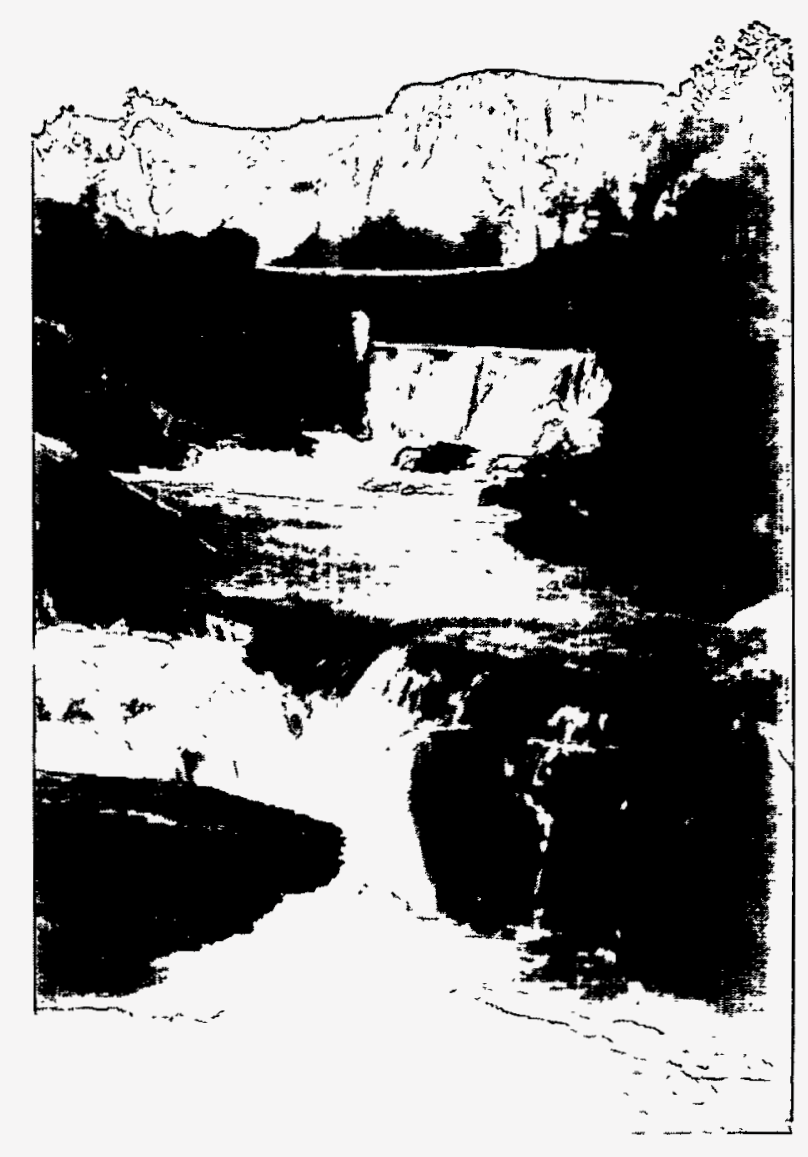

The white people now call all the Indians living on the reservation Salish. This probably started back in 1805, when Lewis and Clark befriended the Salish. Like typical white explorers, they thought the Salish were a tribe of the Flatheads who lived on the Pacific coast, and misnamed the Salish the Flatheads. The name has stayed with the tribes since.

From tribal elders Eneas Pierre, Agnes Vanderburg, Mitch Smallsalmon, Mose Chouteh, Pete Beaverhead and Pete Pierre, we have learned that for the most part, the culture, food gathering and hunting cycles of the Salish, Pend d'Oreilles and Kalispels were very much the same.

The quest for food began in the early spring with root digging and continued throughout the seasons. The primary food was the bitterroot. This gathering of roots and berries by the women 
continued throughout the growing period. Other food collected were camas bulbs, tree moss, onions, Indian potatoes, carrots and many other root bulbs and berries. The men hunted in the early summer, and fished for salmon and trout. Pete Beaverhead and Agnes Vanderburg comment that the quest for food was a continuous yearround event.

In the fall, root digging was emphasized with picking of berries. The first berries picked were strawberries and serviceberries, then huckleberries, chokecherries and hawthorne berries. In late fall the men concentrated solely on hunting. The women spent this time drying meat and preparing the hides for robes or buckskins. The winter months were spent trapping for furs and sometimes fishing. This was the time when the women spent a great deal of their time repairing old clothing and sewing new garments. The elders of the tribe spent the evenings and nights relating coyote stories and stories about their ancestors to eager listeners both young and old. These narratives explained natural phenomena and illustrated moral principles to children.

Pete Beaverhead tells us the stories of buffalo hunting on the plains that he heard from his parents and grandparents. Early in the morning scouts went out to find a herd. If a herd was found, they returned to camp. The chief by this time would have appointed a temporary hunting chief. The men would kill two, sometimes three animals, from the buffalo herd. Blind Mose's parents and ancestors hunted on the plains and stayed from spring to late fall. This was sometimes an annual event for different members of the tribes. At times the neighboring $\mathrm{Nez}$ Perce or Coeur d'Alene joined these hunting expeditions. On the buffalo hunts there was always an extreme danger of Blackfeet or other plains Indians raiding the horse or attacking the party. Before they had horses and guns, Salish hunted by surrounding and stampeding animals over cliffs. The buffalo was an inexhaustible source of food and supply for the Salish.

The hunt for buffalo and warfare with the plains tribes made life very hazardous for the Salish. This was also an opportunity for warriors to improve their wealth and social status. The Salish acknowledged wealth by horses, ample robes, food and clothing. The counting of coup ranked high war honor for the Salish men and this along with other factors determined the selection of a chief, according to stories told by Pete Beaverhead.

Each tribe had a head chief, a sub-chief, and several small chiefs. The head chief is said to have been the leader of the tribe, but as a rule he consulted with other chiefs in matters of importance.

If the tribe divided, the head chief took charge of one part and the sub-chief took charge of the other part. The small chiefs regulated the welfare of the camp, the safety and comfort of the people, and made regulations regarding camping, firewood, horse herds, scouting, hunting and guarding the camp.

\section{EARLY HISTORY OF THE SALISH}

Around 1820, a small party of Iroquois under Ignace La Mousse - Big Ignace as he was known by the local Indian people - reached the Salish country, married and became members of the tribe. They taught the Salish about the medicine of the Blackrobes. The Salish, recognizing the prophecies of one of the elders, Shining Shirt, made arduous efforts to learn more.

In 1831, the Salish sent four delegates to St. Louis to secure Blackrobes for their people. This first attempt was unsuccessful as two of them died while in St. Louis and two died on the way home. When the Salish learned the situation, they sent two young French-speaking Iroquois whom received promises from the Bishops to send Jesuits in the following years. After waiting 18 months, a third delegation was sent, but were killed by Sioux 
while en route. The fourth delegation sent in 1837 succeeded when Father Desmet received an assignment to establish a mission among the Salish.

Mary Finley Nile's grandfather, Eneas, was with this group. She was told that when her grandfather died some months after returning, his legs were still swollen from the poisoning incurred in the long marches through the prickly pear. One of his companions and one priest were killed by hostile tribes, but her grandfather lived to finish the journey and help in building of St. Mary Mission at Stevensville.

This fulfilled the vision of Pete Woodcock's and Agnes Incashola's great-grandfather, Shining Shirt, who was told, "When you grow up there will come men wearing long black dresses. They will teach you about ?Amotqen, the good spirit who sits on top, and about ?emtep, the evil one, who sits at the bottom. From them you will learn to live your life on earth."

Father Desmet then began to work with the Salish. St. Mary's Mission, the first in Montana, was established in 1841 in the Bitterroot Valley. The priests taught the Salish religious teachings along with farming, milling, carpentry, and other skills.

The chief, Big Face, or Standing Grizzly Bear, worked arduously with the Jesuits, as did his nephew, Victor, in learning the religion and in encouraging their people.

In 1850, the St. Ignatius Mission was established on the Kalispel Indian Reservation at Usk, Washington, but was moved at the request of the Indian people in 1854 to the present St. Ignatius Mission, Snye'lmen, the old winter camp of the Kalispel and Pend d'Oreilles. According to the elders, the name Snye'lmen comes from the elk that surrounded the camp.

The mission started to grow. Flour and saw mills and schools for the Indian children were soon erected. The Sisters of Providence who began a girls school arrived in 1864. An agricultural and industrial arts school for boys was built. Several years later the schools were destroyed by fire. This didn't discourage the efforts of the missionaries. In 1890, the Ursuline Nuns arrived and began a kindergarten which later expanded into a grade school and a high school. The Sisters of Providence then began devoting their time to medicine. They eventually operated a hospital. As more and more Indian children were educated at the mission school, and the nuns discouraged the use of the Indian language, the language of the people began to be forgotten. This in turn affected the ability of the elders to transmit traditional religion and learning, and began driving a wedge between the generations.

The Ursulines were forced to close the mission boarding school in the 1960s, but continued operation of a day school until 1972.

The Sisters of Providence operated a hospital until 1976.

After the arrival of the Blackrobes among the Salish, the United States Government contacted the three tribes asking for a treaty council. In 1855, Isaac Stevens, territorial governor for the Washington Territory, met with the chiefs of the Salish, Pend d'Oreille and Kootenais at Council Groves near Missoula for treaty negotiations. The head chiefs then were Victor, Chief of the Salish, Alexander, chief of the Pend d'Oreilles, and Michel, chief of the Kootenais. R. Ignatius Burns reports in "A Jesuit at the Hellgate Treaty of 1855," Mid-American Historical Review, April 1952, that the Lower Pend d'Oreilles did not participate in the treaty.

The treaty council met in July. Stevens wanted the three tribes to live on one reservation. Victor did not want to live on Pend d'Oreille land. Alexander and Michel wished to stay near St. Ignatius. After much deliberation, an agreement was reached for the Pend d'Oreilles and Kootenais to stay on the Jocko Reserve. Victor's band would not move until the President made a survey of the two reservations. 


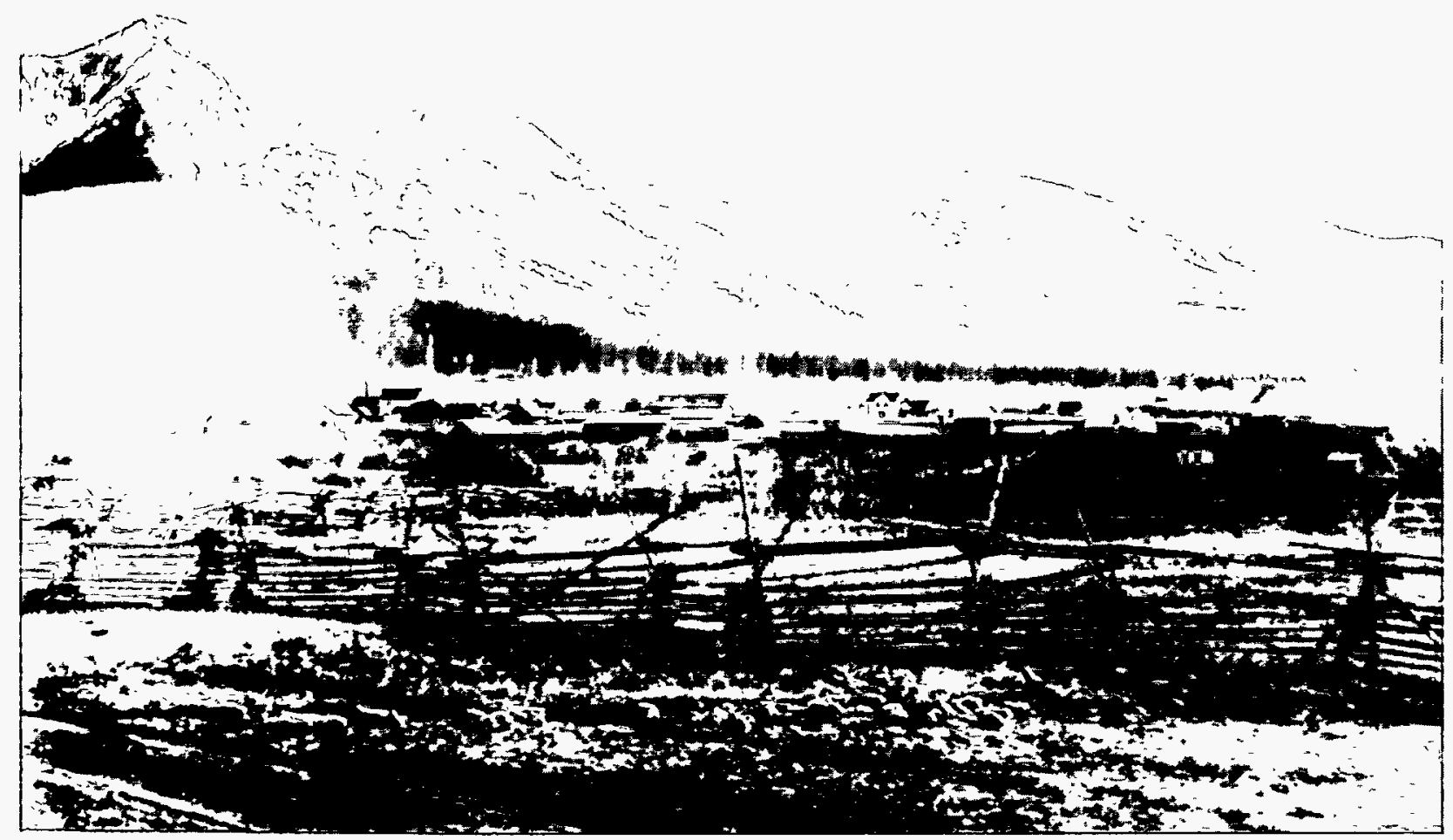

The Salish continued pursuing their livelihood and journeyed east to hunt buffalo. Tony Charlo, the Great-grandson of Victor, said that during one of these trips, Victor was killed in battle with one of the plains tribes. He was buried there on the plains with no marker because people feared the enemy would molest his grave if they knew its location. The Salish then chose Charlo, Victor's son, to be their next chief.

Charles Jones was appointed Indian agent and because of pressure from the whites in the Bitterroot Valley, a council meeting was conducted with the Salish. He wanted them to become citizens of the United States and take lands under the Homestead Acts. Arlee and Joseph Ninepipes, both sub-chiefs under Charlo, thought that moving to the Jocko might be better. Charlo refused to move.

Governor Potts asked the President to order a survey in compliance with Steven's treaty and order the removal of the Salish from the Bitterroot. Although he had not conducted the required survey, President Grant then issued an executive order on November 14, 1871 for the removal of the Salish to the Jocko Reservation. Congress appropriated money to pay for the removal and to compensate for improvements the Salish had made on their land. It also provided for the survey of the Bitterroot above the mouth of Lolo Creek and provided that any Indian head who renounced his tribal relations might select land to be patented in his name.

In August the Salish chiefs met James Garfield who was empowered to negotiate a contract with the Salish for their removal. After a couple of days of discussion, Garfield invited the chiefs to inspect the Jocko with him. Garfield learned after their visit that the Bitterroots Chiefs were divided on the question of removal. Garfield then drew up a contract, had it translated, and Arlee and Joseph signed with their marks. Charlo refused. Garfield thought that Charlo wanted to talk further with his headmen at home. Arlee and Joseph felt that if preparation were made 
according to the contract, Charlo would finally consent to go with the tribe.

Garfield then put his understanding in writing for the territorial superintendent, which said, "In carrying out the terms of the contract made with the chiefs of the Salish....I have concluded that full consultation with you to proceed with the work in the same manner as though Charlo had signed...." When the contract was printed in the commissioner's annual report, Charlo's mark appeared as if he had signed the original.

When the report was printed, it appeared as if Charlo had consented and signed the agreement. This apparent fraud caused the chieftain to become further embittered against the white man who had taken his country and was making a strange life for him. Although all of this was going against Charlo, he would not take sides when Chief Joseph asked him to join him in 1877 (the Nez Perce War). In fact, Charlo told the Nez Perce that he would fight against them if they attacked whites. In 1883, Senator George Vest and Martin McGinnis had another council with Chief Charlo. By this time, Vest had tracked down the original 1872 agreement and proved that Charlo's claims that his signature was forged were true. This time they invited him to visit Washington to talk over the matter. After the trip to Washington, Charlo still would not move, but said he would allow any of his people to accept patents. Charlo was told he could live in the valley as long as he remained peaceful.

Arlee, who had been appointed chief of the Salish on the Jocko Reservation, died. Charlo's people were getting hungry. Finally, on October 10,1891, Charlo declared that the time had come. He called his people together, they prayed and announced that they would go. Several days later, following an all night feast, the Salish assembled at dawn, loaded horses and wagons, and started for the Jocko Reservation.
Mary Ann Combs remembers when they had to move. She said it was the government who made them move out, not the neighbors. When Charlo refused to give up his lands, he was told the soldiers would bring him in if necessary. At first, they had not believed they would have to go, and it was about two years before they were forced to leave according to a Char-Koosta article by Don Matt, Volume 5, Number 14.

She also remembers all the people crying about having to leave. They dragged their teepee poles, although not everyone used a travois to carry their things. All the farmer's fences along the way were old, wooden type fences. She remembers the spots where they camped. The first place was the other side of Missoula.

Charlo held prayer in the evening at camp. They camped again on this side of Missoula near Schley. They stayed there for two more days at a place known as Two Creeks in Salish.

Two people were hurt during their journey. Louise Lumphry, wife of Joe, fell when her horse spooked. Her hip was broken and she was left crippled. Another man fell near Schley and suffered a broken shoulderblade.

Those people at the Jocko church saw shirtless braves in red war paint and their best tribal dress galloping up on swift horses. They were firing their rifles in the air and singing. The women came behind, crying. The Reverent Phillip Canestrelli got all excited thinking they were under attack.

Mary Ann's future husband, Louis Combs, was there among the crowd awaiting Charlo's arrival. Being young, he panicked and tried to run and hide, but he was stopped and calmed by a woman who was a sister to the chief of the reservation band.

Mary Ann felt they were well received by the people on the reservation. The government, however, failed to come through with the promised houses for those making the move. Five buildings were built near the Jocko church for the 
leaders, but Mary Ann's father was among those left without help. One of her biggest complaints about the way the government handled things here on the reservation was they evicted Charlo's widow from her home after he died.

When the Salish were put on the reservation, the whites felt that the Indians occupied far more land than they would ever use. Major Ronan, the Indian agent and a friend of the Indians at the time, died. Following him, Carter was appointed agent. In 1897, a new agent, W.H. Smead, was appointed. A commission was appointed by the government to negotiate with the Indians to sell part of their reservation. Charlo said he would not sell a foot of land. Isaac Big Knife, chief of the Kootenais, wanted to know about the boundary lines and said they had better hunt some people who wanted money more than they did. Louison, a tribal leader of the Pend d'Oreilles, stated he wanted to go to Washington. Charlo forbade his people to discuss any sale.

A national policy had been established for opening reservations to the whites. Joe Dixon introduced a bill to Congress in 1903 to allot lands to the Indians and open the remaining lands for settlement. Congress passed the bill in April 1904. The Indian office sent an agent to enroll tribal members. The agent gave Indians new names because the commissioner wanted the Indians to adopt family names like the whites.

After a year, the agent submitted his final enrollment of 1,656 persons. The lists were reviewed and found that the Camas Prairie Kalispels, the Lower Pend d'Oreilles, were not enrolled. A new enrollment was made and completed in 1905. This enrollment named 2,133 persons. There were 640 Pend d'Oreilles, 557 Salish, 556 Kootenais, 197 Lower Pend d'Oreilles, 135 Spokanes, and 48 from other tribes.

Chief Charlo was making every effort possible to get the government to stop forcing Indians to become white men. He journeyed to Washington in 1905 and in 1906 sent Antoine
Moiese and Alicot to President Theodore Roosevelt to halt allotments. They failed to change the government's decision.

Despite petitions, trips to Washington and persistent opposition, allotment of the reservation closed on September 1909. A series of amendments to Dixon's Act to open the reservation reserved land for tribal uses, for townsites, for power installations, and for a national bison range, and electric generation and reservoir sites.

On July 14, 1909, the Flathead was opened for settlement. As the appraisers worked, Qeyqeysi, Charles Mollman and Sam Resurrection were working gathering signatures from the Indian people protesting the opening of the reservation.

On January 10, 1910, Chief Charlo died. Martin was elected to replace him as Chief. Fifteen days later, the federal government announced that the lands would be opened to entry by whites on April 1, 1910. Approximately one million acres were opened. Soon after President Taft signed a bill authorizing Indians to sell their allotments making more land available to whites.

Pete Beaverhead recalls that day. He said, "All of a sudden one day a paper came up. A picture on a postcard of a whiteman and two Indians were on it. They had the names of Joe Dixon and the Indians, Joe and his wife. He wasn't a chief or boss and had no business here. He was good for nothing, but Joe Dixon just used him and had him witness papers to open the reservation to settlers and to buy our land. This is when the white man moved in. They liked our mountains and the land." Even though Joe's consent did not affect to opening the reservation, the Indian people felt that even some of their fellow tribesmen were against them.

In 1934, Congress passed an act called the Indian Reorganization Act, allowing Indians the option of incorporating and governing themselves through a tribal council. A business committee had formed and pushed the tribe into incorporat- 


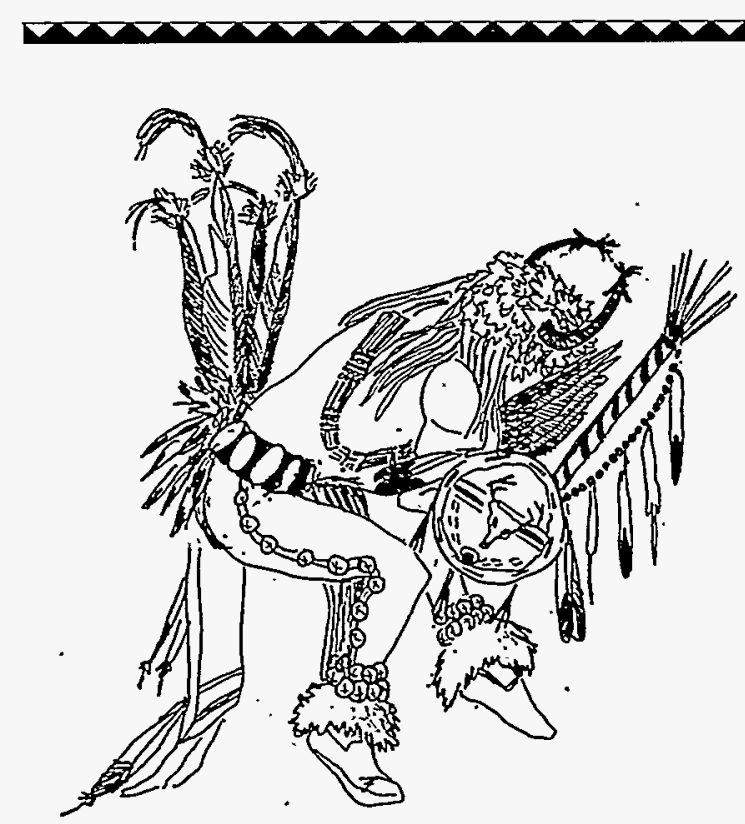

\section{Salish Dances of the Past and Present}

Blind Mose and Agnes Incashola related to us information on how celebrations and dances were done around the turn of the century. The culture committee and pow-wow committee have used this information in helping with our current celebrations.

They said that Indian leaders would meet to discuss plans for the celebrations and to collect donations of cows and money. Baptise Qeyqeysi was looked up to among the Pend d'Oreilles as a leader. He, along with Joe Peone, Lome Joscum, Joseph Standing Grizzly, Ben Nenemay, Massyal and Tom McDonald, Sr., were some leaders involved in preparations. Rations, camp sites, teepee poles, war dance chiefs, were all part of the preparations to be made and chosen.

The first celebrations were times of enjoyment. The opening event was a memorial dance to honor their dead. Following this, the celebrations were opened for general entertainment and fun.

The canvas dance was usually the next dance done after the memorial if there was going to be a raiding party. The men would start early in the night and sing from camp to camp, usually going until morning. Sometime during the night or morning the raiding party would leave. As the times changed for Indians, the canvas dance has become only a form of entertainment.

The next morning, some people would get on their horses and parade around camp. Some would be fully dressed in dance outfits and horse trappings. That afternoon, another parade would be held with row upon row of Indians on horseback singing their parade songs.

A favorite form of entertainment at the early day celebrations was the re-enactment of battles. Men would get together beforehand. Sometimes, Agnes recalled, the spectators unknowingly became victims of the battles.

Sometimes during the celebration, a scout would come riding into the camp and the people would ride up to him. Someone would lay a blanket in front of him and hit him with a stick. The people would be standing in rows in front of him rocking from side to side as they were singing. He would then tell what he had seen. This might have been an enemy, recounting a battle, or maybe he had seen something being prepared for the celebration, like the butchering of a cow. The people who had horses would get on and attack, singing a battle song.

Following the battles someone would come walking through the camp hollering: "Lend me your wives, lend me your daughters, lend me your grandmothers...we are going to scalp dance." The women would be told by their husbands and parents to go. They would all go to a certain camp to get their faces painted. They would be wearing men's clothing. During this time there were special songs for each, even while getting faces painted and while walking to the dance arena. The leader would then tell the ones to be first to make their rounds around camp. Off at another camp, another group of women would leave. The first group of women by then had completed their round and were in the middle of the dance pavilion.

ing under this act. This act also dissolved chieftainships. Martin Charlo, chief of the Salish, and Chief Koostahtah of the Kootenais, were to become honorary members of the tribal council. On their deaths, the tribes would have no more chiefs.
The chiefs of the Pend d'Oreilles and Camas Prairie Kalispel were not named.

From that time on, the Indian people's numbers have dwindled and the culture and traditions and language have withered. Today, however, there 
As all the groups of women got to the dance area, the scalp dancing would begin. Sometimes during the dance some of the women would leave and return dressed in old ragged clothes with darkened faces. One of the women would be carrying a stick. She would go behind the drummer and stand there holding the stick above the men's shoulders. If she placed a stick on a man's shoulder, then she became the man's wife. But if he should brush the stick off, then that would mean he didn't want her. Now, when we do the scalp dance, it is just a reenactment, not a real marriage proposal. After a few more songs, then the one with the scalp would make a round in the dance arena showing off his scalp, and that would be all.

The lost article dance is another dance that would be done at the celebration. A song was sung to gather the warriors who were to tell of their great deeds. In the dance, items were left on the ground. The dance ended when the warrior picked up the lost item. The warrior told of how he had taken certain items during battle. There were many stories told. When the stories were finished, a certain song was sung to signify that the lost article dance had ended and the warriors would be escorted out of the dance circle.

In later years when a person finished telling of his deeds, his relatives would throw things - blankets, shawls, money - for a giveaway for visitors and friends. All day long, Agnes said, they would be giving things away.

War dancing would go on at the celebrations whenever no other activity was taking place. Each man had his own style of dancing. A great number of songs are sung for each war dance. There are fast and slow war dances. The older type of war dancing, as said by the elders, was done similar to the crow hop.

The round dance, which is sometimes called a circle dance, is a social and happy dance because it is meant to get everyone to participate. The gift dance was also done during the round dance. When one person wished to give a gift to another, he merely escorted the person inside the circle of dancers and began round dancing around the drum. When a song ended, the gift was presented. Generally, announcements were made as to who gave the gift to whom.

Many years ago a man resting in a field woke and heard singing near him. Very carefully he raised up and saw the prairie chicken singing and dancing in prayer. The man returned to his people and showed them how this dance was done. Consequently, the dancers would strut around and show off as the prairie chicken. In later years, the prairie chicken dance became a specialty and is used in competitions because of its different style of drumbeat.

The fancy dance was introduced among the Salish through visits to other tribes. This very colorful and exciting dance is used in the finals of championship dancing. This attracts many of the younger dancers throughout the country to demonstrate their various steps and fancy movements. The dance judges have their work set out for them.

The snake dance is done to begin a war dance. It was led by a chosen man who gathered the dancers at a designated spot, generally at the celebration chief's camp. The dancers danced in a single file towards the dance area with the leader weaving and doubling back in a fashion of a snake. The drummer and singers followed the group singing the snake dance song.

The flag song was treated with respect. It is as the national anthem is to non-Indians. The Indian flags were made of eagle feathers attached to a long staff or lance, and was carried by great warriors. When a warrior carried the Indian flag, he was well respected because he had earned each of the eagle feathers. The song was sung to open each performance.

The home sweet home, a farewell song, is a closing prayer song which is sung at the end of celebrations. As the celebration begins with a prayer, a prayer closes the celebrations for all visitors and travelers, that all might be together for another year.

is an attentive measure by the young people and by tribal leaders to revive the culture and the language. Many of our schools have Indian studies programs and our state has recognized in their constitution the unique heritage of the American Indian.
Although the past has been a long struggle for our parents, grandparents and ancestors, the Salish, Pend d'Oreille and Kalispel cultures and traditions have survived and hope to be stronger in the future. 


\section{THE KSANKA A.QOSMAKNIE (THE KoOtenai PEOPLE)}

Frequently in the history of the relationship between Indians and whites, tribes are commonly known by names that are different from traditional names. This is also true for the Ktunaxa Nation. Members of the Ktunaxa Nation are often referred to as Kootenai, which has led some people to believe that Ktunaxa and Kootenai are two distinct groups. In fact, Kootenai is more commonly used than Ktunaxa even when referring to ourselves. But, in our language, "Ktunaxa" is the term that has meaning for us. We have long interpreted "Ktunaxa" to mean "eats food plain," as in taking coffee without cream or sugar (even though most of us use both in our coffee). This is the meaning of one form of this word, but "Ktunaxa" is also a shortened version of words that mean "to pull an arrow out of your enemy and run it through your lips, licking off the blood." The closest translation in English might be "eats fresh blood." Perhaps our ancestors felt that this name might increase racial fears and perpetuate discriminatory attitudes and policies and thus softened the interpretation. However, we feel that it is no longer necessary to hide the true interpretation and, in fact, are quite proud of the spiritual power exemplified by the historical translation of Ktunaxa.

Ksanka (like Ktunaxa) has been softened in it's interpretation and has commonly been said to mean "standing arrow." "People of the Standing Arrow" is a well-known interpretation for "Ksanka A.qOsmaknie." However, Ksanka is also a contraction of the word "Ksahanka," which signifies "poisoned or bad arrow," and our name for ourselves could be translated "People of the Poisoned Arrow." A.qOsmakniE means "people" in the Ktunaxa language. In a broad sense all people are A.qOsmakniE, but like most cultures in the world, when we refer to people we are actually referring to "our" people. This ethnocentrism is reflected in most languages of the world whereby different cultures view themselves as the actual "real people." And so it is true for the Ksanka A.qOsmakniE.

\section{POLITICAL STRUCTURE}

There are seven bands of Ktunaxa today. The settling of the various bands on separate reservations/reserves has given each band a distinct post-contact history. However, the bands maintain a close relationship through a common language and culture. While each band is very independent, and distinctive in various ways, we regard the people of the other bands as our brothers and sisters. The seven bands of the Ktunaxa Nation include two bands located within the boundaries of the United States and five bands located within the provinces of Canada. The Ksanka have been referred to as the Dayton Creek or Elmo Kootenai of the Confederated Salish and Kootenai tribes of Montana.

There were other names given to us by neighboring tribes according to what they considered distinctive about us. Long ago, for example, the Mukwu'kniE (Flathead or Salish people), called us "Skalzi" (sqaas.), which is a derivative of their word for "sign language." They called us this because in the past the Kootenais always used sign language when they communicated, even with each other when it was not necessary. They would speak the language and sign at the same time. And according to some of our elders, the word "Kootenai" is a Blackfeet word for "water people." Nevertheless, the Ksanka A.qOsmakniE of the Ktunaxa Nation is our way of referring to ourselves.

\section{ORIGIN}

The actual creation story of the Ksanka A.qOsmakniE is very long and is considered sacred, meaning it should not be told verbatim to foreigners. Suffice it to say that, in general, our beliefs about our origin are similar to other Native 


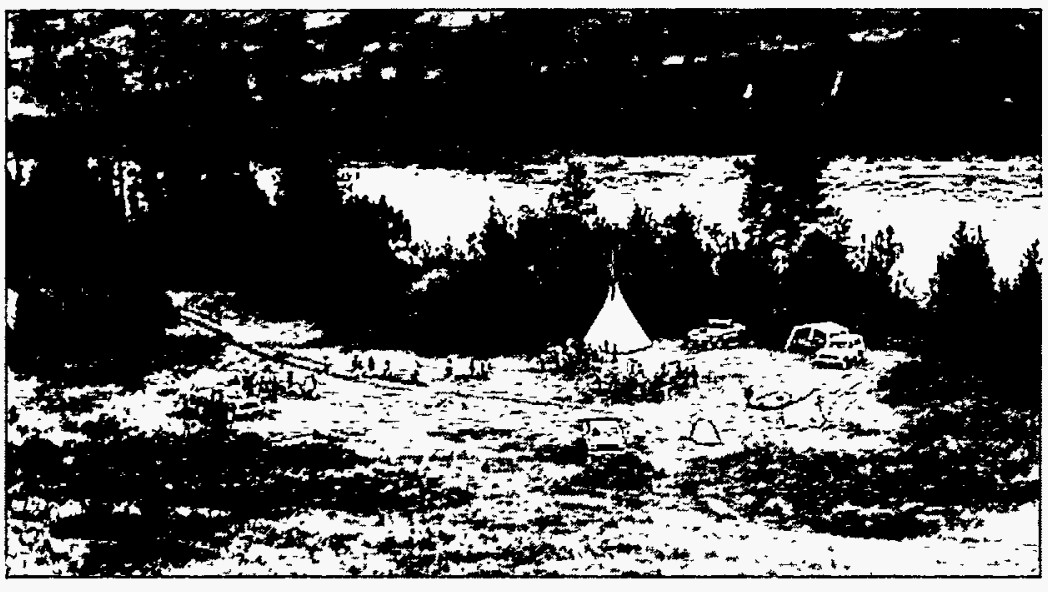

American tribes. We believe in a creator of all things known to us.

Creation happened in phases whereby human habitation of the earth was preceded first by spiritual habitation and then by physical or animal habitation. The major purpose for the spiritual period was to prepare the earth for humans. The spirits who inhabited the earth in the beginning communicated with the creator and each other through songs.

The second phase of creation happened when the spirits took a physical form. The spirits decided which form they would take and each form was to help humans in some way. The sum total of all creation was a balanced ecosystem. So, in this way we not only know that all things today (whether animal, vegetable or mineral) have a spirit but also realize the delicate balance that must be maintained throughout the system.

The spirits kept their method of communication throughout the entire process of taking on physical characteristics and would later teach their songs to individual humans whom they wanted to help. The humans would, in turn, teach the songs to their children, and so on. Thus, humans were provided an avenue to communicate with all those who have gone before, all the way back to the beginning of time. Maintaining this connection has become the single most important function of human existence and continues to this day.
While scientific evidence dates a Kootenai presence in the Rocky Mountain region as far back as 14,000 years ago, the Ktunaxa trace their roots back to the beginning of time. Our band, the Ksanka, are the original inhabitants of Montana, with descriptive histories that chronicle geological formations and other natural phenomena in the region. Some of the most significant landmarks in Montana are revered by Ksanka as traces of nother era - an era when animals and other beings ruled the earth and spoke the same language as the Ktunaxa in order to offer The people guidance.

Ktunaxa history describes the evolution of "Aqtsmakni-k" (The people) from the time when the first sun rose in the sky and human beings were equal to the animals. From the beginning of time, the Sun and the Moon were brothers and they produced the powerful life force for all earthly creations. The Sun and the Moon transformed all beings who chose to live on this earth into physical forms and assigned them a domain with complementary roles. The concept of interdependence that maintains the delicate balance of the natural world is intrinsic to Ktunaxa culture. We have always relied on the laws of nature for survival, and we continue to cherish and respect animals as equals.

"I was...surprised...to find the Kootenays were a tribe practically untouched by the...civilization of the West. They had no reservations; they had no agents over them; they received no assistance from the government; ...they lived entirely upon the products of their rivers, lakes and forests: they spoke a tongue unknown to their next neighbors; they kept strictly to themselves and, with the exception of their annual buffalo hunts, they never left their own beautiful mountain-girt home."

Baillie Grohman - 1870s 
The aboriginal territory of the Ktunaxa Nation encompasses three major ecosystems: The Columbia River Basin, the Rocky Mountain Region and the Northern Plains. Early Ktunaxa settlements spanned the Columbia River Basin and the west corridor of the Rocky Mountains, extending from British Columbia to Wyoming and westward onto the high plains of Alberta.

Although an official census was never taken of the Ktunaxa Nation, ethnographic studies estimate an historical population in excess of 10,000 Kootenai people.

With a massive homeland to protect, and keen environmental skills, the Ktunaxa chose to live in distinct bands to maintain their unique life cycles. The seven bands of the Ktunaxa Nation are distinguished by the location they inhabited throughout the winter months. The Ksanka, or the Fish Trap People (A kicqa) reside in the Dayton, Elmo, Big Arm and Niarada communities of Montana. The Wood Land People of St. Mary's band in Cranbrook, British Columbia are called the "A qqami'·k." The Two Lakes people of the Columbia Lake Band at Windermere BC are called

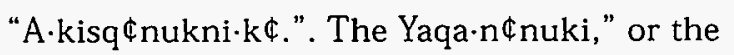
People of the Place Where the Rock is Standing (the Lower Kootenai) reside in Creston, BC; the A kaqiahaixu, or the Meadow People live in Bonners Ferry, Idaho; the Tobacco Plains Band, or the A kanuxuni', live in Grasmere, British Columbia. The Kiitqatwumia't, or the Not Shirt People (Upper Kootenai or Shushwap) hail from Ivermere B.C.

Prior to reservation settlement, the Ktunaxa lived a bi-cultural life-style, possessing cultural traits of both the Northern Plateau and Northern Plains tribal groups. Ktunaxa subsistence was based on seasonal migrations that followed plant and animal production cycles, and coincidentally served to prevent an environmental degradation of aboriginal lands. Food preservation was an integral part of the Ktunaxa life cycle. Seasonal migrations for hunting and harvesting began in the early Spring when bitterroots ripened and fisheries were bountiful. In early Summer, they traveled east of the Rockies to hunt buffalo, returning in mid-Summer to process and store the meat. In late Summer, camas, huckleberries, serviceberries, chokecherries and other plants were harvested. By Fall, big game expeditions were organized and some of the hunters returned to the Plains for more buffalo. The "Aqtsmakni.k" preserved and processed food for the winter cache.

The Ktunaxa life cycle also depended on a commerce sector, which involved agriculture and aquaculture. A unique species of tobacco was cultivated by the Ktunaxa for personal use and surplus trade with other tribes. They specialized in water, fisheries, bird hunting, trapping and other aquacultural activities that were ongoing in Kootenai society.

The Ktunaxa hold many distinctions as the original inhabitants of the Rocky Mountain region, from prehistoric cultural characteristics to modern day customs. By far, the most prominent distinction of Ktunaxa is the isolate language they speak. While scientists classify most indigenous languages into family groups to determine origin and migratory patterns, the Kootenai language has never been linked to any other language in the world. It is an anomaly that effectively contradicts any migration theory for the Ktunaxa. Unfortunately, the Kootenai language is endangered, and unless this generation masters the spoken language, it will become extinct.

Other distinctions of the Ktunaxa include their portable tule-styled summer lodges, called Tanat. The "Aqtsmakni.k" also held the distinction of avid canoeists, trappers and anglers. They excelled in engineering light craft to expedite navigation on some of the most treacherous waterways in the Northwest. Their hunting and fishing techniques were superior to most, even by modern standards. They developed and utilized ingenious devices to augment their technique. 


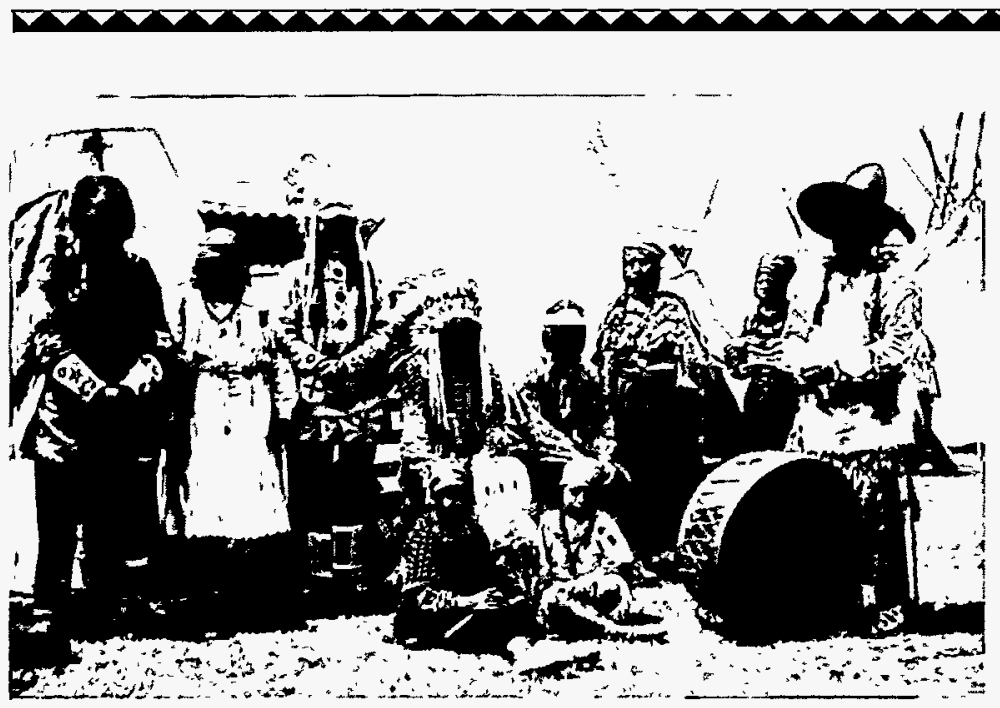

Native people continue to hold onto are the cultural values. The heart of the cultural values center on respect for all creations and maintaining the connection with the creator through all those that have gone before. The cultural values of the Ksanka A.qOsmakniE can best be illustrated through the stories. The following stories are illustrations of Ksanka cultural values. The first story happened before European contact and tells why the Ksanka live on the west shore of Flathead Lake. The second

Traditional Kootenai fish weirs and bird traps were widely sought for their utility.

In traditional society, Ktunaxa produced several goods for commerce and even today, Kootenai buckskin is still considered the best on the market. Buckskin producers take great pride in manufacturing the whitest, softest and most evenly tanned hides in the region. Their exquisite craftsmanship is demonstrated in traditional artwork and apparel that is available from area retailers.

\section{HUMAN HISTORY}

Our history is also similar to that of many Native American nations. Maintaining a balanced respect for all creations was the dominant theme throughout pre-European contact history. This theme continues today, although it has been seriously threatened by acculturative influences. Acculturation happens whenever different cultures come in continuous contact and results in changes in the cultural values, beliefs and behaviors of one or both groups. Every Native American tribe has suffered from forced acculturation which has predominantly affected cultural behaviors such as language spoken, clothing worn, religious practices, housing, transportation and the form of education. Although changes in these behaviors has also led to a certain degree of changes in cultural values, the main cultural component that story is the life story of a tribal elder who has passed on since sharing her story with the Kootenai Culture Program. It shows the effects that acculturative contact had on the Ksanka A.qOsmakniE.

\section{CHIEF CLIFF}

On the west shore of Flathead Lake between the towns of Elmo and Dayton there is a high cliff that can be seen from Highway 93. The Ksanka call this cliff "Chief Cliff" because of the following story. There lived a band of Ktunaxa in the northwestern part of what is now called Montana. The area beneath the cliff used to have many different kinds of berries growing there. When the berries were ripe in the summer the band of Ktunaxa would camp by the base of the cliff to pick the berries. It was during one such camp that the chief noticed big changes in the Ktunaxa people.

One morning he was sitting outside his teepee and noticed an elderly couple making their way back to camp with a load of firewood on their backs. A group of teenagers were leaving camp at the same time and as they passed the elderly couple the youngsters began taunting the couple and made them drop their load of wood. The elder couple huddled together and ignored the teasing until the young group had passed. Then they gathered their firewood and continued on to their 
teepee. The chief lowered his head in shame and returned to his teepee.

The chief told his wife to prepare for war. She took out his best war outfit and gave it to him to get dressed. Then she went outside and brought his fastest, strongest horse and prepared it for battle. She was waiting with his horse when he surfaced from the teepee and mounted. He rode out of camp on a trail that went around the north side of the cliff. As he left camp a group of teenagers were heard to say, "Look at how foolish the chief looks, pretending he's going to war." They laughed and dismissed the thought of him as he went out of sight.

Soon the entire camp's attention was called to the top of the cliff as the chief cried out from there. The chief spoke to the camp. He began by telling them how it used to be when he was a young boy. One of his favorite activities when the camp would be at this spot was to pick a basket of berries and give it to his grandparents who would be sitting and visiting with other elders in the shade. What a great feeling of personal satisfaction it was to see the look in his grandparents' eyes as they enjoyed eating the basket of berries. In those days the young people took great pride in taking care of the elders of the tribe. Being an elder was not a time for hard work. That was left to the young people, as life was thought to be for going around gathering memories to think about while sitting in the shade as an elder. It was good to see the elders walk around with their heads up as proud people, knowing the Ksanka A.qOsmakniE were walking a good road. Nowadays, the elders were always walking with their heads down, only looking directly in front of them as if they didn't want to see what was ahead.

These were the same feelings the chief felt. The Ksanka were becoming an ugly monster and he couldn't bear to watch it happen. He stated that he wouldn't watch it happen to the people. With that said he turned his horse away from the edge of the cliff and rode back out of sight.
When he was several feet away from the edge of the cliff he turned his horse around and with a firm kick in the side his horse galloped to the edge of the cliff and jumped out as far as it could. The chief and his horse let out a war-cry as they fell and were crushed on the rocks below the cliff.

After overcoming the shock, the elders slowly gathered the chief's body to begin preparing for burial. The young people quickly took the responsibility of caring for the chief from the elders and while the elders rested the young people prepared the camp for the ceremony to bury their chief.

After the chief had been buried, the entire camp gathered for a meeting. One by one the people spoke of the truthfulness of the chief's final words. It was decided that the young people must once again instill pride in the people by taking care of the day to day needs of the people. The goal would be to get the elders to walk around with their heads up, knowing the Ksanka were once again on the good road. They would call this place "Chief Cliff" in honor of the chief who had given his life for them. To insure that this would never happen again it was decided that the Ksanka A.qOsmakniE must camp here from this day forward. So, the first thing the Ksanka would see when they came out of their teepees in the morning would be Chief Cliff, as a reminder to be good to their elders on this day. They would tell this story to their children and emphasize the importance of passing the story on to future generations.

Since that day the Ksanka A.qOsmakniE have maintained their main camp within sight of Chief Cliff.

\section{ELDER TESTIMONY: LIFE STORY OF MARY ANTISTE}

"I was born March 24, 1897, in a teepee on Ashley Creek where Kalispell, Montana now stands. At that time my mother said there was only a little store and a post office. My husband, Joe Antiste, was born in a teepee in the Dayton Creek Indian village, 
Dayton, Montana, December 15, 1893. My father, Lassa Stasso, was given the English name of Larsen. His Indian name means 'the third one.' His father, who was part French, was killed in a war before my father and his twin brother, Tony, were born (in Arlee, Montana). His mother was half Ksanka and half Flathead. With his dog, my father was in a cave near Anaconda when he got his power. He was a great medicine man in the early 1900's. He trapped mink over at Swan Lake in the snow, and my mother went with him several weeks before I was born. They traded the mink skins at the old Kalispell trading post for hats or blankets or other goods. My father mostly used traps because guns were scarce, and only once in a great while was he able to have one to shoot animals. He never used $a$ bow and arrows, and his medicine was the Blue Jay. My mother's name was Vivian and her Indian name means 'Gray-headed Woman.' When she died at the age of 53, I took her Indian name. My great-great grandfather wore buckskin leggins, breech cloth and home-made shirt. His Indian name means 'Pinto Coyote.' $M y$ grandfather used bows and arrows and got his own flint to make the arrow points. My grandfather said that when the sky was red in the west when the sun went down, it meant cold or bad weather. When the shy was red in the east there would be snow in three or four days. The grandfolks' thunder and lightning meant an old man called 'Numa' was filling his pipe, and he would kill bad people. I was never afraid of the lightning and thunder; I just thought it meant that it was going to rain. There are a man and woman in the thunder and they are married. It was against our religion to tear up the ground like the white men do. We used the roots and berries that grew for our food, and we never made a garden. We liked to dig the camas bulbs and put them in a gunny sack we got at the Kalispell trading post. We dug a hole and put in rocks, then moss, and then the gunny sacks of camas which we spread out flat, and then another layer of moss. On top of this we covered it over with wild flowers to keep it fresh. On top of all we built a fire. Then the camas and moss would turn black as it baked and got thick. This took three days. We could save the dried camas to have in the winter when it was broken in pieces and boiled. We also like to eat it plain. My grandmother dried berries in the sun to keep them for winter. The wild chokecherries she smashed, seeds and all, and formed patties and then dried them in the sun. When they were dry we would break off pieces to eat. She also boiled this with meat and would thicken the broth with a little flour when she had it. My grandmother scraped a buffalo horn into the shape of a spoon. She also had a black iron pot which stood on little feet. She liked to mix a fresh leaf called 'Mata' with her dried meat and she found these leaves growing along streams. She didn't have salt, but I did. She had rawhide suitcases to keep her food in. She also made cedar bark baskets to keep her dried berries in. These were bound together with strips of willow. When the sides were dry, tops and bottoms were made so the basket would be round. I don't remember exactly how they were made, and when I tried one it tore. Anyway, we had baskets to keep our berries in. My mother's people didn't have beads to work with and they worked their designs with porcupine quills. I wouldn't even know how to do this. It wasn't until after I was married that I started to do beadwork, and I learned it from watching. My grandmother used a buckskin calendar string and knotted it for each day. On Sundays she would make a little cross. Later, a special knot was used for Sunday. I have always lived in a teepee made of canvas. We had deer hides tanned with the hair left on which were used on the floor of the teepee like rugs and blankets to sleep on. At that time it was easy to find lodge poles for our teepees. We moved our teepees to better places that were clean when it got dirty where we lived. The buffalo were gone before my time, and also the hunts over the mountains to the east

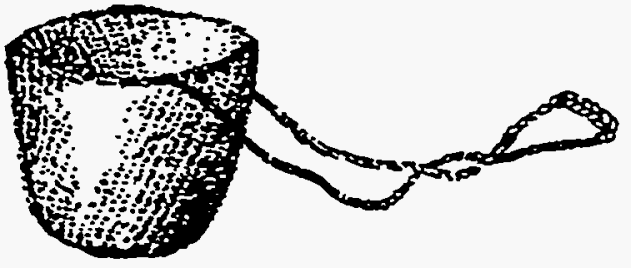


and the wars with the enemy, the Blackfeet. But I remember hearing stories about some Ksanka who were hiding in a dark cave and the Blackfeet grabbed their feet. They could tell by the make of the moccasins who it was. The Ksanka tribe of long ago had a fringed tab at the end of the heel. Later on all the Ksanka used a U-shaped tab. A long time ago the Flatheads used $a \mathrm{~V}$-shaped tab. In the winter we had moccasins with the hair inside to help keep our feet warm. Sometimes the men would stuff cut deer hair in their moccasins, too. My mother kept me in a baby board and I remember rocking my brother when he was little and was in one. I liked to unwrap him and take him out and he would stretch and move about. We could stand the baby board up on a teepee pole and the baby would sleep. About nine months was as long as we were kept in it because we then become too large for it. The baby boards kept our arms and legs straight. We could be moved about with our mother when she worked. The front of the board was decorated with beads. At night we were tied in cloth bags to keep us warm. When a baby is born the Ksanka knew right away what kind of a life he would have. If he cries a lot and real loud, it is a sign of a poor life. If he didn't cry, he would be a goodhumored person and good-hearted. Joe shot his first deer at the age of nine years with a twenty-two rifle he borrowed from his uncle. When he was young he often just lay down on the ground and slept out at night when it was warm. He went off to pick huckleberries and never worried about bears or anything. Joe's playthings were bow and arrows. The arrows were sharpened sticks with feathers, and he smoothed the wood with sharp rocks. The boys put clay on the end of sticks and swung them around and the clay would go flying off. They also would find oval rocks about the size of their hands and wind a string around them and pull to make the rock spin. Then with a stick with the string tied to it they would whip the rock to keep it spinning. The boys would sometimes have fights with their rocks hitting each other's rocks, and the rocks would often break. The boys peeled bark from branches and wound it to make a ball, and then they would shoot at it with their bows and arrows. One game was played using a hoop that was made with a stick bent into a circle. This was laced back and forth with buckskin strips like a snowshoe and in the center there was a small open place. This was called the heart. The boys would roll this hoop on the ground and take turns trying to hit the heart with darts or lances. They would bet on who could do it, and the winner got five sticks for hitting the heart, which was not an easy thing to do. The rule was that the one throwing had to stand on one spot without moving or he would lose his turn. For toys the girls had to use what they could find or make. Our favorite was a piece of rag. With this we could make rag dolls. I would have a man and $a$ woman and then would place them on forked sticks which I pretended were horses. Because rags were so scarce $I$ had to hide mine in a tree, or if someone noticed it and might take it, I buried it in the ground. Then I would mark the place with a stick so I could find it again. We children often had fights over rags. Another thing we liked to have was a bottle. These were very scarce but once in a while we would find one up on the hillside. Then we would smash it and sort the pieces and call them dollars and fifty-cent pieces, and so on. These would be our play money. We would bet each other we could win races. One that gave us great pleasure was holding one foot and hopping on the other to a certain place or rock. I was free as a bird playing around the hills and valleys of this area of Elmo, Hot Springs, Niarada and Lonepine. I was never afraid of anything. We even played with rattlesnakes with sticks, and made friends with them. They went their way and we went ours. Our folks told us they could kill a person. The wind and sun didn't burn my skin when I played out all the time when I was little. I was tough and didn't need a lot of clothes like the children do now. I went summer and winter in mostly just my skin, and I remember the warm fires we built with wood in our teepee. When I would come home at night after playing out all day there were times when my grandmother would just have a piece of bannock 
bread for me to eat. Sometimes I would have a dress my mother made out of a flour sack. When I was a little girl the people scattered all over to get food and to hunt, and then they would come back to the village. We had some elk, but deer meat was our main food. We used every bit of the meat and didn't waste anything. We even boiled the heads and ate all the parts of the animal. We cut the meat in long strips and dried it on wooden racks over the fire. This we would pound and sometimes mix with chokecherries that had been dried and also with bear grease which never got hard. It would keep a long time. We cut strips of bear fat and cooked it a long time. Then we hung the strips on tree branches and they were like butter. We ate this in small pieces because it was so rich. We ate when we were hungry and there were no special times of the day for eating. Joe would go out and hunt deer and killed a lot of them for our food. I let them cool for three days before I cut them up. I dried a lot of meat and even made hard lard for frying buckskin bread. I miss what we had then and nothing tastes as good anymore. Today we still like to dry some of our meat. We build a fire in a pit and lay some bedsprings on it. When the fresh meat has hung long enough to be firmed up, I slice it into strips and spread it out on the springs above the fire to roast. I turn the strips with a long fork until they are done. The dried meat is good to eat when it is pounded on a rock and it can be mixed with dried berries. I like to dry the muscles and cook them with beans to give them flavor. I used to heat a skillet with some lard and then fry the red kinnikinnick berries to eat. My favorite flower is the little sunflower. We picked them and sorted the arrowleaf stems out. They are the woman in the flower, and they are not juicy like the other stems which are the male. Sometimes I eat them now. When I was about three years old the government gave each person four yards of material down at Jocko. I was about six years old when my folks got some bacon, beans and flour from the government. The Indians gradually started to wear white man's clothing. One would get a pair of pants and then another one would, until they were all wearing them. The first log cabin I was in was in 1901 or 1902, and I remember it looked funny to me inside. It was built by an Indian named 'Elmo' and his wife. It was the first log cabin built where Elmo is now, and the town was named after him. This is one of the few places named now like it should be. The other places, mountains, lakes and rivers do not have the names the Indians gave them. I wish they had not torn Elmo's cabin down or cut the trees which grew on the shoreline all around Elmo. The Indians were moved out of the Kalispell area and some went west and some into Canada and we came down to the village at Dayton Creek. This was on the west side of the creek from the town now called Dayton, Montana, and a little north. In the Dayton Creek village all the houses were made of logs. My family and Joe's family lived in the log church which had an open stove made of rocks. When the smallpox and diphtheria came the government doctor came and burned all the buildings down and saved some of the people. I was taken to a doctor in Ravalli, but the rest of the family didn't catch it. We used to bury our dead in blankets when we couldn't find boards for

coffins. There were two cemeteries at Dayton and now our new one in Elmo. My sister Cecille and I were living in my grandmother's log house at Elmo when a man came looking for children to go to school at Jocko, which the government provided. I am glad my parents were not stupid and they let us go. At least my mother knew we would be getting three meals a day. The three that went from Dayton were Suzette Antiste, Mary Madeline Isaac and Helen Kallowat. There were no boys who went. We were the first Indian children from this area to go to Jocko to school, and the year was 1905. It was at school that I first braided my hair. On Sundays we all dressed alike. Since I didn't know a word of English, it was very hard at first, but 
I quickly learned the words to ask permission to leave the room. We went to school in a buggy and came home the same way. I didn't get back during the school year because it was so far, and for the same reason my folks weren't able to come and visit. My first Christmas in 1905 at school, I was the first little full-blooded Indian girl to ride in the train to Missoula. I was the teacher's pet, and I went with her to shop for Christmas. She was half paralyzed and I got fifty cents a week to comb her hair and help her dress, and I spent this for candy and peanuts to share with my friends. We had Christmas programs, and the teacher, Miss White, picked out parts for me, and we always had a Christmas tree in the recreation room. I went through the fifth grade and have always wished I had stayed longer, but I thought everything would always be the same and didn't see any reason for going on. My greatest wish is that my grandson, Tony, can complete college and get a good education and not drop out. It is only with a good education that he will not have to 'sit in my place.' Joe's father was chief of the village and held the religious services both morning and evening. The priest brought the Catholic religion to us from both the Mission at St. Ignatius and from Canada. A bell rang for the services both morning and evening and we all went. One man stood by the door of the church to see that no one went to sleep. There were whippings for digging the ground or chopping wood on Sunday, or for gossiping against our neighbors. The worst whipping was for flirting with another person's wife or husband. Years ago the Indian parents had authority over their married children and had their respect. It all changed after the whites took our religion and laws. It used to be a disgrace when a girl had no husband for her baby, and there wasn't the drinking and lawlessness that we have.

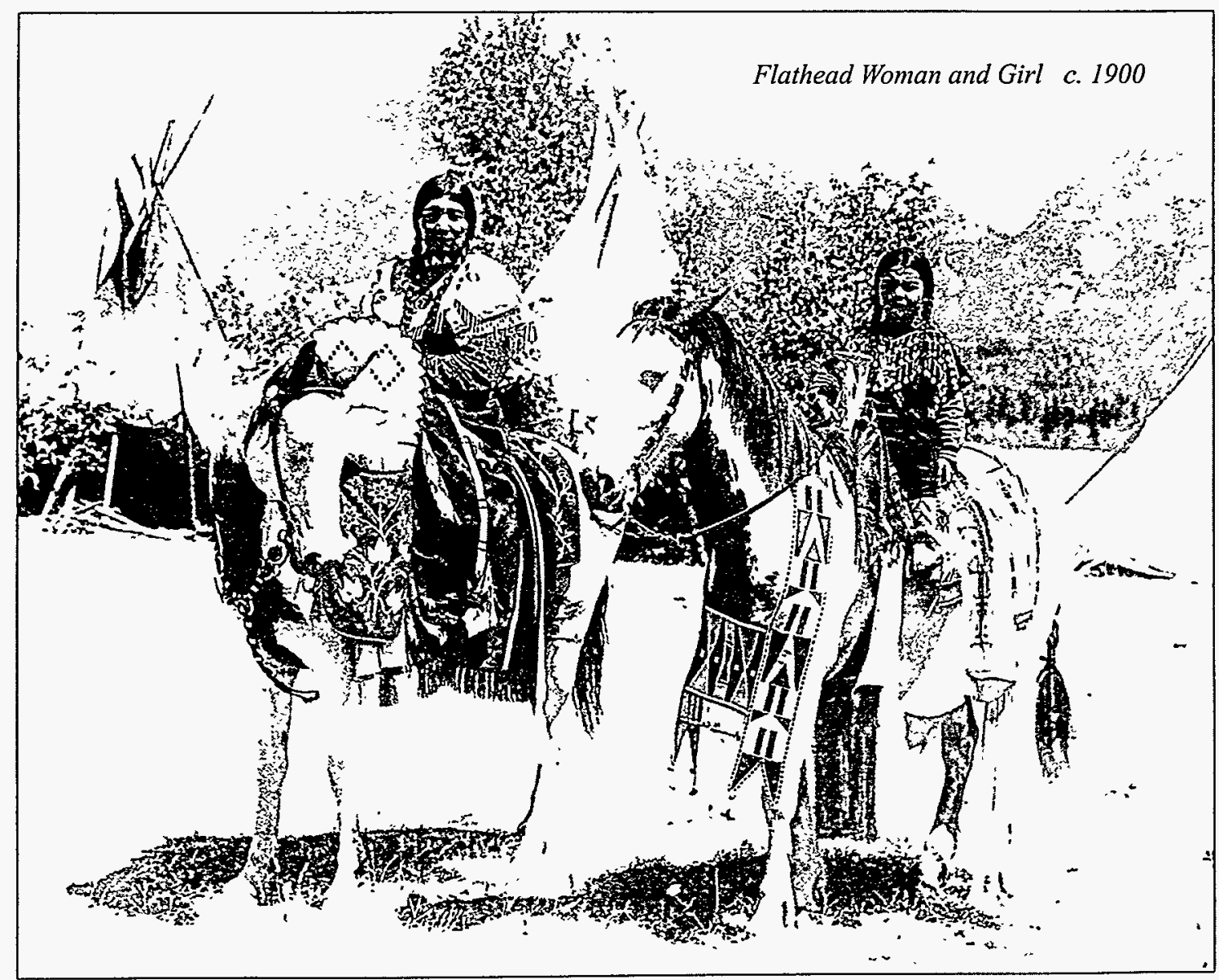




\section{The Reservation Today: Tribal Programs}

\section{NATURAL RESOURCES DEPARTMENT}

\section{DIVISION OF FISH, WILDLIFE, RECREATION, AND CONSERVATION}

Tribal interest and concern with regard to wildlife has existed as long as the individual tribes have existed. Prior to the arrival of Europeans, the tribes survived through utilization of their natural resources. Wildlife was one of the most important resources for the provision of food and clothing, tools, and the raw materials to fill a variety of basic needs. At that time, the impacts of man on the wildlife resources were quite limited.

Contemporary tribal wildlife management activities, in the form of several Tribal Council Resolutions, occurred during the 1930s. The tribal council established and sold the first tribal hunting and fishing permits and established fish and game regulations in 1936. In 1940, the first tribal fish and game commission was established by council action. The first tribal elk range was established in 1943, and tribal game wardens were hired that year. During the period of 1962-1977, the tribes received technical assistance on wildlife matters from the U.S. Fish and Wildlife Service. In 1977, The tribes hired a wildlife biologist. In May of 1978, the functions of the tribal wildlife biologist were transferred to the Bureau of Indian Affairs. In March of 1988, the tribes assumed wildlife management responsibilities under a PL 638 Contract. The wildlife management program is funded partially by federal contract funds, appropriations from the general tribal government, and by funds derived from recreation and bird hunting permits.

Each year, the tribal wildlife management program expends both funds and personnel time preparing and presenting public information and environmental programs. These presentations range from discussion of current wildlife management issues with sportspersons to environmental education presentations to local students and colleges and universities.

\section{DIVISION OF WATER}

The Division of Water has several areas of expertise: Water Management Program, which exists to quantify and evaluate the water resources of the Flathead Reservation; Safety of Dams Program, which ameliorates safety deficiencies in reservation dams; Water Rights and Water Administration, which organizes historic and present information for the administration of the reservation water resource; the Clark Fork Superfund, which monitors and prepares claims for the natural resources damages in the Clark Fork drainage; and the Geographic Information Systems group, which provides mapping and analysis of data for all tribal programs.

\section{DIVISION OF LANDS}

The Division of Lands employees professionals, technicians and administrative experts in the field of agricultural land use management, land use planning and management, management of Indian estates and other land use issues.

\section{DIVISION OF ENVIRONMENTAL PROTECTION}

The Division of Environmental Protection is charged with the development, implementation and execution of programs aimed at protection of the unique natural environment of the Flathead Reservation. The four programs comprising the Division are Air Quality, Water Quality, Shoreline Protection, and Solid/Hazardous Waste Management.

\section{TRIBAL FORESTRY}

The Flathead Indian Reservation is comprised of approximately 451,000 acres of forest land, of which about 322,000 acres are commercial forest. This forest land is managed as a whole, to include reforestation, fire management, insect and disease control, timber and economic opportunities for the tribes.

Forest managers are continually working with the general public, the tribal council, and other tribal resource professional to ensure that the reservation forests will meet the needs for timber, water, recreation, culture and wildlife far into the future.

The Tribal Forestry Department has established a professional and technical staff in preparing and presenting forest management issues and educational opportunities for the tribal population as well as the nonmember community.

\section{KICKING HORSE JOB CORPS CENTER}

The Confederated Salish and Kootenai Tribes of the Flathead Indian Reservation recognized the need to provide vocational training opportunities for Indian youth. A contract was initiated with the U.S. Department of Labor, which administers the Job Corps programs, to operate a center to accommodate 224 young Indian men and women, age 16 through 24 . The center has been in operation since 1970 .

\section{HOUSING AND COMMUNITY DEVELOPMENT}

The Salish and Kootenai Housing Authority was established by tribal council action in 1963 . Ordinance 38B established the Housing Authority as a separate tribal entity, managed by a six member board of commissioners that meets twice a month.

The mission of the Salish and Kootenai Housing Authority is to provide the highest quality, affordable housing to the people of the Flathead Reservation, utilizing all resources to ensure that services are provided in an efficient, economical and timely manner. 


\section{SHOSHONE-BANNOCK TRIBAL PROFILE}

\section{LOCATION AND LAND BASE}

The Fort Hall Indian Reservation is located in southeastern Idaho, with access from Interstate 15, ten miles north of Pocatello, Idaho. The counties of Bannock, Bingham, Caribou and Power lay within the boundaries. The cities of Blackfoot and Pocatello are on the northern and southern ends of the reservation, respectively. The reservation now consists of 544,000 acres of land, 96 percent of which is individually and tribally-owned.

\section{ENROLLED MEMBERS}

There are approximately 3,528 enrolled members in the tribes.

\section{LANGUAGE(s)}

dialects of the Shoshone family of languages

\section{TRIBAL GOVERNMENT}

The Shoshone-Bannock Reservation was established in 1867 by Executive Order of U.S. President Andrew Johnson. The tribes govern the Fort Hall Reservation and protect off-reservation rights and privileges. The Fort Hall Business Council is a sevenmember elected governing body, which legislates laws via resolution and ordinances. On behalf of the Shoshone-Bannock Tribes, the Council can also enter into agreements, memoranda of understanding and compacts with the State of Idaho, federal agencies, county and city governments.

\section{ECONOMIC BASE}

Tribal Enterprise: The Fort Hall Business Council oversees development and provides Reservation services through its various departments and offices. Services range from health programs, planning and zoning, and education to the judicial process and police protection. The personnel numbers approximately 280 , and mostly are tribal members. The tribal general fund moneys derive from assets on the reservation. The majority of general fund sources are from the leasing of agricultural lands. Right-of-way privileges also contribute to the general fund. In addition, the Fort Hall Business Council is the recipient of various grants from federal, state and private sources.

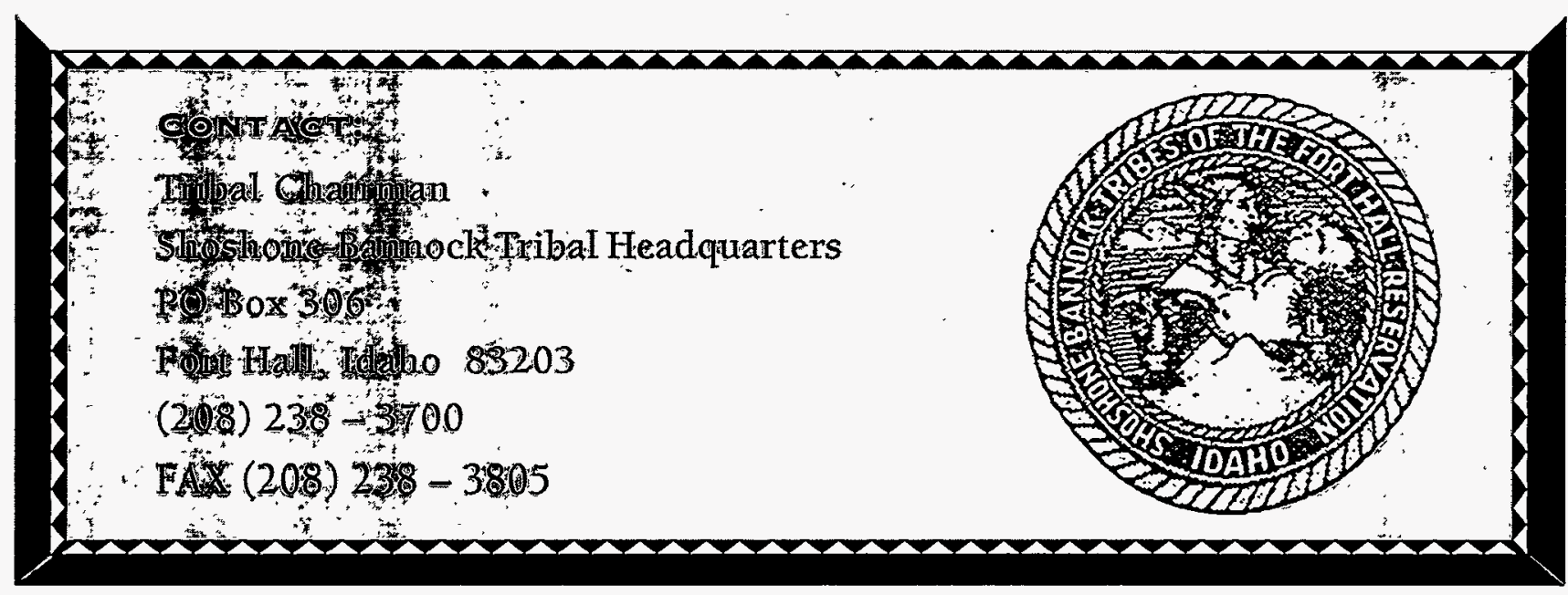




\section{TRIBAL BUDGET}

The tribal government operates on an estimated $\$ 4$ million a year from its own resources, and $\$ 9$ million

from grant and federal sources. 


\section{SHONSHONE BANNOCK}

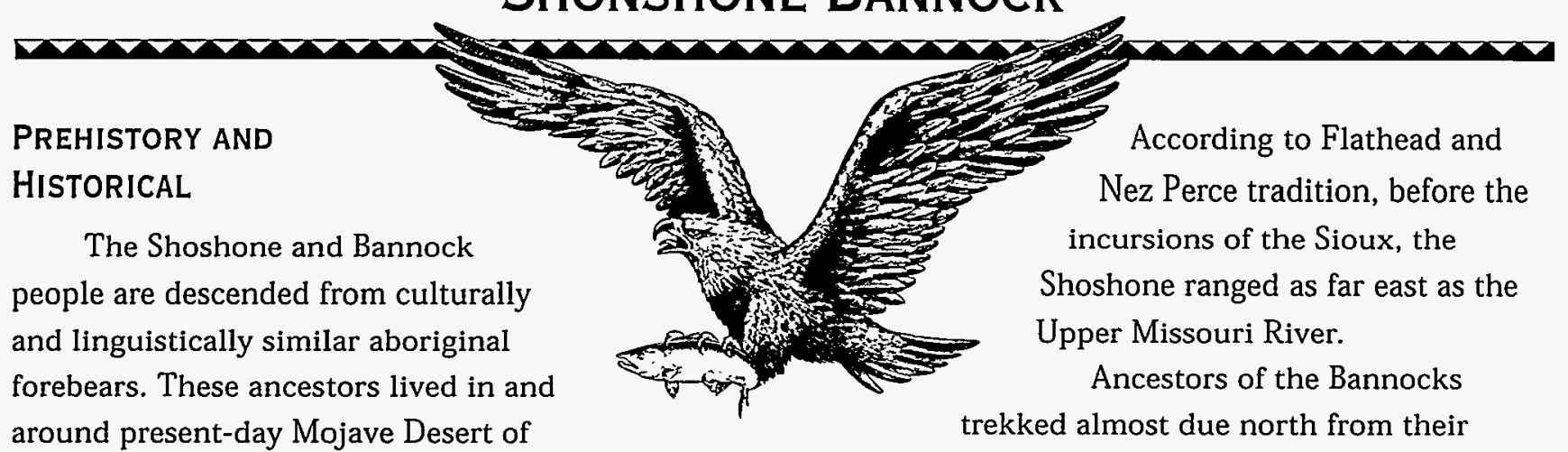

south-central California some four- to five-

thousand years before the present, then began

fanning out in response to a rapidly drying climate.

Ancestors of the Shoshone (or "Snake" Indians) radiated out in a north-northeasterly direction, arriving some 3,000 years-or-so ago in the Great Basin and the Great Plains. They continued to range this territory until the early 18 th century, when pressures from EuroAmericans drove the Siouan peoples westward from the Great Lakes, and these groups in turn began driving Shoshonean speakers westward into the Rocky Mountains of present-day Idaho.

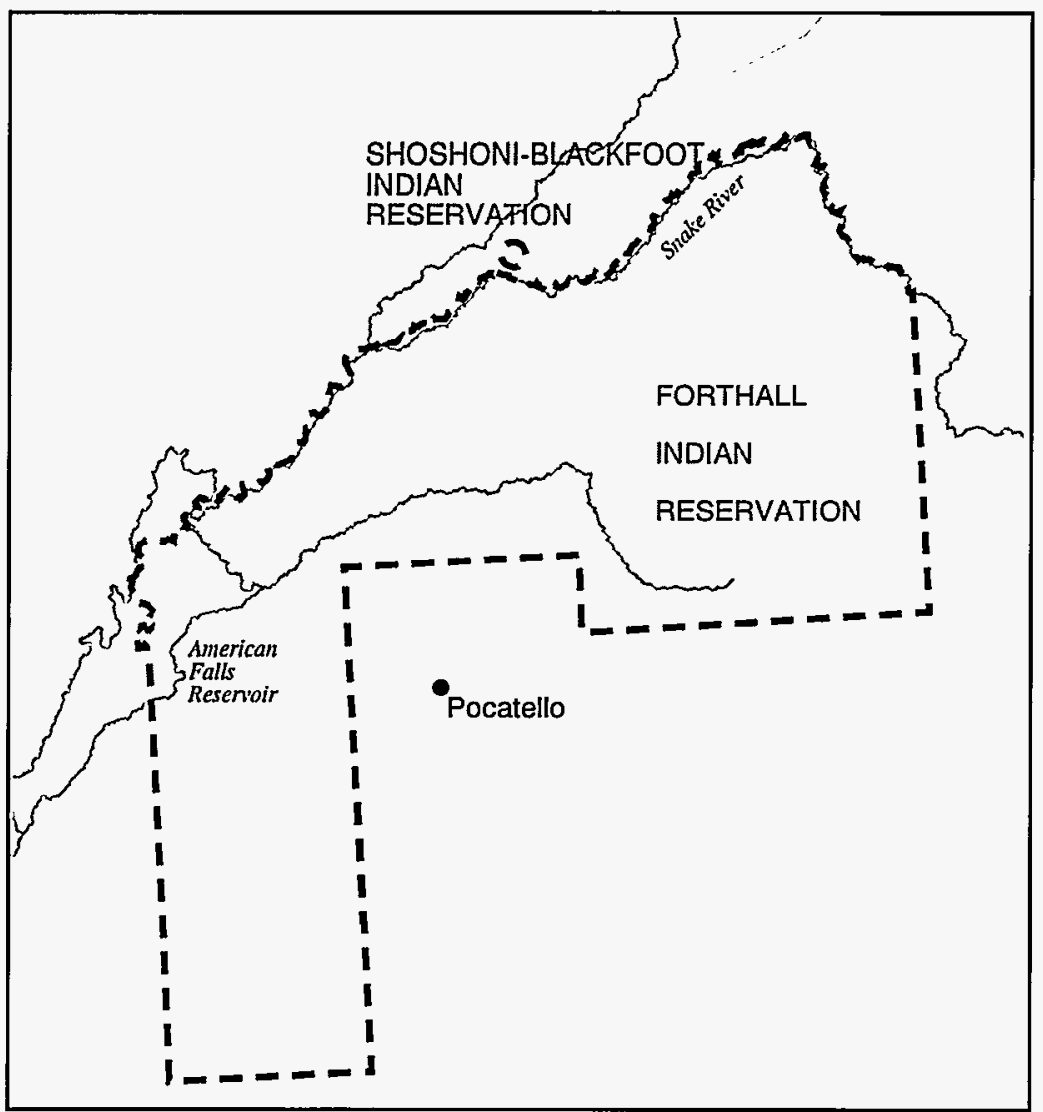

Mojave Desert homeland, establishing a cultural and linguistic stock known as Northern Paiute. Bands of Northern Paiute ranged from semi-arid northern Nevada and Utah to the prairies and intermountain areas of the Pacific Northwest.

Both the Shoshone- and the Paiute-speakers adapted quickly to their new aboriginal territories in the Great Basin, the Rocky Mountains, and the Great Plains, establishing lifeways that persisted for millennia, until the arrival of the horse. They ranged in small bands of two to five families in their respective territories, fishing the major rivers and their tributaries, hunting or snaring deer, antelope and mountain sheep, and gathering camas, bitterroot and bisquitroot bulbs, and berries and seeds, on the hillsides and in the river bottoms.

Widespread and scarce resources dictated that the people be able to gather subsistence and move on without delay, and so the small bands worked best. While the bands would cross paths during these seasonal rounds, they tended not to join together unless a task such as a rabbit or antelope drive required more people and organization. A particular band would seek out fish, game and vegetation where they were plentiful in a given year; but no band necessarily fished, hunted or gathered the same resource in the same place from year to year. As winter descended, these bands camped along the waterways that happened to be closest, and looked as if there were plentiful enough fish, game and firewood to supplement what they 
had preserved from their seasonal rounds. The locations of these winter camps tended to change from year to year. Also, the families in a particular band might change over time.

The result of this lifeway for both the Shoshone- and Paiute-speakers - a lifeway in which small bands ranged widely, then coalesced for visiting, feasting, game-playing, intermarriage and ceremony - was a portable, yet close-knit, culture.

In the early 1700s, the Northern Shoshone acquired horses through their ties with the Commanche, a Shoshone band that ranged throughout New Mexico who had acquired them from the Spanish. With the introduction of the horse, the bands of Northern Shoshone began moving farther out onto the Great Plains, searching for buffalo. While most Northern Paiutes continued their seasonal rounds on foot, some bands, who came to known as the Bannocks, took on horses, and traveled and hunted among the Shoshone.

Horses brought change to other elements of the Shoshone-Bannock culture. Buffalo became a more important part of the diet; and the increased cooperation required for a buffalo hunt led to more structured lines of authority. Where once a man with special talents for finding fish or game might take the lead in a band for the short time, now something closer to traditional chiefs began emerging to coordinate the buffalo hunt. The length of their tenure still depended on their skill, but rather than fading back into the band after a single task was complete, they might stay in leadership as long as they continued to produce results.

The size of Shoshone Bannock bands grew as did the complexity of their social organization and they ranged farther east. Bands rendezvoused and traded with Sioux agriculturists in present-day Nebraska, and with other horse-breeding tribes, such as the Crow.
Finally, non-agriculturist Siouan peoples from farther east began appearing in the late 18th century, driving many Plains Indians westward. Evidence suggests that by the time the Northern Shoshone retreated before the superior arms of the Sioux into the Rocky Mountains, their numbers had already been substantially reduced by major outbreaks of disease transmitted through the bands by contact with non-Indians.

The first recorded non-Indians to enter the Rocky Mountain aboriginal homeland of the Shoshone Bannock were members of the Lewis and Clark Expedition (1804-1806). In 1805, they stopped among the Lemhi Shoshone accompanied by Sacajawea, a Lemhi whom had been captured by Plains Indians before she joined the explorers. It was Sacajawea who persuaded her people, the Lemhi, to provide Lewis and Clark with horses.

Shortly after the appearance of Lewis and Clark, non-Indian trappers and traders began arriving in number. One of them, Andrew Henry, established an outpost on Henry's Fork in Shoshone-Bannock territory in 1810 . By 1818, the North West Company, the Hudson's Bay Company, the Canadian Northwest Company and the Rocky Mountain Fur Company were competing intensely for beaver and other furbearers throughout the Snake River basin and the northern Great Basin. While bands of the Shoshone-Bannock cooperated in the fur trade, they did not gather furs themselves. Rather, they provided horses and fish in return for firearms, in order to better defend themselves against their adversaries, the Blackfeet and Sioux.

In 1834, Nathaniel Wyeth founded the first Fort Hall, a thatched clay enclosure sixty feet square, constructed in a river bottom on the south bank of the Snake River, above the mouth of Portneuf. He stocked the "fort" with $\$ 3,000$ worth of trade-goods, hoping to capture the fur trade in the area. The marshy bottoms were home to a great deal of deer and waterfowl, provided good 


\section{Traditional Story: Coyote Frees the Game}

A long time ago the birds and animals were people and they all spoke the same language. They all understood each other. They all lived together in this one place and their leaders were Wolf and Coyote. In the place where they all lived there was a big mountain. The mountain had a tunnel to go through he mountain to a place where they found their food.

There was a gate on the tunnel that everyone had to close when they went to and from the place where they got their food. Wolf and Coyote told their people the gate had to be closed when they went to hunt and when they came back from hunting.

In this place where they hunted there were many animals and cranes that were not afraid of the people. The people could go through the tunnel and pick out which crane they wanted and go up to it and shoot it. That was because the cranes and animals were not afraid of the people. The people always did as their leaders had told them to. They always closed the gate when they went to and from the hunt.

Wolf and Coyote had told them that if they didn't close the gate all of the animals would get out and if the animals got out they would no longer be so easy to hunt because they would become afraid of the people and people wouldn't be able to get close to them.

All of these things happened before our earth became the way it is now.

Coyote's older brother Wolf sometimes called his little brother "Uncle." Coyote said that some day he would go hunting. When Wolf heard that Coyote was going hunting over there, he said to Coyote, "Coyote, you can go hunting over there, but when you go, close the gate when you go in. Pick out what you want and kill it and bring it out, but be sure to close the gate again when you get out. Be careful not to let all of those animals out of there."

But Coyote never minds his older brother Wolf. Coyote never believes what other people tell him. He always does as he pleases. When Coyote went hunting, he went to the gate. He closed the gate behind him and he walked and walked through the tunnel, he went out and went up onto a hill. There he sat, looking down on all the animals, the cranes and the elk and the deer. He looked down on all these and they were all food to him.

As Coyote sat and looked at the animals he thought to himself, "Why do the people want to kill these animals? These animals aren't sport. These animals don't move fast." And as Coyote sat and watched a little longer, he thought, "It isn't fair that the people should come here and kill these animals when they are like this. I wish that when I open the gate all these animals would run out and be on their own. And if the animals get out, I hope they aren't like they are here. They should be afraid of people." Maybe that's why these animals are like they are today. When you want to get them, you have to hunt for them and look and look and you can't get near them. So Coyote said, "I'll open the gate and these animals will get out. Then when people want to get the animals to eat, they will have to work for what they get."

Coyote opened the gate and all of the animals got out. When they reached the other side of the mountain they were afraid of people and they all went in different directions. And today, you can't get near these animals - the elk, the deer, the buffalo - because of what Coyote did wrong to his people by letting those animals out. After Coyote did that, when his people wanted food, they had to go hunt for it, search for it, and work to get what they wanted.

Coyote's people didn't like what he had done, but Coyote was satisfied. Coyote thought it was good that when you wanted something, you had to go work for it and look for it and search for it and when you finally got it, you earned it.

Ever since then, when the people wanted something they had to go look for it and to work for it and so when they got it, they were happy about it because they had earned it. This is something that really happened. Coyote really did these things a long time ago, and things really have been different ever since. 


\section{Spirituality}

Spiritual beliefs have always played a primary role in the life of the ShoshoneBannocks. Prayers and songs are a very important part of all the ceremonies conducted on the Reservation. In fact, spiritual beliefs are the very reason for the enduring nature of all tribes in the United States - not only the Shoshone-Bannocks.

There are numerous ways of worshipping by the tribal members, and not all believe in the traditional ways of worshipping. Some tribal members belong to the various denominations on the Reservation, including the Catholic, Methodist, Baptist, Episcopalian and the Church of the Latter-Day Saints.

However, the traditional ways of worshipping are still practiced on the Reservation, including the sweat lodge, the Sun Dance and the Native American Church. In all the beliefs, prayers are offered to the Creator or Great Spirit. Also, in many of the ceremonies the people set aside their personal differences to be unified in thought and prayer.

The Native American Church has been active on the Reservation since the 1900s. There are numerous members of the church, and throughout the year meetings are held by whomever may be the sponsor of a particular meeting.

The Sun Dance is considered to be a very important ceremony. Individuals dance for three nights and four days, and prayers are offered by the individuals as well as the Sun Dance leader to the Creator. The Sun Dance leader offers prayers for the entire tribe as well as for other races. Individuals may dance for their family members or for themselves. Individuals fast throughout the entire dance. They suffer so that their prayers may be answered. The dance is a prayer for health, prosperity, peace and happiness. forage for the Shoshone horses, and had traditionally been a rendezvous and winter camp for bands of Shoshone-Bannock. In the next several years they would serve as a focal point for Shoshone Bannock interaction with the nonIndians.

As long as the interaction centered around trade, the relationship between Indian and nonIndian remained cordial. However, Fort Hall also became a way station for travelers on the Oregon and California trails that cut through the homeland of the Shoshone-Bannock. In 1843, more than 1,000 people passed through Fort Hall. By 1845 , the number had increased to 3,000 people a year. The gold rush of 1849 brought more people into the area. The settlers that inevitably followed trappers, missionaries and miners were closing in on the Fort Hall Bottoms at a steady pace. By the 1860s, the buffalo that had been a central element in the Shoshone-Bannock culture had disappeared from the margins of their aboriginal homeland, and a permanent Mormon settlement had appeared in Bear Valley in southeastern Idaho.

Increasingly, Shoshone-Bannock bands encountered fences where they had once hunted and gathered. This led to tension, and the settlers' fear of the Indians, although unprovoked, was mounting. Idaho's territorial governor, Caleb Lyon, attempted to draw up treaties with the tribes that would contain them. Although many were negotiated, they were not ratified. Ultimately, U.S. President Andrew Johnson drew up an executive order in 1867, establishing the Fort Hall Reservation.

The Fort Bridger Treaty of 1868 confirmed the arrangement. On July 3,1868 , during treaty negotiations, Tahgee, leader of the Bannocks or Mixed Bands of Shoshones and Bannocks, declared on behalf of the people that, "I want the Portneuf Country and the Kamas Plains" as "a home for ourselves...on our grounds." General C.C. Augur, representing the United States, assured Tahgee 
that "the President would send someone to lay [out a Reservation], which shall include portions of the country they want," which Augur described as "their own country."

The government convinced the Bannocks to give up all their territories except for 1.8 million acres of their homelands, where they would be left in peace. The treaty stipulated that there would be separate reservations for the

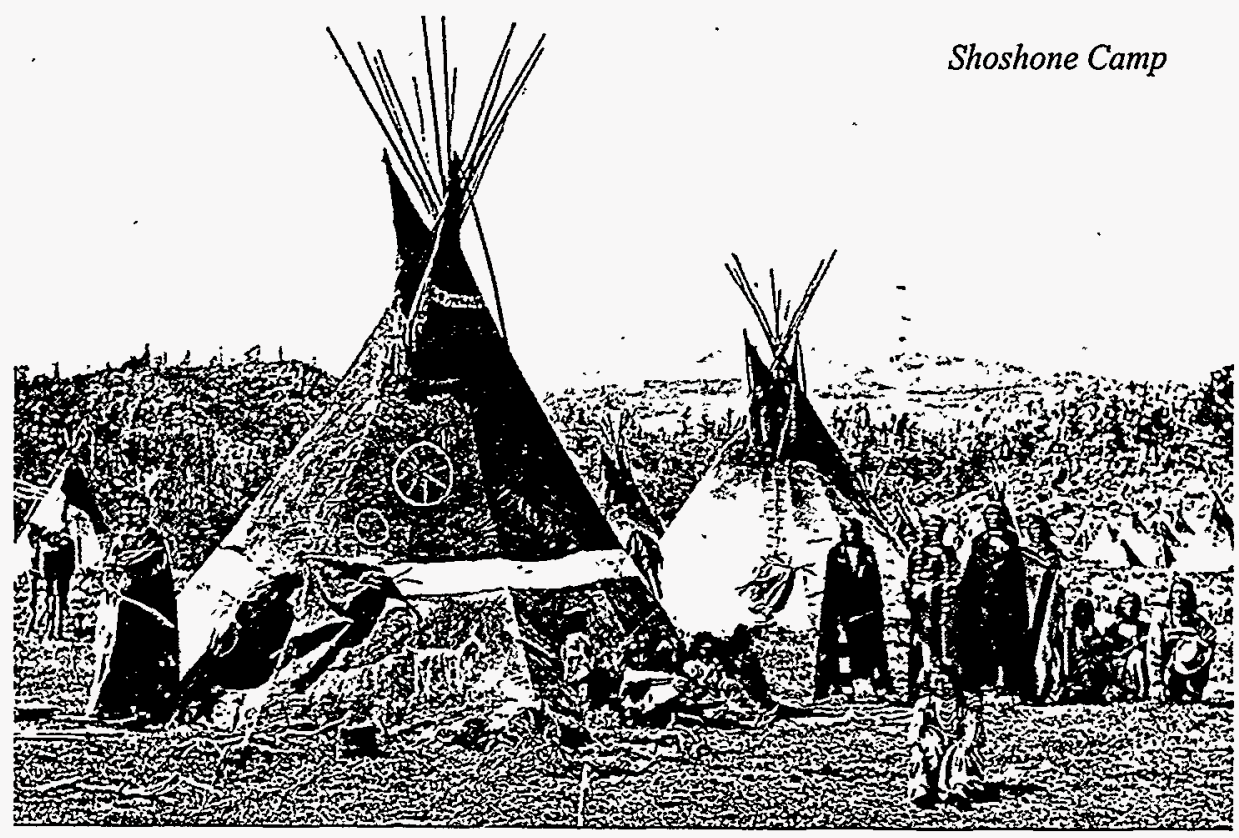
Shoshone and the Bannocks, but in the end, both remained at Fort Hall. When one looks at a map of the Reservation area, Tahgee's intention when he designated the Portneuf Country as a preferred homeland carved out of the tribes' vastly larger aboriginal territory becomes obvious. The United States and tribal leaders mutually understood that the Reservation locale was selected for two principal reasons: (1) it was an area traditionally used and occupied by the tribes since time immemorial; and (2) it contained and was bounded by extensive natural water systems central to the common goal of promoting tribal self-sufficiency. The Snake River, named for the Shoshone people, and the Blackfoot River, a key tributary originating off-Reservation, combined to form approximately 50 miles of the Reservation's northern boundary. The Portneuf River mainstem, approximately 100 miles in length, as well as most of its tributaries, were contained on-Reservation until 1900.

Still, despite Tahgee's intention, a surveying error during the 1872 survey of Reservation lands decreased them from 1.8 to 1.2 million. White encroachment into the area continued. Initially under the Treaty, the tribes were allowed to leave the Reservation in the summer to hunt and gather

camas on "the unoccupied" government lands, but white fears soon ended this right.

The Bannock Wars of 1878 were the final attempt of some independent hunters to fight for their traditional existence. When they were finally rounded up by the military, they were sent to Fort Hall. As Northern Shoshone throughout the region continued to be displaced, they too were sent to the eastern Idaho Reservation. Prevented from hunting, fishing and gathering in their usual and accustomed places, with numbers swelling on the Fort Hall site as more bands were sent there, hunger became a serious problem. Government rations were meager. Poverty and disease swept the Reservation.

In the late 1880s, the Shoshone-Bannocks felt the effects of the allotment process that divided Reservation lands into 160 -acre parcels for each adult, and 80 -acre parcels per child. After the land had been allotted among tribal members, the "surplus" was turned back to the government, in this case the growing city of Pocatello. The policy also allowed non-Indians to buy land within the Reservation resulting in checkerboard land ownership patterns today. The private ownership of land was to encourage Indian people to become 


\section{Traditional Plants and Remedies}

Before physicians and medicines were brought to the Shoshone and Bannock people when the Reservation was established in 1868, the people had their own remedies for different ailments using plants growing in the areas where the people camped or roamed.

Today there are very few people who know which plants are used for what ailments. A few remedies are still practiced in homes today and are being passed onto the younger people. Here are a few:

Sage/sagebrush is boiled and used as tea used for colds. When a person is congested, the sage tea causes the person to sweat and cough up the phlegm in the throat and chest. Though very bitter to the taste, it is effective.

Sage is also used to swab the throat when it is sore and has soothing effect. When the nose is plugged, a spray of young sage (Pagwiemp) can be used by sticking it in the nostrils. The aroma of the sage will clear the nasal passage so the person can breathe more easily. Sage is also used in the various religious ceremonies on the Reservation.

Wild Peppermint is used for diarrhea and upset stomachs, taken as a tea. It is also used for colic in babies.

Headaches are relieved by using the bark of a willow. Migraines have been known to be cured by a sharp implement, such as obsidian/flint, awl, glass, etc., which is used to puncture the skin near the hairline or forehead to allow the blood to flow. This was done to relieve pressure from the bad blood in the head causing the headache. This is known as "head poking." The Lemhi Shoshoni also used a root call PaSowu 'u, which grows along streams in the mountains. This was pounded and mixed with warm water and tied on the head with buckskin. If this failed, the inside of the nose was pierced with an awl to cause bleeding. Bloodletting/Bleeding was also done to alleviate tiredness or sluggishness. This was done by using a piece of obsidian or glass mounted on a stick and tapped with another stick on a vein to allow the blood (usually black and thick) to flow. The blood was them stemmed when the blood flowed freely and turned red

(Lemhi). For sore and inflamed eyes, the roots of the Pavohop (sweet sage) was pounded, mixed with warm water and the juice squeezed into the eyes. Scraping of the upper and lower eyelids was done by the use of a certain type of grass and obsidian.

A heated stone (and in more recent times a heated brick wrapped in a towel) are placed on the ailing spot to relieve the pain of cramps, or pain in the chest or heart.

Through old letters and documents we learn of how the relationship between doctors brought to the Reservation and the Indians was often strained. Along with the civilization, new diseases were introduced to the Indian people and only the medicines of the white man could cure them. Since the Indians could not understand what the doctor was trying to say, many often died and the Indians would not go to the doctor. Only by threats could they be forced to see the doctors.

As the younger people were educated and instructed on the matters of health and living in a civilized manner, the old people clung to the old ways of life and customs. The Indian doctors kept a low profile and though their services were often utilized, no one would admit they were seeing the Indian doctor because the government field nurse might hear about it and the Indian doctor would get in trouble. Often times, remedies that had worked in the past failed, and the medicine man was condemned by the Indian agent as being a bad influence on the people.

It is sad that much information on plants and remedies that were used are being lost because people no longer use them. The plants are being exterminated through lands being used for farming. Some of the weeds that are being destroyed were the medicines that were used for sickness and the people who knew how to use them are gone. Though we now have doctors' wonder drugs and modern technology, there are times when they fail and the old remedies are still effective.

Even now, modern doctors are testing some of the old remedies and finding there is some truth to them. In the last few years, physicians and specialists have been conferring with Indian doctors and medicine men from other tribes when an Indian patient is involved. This is a far cry from when Indian doctors and medicine men were ridiculed and discriminated against.

Submitted by Ms. Ardith Peyope Shoshone-Bannock Librarian 
farmers, but neither training nor equipment was provided to support the aim. Not surprisingly it failed.

\section{THE PRESENT}

\section{TRIBAL GOVERNMENT}

The tribal government of the ShoshoneBannock Tribes is more unique than most local and state governments. Initiated by the Fort Bridger Treaty, and refined in the wake of the Indian Reorganization Act of 1934, The ShoshoneBannock Tribes govern the Fort Hall Reservation and protect off-Reservation rights and privileges.

The Fort Hall Business Council is a sevenmember governing body that legislates laws via resolutions and ordinances. The Council can enter into agreements, memoranda of understanding and compacts with the State of Idaho, federal agencies, and county and city governments. The Business Council also composes the enterprise board, which oversees the various economic development projects on the Reservation.

The Shoshone-Bannock Tribes administer Reservation services through its various departments and programs. Services range from health programs, planning and zoning, and education, to the judicial process and policy protection. The personnel number approximately 280 staff members, most of who are tribal members. The tribal general fund moneys are derived from assets on the Reservation, with the majority coming from the leasing of agricultural lands. Right-of-way privileges also contribute to the general fund. The tribes also provide services through utilizing authorities under PL 93-638. Under this law, the tribes contract from the federal government, BIA and the Indian Health Service to provide services. In addition, the tribes are the recipient of various grants from the federal, state and private sources. Tribal government operates an estimated $\$ 4$ million a year from its own resources and $\$ 9$ million from grant and federal sources to perform governmental functions to the tribal membership.

The issues of jurisdiction are an everlasting topic among the tribes and local and state agencies. The tribes believe that, as a sovereign nation, they are entitled to all jurisdictional control. Ordinarily, the jurisdictional issue is resolved by clarifying the function of each party under a memorandum of understanding, or other instrument. Of course, some issues are unresolvable, and eventually go to the courts for interpretation.

By virtue of the Treaty of the ShoshoneBannock, the tribes have a direct relationship to the Congress of the United States. Members of the Fort Hall Business Council have testified numerous times before it. Most of these presentations have been in reference to new laws, federal policy, Indian rights or federal funding.

The Fort Hall Business Council also meets with State of Idaho legislators and the Indian Affairs Committee, established in 1982, to address issues that affect the Idaho tribes. Recently, the taxation of sales and cigarettes have come before the state legislature. Other issues include water uses and jurisdiction of public highways.

The following preamble summarizes the tribal government of the Shoshone-Bannock Tribes: "We, the Shoshone-Bannock Tribes of the Fort Hall Reservation, Idaho, in order to establish a more responsible organization, promote our general welfare, conserve and develop our lands and resources, and secure to ourselves and our posterity the power to exercise certain rights of self-government not inconsistent with federal and local laws, do ordain and establish this Constitution for the Shoshone-Bannock Tribes of the Fort Hall Reservation."

\section{TRIBAL ENTERPRISES}

Economic development for the tribes is a vital concern of the Business Council. To secure employment opportunities and revenue for tribal 
government services, the Business Council continues to consider and start up various economic ventures.

In 1978, the tribes at the recommendation of an economic development study done by Economic Development Administration (EDA) constructed the Trading Post grocery store located on the Fort Hall exit of I-15. This is a full-fledged supermarket, and over the past years provided employment to many tribal members.

In 1980, a grant was obtained from EDA for the construction and operation of the Clothes Horse and Teepee Gas \& Diesel. The Clothes Horse was at first a westernwear store, but over the years other lines of clothing have been added. The Indian Arts \& Crafts handled at the Clothes Horse have been a popular item with the many tourists who stop at the complex annually. The cigarettes and diesel have been a tremendous draw from the truckers on the interstate.

In 1985, the Oregon Trail Restaurant was completed. This phase of the commercial development is expected to draw additional business off the interstate and complement other existing businesses.

Also in 1985, a museum was constructed close to the commercial development, which houses historical artifacts and pictures of the Shoshone-Bannock Tribes. The museum also attracts tourists to the complex.

The tribes established a steel fabrication business in Pocatello in the fall of 1988. This business is eligible for Small Business

Administration minority status. The steel business has completed projects with Boeing in Auburn, Washington. The company has fabricated trusses for the Moscone Center in San Francisco, California, the Indian Health Service, and Nottsoo-Gah-nee Health Clinic here on the Fort Hall Reservation.

The summer of 1989 a branch office of the Pocatello Railroad Federal Credit Union opened on the Reservation at the Trading Post Complex.
The branch office offers full banking services including checking, savings and loans.

A gaming ordinance has been drafted and the Business Council has high-stakes bingo in operation on the Reservation. Construction for a bingo hall is underway next to the Trading Post Complex.

The Bannock Peak Truck Stop and Convenience Store opened the summer of 1989. The development provides needed employment for tribal members and provides revenue for the tribes.

The Business Council has recently purchased 550 acres of farmland. The land is now back into trust status, having been previously owned by a non-Indian.

\section{NATURAL RESOURCES}

Protection of the environment has always been extremely important to the ShoshoneBannock Tribes. The tribes are committed to providing a full range of sound natural resource management programs. Toward that end, the tribes have recently developed new programs in Pesticide and Air Quality Management designed to bring under control long-standing pollution problems. Other programs have been in existence since 1977.

There are three primary entities working in natural resource management and environmental protection. At the policy level is the Land Use Policy Commission, and at the staff level are the Land Use Department and the Fish and Wildlife Department.

The Land Use Policy Commission is a threemember elected body that administers the Land Use Policy Ordinance. The Commission's major responsibility is enforcing the Land Use Ordinance. In carrying out its responsibilities, the Commission relies on the procedures outlined in the Land Use Operative Policy Guidelines. These guidelines set forth specific procedures for reviewing and approving applications for building 
permits, special use permits, conditional use permits and sign permits. The policy guidelines recommend due process procedures for the Commission to follow when rendering a decision. The Commission deals with all Reservation land use, including enforcing the Ordinance on nonIndian fee lands.

The Land Use Department provides professional support to the Fort Hall Business Council and the Land Use Policy Commission on land use and environmental quality issues. There are six programs within the Department:

- The Air Quality Management Program monitors and regulates air pollution sources on the Reservation. The program recently developed an air quality code, and has been active in enforcement measures.

- The Environmental Program provides for the protection of both the Reservation environment, as well as off-reservation hunting and fishing treaty rights and the fish and wildlife habitat on which the exercise of those rights depends. Activities under this program range from preparing environmental assessments; grant proposals; detailed comment and analysis of state, federal and private project proposals; program planning; and when necessary, legal intervention in projects adversely affecting the environment.

- The Land Use Planning Program is preparing a comprehensive land use plan that will help shape the direction of growth on the Reservation for the next 50 years.

- The Pesticide Management Program certifies pesticide users on the Reservation, enforces pesticide regulations, investigates spills and violations and provides educational programs.

- The Surveying Program provides land survey services to the Reservation residents and coordinates with various entities concerned with land transaction activities.

- Water Quality administers wastewater construction projects, monitors ground and surface water quality, reviews proposals that may affect water quality on the reservation and administers Indian Health Service contracts to provide water and sewer service to tribal homeowners.

Fish and Wildlife provides professional management services for both on-reservation fish and wildlife resources, as well as the administration of off-reservation treaty hunting and fishing rights guaranteed under the Fort Bridger Treaty of 1868.

The Fisheries Program covers both onreservation fisheries management as well as offreservation fisheries programs. The Reservation Fisheries program encompasses fish stocking, harvest data collection, population surveys and habitat enhancement. The program also oversees the permit fishing system for non-members who fish for brown, cutthroat and rainbow trout in the Fort Hall Bottoms and American Falls Reservoir.

A significant portion of the program involves protecting habitat off-reservation for both resident and anadromous fish by participating with federal and state resource management agencies in project planning and review. Another major portion of the program is habitat enhancement funded by the Bonneville Power Administration. Several fisheries enhancement projects are underway currently in the Salmon River basin. The goal of this work is to restore anadromous fisheries into historical range. The tribes also participate in regional efforts to improve fish passage and survival through the Columbia and Snake River hydroelectric dams and in developing fair harvesting quotas.

The Wildlife Management Program administers hunting regulations for tribal members' big game hunting, both on-reservation as well as off-reservation treaty rights; as well as waterfowl and pheasant hunting permits for nonmembers. The program also conducts population surveys, habitat enhancement, transplanting endangered species and game stocking. 


\section{Shoshone-PaIUTE TRIBAL PROFILE}

\section{LOCATION AND LAND BASE}

The Duck Valley Reservation is an Executive Order Tribe (April, 1877) located between Mountain Home, Idaho and Elko, Nevada, on the IdahoNevada border. The reservation is composed of 289,820 total acres, of which 12,800 are under irrigation. Another 268,816 acres are designated for grazing, and an additional 8,204 acres for other purposes, such as water storage, commercial development and residential housing.

\section{TRIBAL ENROLLMENT}

1,729 enrolled members of the Shoshone and Paiute tribes

\section{LANGUAGE(s)}

dialects of the Shoshone family; dialects of the Paiute family

\section{TRIBAL GOVERNMENT}

1863 - Treaty with the western Shoshone

1866 - Northern Paiute from Oregon establish lodges at Duck Valley

1877 - Executive Order establishes the Duck Valley Reservation

1886 - Land added to the reservation for Paddy Cap Paiutes

1919 - Land added to protect water rights 1936 - The Shoshone-Paiute tribes develop and adopt a constitution and bylaws for Duck Valley Reservation

Currently, there is a six-person tribal council elected every two years on staggered terms. The tribal chairman is elected at large every three years.

The tribes are a self-governance tribe, as prescribed under Public Law 103-413, Title II, which transfers control to tribal government of funding and decision-making for federal programs, activities, functions and services. Under a self-governance compact, all governmental programs may be administered by the tribes by the year 2,000 . The tribes will then administer all federal programs with the exception of the federal government's trust responsibility.

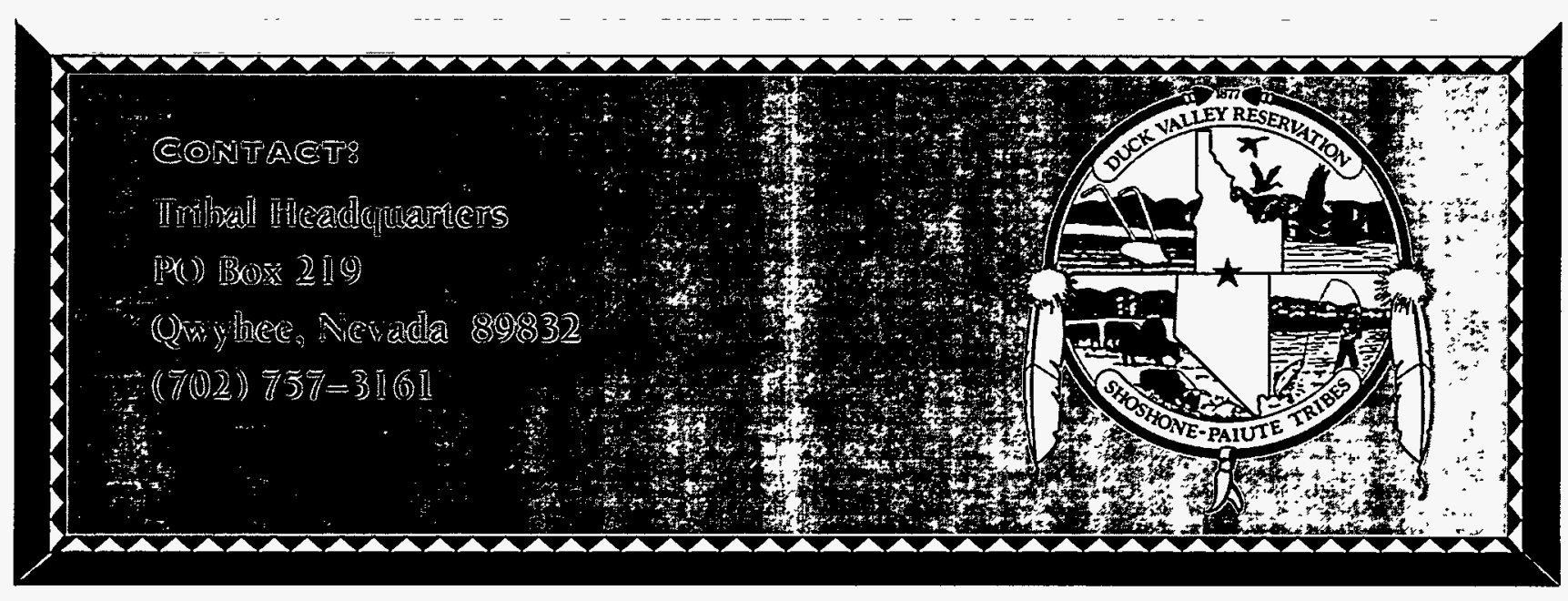


ECONOMIC BASE

The tribe itself is a major investor in the region with multimillion dollar operations. Some of the tribal businesses supporting economic diversification of the region are:

Colville Indian Precision Pine Sawmill

Three Tribal Grocery Stores

Inchelium Tribal Wood Treatment Plant

Colville Tribal Credit Union

Colville Tribal Bingo

Roosevelt Recreation Enterprise

Colville Tribal Loggings 


\section{SHOSHONE/PAIUTE}

\section{HISTORY}

The Owyhee River is a lifebearing artery that flows out of remote mountains just over the northern lip of the Great Basin and down through canyons until it a reaches wide, beautiful valley rimmed by volcanic debris and rocky plateaus. This is Duck Valley, the homeland of more than 1,200 Western Shoshone and Northern Paiute people.

To many who come into this area on the Idaho-Nevada border for the first time, the area looks rough and imposing, a semi-arid oasis in the high desert. To the Shoshone-Paiute of Duck Valley, their reservation - containing nearly 300,000 acres of land - is a garden, the last remnant of their once broad territory, a place where the people of the two tribes can preserve much of their own culture and past, while at the same time moving ahead to create agricultural and economic growth for the future. With the water from the Owyhee River, much of the land within the Duck Valley Reservation can be farmed and the Shoshone/Paiute people there can look forward to a long and healthy future.

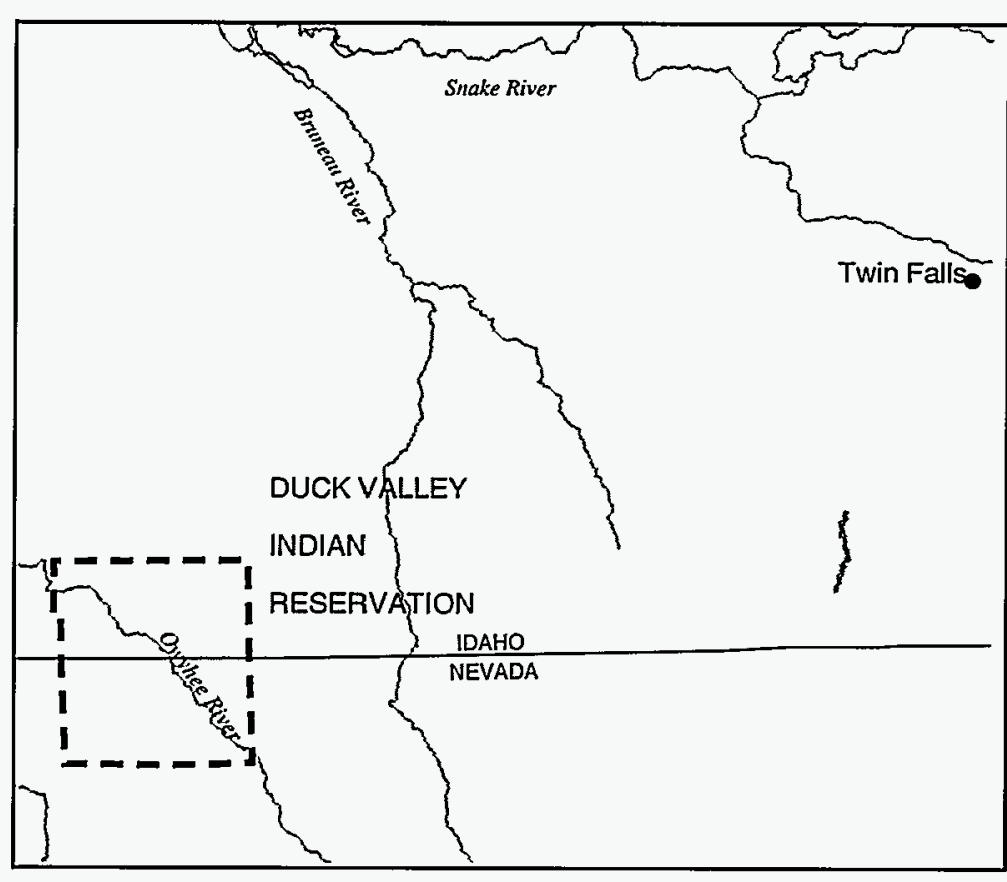

The Western Shoshone and the Northern Paiute have lived for hundreds of years in this part of what is now the western United States. Before the first Europeans invaded their territories, the Western Shoshone and Northern Paiutes lived mostly in bands or extended family groups, which usually did not exceed 500 members. They harvested grass seed, fished, hunted and made use of a very wide area of land each year, migrating to established seasonal camps as the hunting, fishing and gathering cycles progressed.

Probably, word of the first whites on the continent reached the Great Basin within a few years after Coronado's expedition in 1540, but the earliest stories would have been exotic and hardly believable until the 17 th century when tribes in the region obtained their first horses. The Western Shoshone and the Northern Paiute people of the Great Basin, however, did not make much use of the horse in their territory until the mid-19th century, probably because the horse was less a help to them than it was a competitor for the fragile and delicate arid grasslands (later, in the mid-19th century, parties of "white-knife" Shoshone were reported mounted during skirmishes and conflicts with the deluge of white immigrants).

The first Europeans in the ShoshonePaiute lands came from the south and possibly the west of the Great Basin. Spanish and later Mexican miners and slave traders penetrated the Great Basin from the south in the late 18th and early 19 th centuries. Some may have come over the Sierras from what is now California during the same period, but trappers in the late 1820 s and 1830 s were the first real invaders of Western Shoshone territory. Some of them were ruthless, some not quite so bad, but all exploited and 
seriously depleted the resources used by the Great Basin tribes. By the time of the great gold rush and the immigration of the 1840 s, the Indian people along the immigration routes had already suffered from severe damage done by the invaders to their environment and the sources of their native economy.

Even prior to major European settlements on the Western Shoshone and Northern Paiute ranges, many of the tribal people had seen their native plants and animals almost wiped out, so that when whites began to describe the condition of Indians in the area in the 1860s, they noted people who were often incredibly poor. In order to survive, many of the Indian peoples in the region began to work for whites at low wages around the towns mines, ranches and farms. A series of treaties in the 1850 s and 1860 s were meant to secure a basic existence for the Western Shoshone, but the federal government still today has not lived up to its end of all the bargains it made at that time. By 1877 , it was clear to some of the Indian leaders that if some Indian land were not saved for the Indians, the people's way of life might not endure.

The leaders of Western Shoshone bands were often given the title of "Captain" by white officials, as a symbol of their authority over their bands. Captain Sam, the leader of one such band, in the 1870s, spoke with a federal Indian agent in Nevada, telling him that the traditional territory of his band had good potential for farming, as well as fish, game and timber. He went on to suggest to the agent that it be protected for his people, and set aside as a reservation where Western Shoshone could live far from the areas which at that time were frequented by whites.

\section{THE RESERVATION}

On April 16, 1877, the

President of the United States signed an executive order setting aside the Duck Valley Reservation, and thus answering the request of Captain Sam for a permanent place in which his people could live and learn to ranch and farm. Within the next few years a number of bands of Western Shoshone and some Northern Paiutes moved to the New Duck Valley Reservation and began to take up farming and ranching there.

Captain Sam's band of over five hundred people had traditionally lived in the territory along the Owyhee River, which feeds eventually into the Snake River, and along the Humboldt drainage in the Great Basin, with most of their activity ranging throughout what is now northeastern Nevada. Another band leader, Captain Buck, had been a signer of the 1863 Ruby Valley Treaty, so his band evidently came from a portion of what is now central or eastern Nevada. Still another band, which was nominally led by Captain George, had already settled along the Nevada/Utah border, and its members were working for whites at the time of the establishment of the Duck Valley Reservation, but with that establishment they also moved to the reserve. Other band leaders whose people moved to Duck Valley included Captain Charley, George Dick and Big Dick, the latter a Northern Paiute leader whose traditional territory was in southern Oregon and southwestern Idaho, and whose band was said to have intermarried with Western Shoshone groups.

Some of the Western Shoshone bands relocated from a short-lived reservation along the Humboldt, called Carlin Farms. A number of Western Shoshone had located there and had been attempting to learn farming techniques, but whites appropriated so much of the water in the vicinity that farming became impossible and the 
experiment turned into a debacle. Before long, there were a thousand Indians living at Duck Valley, planting crops, digging ditches, building brush "wickiups" and log cabins, diverting water for irrigation and doing all without the aid of any white instructors. It was clear that the people wanted to learn to farm in the white man's way, and were willing to work hard. The promised help from the government failed to materialize, and in fact, all too often the government agents impeded agricultural progress.

In the mid-1880s, the Western Shoshone at Duck Valley were joined by a group of Northern Paiutes. This group was under the leader Paddy Cap, and they moved to Duck Valley in 1886 following their release from where they had been held in captivity at the Yakama Reservation. In the late 1870s, Paddy Cap's band joined in the Bannock War against whites in southern Idaho, a revolt prompted when whites preempted important lands in the Camas Prairie, an area used by Western Shoshone and Northern Paiutes in south central Idaho. Paddy Cap's band was imprisoned at the Yakama Reservation following the revolt and held until arrangements could be made to locate its members at Duck Valley. As a result of the arrival of Paddy Cap's band at Duck Valley, an addition was made to the reservation in 1886 , increasing the size of the reserve on the Idaho side.

Between 1880 and the early 1900 s, other small bands of Northern Paiutes and Western Shoshone drifted into Duck Valley, or were forcibly located there by United States authorities. Some of Chief Leggin's band eventually moved to Duck Valley from their territory in the Fort McDermott, Camp Harney and Quinn River areas. Western Shoshone groups from the North Fork and Jarbidge mountain areas, from the areas around Deeth, Wells, Starr Valley and the Sutoya Mountains also moved onto the Duck Valley Reservation, some as late as the 1900 s. The small bands that lived in the rugged and isolated mountains of the Jarbidge area were some of the last to move onto the reservation.

In the early days of the reservation there were some attempts by the government to remove the Duck Valley people to the reservation at Fort Hall in eastern Idaho, but these efforts were resisted, not only by the Indian people, but by some of their white neighbors, who predicted that soon the Indians would be self-supporting. Impassioned pleas by the Duck Valley leaders, including Captain Sam, Captain George and Captain Buck, helped convince authorities not to remove the people from Duck Valley.

\section{EARLY RESERVATION AGRICULTURE}

From the beginning, the Duck Valley Reservation was thought of by both Indians and whites as a place where the Shoshone and Paiutes could attain self-sufficiency by farming and ranching. From the very beginning, also, it was known that in this high, semi-arid desert valley, crops would not grow without irrigation. Western Shoshone had been engaged in irrigation work for white settlers long before the establishment of the Duck Valley Reservation. Prior to 1869, they had begun gaining experience in constructing canals and working to irrigate hay crops. By 1878 , the year after the establishment of the reservation, and before any substantial government help had been provided to them, more than 1,000 Shoshone were engaged in building a viable ranching/farming economy.

At the outset of the reservation, the Western Shoshone, although they had not been provided help, began irrigating the fertile valley lands by themselves. Within five years after the establishment of the reserve, the Indians had constructed a small diversion dam where the Owyhee River enters the reservation. Canals were constructed to carry water to tracts of land in the valley. By the time that government agents arrived to try to assist the Duck Valley people in their agricultural efforts, the Indians were already 
planting and tending fields, had built canals and a diversion dam, and were progressing in their attempts to achieve agricultural self-sufficiency. In the 1880 s, they built a flour mill and expanded their fields and irrigation ditches. The government established boarding schools on the reservation during the same decade. But it was clear to the government officials from the outset that more was required to guarantee the Duck Valley farmers water for their fields throughout the short growing season. In 1889, the reservation agent suggested to his superiors that the Owyhee River should be dammed in order to impound enough water to guarantee a year-round supply. The earliest records of homesteaders in the area appear in 1890 , so it was possible that the agent could see that there might be a future problem for the Indians. In fact, as water was diverted from the Owyhee River upstream from the reservation, the supply to the reservation was already being reduced, even during the wettest part of the year. If a dam were built, and water impounded, it would protected the Indians' water in two ways: from the annual seasonal cycle and from the encroachments of non-Indians.

In 1890 , another request for a dam was made by the agent, and in 1891, a survey was made of a potential dam site. During the ' 90 s, a famous Yavapai Indian, Carlos Montezuma, a whiteeducated doctor, established health care on the reservation, but on the whole, almost all the economic advances made by the tribes in this period were accomplished on their own. Requests for a dam were ignored through most of the decade. By 1899, an estimate of the cost of constructing a reservoir had been submitted to officials in the Interior Department. More nonIndians were diverting water from the Owyhee River for their own purposes between 1890 and 1900; but by the turn of the century the Indians still had enough water for the irrigation works which they had already been able to develop.
However, there was never enough water available to allot the lands on the reservation, as had been intended under the 1887 Dawes Allotment Act.

As the 20th century progressed, more and more white diversions of Duck Valley water took place, and just as the tribes began to find success in agriculture, their water supply began to dwindle. By 1909, it was reported that the tribes had thousands of horses and only 500 cattle. Government agents attempted to encourage Indians to raise more cattle and fewer horses throughout the early reservation period, but the people were slow to accept the proposal because the accumulation of horses had come to represent wealth and prestige to the people. In 1909, the tribes had 6,000 acres under irrigation, and a year later the government acknowledged that as things then stood, without a dam to impound water the tribes required all the water then flowing in the Owyhee River. In that same year, the government made a small addition to the reservation in order to protect the water in a tributary that belonged to the tribes upstream from the reservation and to prevent further water encroachments in that area.

\section{THE NEED FOR A DAM}

As the number of whites competing for tribal water increased, the problems of the ShoshonePaiutes of Duck Valley mounted. In 1911, three Indians traveled from the reservation to Washington, D.C., to urge the construction of a dam that would allow them a regular flow of water and access to their legal water rights. No action was taken, and again in 1915, two other Indians went to Washington for the same purpose. The persistent pleas of the Indians apparently resulted in some small actions by the government, but it was not enough. In 1914 and 1915, gauging stations were installed along the Owyhee, and in 1915 the Bureau of Reclamation acknowledged Duck Valley's prior rights to Owyhee River water. During the latter year it was also recommended 


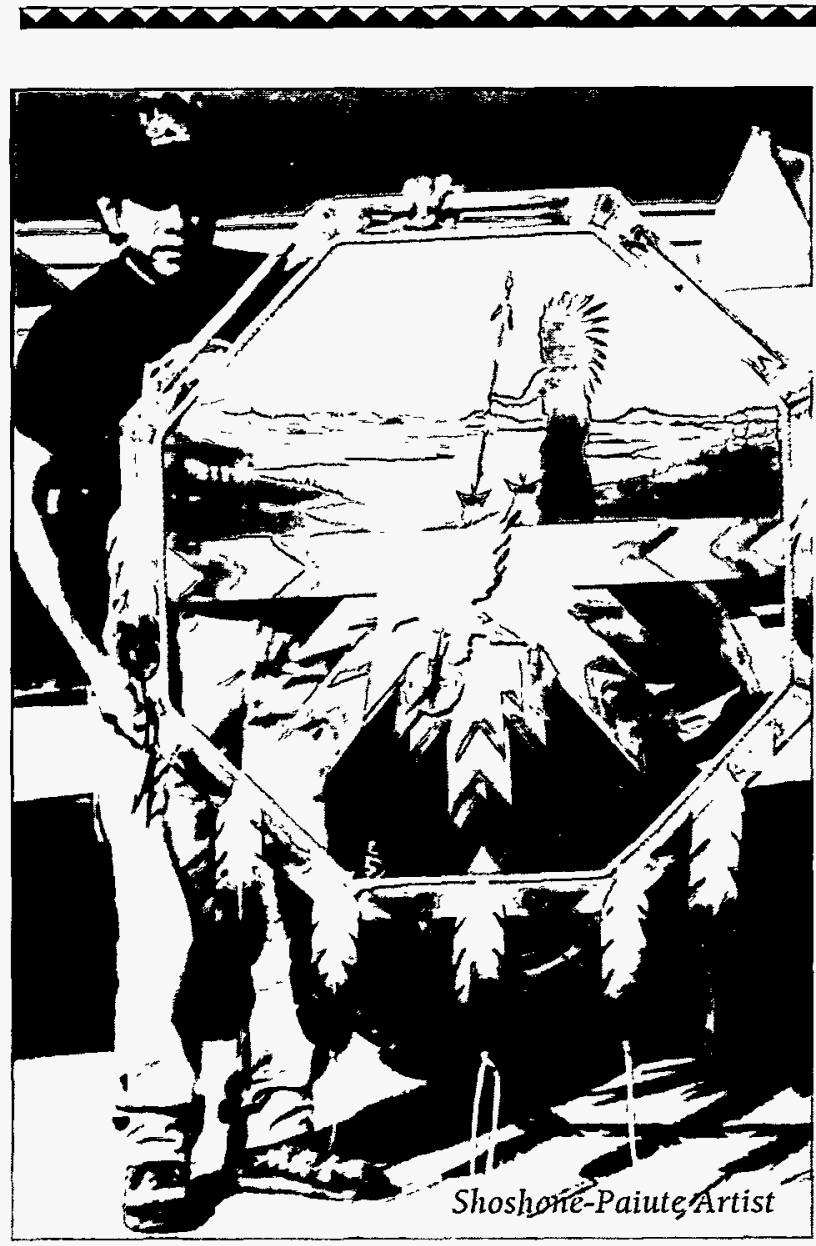

that lands that might be used for a reservoir be set aside indefinitely in order to prevent further encroachment in areas that would be necessary in the future for a Shoshone-Paiute reservoir. Again, the following year, a special agent made the same recommendation for a land withdrawal. In 1917, the General Land Office made and gave approval to the same request, but still no action was taken and the Indian people at Duck Valley continued to suffer for lack of access to their water.

A two-year drought that lasted from 1918 through 1919 prompted the tribes to petition the government once more to build a reservoir to ensure their access to, and use, of their water. The government did not act, and as a result the tribes suffered seriously. No action was taken between 1919 and 1924, when a supervising engineer reported that Duck Valley's problems were becoming more and more difficult "as more and more water is appropriated on these streams both above and below the reservation." He went on to recommend the adjudication of the water, but again no action was taken.

Tribal elders today recall the period on the reservation as being a time when the land looked like a dust bowl, when once prime horse and cattle herds shrank and when the people suffered without enough water to irrigate their fields. In 1925, the government again acknowledged Duck Valley's prior rights to the Owyhee River's water. In 1928, Commissioner of Indian Affairs, Charles H. Burke, requested adjudication of Duck Valley rights and estimated that 75,000 acre-feet of impounded water would be necessary to satisfy the legal needs of the tribes and of those who encroached on Owyhee River water.

Encroachments on the upper Blue Creek between 1909 and 1928 had so limited the water available to the Duck Valley people that in 1928 the tribes abandoned their developments on reservation land along that tributary. Special Assistant to the Attorney General A.G. Ethelbert Ward, in a letter of April 17, 1928, "refers to the absence of any action of Congress otherwise disposing of the water rights reserved by the government for this reservation....and gives it as his opinion the reservation priorities date respectively from April 16, 1877, and May 4, 1886, and that storage water may be claimed under such priorities."

\section{WILDHORSE RESERVOIR}

Although there continued to be some government opposition to the expenditure of funds to rectify the Duck Valley situation, serious work finally got started in 1929 to plan for the building of a dam to impound Owyhee River water. The work continued through 1930 and 1931 , and culminated in an extensive report by Louis Cramton in 1932 on the rights of ShoshonePaiutes of Duck Valley and the necessity of constructing a dam. Cramton had as a young man received his law degree from the University of 
Michigan and had gone on to be a small-town newspaper publisher and an eighteen-year Michigan congressman before being defeated in 1930. In 1931, Secretary of the Interior Ray Lyman Wilbur had appointed him a special attorney. If anyone in the administration had expected Cramton to use his legal expertise to circumvent the needs of the Indian, they would be mistaken, for Cramton early in his report ("Report of Facts With Relation to Water Rights of the Indians of the Western Shoshone [Duck Valley] Indian Reservation, Especially in Relation to the Owyhee Reclamation Project") stated:

....these Indians have kept faith with the Government and the Government cannot afford to permit their rights to be encroached upon or to itself encroach upon them....

Cramton itemized the long history of requests for a dam on the Owyhee River, and emphasized their validity, but added that "Indians cannot live upon promises and upon hope." $\mathrm{He}$ suggested that one site for a dam was the preferable one - the Wildhorse site, and said that it would provide sufficient water to irrigate the Indian lands, so long as no further leases or permits to whites were issued which would encroach further on the Owyhee water. He praised the people of the reservation, saying, "This Indian community is notable in the ambition and selfreliance of many of its members..." who were at that time irrigating nearly 8,000 acres with what water they had left. Acknowledging that there had been clear encroachment on the water belonging to the Shoshone-Paiutes of Duck Valley, Cramton urged protection of the remaining water.

Downstream, whites were requesting another dam to provide for a new non-Indian reclamation development. To this Cramton said:

Even if it should be true that there is a "much better prospect of economic success" on the Owyhee than in Duck Valley, that does not justify taking property rights in water from our Indian wards to give to their more advanced neighbors. That can only be justified on the theory that from him that hath not, it shall be taken to the uttermost.

The special attorney for the Interior Department noted that the Duck Valley people needed at that time a minimum of nearly 50,000 acre-feet of water, and made a point of emphasizing the applicability of the Winters Doctrine as it pertained to the Owyhee River and Duck Valley. He went on to point out that the proposed reservoir would allow whites to continue their uses and the Indians to claim their legal rights to Owyhee River water. He said:

The Executive Order of July 1, 1910, increasing the reservation, upon the representation of the Secretary of the Interior that such action was necessary for protection of reservoir sites; the action of the Interior Department January 11, 1917; the well-known Kietz-Johnson Survey of 1915-1916; the petition of the Indian tribal council July 28, 1919; the frequent discussion of storage and protection of the water rights for these Indians in appropriation hearings from November 21, 1924 to date; and the endorsement by the Indian Service, Interior Department, Budget Officer and Congress of appropriation for engineering and other studies leading to the development of storage; all of these are notice of the governmental purpose to develop storage and utilize the water of this Indian reservation as may be feasible. Failure to do so now would be abandonment by the trustee of rights belonging to the beneficiary of the trust.

In the early 1930s, Duck Valley ranchers were forced to sell some of their cattle and horses because they could not raise enough hay to feed them through the winter, but Cramton's report finally swayed the authorities. In 1936, the Bureau of Reclamation, acting in concert with, and under direction from, the Bureau of Indian Affairs, engaged in buying lands, obtaining title to lands, and if necessary condemning lands for the reservoir site. Between 1936 and 1937, sixty years 
after the establishment of the Duck Valley reserve, Wildhorse Reservoir was built, originally impounding 32,000 acre-feet of water, and providing enough water to irrigate 13,000 acres of Duck Valley's land.

Since, 1937, Wildhorse Reservoir has always been operated for the benefit of the ShoshonePaiute tribes of the Duck Valley, providing irrigation water for their agricultural projects. Through the use of tribal water, impounded by the reservoir, the tribes by the 1960 s had 11,000 acres of subjugated agricultural land, and long-range plans called for the agricultural development of thousands more acres to put the Shoshone-Paiutes on a course toward self-determination.

About 1965, it was discovered that Wildhorse Reservoir had been deteriorating over the years and was in an unsafe condition. In a two-year project, begun in 1967 and completed in 1969, a new dam was constructed at the Wildhorse site. The new dam not only made the reservoir secure and safe, but provided for the impoundment of additional water. Wildhorse Reservoir can now hold a total of 72,000 acre-feet of water. This additional water storage was impounded to provide additional water for the reservation and guarantee a minimum flow even during a drought year.

Despite the clear history of Wildhorse Reservoir - that it was built for the express purpose of providing water for the tribes and has always been managed for that purpose - a serious controversy has developed over the future use of the impounded waters in the reservoir. As access to this remote part of the country became easier, sportsmen began to visit Wildhorse, and fishing, boating and tourism became popular on the lake. By the early 1970 s, several special interest groups in Nevada began lobbying, attempting to preempt the rights of the Shoshone-Paiutes and acquire control of the reservoir so that it could be used entirely for the benefit of tourism and recreation, and so that the flow of irrigation water out of the reservoir could be restricted.

In October of 1975, a Bureau of Indian Affairs report summarized the findings of an indepth study of legal water rights of the Duck Valley Shoshone-Paiutes. The report stated that the tribes had "first right to approximately 90,000 acre-feet of water to be used in the irrigation season" from the Owyhee River, with priorities. "Should the irrigable acreage be increased on the Reservation," the report continued, "and two consecutive dry years occur, sufficient water would not be available to satisfy both the diversions upstream of the Reservation and those of the Reservation. In this case, the Reservation right would be the first right to all the waters flowing in the Owyhee as required for irrigation."

At this writing, the controversy remains unresolved. The tribes have tried to negotiate with officials in Nevada in an attempt to arrive at a compromise solution. They have offered to give up a number of their rights associated with Wildhorse to satisfy the demands of non-Indians, but so far a solution has not been achieved. The tribes have few financial resources and cannot generate a great deal of political clout, while the lobbying of nonIndians has been intense. Today, the tribes have more than 13,000 acres of subjugated agricultural land, and plans for the development of more farmland. Without control of their irrigation water, the tribes face an uncertain future on the Duck Valley Indian Reservation. Without water the farms and ranches of the people, which have been built over more than a century of hard work, will be in great jeopardy, and without the economic base provided by ranching and farming, the tribes will be almost totally dependent on government support. With the water, the tribes continue to work towards economic selfsufficiency. It is of critical importance to the future of the tribes that their water rights remain secure. 


\section{THE FUTURE}

The extensive use of anadromous fish, including salmon and steelhead, during the early period and prehistoric period is well-documented and is supported by all the available evidence.

The recollection of some of the oldest people living at Duck Valley confirm not only the onreservation fishing activities and the existence of an economy based on salmon and steelhead on the reservation proper, but also that many fish were taken from other places. We know that our ancestors fished in well-established locations on the Snake River.

The following is an excerpt in quote from $\mathrm{Dr}$. Sven Liljeblad from The Indians of Idaho, December 1990:

"In the oral traditions of the Shoshoni Indians there is much mention made of journeys to a yearly gathering - an inter-tribal rendezvous in the country where the Boise, Payette, and Weiser rivers empty into the Snake. Before any white man had as yet visited the region, Indian people from far and near congregated at these waters early in the summer in order to celebrate the opening of the fishing season and, above all, in order to trade..." The Shoshoni, Nez Perce, Paiute, Umatilla and Cayuse joined in "....peaceful and busy trading, alternated with ceremonial dancing, gambling and merrymaking. This half-legendary fair is said to have lasted as unbroken tradition in connection with fishing and camas harvesting until sometime in the early 1860s, when the white prospectors moved in and when (at the same time) the Columbia River salmon suddenly ceased to run in the Boise River."

As for the fish on-reservation, this is documented by virtually all of the historic records, including the well-known statement made by Levi
Gheen. He reported that the salmon in the East Fork of the Owyhee River where the reservation is now located was "inexhaustible." This letter report was prepared immediately prior to the setting aside of the Duck Valley Reservation and provides incontrovertible evidence that the reservation was chosen in part because of the abundance of anadromous fish.

Fishing continues to play an important part in the economy of the Duck Valley Reservation. This is evident in the establishment of the Sheep Creek and Mountain View Reservoirs. They are both well-known fisheries throughout the West.

This year, the tribes are embarking on the development of another reservoir called Billy Shaw, which calls for the lake to be a trophy fishery. The tribes are also doing an extensive habitat enhancement of the two existing reservoirs.

Redband Trout still exists in the mountains streams and the tribes are going to enhance habitat on those streams in order to bring this species back to historic levels.

In cooperation with our sister tribes, the Shoshone-Bannock of Fort Hall, Idaho, and the Burns Paiute Tribe of Oregon, the Shoshone-Paiute of Duck Valley are entering into a Motherhood Document for the establishment of the Compact of the Upper Snake River tribes. In the policy statement, "The Compact will work to ensure the protection, enhancement, and restoration of the rights created by statutes and reserved by Treaties through inherent and Aboriginal Rights, which concern all cultural and natural resources and activities." The Shoshone-Paiute and the Shoshone-Bannock tribes are also acquiring a joint fish hatchery, which will provide for their respective fisheries. 
There exists on the Duck Valley Reservation a beautiful wetlands area that has many species of rare and beautiful birds. There is the possibility that a bass fishery can be established on this site. This will add another opportunity as the tribes embark on a path of economic growth. The loss of the anadromous fisheries affected the economy of the tribes at the turn of the 20th century. In keeping with the tradition of our culture, we plan on building economic self-sufficiency once again around a healthy fishery. 


\section{SPOKANE TRIBAL PROFILE}

\section{LOCATION AND LAND BASE}

The Spokane Indian Reservation is located in northeastern Washington state, comprising most of the southern portion of Stevens County. The reservation is bounded on the west by the Columbia River, on the south by the Spokane River and on the east by Chamokane Creek. The northern boundary is marked by the 48th parallel of latitude. The total area within the reservation boundaries is 157,370 acres. 100,221 acres are held in tribal trust; 29,614 acres are in allotments; 21,683 are deeded fee lands; and 3,085 are government lands.

\section{TRIBAL ENROLLMENT}

Approximately 2,200

\section{Native Language(s)}

dialects of the Salish family of languages

\section{TRIBAL GOVERNMENT}

\section{ECONOMIC BASE}

Commercial developments on the Spokane Reservation are pursued and promoted through the Spokane Tribal Economic Development and Planning Office, and then managed by the Spokane Tribal Business Council and administrative offices. At present, the primary Spokane tribal enterprises are the Wellpinit Trading Post, the Eagle Feather Sawmill, the Two Rivers Resort and a bingo hall in Chewelah, Washington. Independent enterprises operated by tribal members include the Speelya gas station and convenience store near Wellpinit, Kieffer's store and gas station near the Fort Spokane bridge, Pappy's Corner Grocery, McCoy's Marina, West End Snack 'n Chat, Rajewski's Insurance, Shred-Away, TJ's Store, Lil' Chief's Casino and the Double Eagle Casino in Chewelah.

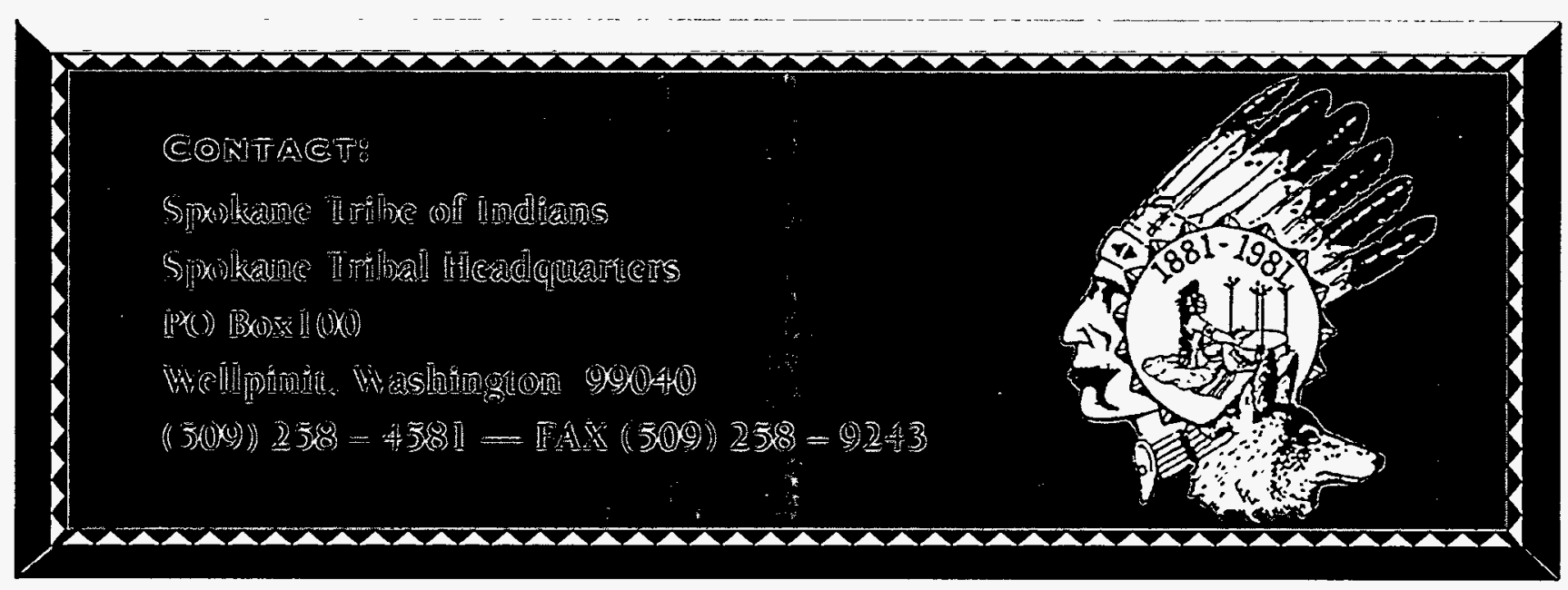




\section{SPOKANE}

\section{MAIN NARRATIVE}

\section{INTEGRATED RESOURCE} MANAGEMENT

A comprehensive planning process for the Spokane Indian Reservation began in the 1960s, long before the process was called the Integrated Resource Management Plan (IRMP). Several concerned members of the Spokane tribal community circulated a questionnaire in 1967 and began to consider factors that should be included in a management strategy for the reservation as a whole.

Through the 1970s, uranium mining brought sudden prosperity, and the planning process faltered during the temporary economic boom brought by the mines. In the 1980 s, as the mines closed, the tribe reverted to a greater dependence on timber sales for economic support. This reliance on the forest as the tribe's primary source of income and sustenance resurrected the old concerns about appropriate planning and careful management of reservation lands. A questionnaire circulated around 1985 revealed the community's desires that other forest values be preserved while timber harvest continued.

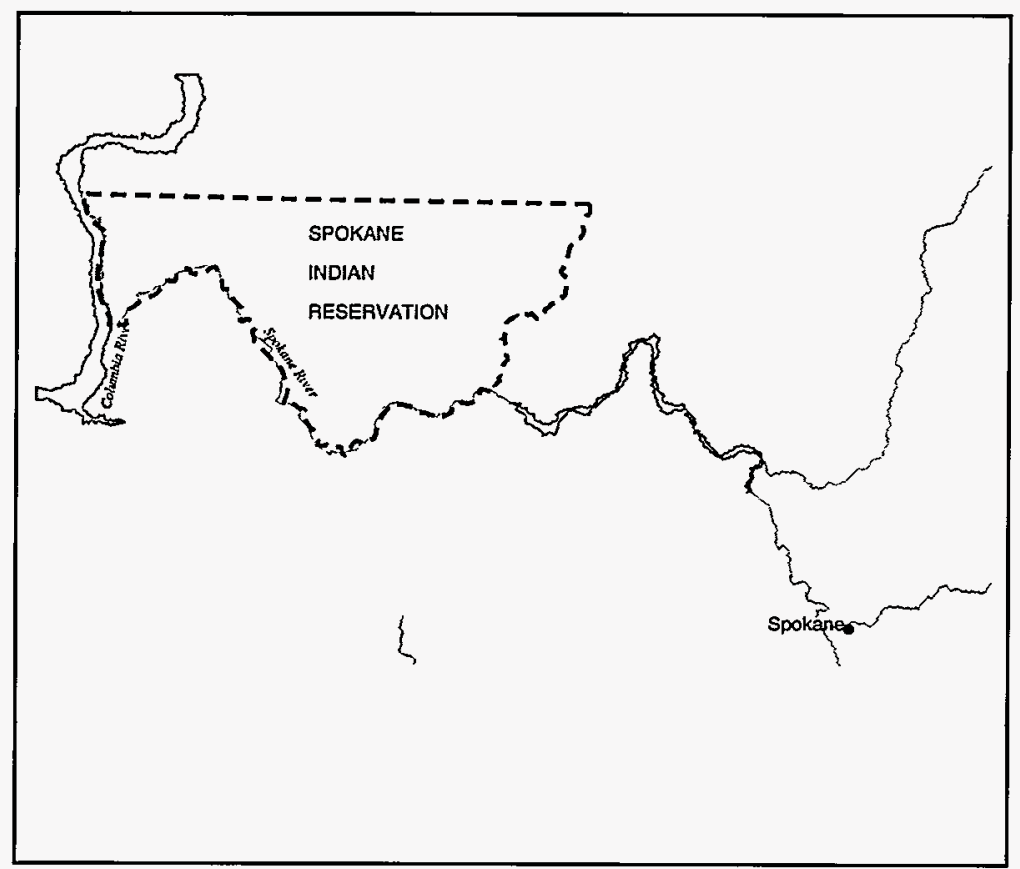

\section{MANAGEMENT OF Cultural RESOURCES}

The Spokane Tribe's most valuable resources are bound within the tribal culture. These resources include the Spokane dialect of the Salish language, oral history, traditional family and social relationships, behavioral norms, dances, songs, ceremonies and spirituality. A common thread through all elements of tribal culture is the Mother Earth and all that the earth provides to humans and all other living things.

Cultural sites are protected through an internal process involving review of all sites where timber harvest of development is proposed. The Cultural Resources Protection Officer responsible for these site reviews is a tribal member appointed to this role by the tribal general council. Vegetation and other tangible resources of cultural importance are protected through this process, which ensures that cultural values are considered when the interdisciplinary team reviews proposed timber sales and developments.

Intangible cultural resources (such as language, ceremonies and traditional community activities) are preserved and promoted by the tribal culture office, the tribal business council and individual 
tribal members who actively practice and teach the traditional ways.

\section{MANAGEMENT OF LAND RESOURCES}

Real estate transactions are determined by the tribal council and carried out both within the tribal business offices and in the BIA's Realty Office. Such transactions include leases; land purchases; transfers of property to and from trust status; and land assignments.

The tribe is prioritizing lands for purchase according to key criteria, and has plans to strengthen tribal management capacity and jurisdiction over consolidated landholdings.

\section{Management of SoIls AND Minerals}

Impacts on soils are key consideration when timber sales are planned, reviewed and carried out during logging operations. Other land use activities - such as housing and commercial development, utility installations, and roads - aim to be compatible with soil characteristics for loadbearing capacity and soil stability. The IRMP interdisciplinary team will be more involved in reviewing such activities, becoming more alert to potential compaction, pollutant percolation and other soil conditions connected to land uses.

\section{MANAGEMENT OF WATER RESOURCES}

Water resources management is currently a cooperative function among tribal, BIA, and Indian Health Service programs:

The Spokane Tribal Water Resources Data Collection and Monitoring projects include sampling surface waters and wells, establishing baseline information, and monitoring trends in water quality, quantity and flows.

The Spokane Tribal Laboratory provides analytical services for water samples taken from wells, public drinking water systems and surface waters.

The U.S. Geological Survey and a hydrogeologist at Eastern Washington University have conducted field studies of groundwater resources, attempting to map and quantify the aquifers and basin water budgets.

The BIA Spokane Agency's Environmental Coordinator and Land Operations staff assist the tribe in maintaining tribal monitoring and sampling programs. The BIA also responds to situations involving actual and potential contamination or harm to water resources.

The Indian Health Service (IHS) has funded capital outlays for public drinking water systems for the Spokane Reservation's residential communities. The IHS is working with the tribe to transfer ownership and management of these public water systems to the tribe.

The Spokane Tribal Legal Counsel's Office, working with the tribal business and general councils, has negotiated an agreement with the Washington Water Power for the tribe to assume ownership and management authority over the Spokane River system. Tribal water resource programs are expected to grow, adding more tribal employee training, more field monitoring and laboratory analyses, and a greater information base for tribal water management.

\section{MANAGEMENT OF FOREST RESOURCES}

Primary responsibility for forest management rests with the combined tribal/BIA Forestry Program. This program performs functions in silviculture, inventory and inventory analysis, harvest planning, presale reconnaissance, timber marking and timber sales oversight. Forest development functions include timber stand improvement (thinning and cull tree felling) and planting. The fire management program carries out duties in prescribed burning and response to wildfires.

As of fiscal year 1995, the Spokane Agency Branch of Forestry employed almost forty yearround and seasonal employees in the forestry and fire management programs. The forestry program also supports training opportunities for full-time 
staff, seasonal workers and tribal members who are students in high school and college.

\section{MANAgEMENT OF RANGE AND AgRICULTURAL RESOURCES}

The BIA Spokane Agency Land Operations office is the federal management entity for range and agriculture. Land operations issues grazing permits, monitors farm and pasture leases, and responds to issues concerning livestock, nontimber vegetation and wetlands, The tribal range program under a BIA contract, handles fencing, development of springs and livestock watering places, noxious weed control and other functions related to livestock grazing.

Most farm leases are negotiated directly between the farmer and the tribal business council.

\section{MANAGEMENT OF FISH AND WILDLIFE RESOURCES}

The tribal wildlife committee addresses policy issues such as hunting seasons and bag limits, incorporating advice from wildlife biologists. Members of the tribal wildlife committee also comment on wildlife protection needs in timber sales and other land uses, and assist with wildlife population studies.

Enforcement of tribal hunting and fishing policies is carried out by the tribal conservation officer, tribal park rangers, BIA law enforcement officers, and game wardens appointed and deputized by the tribal business council. Tribal fisheries and wildlife technical staff function under several different projects funded by federal agencies and the tribe, including:

The fish and wildlife program director administers programs and staff, participates in meetings regarding jurisdiction and resource management, reviews timber sales and other proposed land uses for impacts on wildlife, and makes wildlife habitat management recommendations, and is coordinating the Blue Creek Winter Range Project.

The wildlife habitat biologist implements the Wildlife Management Plan, collects data on habitat and population conditions, and assists other staff with technical input.

The tribal timber, fish and wildlife coordinator reviews and makes recommendations on timber sales and other land uses as they might impact natural resources.

The Lake Roosevelt Monitoring and Data Collection Project studies impacts on fisheries resources of the Columbia River hydroelectric systems operations and the Grand Coulee Dam.

The tribal Kokanee Hatchery raises and releases stocks of resident fish into Lake Roosevelt in mitigation for fisheries lost with the installation of Grand Coulee Dam.

Upper Columbia United Tribes (UCUT), a consortium of the Spokane, Kalispel, Coeur d'Alene and Kootenai Tribes, is involved in efforts to mitigate for damages to fisheries and wildlife from Columbia River hydroelectric systems operations.

\section{MANAGEMENT OF PARKS AND RECREATION}

The tribal parks and recreation program manages recreation areas along the shores of the Spokane and Columbia rivers (impounded as Lake Roosevelt, the reservoir behind the Grand Coulee Dam). Shoreline management responsibilities for the parks program include development and maintenance of recreation areas, access roads and boat launches; collection of camping and fishing permit fees; and enforcement of camping and boating rules and regulations.

This program also manages the recreational vehicle park at the Two Rivers Resort. Through reinvestment of income from camping and RV park fees, the parks program will be able to expand its functions to include development and maintenance of recreation areas in the interior of the reservation, for use by tribal members. 


\section{MANAGEMENT OF COMMERCIAL DEVELOPMENT}

Commercial developments on the Spokane Reservation are pursued and promoted through the Spokane Tribal Economic Development and Planning Office, and then managed by the Spokane Tribal Business Council and administrative offices.

At present, the primary Spokane tribal enterprises are the Wellpinit Trading Post, the Eagle Feather Sawmill, the Two Rivers Resort and a bingo hall in Chewelah, Washington.

Independent enterprises operated by tribal members include the Speelya gas station and convenience store near Wellpinit, Kieffer's store and gas station near the Fort Spokane bridge, Pappy's Corner Grocery, McCoy's Marina, West End Snack 'n Chat, Rajewski's Insurance, ShredAway, TJ's Store, Lil' Chief's Casino and the Double Eagle Casino in Chewelah.

\section{MANAGEMENT OF HOUSING AREAS}

The tribal housing commission sets policy direction, and the tribal housing authority handles day-to-day operations of tribal rental and homebuyer programs. The tribal business council, with assistance through BIA Realty, handles homesite leases and realty transactions related to housing.

With the formalization of the IRMP interdisciplinary teams, new housing sites will be reviewed and carefully considered on the basis of recommendations from multiple perspectives about the appropriate placement of new homes.

\section{MANAGEMENT OF UTILITIES/SERVICES}

Utility services on the Spokane Reservation include:

- Roads managed by the BIA, Spokane Agency, Branch of Roads.

- Public drinking water, public wastewater treatment and solid waste disposal services provided by the tribal Public Works
Department, with funding from Indian Health Service, BIA, and the tribe.

- Electric connections provided through Washington Water Power Company, and telephone connections provided through U.S. West Communications.

Other public services provided on the reservation include:

- Law enforcement services provided by the BIA.

- Emergency medical services provided by the tribal ambulance department.

- Clinical medical services provided by the Indian Health Service.

\section{INTANGIBLE VALUES}

Numerous resources considered in the Integrated Resources Management Plan have intangible value that exceeds any material appraisal. Cultural resources are the most striking example of resources with value that cannot be quantified in dollars. Other such resources include the value of having clean and sufficient water and air, the value of diversity among creatures dwelling on the reservation, and the value of beautiful vistas, untarnished by evidence of human intrusion.

These intangible values contribute to an ambiance of peaceful community on the Spokane Reservation. The land, water and air support and challenge the reservation's residents.

Tolerance, forgiveness and openness to new ideas are intangible values of human resources on this reservation. Decisions made by human beings about how natural resources will be managed raise issues common to every tribal member who relies on this reservation as a homeland. The ability of the decision-makers to work as a team, considering each person's contribution, will make the IRMP process effective. Such a value is difficult to measure, but very real. 


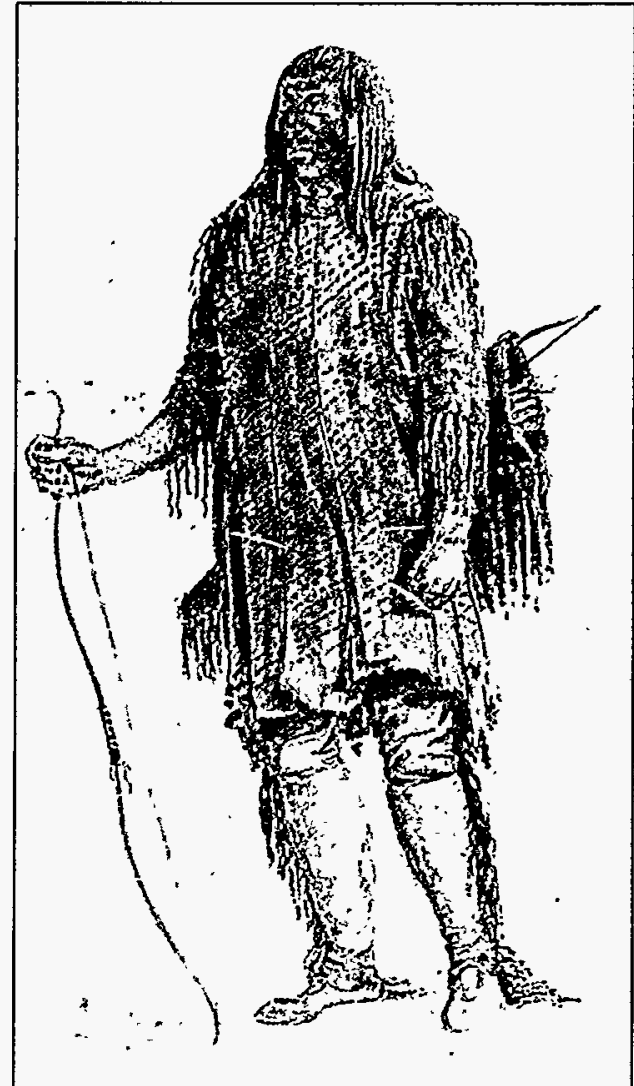

Tum-se-ne-ho, or The Man without Blood, a Spokane chief, by Paul Kane (1847). He carries a combined bow case and quiver as well as a second bow, a custom common among the Spokane.

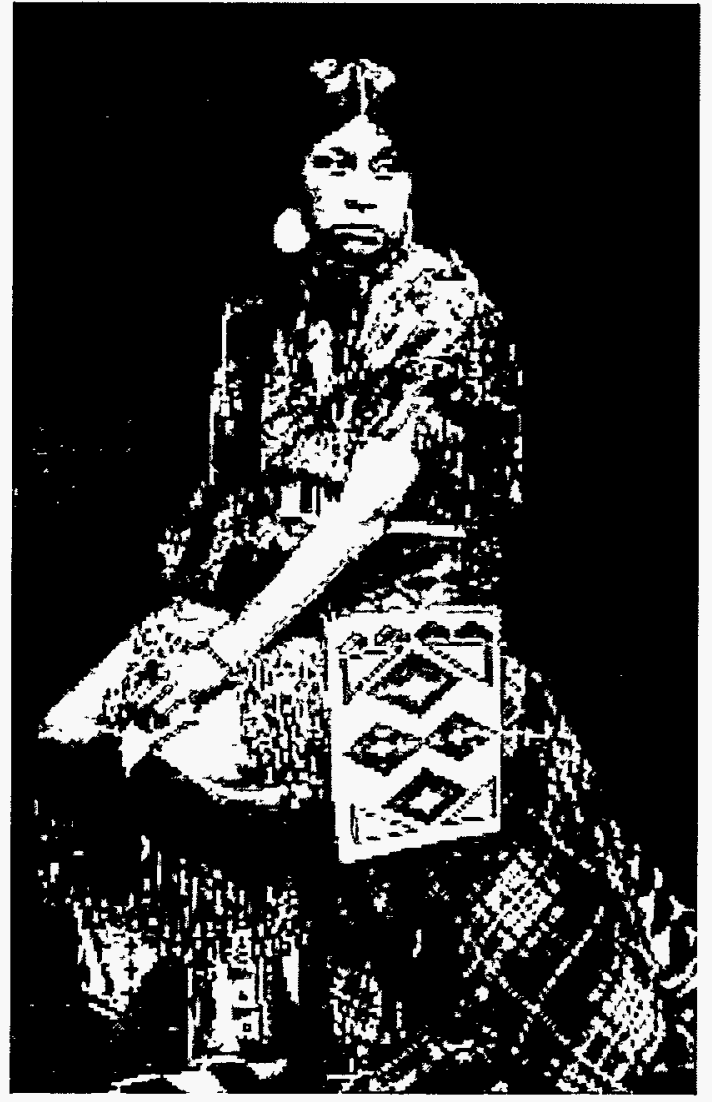

Her dress is heavily fringed with beads. The corn husk bag was common to Nez Perce and Spokane. 


\section{UMATILla TRIBAL PROFILE}

\section{LOCATION AND LAND BASE}

The tribes' homeland once encompassed 6.4 million acres in northeastern Oregon and southeastern Washington. The present-day reservation consists of 172,000 acres, with tribal headquarters located in Mission, Oregon, just outside of Pendleton, Oregon.

\section{TRIBAL ENROLLMENT}

The Confederated Tribes of the Umatilla Indian Reservation presently have 1,900 enrolled members, of which two-thirds live on or near the Umatilla Reservation. The Reservation is also home to another 1,000 Indians from other tribes, such as the Yakama, Warm Springs and Nez Perce, as well as nearly 1,700 non-Indians.

\section{LANGUAGE(s)}

dialects of the Sahaptin family (Walla Walla and Umatilla Tribes); Waiilatpuan (Cayuse)

\section{TRIBAL GOVERNMENT}

Federally-recognized Tribal Confederation pursuant to the 1855 treaty, including the Cayuse, Umatilla and Walla Walla tribes. Tribal affairs are governed by a nine-member "Board of Trustees." The board is elected by the General Council, which consists of all tribal members age 18 and older. The General Council also elects its own officers, and its chairman serves to represent the General Council on the Board. Day-to-day operation of tribal government is carried out by a staff of nearly 300 employees.

\section{ECONOMIC BASE}

An economy once based strongly on agriculture and natural resources has grown to include commercial development such as a trailer court, grain elevator, and the Wildhorse Gaming Resort and Hotel. Other projects targeted for completion by 1998 include: Tamustalik Cultural Institute, RV park, 18-hole golf course, entertainment park and convenience store/ gas station. When complete, these enterprises, along with tribal government, will boast a combined annual payroll of $\$ 13$ million, making CTUIR a major employer and economic contributor in Umatilla County.

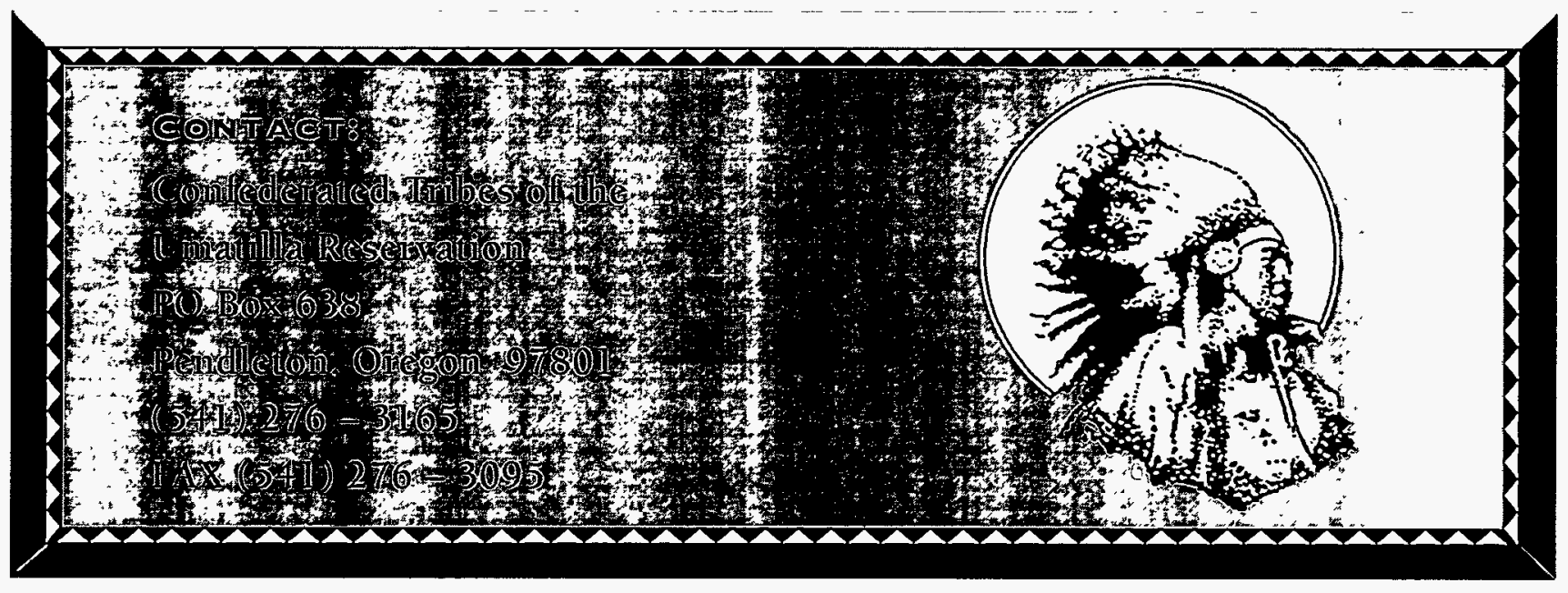


ADDITIONAL CONTACTS

Administration and Board of Trustees: 276-3165

Confederated Umatilla Journal

276-3165

Economic and Community

Development

Education

Fire Department

Health and Human Services

Housing

Natural Resources

Personnel

Planning and Enrollment

Police

Wildhorse Gaming Resort and Hotel
276-3873

$276-8120$

276-2126

276-7990

276-7544

276-3449

276-3570

276-3099

278-0550

1-800-654-WILD 


\section{UMATILLA}

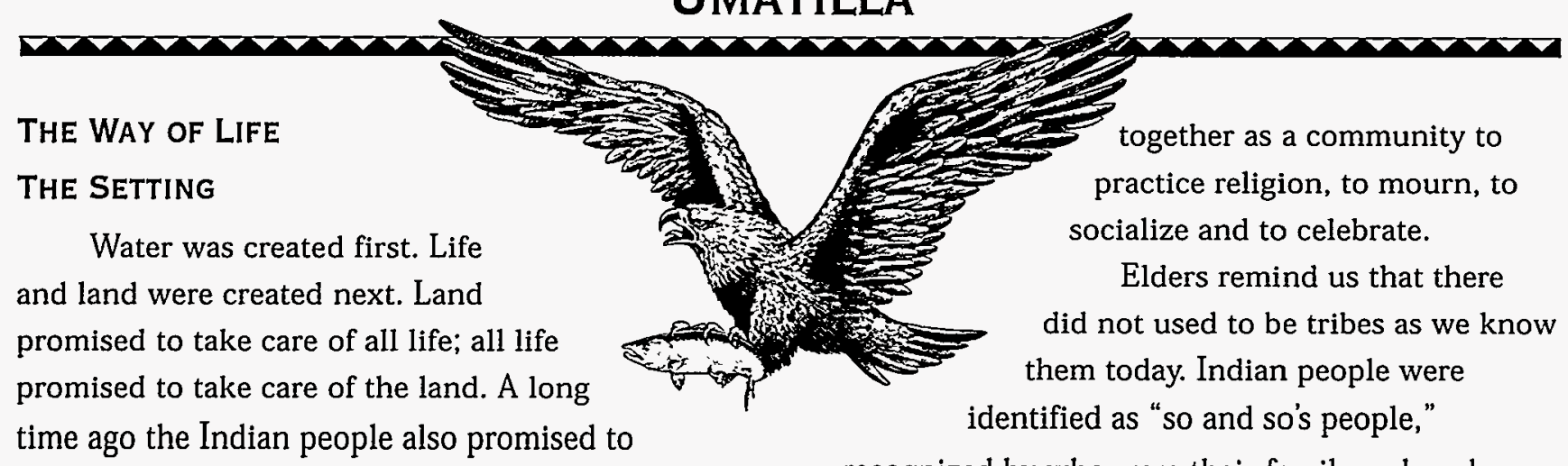

protect and care for the land. Water represents the integral link in this world view: water is sacred and extremely important in preserving precious balance. Water is the origin of life, and essential for the survival of all life.

Spiritually, the tribes do not separate themselves from the surrounding world. Individuals have a personal relationship with the Creator through the sweathouse and individual Weyekin (spirit guides). Larger groups reinforce this personal relationship with the land and the Creator in the longhouse. The longhouse is the community center where Indian people come

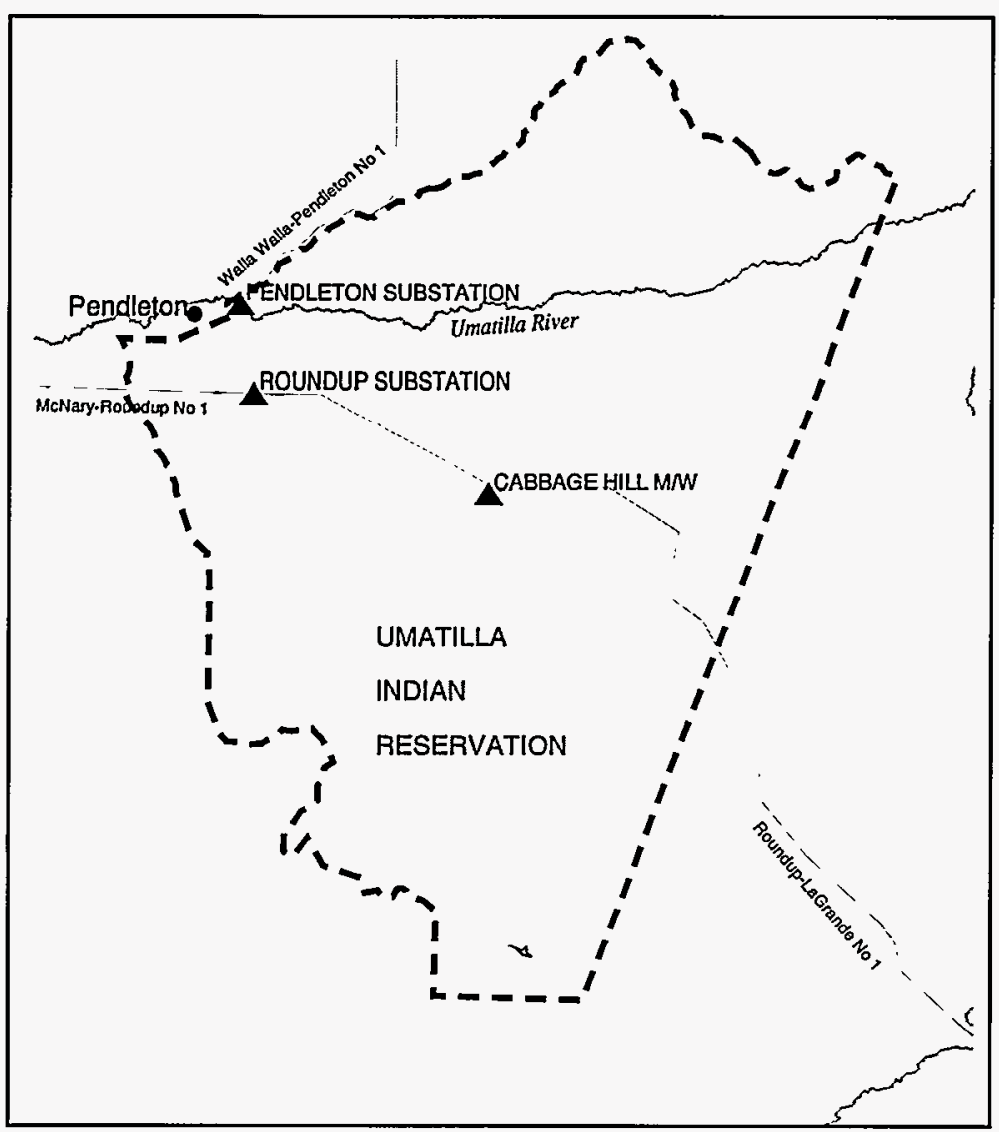

recognized by who were their family or by where they come from. Survival depended on working with each other.

Spring arrives on the Columbia Plateau with the fresh plants and the dramatic return of the salmon. Then, the First Foods feast brings together the tribe to celebrate the renewal of life cycles together with their community. Water is honored first at the feasts. Individual faith is also practiced on a personal level, such as through the sweathouse. The sweathouse is utilized to communicate with the Creator, for medicinal purpose, as well as to build one's physical and spiritual strength.

Fishing was the primary means of livelihood and survival for tribal members. Salmon ran during spring, summer and again in the fall. Some tribal members would stay at their usual and accustomed sites for the whole season, others for the entire year. The conditions along the Columbia and Snake River systems were so good that all that was required for a fisherman was a dip net, gaff hook, small spear, or a hook and line, depending on where and what season they were fishing. Fish were dried and pounded into cakes and packed into baskets for winter subsistence or commerce.

As seasons permitted, some tribal people would head into the mountains to hunt and gather plants, medicines and other resources, and to fish in the tributary headwaters. Salmon, huckleberries and other resources were gathered seasonally. Columbia River people traveled through 
the river system by canoe, and walked into the mountains, sometimes relying on dogs to help pack the load.

The winter on the Columbia Plateau is often hard and severe. Careful preparation for

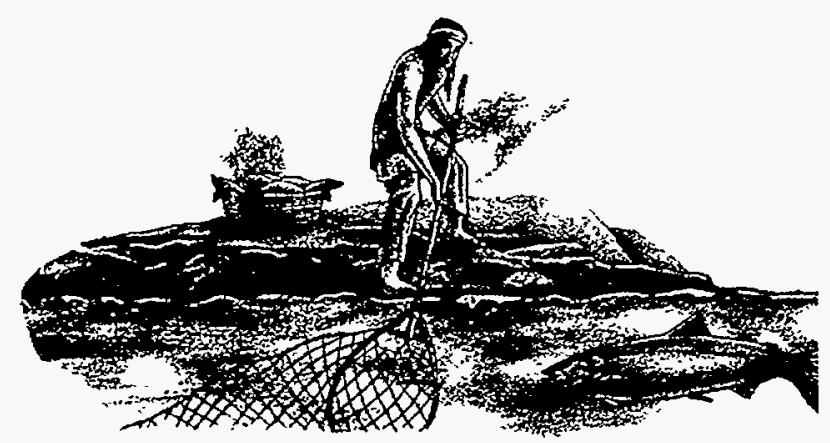

trade and economic interests in the Columbia River Gorge and the northern Plateau. The Walla Walla were mentioned by Lewis and Clark in 1805, and included many groups and bands that were often referred to by the village from whence they originated, such as the Wallulapums and Chomnapums. The Umatilla occupied both sides of the Columbia River from above the junction of the Umatilla River downstream to the vicinity of Willow Creek on the Oregon side, and to Rock Creek on the Washington side.

The Walla Walla and the Umatilla were a part of the larger culture of Shahaptian-speaking river people of southeastern Washington, Northeastern Oregon and Western Idaho.

The Cayuse, whose original language is known to linguists as Waiilatpuan, lived: "...south of and between the Nez Perces and WallahWallahs, extending from the Des Chutes or Wawanui river to the eastern side of the Blue Mountains. It [their country] is almost entirely in Oregon, a small part only, upon the upper WallahWallah river, lying within Washington Territory."

Prior to introduction of the horse, the Cayuse were tributary fishermen. After the arrival of the horse and gun they sometimes were mounted warriors to protect their way of life. Living throughout the lower Columbia Plateau from the Cascade to the Blue Mountains, they grazed horses on the abundant grasses of southeast Washington, the Deschutes-Umatilla Plateau. As horsemen, the Cayuse had close ties to the horsemen of the Palouse and Nimipu (Nez Perce).

The area from Wallula to the mouth the Yakama River where many members of the ancestors lived could be considered the crossroads of the Columbia River system. This area was 


\section{Human Remains Should Be Reburied}

This summer a human burial, believed to be about 9,000 years old, was discovered near Columbia Park in Kennewick, Washington. Scientists and others want to study this individual. They believe that he should be further desecrated for the sake of science, and for their own personal gain. The people of my tribe, and four other affected tribes, strongly believe that the individual must be re-buried as soon as possible.

My tribe has ties to this individual because he was uncovered in our traditional homeland - a homeland where we still retain fishing, hunting, gathering, and other rights under our 1855 Treaty with the U.S. Government.

Like any inadvertent discovery of ancestral human remains, this is a very sensitive issue for me and my tribe.

Our religious beliefs, culture, and our adopted policies and procedures tell us that this individual must be reburied as soon as possible. Our elders have taught us that once a body goes into the ground, it is meant to stay there until the end of time.

It is not our practice to publicize these types of discoveries, both for the protection of the individual as well as sensitivity to our tribal members. In this case, however, we must take the opportunity this incident has created to help educate the general public about the laws governing these discoveries and what these discoveries mean to us, as Indians. We also hope to give people a better understanding of why this is such a sensitive issue.

The Native American Graves Protection and Repatriation Act (NAGPRA) and Archaeological Resources Protection Act (ARPA), as well as other federal and state laws, are in place to prevent the destruction of, and to protect, human burials and cultural resources. The laws also say that authorities must notify affected tribes and consult with tribal officials on how to handle the discovery, as well as protection and preservation. Our tribe was not properly notified and if we had been, this difficult situation might have been avoided.

Under the Native American Graves Protection and Repatriation Act, tribes are allowed to file a claim to have ancestral human remains reburied. My tribe has filed a claim for this individual and when it is approved, we will rebury him and put him back to rest.

In filing this claim, we have the support of the four other tribes who potentially have ties to this individual. These tribes are the Yakama, Nez Perce, Colville and Wanapum. We share the same religious belief, traditional practices, as well as oral histories that go back 10,000 years.

If this individual is truly over 9,000 years old, that only substantiates our belief that he is Native American.

From our oral histories, we know that our people have been part of this land since the beginning of time. We do not believe that our people migrated here from another continent, as the scientists do.

We also do not agree with the notion that this individual is Caucasian. Scientists say that because the individual's head measurement does not match ours, he is not Native American. We believe that humans and animals change over time to adapt to their environment. And, our elders have told us that Indian people did not always look the way we look today.

Some scientists say that if this individual is not studied further, we, as Indians, will be destroying evidence of our own history. We already know our history. It is passed on to us through our elders and through our religious practices.

Scientists have dug up and studied Native Americans for decades. We view this practice as desecration of the body and a violation of our most deeply-held religious beliefs. Today, thousands of native human remains sit on the shelves of museums and institutions, waiting for the day when they can return to the earth, and waiting for the day that scientists and others pay them the respect they are due.

Our tribal policies and procedures, and our own religious beliefs, prohibit scientific testing on human remains. Our beliefs and policies also tell us that this individual must be re-buried as soon as possible.

Our religion and our elders have taught us that we have an inherent responsibility to care for those who are no longer with us. We have a responsibility to protect all human burials, regardless of race. We are taught to treat them all with the same respect.

Many people are asking if there's any chance for a compromise in this issue. We remind them that not only has this individual already been compromised, but our religious beliefs have once again been compromised. Many nonIndians are looking for a compromise - a compromise that fits their desires.

And, many non-Indians are trying to bend the laws to fit their desires. The Native American Graves Protection and Repatriation Act was passed by Congress in 1990 to protect Native American burials and set in place a mechanism to have human remains and artifacts returned to the tribes.

We are trying to ensure that the federal government lives up to its own laws, as well as honoring our policies, procedures and religious beliefs. We understand that non-Indian cultures have different values and beliefs than us, but I ask the American people to please understand our stance on this issue. We are not trying to be troublemakers, we are doing what our elders have taught us - to respect people, while they're with us and after they've become part of the earth. By Armand Minthorn, Board of Trustees member and religious leader with the Confederated Tribes of the Umatilla Indian Reservation

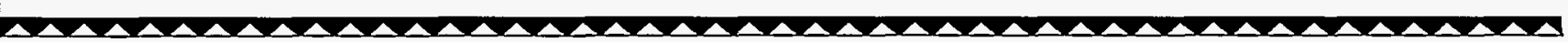


shared by many related bands and was a central hub of tribal life on the Columbia Plateau.

Extended family relationships, social and economic interests exist among many tribal people from throughout the Columbia Plateau. The people on the Columbia Plateau were multilingual. Tribal members learned and spoke several trade jargons, other Indian dialects of Shahaptian, as well as Salish, Chinookian and Klamath. Later they adapted to French and English.

Inter-tribal relationships were based on many needs key to the survival of Columbia Plateau life, such as military security and protection, trade and economic prosperity, education, religion and family ties.

Their geographic setting placed the Umatilla, Walla Walla and Cayuse in the role of middlemen between the buffalo country of the Great Plains and rainforest and ocean resources of the Pacific Coast cultures. Tribal members relied on trade goods from the plains such as buffalo meat and hides, obsidian from the south as well as abundant seafood, plants and medicines from the Pacific Northwest coast.

Gatherings were held at many places throughout the region. Very large gatherings were known to be held in the Wallula area near the confluence of the Snake River and at Wascopum near the ancient fishing grounds of Celilo Falls and Nine Mile Rapids. Smaller gatherings were held in the many fertile river valleys in the region where peoples' paths crossed during their seasonal rounds. At such gatherings many traditions such as language, religion, ritual, music, dance, legends, stories, feasts, sport, gambling and family values were continued and passed on.

Trade and barter was a significant aspect of Indian life on the Plateau and essential for the survival of Indian people. Indians relied on other Indians to provide goods they themselves were not able to obtain, were not available during their seasonal round, or not available in their country. Often groups from a single village community would travel different directions as part of their seasonal round. Through years of trade relationships, elders knew exactly what other Indians needed in exchange for goods they needed.

Life on the Columbia Plateau was recorded by the people in traditions and art. Songs, dances and stories that embody the history of the Indian people are passed down from generation to generation by oral transmission. Stories and symbols were woven into the many baskets, hats and bags utilized by the people. Basketry evolved as a crucial survival tool and an art form. Elaborate balls of long hand-woven string kept track of many events of the people's history. Rock art, cairns and unique geological formations were present at many locations providing reference to the people's lives. Personal histories are reflected through the individuals preparation of personal regalia and dance. Wealth was personal strength, family, community, comfort and happiness.

Individual abilities were recognized by elders at an early age. Headmen and chiefs were selected based on their experience, abilities and skills. Elders were respected, 


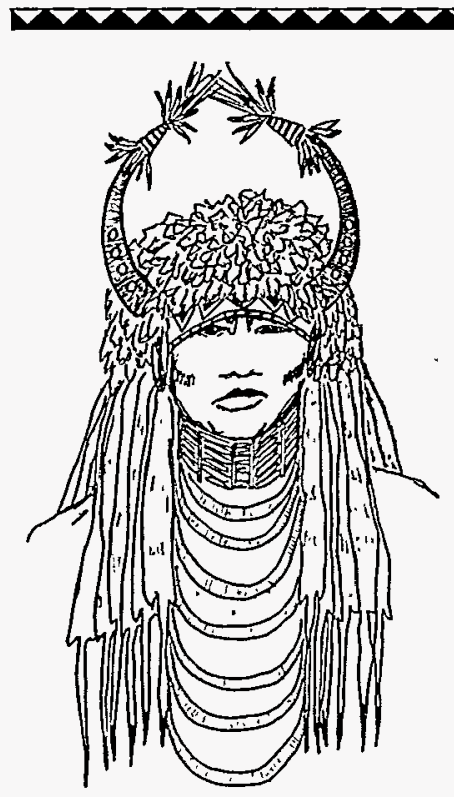

\section{The Elders Speak}

Talking about different kinds of medicine dances: Chinook Dance warms the weather. There was hard times, and there would be special people singing for the people, or a special individual singing for a person having hard times. This is a true incident that happened in Athena: Farmers came to see a man whose name was Shefland, to do a dance to clear the weather because the animals were freezing in the bitter cold. They asked him if he could do that, and he said that he could do it, but not himself. He needed something else, whether it was the Creator, or everybody focusing on the one thing. He didn't take pay for it. All the people were there, and they sang for weeks. They made tule mats and made a long tent from them, overlapped like a shingle, and they sang all that week. It happened. It's written in the Oregonian a hundred years ago. It was a special gift, and I guess you had to think about your people and what you had to learn in order to survive. Medicine people led the dances. There were all different dances, healing dances: Chinook dances, and feather dance people. Everyone had a different song. Whatever spirit he had. There were war people. There were bad people, people who didn't listen to others, ignored other people; they had something inside of them, and they had doctors to take that thing out. Medicine people never kept anything inside of them. These people are all gone. In their teachings, they always started out, "In the beginning..." They never said, "I did this, or I did that." It makes it hard to explain to the anglo people, because they never explained. Today, even the children of the medicine people ask, "Why did they do that? What are these things?" We would call them holy men, or medicine men. The people had to have strong power, because they believed in the Creation. We don't see it, and you don't see it, but we know the things are out there.

Raymond Burke

and often leaders had council with elders.

Individuals were recognized for their spiritual strength, medicinal abilities, warrior qualities, hunting and tracking abilities, fishing skills, art, weaving, education, discipline, healing, cooking or other skills. Labor and skills were divided as many survival skills were necessary.

Planning and preparations were conducted in ways that anticipated the needs of future generations, and conflicts and issues were resolved by council of elders and leaders. Leaders were decisive when they believed that their followers had arrived at a consensus. If there was no consensus, powerful orations between the headmen and chiefs might soon swing the people on issues or problems of the day. If an individual disagreed with the decisions of the band he was not forced to comply with the decision.
Following the introduction of the horse to the plateau in the 17 th century, the tribes owned a tremendous number of horses. The bunch grass covered hills of Columbia Basin was the home of the Cayuse and Appaloosa, as well as pintos, paints and mustang horses.

Appaloosas were bread for speed and ceremony by the Cayuse, Palouse and Nimipu. The Cayuse Tribe was known for their large horse herds that grazed in the foothills of the Blue Mountains. Cayuse ponies were stout and able to move quickly through the steep and timbered Blue mountains. Prestige and wealth was partially reflected by the number of horses that a person owned. Tribal elders tell us that in those days the Indians had thousands and thousands of horses. There wasn't enough grazing area, so they had to spread the horses out. The Cayuse used to graze horses all through the Umatilla Basin, north from 
across the Columbia River on the Horse Heaven Hills to Hanford; east of the Blue Mountains from the Grande Ronde country to Huntington; south to the John Day River country; and west to the Cascade Mountains.

The horse expanded Shahaptian and Cayuse culture, improved mobility and brought the Cayuse, Walla Walla and Umatilla into contact with other Indian cultures in Montana, Wyoming, Canada, California, Nevada and throughout the Pacific Northwest. Horses allowed for new ideas to be introduced from new places, as well as allowing other Indians to travel and trade along the Columbia River.

\section{HISTORICAL TIMES}

Disease had already moved up the Columbia River prior to the arrival of American explorers Meriwether Lewis and William Clark in 1805. The Spanish reached the northwest coast as early as 1775 , and the English in 1796. European contacts at the coast spread disease rapidly inland, which claimed entire villages. By the time Lewis and Clark traveled the Columbia it was estimated that two different outbreaks of western disease had decimated the people living along the big river.

No government at the time doubted that resident tribes had the superior military capability and controlled the region. Tribal peoples knew the land intimately and were considered as necessary and crucial allies by Euro-Americans. Without direct involvement with the tribes, Euro-American interests could not compete with each other. Since the French and Indian War, alliances with Indian tribes were highly desirable on political and economic levels.

To entice the Indians into the fur trade, the traders introduced new technological goods such as steel, knives, pot, pans, blankets, etc. The fur companies in fact had already established a long tradition of working with Indians to exploit their knowledge of the environment. Iroquois Indians employed by fur companies came to live in the
Pacific Northwest. Fur traders, however, had to make local connections, and the tribes eventually became involved in the competition for furs. Indian regulation of trade was enforced by the headmen and chiefs. The Northwest Fur employees abided by the rules set down by the Indians simply because of the control the Indians exerted over their neighbors.

Initially the tribes viewed the goods and supplies that foreign traders and trappers offered as a welcome addition to their already thriving economy. Fort Nez Perce was established sometime around $1817-1818$ as a trading outpost at the confluence of the Walla Walla and Columbia River. In 1835 it was renamed Fort Walla Walla.

\section{THE MISSIONARY ERA}

Contacts with the trading posts had initially introduced the Indian Nations to Christianity. This was done through British Protestants and FrenchCanadian trappers who were for the most part of the Catholic faith. The trappers were much impressed by the native religion in the area and found no conflict between Christianity and native religion. Fur companies often encouraged their men to take Indian wives and marry into the tribes to strengthen trade relationships.

Protestant missionaries had been in contact with Indians and some of the headmen in the region. The American Board of Foreign Missions in 1835 promised to locate missions in Cayuse and Nez Perce territories. In 1836, Dr. Marcus Whitman and Henry Spalding arrived at Fort Walla Walla. Whitman founded his mission with the Cayuse at Waiilatpu near Walla Walla, Washington. Spalding was assigned to convert the $\mathrm{Nez}$ Perce people and founded a mission at Lapwai, Idaho.

In 1838, two Catholic priests, Fathers Blanchet and Modesta Demers of the Diocese of Quebec, arrived at Fort Walla Walla to estimate the possibilities of beginning a Catholic mission in the territory. Saint Rose of the Cayuse was 


\section{Timoy-Timoy Nima}

A long time ago, at a place called Timoy-Timoy Nima, where Rock Creek comes into the Grand Ronde River, in the Grand Ronde Valley, there is a place that is present day Baker City. Two men on horseback were riding into the valley, and they came upon some Shoshone Bannocks. The Shoshone Bannocks asked the two men where they were going. They talked using their hands, using sign language, because they didn't understand one another's language. These two men indicated that they were going to where the Indians are. "Where are the Indians?" they asked.

The Shoshone Bannocks told them they were in luck, that there was a place on the Grand Ronde River where the Indians had gathered, and they named the place: Timoy-Timoy Nima.

The two men on horseback asked them, "Can you take us there?"

The Shoshone Bannocks said, "No, this is their country, and we don't want any trouble with them. This is their country. But we can take you part way." Then the Shoshone Bannocks led them on horseback into the Grand Ronde Valley. When they got there, they stopped and would not take them further, saying, "When you hit this river, follow it, and you will come to this place."

The two men on horseback rode into the valley and came to a place called Cup-Cuppa, which is present-day LaGrande, Oregon. While in this valley they came upon two fur trappers. These fur trappers asked them what they were doing there. They asked them, "Where are you going?"

The two men on horseback replied, "We are going to this place where the Indians are gathered."

The fur trappers said, "We know where that is. It is on the Grande Ronde River at a place they call TimoyTimoy Nima...we can take you there." So they followed the Grand Ronde River and came to the top of $a$ hill and looked down in the valley. The two men on horseback said it was the most wonderful sight they had ever seen. There were Indian camps on both sides of the river, and up the river, and down the river. They came down the hill, coming toward the camp, and they stopped again, and marveled at the sight. Then they saw one man riding through the camp on horseback, yelling at the top of his voice. The two men on horseback asked the fur trappers, "What's that man doing? What is he saying?"

The fur trappers said, "That man is the crier, the man who organizes the people and tells them to get ready. What he is saying, he is telling the people, 'Get ready...it's time...the fish are here, the roots and the berries are here. It's time. Let's get ready to give thanks to our Creator for this food that has been given to us as Indian people. Get yourself ready, it's time."”

The two men on horseback looked at one another, and then at the fur trappers.

The crier rode into a different part of the camp and began talking in a different language, still yelling at the top of his voice. The two men on horseback asked the fur trappers what he was saying. The fur trappers said, "He's telling them the same thing. That it is time to get ready to thank the Creator for giving them the land that gave the food to them. It's time. Get ready."

Then the two men on horseback looked at each other; looked at the fur trappers, then looked again at the big camp of Indians.

The fur trappers asked, "Why have you come to look at them? Why are you here?"

The two men on horseback looked again at the camp and couldn't get over the sight. Then one of the men reached into a sack and pulled out a black book. He said, "This is why we are here. We are here to bring them this book." Then they looked again at the camp, and said: "There is no reason for us to be here. We came here to bring them this book. We came here to bring them God. But they already know. They already know who God is, and they know how to give thanks. There is no reason for us to be here."

So they turned around and left.

The old man who told this story said that these two men who came up with this book came from the south, and they were Mormons. The old people told this story, and it substantiates that our beliefs were handed down long before the white man came. We've always had a religion, and we've always known who our God is, who our Creator is. This is what we've been told, and the songs we sing today echo that same thing. These songs tell us how time began, and they tell us how time will end. We already knew. This is the story that I share with you. 
established near Walla Walla. In 1847 Father John B. Brouillett established a mission called St. Anne along the Umatilla River in a cabin donated by Chief Taawitoy.

In 1847, Dr. Whitman and his followers were killed by a band of Cayuse, along with some of their Umatilla and Nez Perce allies. The reasons for this are many and varied but included nonpayment for property taken by the mission; increasing immigrations; Whitman's encroachment on Indian trade; fear of Whitman himself, whom the Indians believed had poisoned them; and the constant outbreaks of diseases introduced by Whitman and other non-Indians that had reduced the tribes' population by half. Whitman claimed to be a doctor and preacher as well as being a missionary, merchant and trader. In the tribes' tradition, punishment for failure by a medicine man was sometimes death, especially, when people's lives were believed taken by that medicine man.

After the events at Whitman Mission, the cabin that housed the St. Anne mission on the Umatilla River was burned. It was almost two decades before the Catholic Missionaries returned.

Differences in Indian and non-Indian values and attitudes set the stage for the so-called "Cayuse War" of 1847-1850. Actually, the "War" consisted of minor skirmishes with Cayuse-led war parties against the territorial militia. In response, the Oregon Territorial Militia often massacred any unfortunate Indian they stumbled across. The war parties were represented by mostly interior tribesmen who felt compelled to turn the immigrations back.

The war ended in 1850 when five Cayuses sacrificed themselves to stop the violence and injustice toward their people. They were convicted of killing Whitman and were hanged in Oregon City. They were essentially sentenced whether guilty or not to appease non-Indian concerns and fears. The fact that Whitman was believed to have brought disease to the tribes, and was encouraging

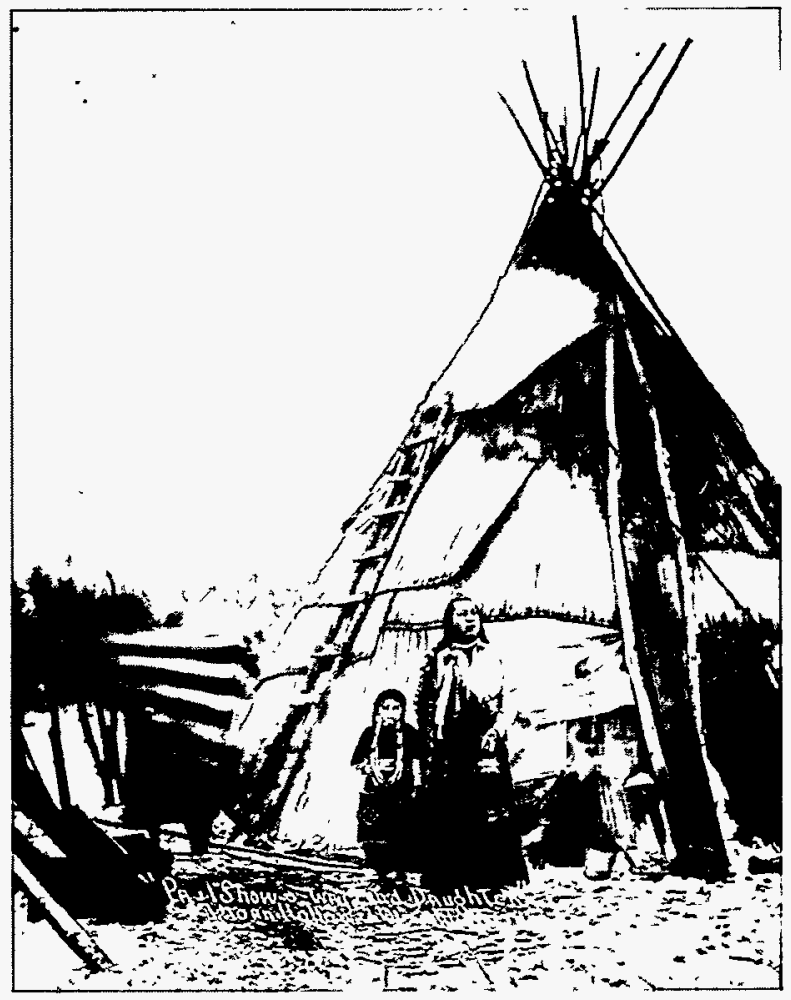

non-Indians to take Indian lands, never entered the case.

\section{IMMIGRATIONS}

The first wagon train into the Oregon Country arrived in 1843 . Nearly 900 immigrants crossed the plains to the Pacific Northwest that year, and an estimated 1,200 settlers followed the Oregon Trail in 1844. The number swelled to 3,000 in 1845 . The controversy between the American and British governments over the American/Canadian boundary in the west was settled by treaty in 1846 , inaugurating the great tide of migration in 1847, when an estimated 4,700 settlers came into Oregon.

Pioneer journals from the Oregon Trail mention meeting Cayuse families returning from buffalo hunting in the mountain valleys of Idaho. Quite often, the tribes traded their fine horses, and later their harvested vegetables, with the explorers and immigrants for cattle, clothing, blankets and utility items. Their descriptions also alluded to the wealth of the land. 
"....we are now traveling down the Umtillo river the Indians hear has a great maney horses very fatt and the best I Ever Saw in my life they are very Rich som indians has from 50 to 100 horse and cattle in propostion they raise plenty of Corn and potaters and peas pumpkins squashes cabeges $E c$. this Countery is very fertile...."

Absalom B. Harden, Journal, 1847

Estimates from 1842 to 1849 indicate a total of 12,287 immigrants moved through tribal homelands. The Indians' view of the immigration were mixed. The tribesmen saw the travelers as poor people moving through the country. Their horses and cattle were as exhausted as the immigrants themselves, who were often dirty and hungry. Certainly there were cultural differences between Indians and non-Indians, but early relations were marked by diplomacy, communication and consideration. After time, however, non-Indians began to take land offered by the U.S. Government - land that the government did not own.

As immigrations began to increase, the tribes heard rumors that government representatives were plotting to steal the homelands. The Donation Land Act of 1850, and territorial approval of settlers in the Columbia Plateau without regard to tribal consent, made for a pressure-packed situation. The American government was encouraging its citizens to move to the Oregon Territory without first extinguishing the Indians' claims to their lands. As more and more non-Indians entered the country the mood became hostile. Indian uprisings and wars erupted in protest of this invasion. This made the fur traders, missionaries, settlers and the government uneasy. Eastern Oregon was essentially closed to non-Indians for a period of twelve years.

In 1851, the tribes negotiated with Anson Dart, the Commissioner of Indian Affairs, whom wished to build a sawmill. Instead of a sawmill, the Utilla Indian Agency was built on the banks of the Umatilla River near present-day Echo, Oregon.
This agency was burned down. With the increasing influx of settlers, miners, soldiers and cattlemen, the tribes began planning to rid themselves of the intruders once again. In early 1853, plans were agreed upon by Kamiakin, of the more numerous Yakamas, as well as most of the interior tribes who had heard the rumors to displace them. Word was sent out by runners contacting other tribes in the Northwest. Councils were met with tribes from northern California, Shoshone and Bannocks in Southern Idaho, and Flatheads of Montana.

By 1854, Oregon territorial governor Joel Palmer convinced the Indian Department that no further settlements were to be established east of the Cascades until the Indians there could be moved to reservations by treaty. By the end of July, Congress authorized negotiation of treaties in order to purchase the Indian lands, and establish a reservation for Indians.

On May 29, 1855, a Council was convened at the old Indian grounds on Mill Creek, six miles above Wai-i-lat-pu in the Walla Walla valley to discuss the situation in Eastern Oregon and to negotiate a treaty. Officiating were Isaac I. Stevens, Governor and Superintendent of Indian Affairs for the Washington Territory, and Joel Palmer, Superintendent of Indian Affairs for the Oregon Territory. They met with chiefs, delegates and headmen from the Nez Perces, Cayuse, Walla Walla, Yakamas and Palouses, as well as representatives of other tribes present.

The Treaty of June 9,1855 between the United States and members of the Walla, Cayuse and Umatilla tribes was signed. The Treaty Council of 1855 at Wai-i-lat-pu had profound impacts on the Columbia Plateau. The Umatilla Indian Reservation, the Yakama Indian Reservation and the Nez Perce Reservations were created during these negotiations. Originally Stevens and Palmer had planned on putting all the Indians in the region on the Yakama Indian Reservation. The treaty negotiations determined 


\section{The Elders Speak: The Whipman}

The "whipman" was a normal feature of what has come to be called "Plateau Culture" by academic ethnographers, appearing among most Interior Salish and Sahaptian tribes and bands. An honorary role held most often by a single male, the whipman traveled set routes among the people, dispensing both mild punishment and counseling. He traveled on a yearlong timetable, disciplining virtually all children on the theory that each child required some discipline for some act committed between visits. The whipman served several cultural purposes: he created solidarity among the cohort that he disciplined; he sent a clear message that no single child was above discipline; he provided dispassionate discipline, which not only freed the parent from the disruptive (to the family) role of punishing children, but often strengthened the bond between child and parent, who comforted the child after the whipman's visit; and, finally, he reinforced the cultural value that each child was a member not only of the family, but of the tribe as well, with the responsibility to be a good tribal citizen.

The first time I remember a whipman came to the house - he was Johnson Chapman - we could see him riding on the hill. You could look on the north horizon across from the house. He'd ride in by Watkins at the mouth of Dry Canyon north of McKay Creek. He'd come down and visit for awhile, and we'd figure maybe he wasn't going to come. Sure enough, here he'd come; and we'd run down to talk to him, talk to him real good. Then we'd get back up to the house ready to eat, and there'd be a blanket on the floor. And he'd disappear and come back with these willow sticks. My grandma would put on a beaded belt or a blanket as a gift. It didn't seem right to me that he'd get a gift for whipping me, and get a meal. But whether we did anything bad or not, after we got our whipping he'd sit us down and counsel us. He'd tell us why he did it, for discipline. It seemed to me that he would come in the spring, early spring, and in the middle of summer, and late in the fall. We wouldn't see him for awhile. But after years when we'd see him we'd run down fishing or something. And when we got back, he'd still be there. We would get counseled...not necessarily by whipmen. I know George Spino, Inez' father, never did whip me, but he always counseled me. Tom Joe the same way. These were big men on McKay Creek, stern looking men. If you were doing something, and they gave you the hard look, you knew you were doing something. There was another time, I always noticed that my grandmother always used to carry a shawl or blanket. And we went to Mitchell Lloyd's place before he got bedfast, and she said, "You kids stay out there for awhile." Then she called us in, and we got whipped again. Everytime we left home with her, we tried to be on our best behavior. It's modernized today that spanking is abusive, but I do believe that it was very good counseling for us, what I remember of it.

Jesse Jones otherwise. The Umatilla, Walla

Walla and Cayuse tribes agreed to live on the Umatilla Indian

Reservation. The Cayuse

Reservation boundaries were outlined and agreed to on June 9 , 1855. The Cayuse, Walla Walla and Umatilla had ceded 6.4 million acres to the United States, in return for which they reserved fishing and other rights, as well as reserving 510,000 acres on which to live. The treaty was subsequently ratified by Congress on March 8, 1859.

By 1858 , the materially superior forces of the Americans had prevailed and most of the warring tribes were at peace. Because of the prolonged wars and conflicts with the United States the Indians were impoverished and greatly reduced in number. To make matters worse, the Shoshoneans begin to take advantage of the war-weakened Shahaptians of the region by constantly raiding for slaves and stock.

\section{GOING TO THE RESERVATION}

The federal government forced the Indians onto the Umatilla Reservation and the ceded Indian territories were declared Public Domain and were auctioned at public sale, usually to land speculators and the railroads. $\mathrm{G}$. $\mathrm{H}$. Abbott was given orders by the Indian Department and forced by the settlers, under threat of hanging Indians, to move the Cayuses, Umatillas and Walla Wallas to their reservation. By this time, many settlers had moved into the Walla 
Walla Valley and conflicts between the Indians and nonIndians were commonplace.

As for the Indians on the reservation, there were problems with ever-increasing immigration both east and west. Whiskey peddling, horse stealing and other depredations by the outsiders were beginning to cause the superintendent of the Umatilla Agency many problems.

The transition to Reservation life was not easy. The tribes and bands at the Walla Walla Treaty Council maintained close family or traditional ties. Families and friends had to determine where and on which reservation to live. It was not an easy decision. The decision also meant a change in lifestyle. Instead of relying on each other, Indians were taught the Christian work ethic and self-sufficiency. Many of the people went to raising gardens along the Umatilla in one- to five-acre lots. Trade continued with the non-Indians. The people still had many horses and were able to fish for salmon, which was still the heart of their economy.

Leadership on the reservation was constantly challenged by the agents assigned in the early 1860 s. The agents were charged with educating and civilizing the Indians. Conflicts arose when the agents did not use the chiefs and headmen, or when the agent directly supervised the people without the consent of the leaders. Some of the elders have stated that agents refused to recognize traditional leader purposely, because the treaty called for annual payments to the chiefs of the tribes that the government representatives did not want to pay. Children were educated by the Catholic or Protestant missionaries at schools where strict discipline was enforced. Their hair was cut, uniforms were worn and they were punished for speaking Indian.

Some Indians refused to go live on the reservations. Homli and Smohalla were amongst those who refused to go to the reservations. They were concerned about their traditional ways, the old ways. They were not interested in the new God, farming or new ways of life. They only wished to live by the unwritten traditional law.

\section{The Whipman (continued)}

We stayed out on our place off the reservation. The whipman was called the English name "Matches." He lived on the hill just above Cayuse. Where we stayed you couldn't see anyone until they came over the horizon. We used to stay in Cayuse in the summer time, and when the fall came we'd move up to Adams. I remember down by Cayuse he was always coming down the hill. I was raised with my cousins, and the majority of us were girls. The oldest was Willard. He was always doing something to us, making us cry. We thought we'd get even with him. When the whipman came, he'd never get the willows himself, he'd make us get them, and if they weren't big enough, he'd send us back out to get bigger ones. Then they'd put out a blanket. It seemed we lined up according to age. He'd say, "What did you all do wrong." We'd tell him, "Willard was the bad one. He was the one that made us do that." So the old man said, "Alright then." Willard said, "I wasn't the one who did it, it wasn't me." The old man believed Willard, and we all got whipped and he didn't.

It was a way of discipline, and we never held it against the whipman. That's what's wrong with a lot of our young ones now, they don't even know what the word discipline means. We took care of each other, and that was one way of taking care of us, letting us know the difference between right and wrong, and the counseling. I think we listened to other people more than to our own parents, because we were so used to hearing their voice. When I talk to my grandchildren about it, they are just in awe. They can't understand how a man could just come and whip you for nothing. And I tell them that that is why I am who I am, because of all the things that have touched my life.

If we were stronger with our children, they would feel good within themselves, and they wouldn't have to look to other things to feel good. I just had an experience with my grandchildren. I talked to them and told them that they had to learn to like themselves. All the things we learned growing up has stayed with us. When I drive down those roads now, all those places are gone. Nobody lives in them. They've either been sold or something has happened. The old people used to say, "As long as you have the land, you have something." I think the whipman was a good thing in our time. I don't know if he would fit in with this time. Elizabeth Jones 
The reservation boundaries were under attack even before it was surveyed. Public meetings were held in LaGrande, Pendleton and Walla Walla by the late 1860 s, to remove the Indians from the Umatilla Reservation. The settlers had discovered that Indian lands were capable of producing wheat, and the mountains were good for livestock grazing. Roads and trails were utilized by the whites encroaching on reservation lands. The settlers hoped to push the tribes into another war, so that the Reservation could be extinguished once and for all.

The tribes had reserved 510,000 acres for the Reservation in 1855 . The reservation as it was actually surveyed totaled approximately 245,000 acres, or approximately half of the reservation reserved by treaty. Much of the debate arises over the location of "Lee's Encampment," whether its location was at Meacham where the boundary was surveyed, or at a location where a Major Lee of the Oregon Militia once camped, or at a place by Five Points Creek on the Grande Ronde where Jason Lee the Missionary once wintered.

Non-Indian encroachment on tribal lands continued to cause problems, especially if the Indian land had any exploitable value to the nonIndian. In 1877, the lower Nez Perce went to war over their homelands after others re-negotiated and sold their reservation lands out from under them because non-Indians had an interest in the land. Members of the Cayuse Tribe frustrated at the changes and pressures brought by the United States fought with Joseph and his people in the Nez Perce War. Other tribes such as the Yakama and Bannocks would also end up fighting against the injustice on non-Indians claiming their homelands. This encroachment was devastating to tribal culture and economic well being.

By the 1880 s, the 1855 treaty and reservation had been breached by non-Indians many times: the Walla Wallas were never paid for Peo Peo Mox Mox's land claim; the Oregon Trail was not moved south of the Reservation; the reservation boundary was mis-surveyed; the town of Pendleton was asking for 640 acres of the reservation; and the railroad was making plans to come through the reservation. By direction of the Secretary of Interior, an Indian Agent arbitrarily drew a line and removed the southern reservation.

\section{ASSIMILATING THE INDIANS}

In 1885, the Slater Allotment Act was introduced and it turned out to be a prototype for the establishment and subsequent sale of "surplus" Indian allotments, known as the Dawes Allotment Act. Under the Dawes Allotment Act, tribally-held Reservation land was broken up into individual allotments that were granted to tribal members and some non-Indians. Unallotted lands were made available for sale to the public. By 1887 the Dawes Allotment Act was in full swing. Approximately 100,000 acres on the Umatilla Indian Reservation were allotted to non-Indians, and another 30,000 acres were put up for sale. The stated goal of the Act was to acculturate tribal members by intermixing non-Indians among tribal members. However, most of this allotted land was used for agriculture, specifically wheat and livestock.

Indian agents on the reservations were ordered to "educate and civilize" the Indians, which meant missionaries, schools,

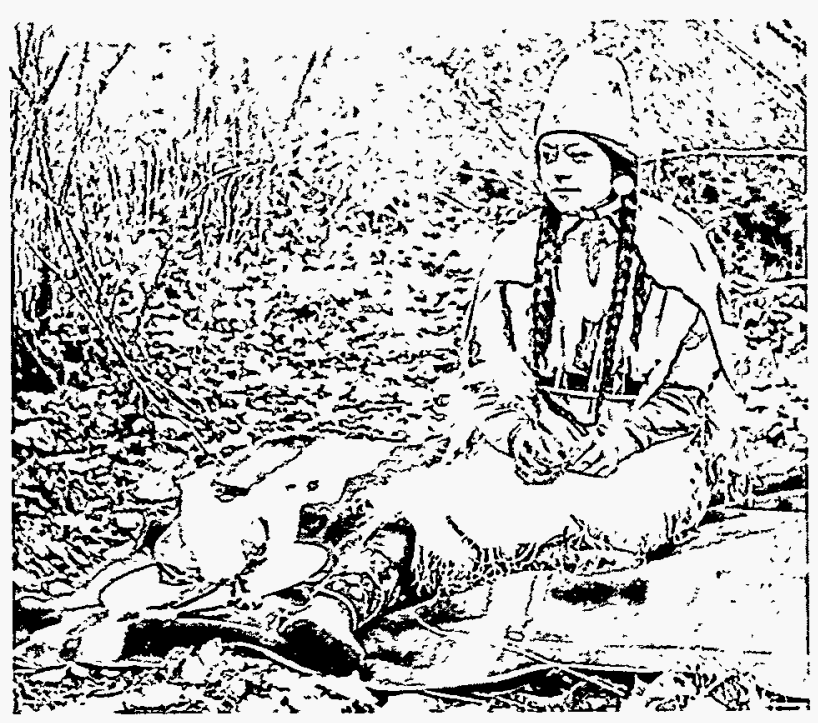


apprenticeships, farming, and the allotment of lands. By 1890 , Indian treaty lands in the United States had been reduced by half. The Umatilla Reservation, through the Dawes Act, was reduced from 245,699 acres to 158,000 acres. Many "forced" fee patents were issued to individuals who were described as being "competent" by the agent and his "committee from town." Indians and "breeds" weren't often considered competent. Much of the 87,699 acres not allotted was purchased by land speculators, timber speculators or sheep industries.

With the influx of non-Indians came many new things and ideas that would affect the Columbia Basin. With the settlers came land ownership, fences, livestock, agriculture and new species of plants some of which are now considered noxious weeds in the basin. At the time, the tribes began to take residence on the Umatilla Indian Reservation and non-Indians began to make the majority of decisions about the use and management of the environment.

\section{THE TWENTIETH CENTURY}

The next century would be a harsh introduction for the tribes to paper laws, politics, money and greed in the American capitalistic and democratic system. Four decades after establishment of the reservation a number of Congressional Acts were passed. The tribes started the twentieth century playing legislative catch-up, trying to find out what had happened to our homelands. The acts for the most part were landbased, punitive actions on the part of Congress to correct the failing Allotment Act of 1887. The perceived failure of the Allotment Act was that it had failed to integrate Indians into American society.

The Miriam Report of 1928, a comprehensive study of post-Congressional acts and their impact on the Indian communities, indicated mismanagement of Indian affairs by Congress and

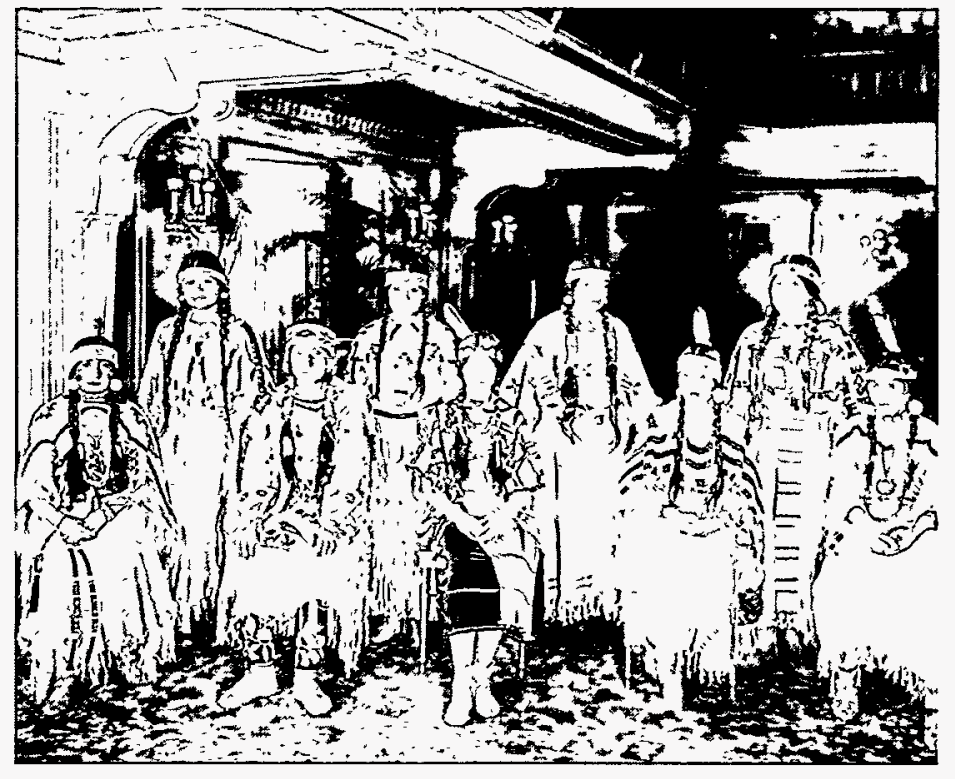

recommended a change in policies. As a result of the 1928 Miriam Report, the Indian

Reorganization Act of 1934 was offered to the Umatilla Tribes as a reform of the federal government's Indian policy. The Indian Reorganization Act offered official recognition for tribes by the federal government along with the fulfillment of obligations outlined in the act, in return for which each tribe was expected to reorganize its traditional decision-making apparatus along modern corporate lines.

Historically, the U.S. Government, through its departments and agencies, has managed Indian affairs and resources on the basis of trust responsibilities to the tribes implied in the treaties. That trust responsibility, as amplified by several court decisions, requires the U.S. Government, when managing Indian assets, to manage them in the best interests of the tribes. At the time of the Indian Reorganization Act, reservation dwellers were relatively satisfied with the Bureau of Indian Affairs' handling of its trust responsibility in the wake of the Dawes Act, particularly the Bureau's success at getting Indian lands returned to trust. More important, this system allowed the tribe to employ traditional decision-making, meaning family leaders meeting in council. 
The Elders Speak: The Creation of Celilo Falls

In the beginning all things were created. Through Coyote, the Creator created a lot of the things he was going to pass on to another creation he had in mind [the creation of human beings]. The story goes that three sisters were swimming in the Columbia River. Coyote was on the other side, and the sisters were on this side, three beautiful women. Coyote thought, "Gee, I'd like to get closer. I got an idea..." Coyote always had ideas...so he went way up the river by Umatilla, and got a great big log, and he fastened himself to the log. He floated downriver, and he was getting a little closer. He thought, "I'll capture one...but which one since they all look beautiful?"

One of the sisters glanced back at the river, and she thought, "That looks like Coyote." She pretended not to see, but she told her sisters, "Guess who is coming down the river?"

They all knew, and let him come closer and closer. He was getting an eyeful. He got closer and closer, and just before he made his move, one of the sisters started moving farther into the river. He didn't know each of them had power, and that the combined power could move him wherever they wanted. They started changing the current in the river, and he was rolling around on the log, and his eyes were full of water. They would turn him one way, then another. He was getting too close, so another sister made a drop in the river with a fast current; and another sister helped her, and they made deep ruts in the river. He went into the big deep falls, and the swift current, and he came out gasping for air. Each time he came up, the sisters would make another drop, and another one. Finally, he passed his target, the three women. He wondered what had gone wrong, but he got on the other side where it was smooth, and he thought, "Well, I guess I'm not supposed to have that." And that is how Celilo Falls was built.

as told by Umatilla Tribal Elder

The tribal council voted by a 2-to-1 margin not to accept the provisions of the Indian Reorganization Act. Tribal elders recall that farmers, ranchers and merchants in the area vigorously opposed the Indian Reorganization Act. The non-Indians claimed that the concept of IRA was communistic.
After ten more years of discussion the tribes were able to have lands restored to the Reservation. The Johnson Creek Restoration Act of 1939 , returned 14,140 acres of land to the Confederated Tribes. The 14,000 acres of 352,000 taken were returned to trust status through a series of Congressional actions aimed at improving the lot of Reservation Indians. World War II ended any appropriations through this act.

\section{ORGANIZING THE TRIBES}

Fishwheels and canneries did extensive damage to the fisheries and often inhibited or prevented the tribes' ability to fish. Hydroelectric and reclamation dams were being developed on the Columbia River, and irrigation practices drew so much water out of some tributaries that they barely supported life. Ancient usual and accustomed fishing locations along the river were becoming lost or useless. In the case of the Umatilla River, the salmon were made extinct by irrigation and reclamation efforts as early as $\mathbf{1 9 1 4}$. Meanwhile, local communities arrested Indians for fishing off the reservation or for "out-of-season" fishing when the Indians attempted to fish at their "usual and accustomed places," as was their right under the treaty. The tribes had to spend resources reaffirming and educating non-Indians about their rights. These, and other assaults on treatyreserved resources crucial for tribal survival, necessitated that the tribes become more directly involved managing affairs.

Beginning in 1947, a committee of tribal members was authorized to research ways by which the tribes could exercise more authority over their affairs. The committee sought Bureau of Indian Affairs (BIA) assistance. In 1949, a constitution and by-laws were adopted by a very close majority vote of the council. The establishment of the Constitution and By-Laws as the operating charter effectively brought to an end the power of the headsmen and recognized chiefs in the Tribal Council. From then on, we have been 


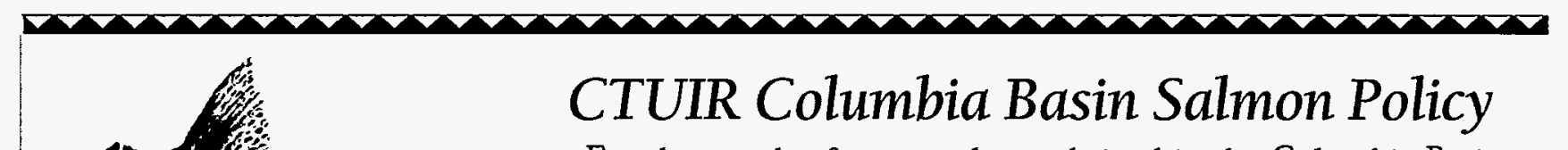

For thousands of years, salmon thrived in the Columbia Basin. Salmon always have been central to our religion and our culture, and we honored them accordingly. We had plenty of salmon to sustain us and plenty more to trade with others from far away.

In less than 150 years, the newcomers to our homeland have driven the once-plentiful salmon to the brink of extinction. Many salmon species already are gone forever.

It is not just the salmon that are endangered. Salmon are only a small symptom of a dying ecosystem. It is the Columbia Basin and the Pacific Ocean that are endangered. The salmon are telling us that the mountains, valleys, plains, rivers and ocean are all sick. Many other species now face extinction.

For thousands of years, we managed our resources with respect. This land was rich in natural resources when the first non-Indians arrived. The wasteful and disrespectful practices of the last 150 years have used up nearly all of these resources, creating ugly conflicts between those people now dependent on them.

These resources would be healthy if the Treaty of 1855 had been honored, and if the United States Government had honored its own laws. Salmon, sturgeon, eels and many other fish face certain extinction unless immediate and drastic changes are made in the human management of the Columbia Basin and the Ocean.

Salmon have been a source of sustenance, a gift of religion and a foundation of culture for our people since time immemorial. Their existence is vital and linked to ours. We will not allow them to go extinct.

We have the answers to this problem. We can save the salmon and make the economy of the Pacific Northwest even stronger at the same time. We must implement plans which meet not only our needs, but the needs of our grandchildren and their grandchildren.

A new energy plan, which would promote new economic development and which would significantly reduce the impacts of hydropower on the salmon, is needed and is possible. This new energy plan must be a critical component of our solutions.

It is time to heal the resources of this region. We call upon the other tribal nations, upon the people of the United States of America, and upon the people of Canada to support our policy: It is the policy of the Confederated Tribes of the Umatilla Indian Reservation that the health of the Columbia Basin and the Pacific Ocean be restored, and that all salmon and other native fish species be restored to the same population levels and to all rivers in which they lived prior to the treaty of 1855 . We hereby declare that a state of emergency exists in the Columbia Basin and Pacific ocean which requires immediate action.

A complete copy of the CTUIR's Columbia Basin Salmon Policy is available by contacting the Tribe's Public Information office at (541) 276-3165. Or write: P.O. Box 638, Pendleton, OR, 97801. Or email your request to croswell@ucinet.com

the Confederated Tribes of the Umatilla Indian Reservation (CTUIR), a confederation in the homeland of the Cayuse.

In 1950 , the first board of trustees began to identify ways in which they could improve the reservation and attend to the needs of the people. Financing for most tribal projects was attained through timber sales and other smaller sources of income. The concept of economic development was established through tribal resolutions aimed at resource management in timber, range and farming. 


\section{The Umatilla Basin Project: Water Issue Resolved Cooperatively}

Throughout the West, communities are facing conflicts over the reserved water rights of Indian tribes and the economic use of that same water by non-Indians. To tribes, this water is not only the basis of their economies, but also has significant religious and cultural importance. To irrigators, this water often is essential to their economies.

Under the Prior Appropriation Doctrine, a tribe's water right for purposes of its Reservation carries the date of the enabling treaty or executive order. The tribal water right for instream flows to protect a treaty-reserved fishery is "time immemorial." If these superior water rights were honored, existing water users would be significantly affected.

This type of conflict is usually addressed through an adjudication, which is administered by the state and which quantifies and recognizes all water rights within a basin. The litigation surrounding these conflicts typically takes two decades or more to resolve.

In the Umatilla Basin, the Bureau of Reclamation built a large irrigation project in the early part of this century. The irrigation economy was born and flourished, but the salmon were driven into extinction. The project de-watered the Umatilla River several months out of the year, and its dams blocked fish passage.

In the 1970's, this conflict became very heated in the Umatilla Basin. The Confederated Tribes of the Umatilla Indian Reservation and the irrigation districts, however, recognized that the conflict they faced was not of their own creation. The federal government, in promising the same water to the irrigators which it had a responsibility to protect for the tribes under the Treaty of 1855 , had pitted the tribes and irrigators against one another. Instead of fighting one another, the tribes and irrigators decided to focus on creating a solution.

The solution was the Umatilla Basin Project. This project was developed by the tribes, the irrigators, the Bureau of Reclamation, the Bonneville Power Administration, the Oregon Water Resources Department and the Oregon Department of Fish and Wildlife. Senator Mark Hatfield played an important role in helping the parties negotiate this solution, and in 1988 introduced legislation to authorize the project.

The Umatilla Basin Project is a water exchange that delivers Columbia River water to the participating irrigation districts. In exchange, the irrigation districts leave water in the Umatilla River for instream flows when it is needed for fish. In addition, a large portion of space in the McKay Reservoir is devoted for instream flow augmentation use. For every bucket of water taken from the Columbia River, a bucket flows back into it from the Umatilla River.

In 1951, the Umatilla Tribes directed its attorney to file a claim for lands ceded to the U.S. Government at the signing of the treaty of June 9 , 1855. The tribes contended that thousands of acres had been excluded from the reservation, and damages from the loss of fish and eel runs in the Umatilla River were also to be addressed in the courts. The Indian Claims Commission issued its final judgment in favor of the Confederated Tribes for an out-ofcourt settlement. This however was just the beginning of a long judicial process to address problems with the treaty negotiations of 1855 .
During 1953 , the tribe received $\$ 4,198,000$ from the United States for the loss of fishing sites at Celilo, Oregon that had been inundated by The Dalles Dam. All enrollees realized approximately $\$ 3,494.61$ in per capita payments. In addition, the U.S. Army Corps of Engineers agreed to construct 400 acres of fishing access sites to replace the ones inundated. The last Salmon Feast at Celilo was held in 1957. Other dams such as John Day Dam, McNary Dam and the dams on the Snake River continued to decimate the fisheries. 
The exchange includes three of the five major irrigation districts in the Umatilla Basin. While it does not increase flows year-round, it does increase flows during critical salmon migration periods in the spring and fall.

As a result, the salmon populations have gone from extinction a little over a decade ago, to dramatically increasing levels. Spring chinook, fall chinook and coho have been reintroduced using hatchery stocks. The remnant steelhead run has been augmented using hatchery techniques. Every year, salmon and steelhead return and spawn naturally in the Umatilla River, with an increasing number of naturally produced smolts as a result.

In 1996, over 2300 spring chinook adults returned to the Umatilla Basin. In comparison, only around 1600 spring chinook adults returned to the entire Snake Basin in 1995.

To complete the Umatilla Basin Project by including the remaining two irrigation districts, the tribes and the irrigators are working with Congress. In addition, the tribes and the City of Pendleton are developing a Joint Water Supply Project. This project will give the City of Pendleton a secure water supply for the present and the future, and will begin to address the tribes' onreservation water needs.

The Umatilla Basin Project serves as a model for how to resolve water conflicts peacefully and relatively inexpensively. Senator Hatfield, in his floor statement on July 24, 1996, introducing the "Umatilla Basin Project Completion Act," stated: "To date, the standard mode of operation has been protracted litigation and adjudication of rights, followed by construction of costly projects. In the Yakima River Basin, for example, the Federal Government and irrigators spent nearly 20 years and $\$ 50$ million just adjudicating the tribe's treaty fishery rights. Our experience in the Umatilla Basin, to date, has been more positive and successful."

Antone Minthorn, Chairman of the tribes' General Council and of the Tribal Water Committee, has been a leader in development of these cooperative solutions for over 15 years. He summarized why he believes that the Umatilla Basin Project has been so successful. "Our philosophy has been to negotiate rather than litigate. If necessary, we will litigate. But, we have seen that we can create solutions which meet everyone's needs by sitting down with our neighbors, listening to each other, and developing our own solutions."

For additional information, contact: Becky Hiers, CTUIR Natural Resources, at (541) 2763449.

In 1954, Congress enacted House Concurrent Resolution 108, known as the Termination Bill. The Termination Bill sought to end the federal government's trust relationship with the tribes. The government would liquidate tribal assets and return them to the tribes, withdrawing any official status from the tribes as sovereign nations. This new threat to tribal survival was vigorously opposed by the CTUIR. Accompanying the Termination Bill was the notorious Public Law 83-280. PL 280's purpose was to place the people under the state government for criminal and civil jurisdiction. Included in this law were provisions to turn maintenance of road systems over to state and county highway authorities, thus removing more trust land from the reservation. Public Law 280 was viewed by the federal and state governments as the initial in-road to terminating the reservation. Even though the tribes were not terminated, PL 280 was official policy until 1990.

A turning point for the CTUIR was the final results and decisions of the CTUIR's claims heard 
before the Indian Claims Commission. The decisions addressed issues of aboriginal use and lands controlled, claimed and compensated for by the treaty negotiations. The CTUIR had only been compensated for approximately 4.5 million acres as part of the 1855 Treaty Negotiations. The CTUIR Claim maintained that they in fact ceded 6.4 million acres. The country included lands in the John Day River Valley and lands in the Powder River Drainage. The CTUIR settled on the claim and were compensated.

Meanwhile, the damage to the fisheries resources led to the members of the CTUIR working with other lower Columbia River Tribes. In 1972, the Confederated Tribes and Bands of the Warm Springs of Oregon, the Confederated Bands of the Yakama Indian Reservation and the $\mathrm{Nez}$ Perce Tribe of Idaho created the Columbia River InterTribal Fish Commission (CRITFC) to deal with major issues on the Columbia River as they affected treaty related fisheries.

\section{SELF-DETERMINATION AT WORK}

The 1980s through the mid-1990s can be characterized as the visible beginnings and presence of self-determination efforts on the Umatilla Reservation. During this time there has been a substantial growth in Tribal programs, services, and enterprises, and building and capital improvements. Many of the planning initiatives and dreams of the 1960s and 1970s have become reality.

The tribes have contracted for, or assumed, a number of important economic, environmental, social and community programs that were provided before by the BIA or by other local, state and federal agencies. The number of tribal employees has grown to over 300 . Tribal enrollment grew to 1900 by the end of 1996 . By 1994 the tribal budget has grown to $\$ 11$ million from a budget of $\$ 1.5$ million in 1980. Land acquisition and restoration of the Reservation is a priority. The land base of the tribes has increased with acquisition of the 2,400 acre Conforth Ranch in western Umatilla County, as well as other smaller tracts on the Reservation.

In 1992 the Board of Trustees accepted a broad-reaching tribal-wide reorganization plan that established a departmental setting for tribal programs to be supervised by an executive director under the policy direction of the Board of Trustees. In 1994 the Plan was made effective with the strategic clustering of 15,000 square feet of new modular office and meeting space.

Impressive progress towards self-sufficiency has come with several successful economic development initiatives, including the $\$ 7.5$ million Wildhorse Gaming Resort, which employs over 330 persons. In 1992 the Board of Trustees adopted a Master Development Plan for the 600acre area north of the I-84 Interchange that will eventually include the Gaming Resort, Tamustalik Cultural Institute, a golf course, motel and RV park. The Farm Commission has contributed the $\$ 2.5$ million grain loading storage facilities and is taking the lead a native plant nursery operation.

An important success the CTUIR has had in establishing self sufficiency has been the establishment of an active and aggressive Department of Natural Resources. This department has evolved as a vehicle for providing an avenue for the tribes to work directly with land managers to protect and enhance natural and cultural resources. This program actively provides technical support for policy commissions and is directly involved in regulating significant tribal resources on and off the reservation. A major success has been the tribe's leadership in restoring salmon to the Umatilla river after 70 years of extinction.

Education has become a major issue on the Reservation today. The tribes are working to form partnerships to find ways to creatively educate, train and prepare Indian youth and young adults for the future. 
Today the CTUIR is taking a more active role in directly managing their own health care.

Although the tribes have made great strides, there are many monumental issues that they continue to tackle. The Columbia River fisheries are dwindling, the forests are sick, the water is polluted. Within the CTUIR aboriginal territories, the Hanford Nuclear Reservation remains the most polluted place in the Western Hemisphere. The tribes also continue to fight to maintain their sovereignty, and to protect their culture and religion. The tribes are heading into the 21 st Century poised with the organizational leadership and confidence, professional, technical, legal and economic resources to achieve a sustainable economy and cultural identity through selfdetermination. 


\section{WARM SPRINGS TRIBAL PROFILE}

\section{LOCATION AND LAND BASE}

The Warm Springs Reservation was established by treaty in 1855, and is located in north central Oregon. It is composed of a total of 646,000 square acres.

\section{TRIBAL ENROLLMENT}

3,582 enrolled members; approximately 3,200 resident on the reservation

\section{Native Language(s)}

Chinookan (Wasco); Sahaptin dialect (Warm Springs); Paiute dialect (Paiute)

\section{TRIBAL GOVERNMENT}

A tribal council consisting of eight elected members and the three hereditary chiefs of the tribes design policy and provide direction to the confederation's executive, including five general managers, four executive directors and a secretary-treasurer/chief operations officer.

\section{ECONOMIC BASE}

The primary job-producing enterprises are:

The Warm Springs Confederated Tribes main office The Warm Springs Forest Products Industries

The Warm Springs Sub-Assembly Plant

The Warm Springs Hydroelectric/

Power Enterprise Project

Kah-Nee-Ta Vacation Resort

Construction

Agriculture and range production

\section{BRANCHES}

Governmental Affairs and Planning

$553-3212$

Business and Economic Development:

Financial Services

$553-3468$

Human Resources

553-3217

Education Branch

553-3225

Public Information

553-3311

Public Safety

553-1338

Natural Resources

553-3284

Public Utilities

553-3548

Power Enterprises

553-3601

Kah-Nee-Ta Resort

553-1046

Warm Springs Museum:
$1800831-0100$

553-3331

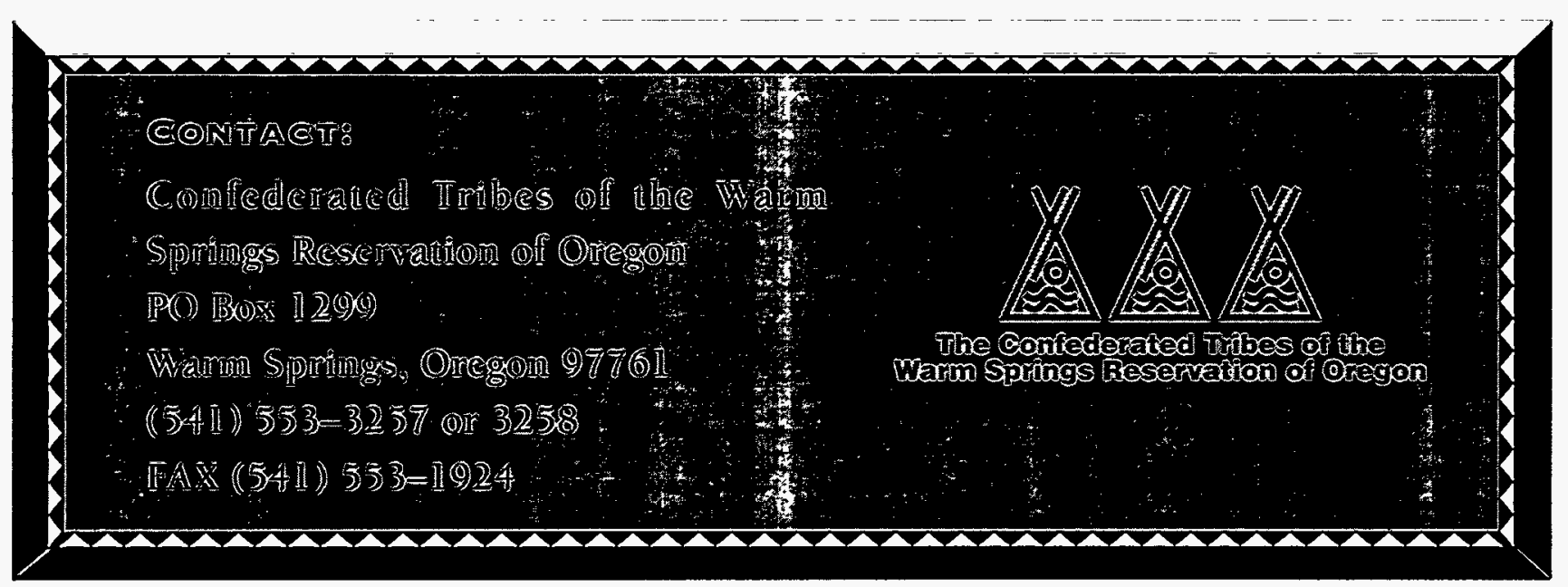




\section{Main NARRATIVE}

Three tribes make-up the Confederated Tribes of the Warm Springs Reservation of Oregon: the Warm Springs Tribe, the Wasco Tribe and the Northern Paiutes. In the time before the coming of Euro-Americans, these peoples were distinguished by location, language and cultural institutions, including spiritual, subsistence and political lifeways. At times their traditional areas and lifeways overlapped, at times not.

\section{TRADITIONAL CULTURE ( 11,000 BP):} LOCATION LANGUAGE, SUBSISTENCE, SPIRITUAL LIFE \& FAMILY, AND POLITICAL LIFE

....From the beginning of time our people have been religious people, and water was the most important thing in life. Water was the blood of life, like water is for Mother Nature. If water disappeared off this earth, we would not be here. We are here for thousands of years, three tribes

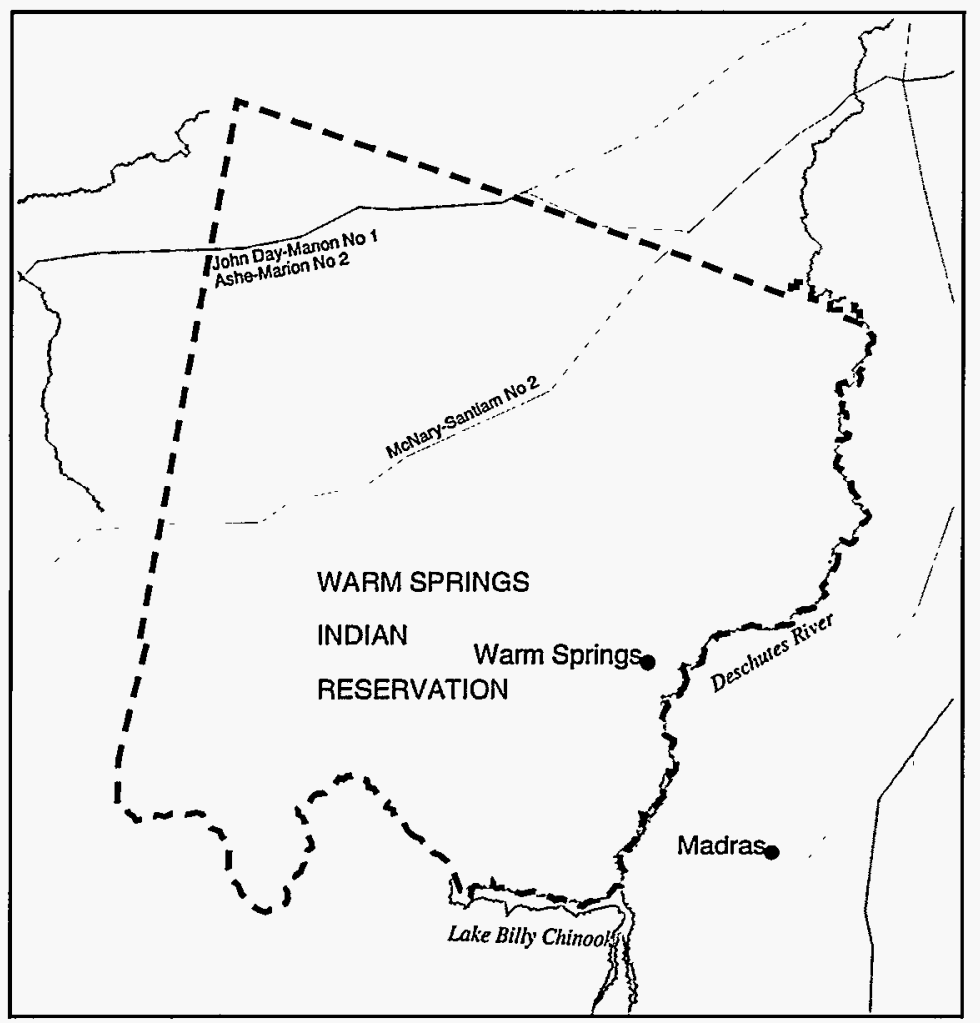

The ancestors of the present-day Warm Springs people concentrated mainly in three areas along the Columbia River. One group, the Tenino, lived at a narrow point in the river upstream of the present-day city of The Dalles; a second group, the Wyam, lived above Celilo Falls near the mouth of the Deschutes River; and a third group, the John Day, lived at the mouth of the John Day

River. A fourth group, the Tygh, lived in the Tygh Valley.

Downstream of Celilo Falls lived a tribe known now as the Wasco from the Chinookan word Wasqu, for their principal village. Unlike the ancestors of the Warm Springs, who moved inland away from the river in the winter, the Wasco lived on the river year-round.

The Warm Springs and the Wasco peoples were river people. Most of their spiritual existence and subsistence revolved around the Columbia River and its tributaries.

At the southernmost limit of the river people's seasonal travels were the Northern Paiutes. The Northern Paiutes' heartland was that portion of the vast Great Basin that lay in southeastern Oregon and northwestern Nevada. It is a semi-arid region ignored 
generally by white settlers, who found it inhospitable.

The bands of the Warm Springs Indians (Iciskin) spoke dialects of the Sahaptin language group, which they shared with other tribes throughout southeastern Washington, northeastern Oregon and central Idaho.

Meanwhile, the Wasco lived on the river year-round, and came to dominate a brisk intertribal trade on the Columbia. These people developed a jargon known as Chinook that was understood up and down the river, and eventually by Euro-American traders.

The Northern Paiutes, a Shoshonean people, spoke an Uto-Aztecan language linking them distantly with the Hopi of the Southwest and the ancient Aztecs of Mexico.

Both the Warm Springs and the Wascos took most of their food from the river, in the form of salmon. The salmon harvest season was the time of heaviest trading, with the Wascos and the Sahaptin-speakers performing the role of middlemen in a network that extended west to the coast, north into Canada, south into California, and east to the Rocky Mountains. Visitors from distant tribes camped with their hosts amid a festive atmosphere that included catching up on the news, sharing songs and dances, gambling and courting. Trading was a friendly but formalized activity often carried out between regular trading partners. Dried salmon and other fish products were the river people's stock in trade, which they used to obtain shells and roots from the west; baskets, beads, and blankets from the north; horses and buffalo hides from the east; and bows

\section{A Wascol Wishram carver made this bowl from the horn of a bighorn sheep.}

and obsidian arrows points, feathers, baskets and some slave trade from the south.

The Northern Paiutes shared a vague and shifting territorial boundary with the Warm Springs and Wasco peoples at about the same latitude as the present Warm Springs reservation. Skirmishes between hunting and gathering parties from the north and south were not uncommon.

Simply having enough to eat was cause for celebration for the Northern Paiutes, who named themselves after foods on which they most depended. In the territory now known as Oregon, there were such groups as the Wadadika (seedeaters) of the Harney Valley-Malheur Lake area, the Hunibuidika (root-eaters) to the north on the John Day River, and the Wadihichidika (juniperand deer-eaters) along the Deschutes and Crooked rivers in central Oregon. It was the Wadihichidika who the river tribes probably encountered most frequently, and it was in a corner of their territory that the Warm Springs Reservation was established.

The spiritual lives of the bands of the Warm Springs and the Wascos were inseparable from their daily routine. All beings, and inanimate objects as well, were assumed to have spirits or souls. The feasts were acknowledgment of those spirits in nature and the people's cooperative and symmetrical relationships with them. A measure of the people's integration with the natural world was their practice of adopting animal spirits as their guardians, internalizing particular animals' powers and protection to help them through life. At the age of six or older, a boy or girl was sent out on a spirit quest, a nighttime encounter with the natural and supernatural worlds, which could result in the accepting of a guardian animal spirit and its song. During the winter, people gathered for spirit dances, lasting several days at a time. At these ceremonies, people depicted their animal spirits in dance, to the sound of ritual singing and drumming. In this manner, others might become 
aware of the identity of a person's spirit, but not necessarily the nature of its powers.

Illness or death might result when a child's guardian spirit matured or became lost, or when one person's spirit entered another's body and battled with the host spirit. Then a shaman, who possessed many guardian spirits and therefore had much power at his disposal, might be called in to work on the victim. The shaman would draw out any intrusive or troublesome spirits, perhaps do battle with them himself, and either dispose of them or return them to the body where they belonged.

The natural world of the Northern Paiutes was as alive with spirits as that of the river people, but the powers associated with animals seemed to be the province of the shaman and not of each individual. Shamans were active dreamers who uncovered problems and found cures while in the dream state. Using such paraphernalia as eagle feathers and deer-hoof rattles, they cured physical or emotional ailments with singing, dancing and physical extraction of the offending spirit. They also controlled the weather and could be hired to "poison" a person.

The extended family within the Warm Springs and Wasco tribes was the basic economic and social unit. Marriages usually occurred between men and women and comparable social standing, and weddings involved long and ritualized gift exchanges between families. Men often took more than one wife, but there were taboos against adultery and incest.

The primary care of the children was the woman's responsibility, with grandmothers also assuming active roles. Often an individual outside the family would be invited to help in the preparation of children for adulthood, and at social or religious gatherings, children might be disciplined by a community "whipman." This communal aspect to child-rearing instilled in children the notion of respecting and listening carefully to all their elders, who had much to teach them about survival and ethics.

Each village had a headman, who was either descended from a headman or possessed special skills. Among the Wascos, wealth was also a factor, as measured by the amount of salmon stored away, or the number of wives or slaves. Villages were fairly independent, although there was acknowledgment of the common bond of culture, language and economy.

The Northern Paiutes, in their constant search for food, water and fuel, constructed only temporary homes. Their winter shelters were usually domed willow frames covered with mats of tule, cattail or sagebrush, and resting on top of the ground. In the warmer, more transient months, shelter was as basic as a mat-covered lean-to or simply a brush enclosure to deflect the wind.

Equally simple was the Paiutes' political and social organization. Because they had to cover so much ground to collect food and raw materials, the extended family was the most efficient grouping through most of the year. Ritual was spare as well among the Paiutes. Fathers held short, quiet ceremonies for their sons when they killed their first deer, and girls followed prescribed procedures when they first menstruated, including isolation. Courtship was rather perfunctory, and marriage itself even more so.

\section{Historical TIMES ( 1750 TO THE PRESENT)}

And so we lived, three tribes, following the food according to the season, trading at Celilo and giving thanks. Then the white man came, trading, bringing new things to eat and use. We liked the coffee, the sugar, the tradecloth and especially the beads. But for their trade, the settlers demanded a terrible price - the land between the mountains and beside the river. Their strength in numbers 
left us no other choice. We did reserve land for ourselves with mountains, water, food and sacred ground. But the rest was ceded to the United States Government. On June 25th, 1855, the Warm Springs and Wasco left thousands of years of tradition and began a new way of life. They were joined twenty years later by the Northern Paiutes. The agency was built, a school, a store, a church; our peoples' way was condemned....

Sporadic contact occurred between European and American traders from the coast and the river people from the 17 th century. As long as the contacts revolved around commerce, problems were mostly limited to the spread of disease from the newcomers to the river peoples. Between 1750 and 1800 imported European diseases had reduced their original ten thousand population to about two thousand.

However, widespread American overland exploration and settlement followed the Lewis and Clark Expedition of 1804 to 1806 . Once settlers began arriving, there was constant contention over land and resources. The discovery of gold in the western United States, the call for a transcontinental railroad and the perception that its citizens needed protection from the western tribes led the United States Government into a

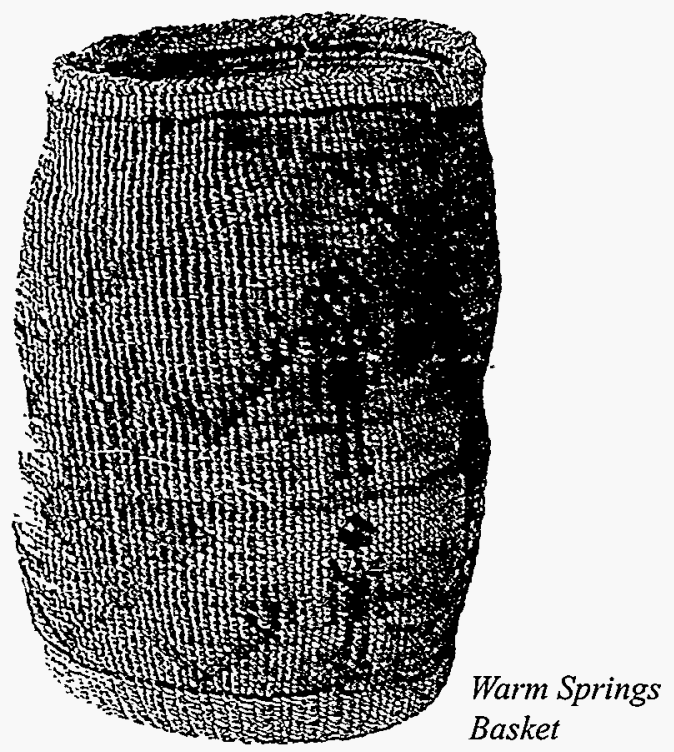

round of treaty-making at the mid-point of the 19 th century

On June 25, 1855, four years before the Oregon Territory earned its statehood, General Joel Palmer, the territory's superintendent of Indian affairs, gathered an arbitrary representation of the Columbia River tribes and bands under an oak tree in Wasco. Palmer's mission was to clear the way for the final limits of the westward expansion, securing incoming homesteaders from Indian attacks.

It was not unusual during treaty-making for white negotiators to arbitrarily identify and define tribal groups, and to designate as their opposites tribal negotiators with whom the whites felt they could most easily deal. For purposes of the 1855 treaty, Palmer dubbed the river people "Wasco" and "Warm Springs." He urged the group to sign a treaty ceding their 10-million acre habitation in exchange for a 600,000 acre reservation a hundred miles south of their Columbia homelands. Palmer offered incentives of $\$ 150,000$ in cash, and promises of farm equipment and a newly constructed town, complete with white tradesmen who would teach their skills to native apprentices. The Wascos and Warm Springs signed.

The Warm Springs Reservation, like other Indian reservations, was not granted by the government; rather it was retained by the treaty tribes as part of their aboriginal territory.

By 1859 , all except for a few holdouts had moved to the new reservation. Although their adopted territory was mostly unfamiliar to them, the Indians were mollified by a treaty provision that guaranteed them the right to continue to draw food from "all of the usual and accustomed stations," including their old salmon fisheries on the Columbia River. No provisions had been made, however, for the event that these "usual and accustomed stations" would belong to white landowners, who couldn't abide natives on their riverfront property. White settlers balked at Indians crossing their lands to hunt and fish. A 
supplemental treaty drawn up in 1865 soothed the settlers with a stipulation that Indians could not leave the Warm Springs Reservation without a permit. Their new home had become a prison camp. The treaty of ' 65 was never successfully enforced and is considered fraudulent.

The whole relationship of the river people to the land was altered when the reservation was established. Not only did they have to transfer their allegiance to a parcel of land that figured little into their culture, history and accustomed lifestyle, they also had to learn new ways of inhabiting and using their land. Indians throughout North America made little distinction between themselves and the natural world; humans, animals, plants and the soil itself had spirits that interacted as part of a harmonious whole and had a place. The land could be used, with proper displays of respect and gratefulness, but it never occurred to the native people that it could be owned.

The treaty of 1855 and subsequent laws and court decisions changed all that. It was an erroneous but convenient assumption on the part of the United States that the Indians held "title" to the territory they inhabited. Once this relationship was described in European, legalistic terms, it could be extinguished.

Meanwhile, a band of Northern Paiutes led by Chief Paulina, went to war against the United States government to protect their way of life. Defeated and imprisoned, a remnant of 38 Paiutes in the autumn of 1879, were carried to Warm Springs from Fort Vancouver as prisoners of war. These 38 formed the nucleus of the Northern Paiute population that came to live on the Warm Springs Reservation.

\section{THE PRESENT AND FUtURE}

The struggle for the three tribes in the intervening century has been to organize themselves into a people that at once retained their ancient tribal identities, but lived as one.

\section{Speaking with Delbert Frank, Elder}

Portland General Electric came here and proposed to build a dam, the Pelton Dam. It was a water rights case because the reservation line is in the middle of the river, but it doesn't say how much water is separated by the middle of the river marker. The people said, "How about the salmon on the other half of the river?, "because we reserved all of that on the bordering streams, through and bordering streams. We reserved all fish. The treaty rights still stand today. We reserved all the food in the bordering stream, even though the reservation line may be on the land itself. We reserved the rights to all that water - the Deschutes River, half of that and all the other streams. The state and federal government went to lawsuits - it was the famous Pelton Dam case - and went from the federal court of appeals to the U.S. Supreme Court. I was the originator of the case, when I went to work for the tribe as a councilman. I joined the council in 1956. Before that I lived like anyone else. I lived the old traditional way. There was no employment, the sawmill wasn't there. I lived through the Depression days. It didn't bother me much, because we still had all the deer, and salmon and trout and whatever else.

I lived around here all my life. Lived like a true Indian boy by fishing and hunting, and whatever else. No other people but Indians live on this reservation. Still practice the old religion. That's the religion the laws are based on. In fact, the words in them songs are the law. All the songs got words in our language.

I went to school in 1930. I went to government school, which was the only school. I went through high school right here in Warm Springs. I went into the service when I was seventeen, and I couldn't even vote yet. I came out four years later and I still couldn't vote. Our job was hauling the troops and landing them. I went ashore on all the landings, quite a few. There were some big islands and some

(continued next page) 
Speaking with Delbert Frank, Elder (cont.)

small islands. Iwo Jima was only eight miles around, but it was a major transportation area for the Japanese.

We built a landing strip there. B17s were the only ones that could come in at first. If you chose to be a gunner on a B17, you knew what you were getting into. Pretty hard to talk about it sometimes when I'd sit down with those guys at night. They'd sweat it out thinking about what would happen. The flyers were young kids, 18 or 19. I'd feel sorry for them, almost talking to themselves. I'd see their mouths moving around. Golly, they knew what they got into. But that was the kind of men that won the war.

It wasn't a shock to get off the reservation. My old people used to tell me what was coming. They already knew what was coming. They were wise, smart old people. Fourteen years before I graduated from high school, my great grandparents told me that there was going to be a big war. I knew when I took off I was going to get in trouble. But my brothers said, "If we don't go, who's going to win the war?"

I fished at Celilo Falls, and I followed the spring salmon to Sherar's bridge. I had fishing sites there. The old traditional way of the Indian fishing site began in the beginning of time. An Indian found a fishing site where you could catch fish, because it wasn't just any place, but certain turns or eddies that go ten feet down and there's a change of current, you could stick a net down there.

We would catch all the fish we could and give it away to old people. The time to catch them is in the evening, when the shadows are created by the hills. That's when the fishing is best. We fished with anything: fly, bait, worms. We cleaned them up and put them in burlap sacks, cover them with leaves and sprinkle water on them. Now we got a crew that does nothing but salmon fishing on the Columbia River, from Cascade Locks, wherever there's an eddy, where the water's deep and the currents right. We store them away in a locker until a funeral goes on.

(continued next page)
The land itself was helpful, familiar in its timbered, mountainous, well-watered form, although the terms of living on the land and drawing sustanance from it would be forever different. Even as the three peoples continued to dig for roots, fish the rivers, and hunt the mountains in the accustomed ways guaranteed to them under the treaty, they attempted to learn farming. It was also the policy of the federal government to teach them how to farm as a means toward assimilation. They succeeded in combining their traditional religious and subsistence patterns with the new ways largely because they remained one of reservations most isolated from encroachment by whites. Not until the 1920s was there even a major road cut into reservation lands. Until that time, many families continued to live in tipis, usually out of choice, although construction materials and training promised under the treaty and later often either never materialized, or was substandard.

In 1934, the Federal Indian Reorganization

Act ushered in a new era for the three tribes. It put a stop to the allotment of surplus Indian land to settlers that had occured under the Allotment Act of 1887 , returning unallotted land to the tribes and appropriating funds for development on reservations to tribes that organized their governments into corporations. Many tribes, the Warm Springs included, were suspicious of the offer and slow to reorganize, particularly because reorganization meant an end to traditional leadership patterns. Still, in 1938, the Warm Springs tribes took the government up on its offer, forming a tribal council of eight members, under the direction of the general council, which included every voting-age member of the tribes. The Warm Springs tribes retained traditional leadership as much as possible under the reorganization, with the three traditional chiefs serving on the council alongside eight elected members. The tribal council held information fairs on a yearly - or more often - basis, infoming tribal members of issues, and taking direction from them 
through the general council. In the early 1990s, the tribal government was again reorganized under the same policy-making bodies of the tribal and general councils, but adding a layer of professional managers, most of them tribal members.

This strong, responsive government husbanded the economic growth that began with the award by the federal government to the tribes of $\$ 4$ million dollars in 1957 for loss of their fish and water resources due to the construction of The Dalles Dam. The dam drowned the traditional fishery at Celilo Falls as the people stood on the banks and wept. While no amount of money could ever replace the cultural and spiritual significance of the Falls, the award at least provided seed money for a number of tribal enterprises. The growth that flowered from the award blossomed eventually into what is now considered a model of modern tribal economic development. The first thing the tribal council did on receiving the award was to commission a comprehensive study of tribal resources.

Shortly after the completion of the comprehensive study, the Confederated Tribes paid $\$ 165,000$ to recover land at Hot Springs on the reservation that had been sold to an outsider. This became the site of a resort, Kah-Nee-Ta Lodge. Over the years, the lodge has grown in its number of rooms, as well as adding a convention center and an 18 hole golf course.

On August 19th, 1966, eligible voting members of the tribes approved a $\$ 15$ million referendum that forever changed the way the tribe handled its bountiful timber resource. What the tribe gained through the approval of the referendum was the right to process their own timber with their own wood products complex, now known as the Warm Springs Forest Products Industries. On April 12, 1967, the tribe purchased the Warms Springs Lumber Company, built in 1943 , for $\$ 1.25$ million. For an additional $\$ 1.95$ million, the tribe purchased plywood and veneer
Speaking with Delbert Frank, Elder (cont.)

We'll use 300 lbs. for a funeral. We just had two funerals. When there's a giveaway, the family gives away a lot of valuable things.

My family traveled all over central Oregon and into the high Cascades, gathering huckleberries by Zig Zag and Welches. We left our wagons there by the old post office in Welches. If you go upstream there's a bridge there, and a trail that went up to the top of the hill. You go up to Stony Camp, in that direction. Used to be all huckleberries. It burned one time way back in the early twenties. It was all brush, and huckleberries were sticking up plain. Now big trees, and no more huckleberries.

I'm a board member of the museum. It was my first development idea. Old people wanted history. Nobody could tell the history, they were afraid that one of them would tell the wrong story and get in trouble.

We came from The Dalles country, from Tenino country by Celilo Falls. That used to be our country. My great-grandmother remembered; she died when she was a 114 years old. Another grandmother from the other side of the family died when she was 111 years old. My great grandmother told me when she had a vision - her family were very religious people. She seen a people coming down, light complected, blue eyes, red hair...they came from that direction in a canoe.

I fished in Celilo Falls for 27 years until The Dalles Dam went in. Fished with dip nets, set nets. We'd even hook them. Chief Tommy Thompson, when he saw Bonneville Dam first go in, he says they didn't negotiate. The Indian people was under the Department of War at that time, and they [the Department of War] could do what they wanted. The Warm Springs Tribe never went to war with the U.S. Army, and we reserved our sovereign rights. But the U.S. Government has a trust responsibility, and they have to put up the money to manage the resources. For everybody, not just Indian. 


\section{Tribal Sovereignty}

ULTIMATE SOVEREIGNTY IS VESTED IN THE PEOPLE, WHO RECEIVED THAT SOVEREIGN AUTHORITY IN THE FORM OF LAWS GIVEN BY THE CREATOR AND BY THE LAND ITSELF. OUR PEOPLE HAVE DELEGATED ONLY LIMITED AUTHORITY TO THE TRIBAL COUNCIL AND HAVE RESERVED THE REST OF OUR NATIONAL SOVEREIGNTY TO OURSELVES.

THE CONFEDERATED TRIBES SHALL ALWAYS EXERCISE OUR SACRED NATIONAL SOVEREIGNTY IN ORDER TO ACHIEVE THE HIGHEST OF ALL GOALS: TO PRESERVE OUR TRADITIONAL CULTURAL WAYS THAT HAVE EXISTED FOR SO FROM TIME IMMEMORIAL IN HARMONY WITH OUR HOMELAND; AND TO PROVIDE FOR THE WELLBEING OF OUR PEOPLE FOR THE MANY CENTURIES THAT LIE AHEAD. WE SHALL, AS WE ALWAYS HAVE, LIVE IN BALANCE WITH THE LAND AND NEVER USE MORE OF OUR PRECIOUS NATURAL RESOURCES THAN CAN BE SUSTAINED FOREVER. WE SHALL, AS WE ALWAYS HAVE, GIVE RESPECT TO ALL PERSONS; ACKNOWLEDGE THE SPECIAL WISDOM OF OUR ELDERS AND RELIGIOUS LEADERS; NURTURE THE BRIGHT HOPES FOR THE FUTURE THAT RESIDE WITHIN OUR YOUNG PEOPLE; AND ACCEPT FULL PERSONAL RESPONSIBILITY FOR ALL OR OUR ACTIONS, AS OUR BASIC RELIGIOUS TEACHING IS THAT WE ARE FULLY ACCOUNTABLE TO THE CREATOR FOR OUR CONDUCT.

TODAY THE ANCIENT SPIRIT OF THE CREATOR STILL DWELLS IN ALL THE PLACES OF OUR HOMELAND, AS IT ALWAYS HAS AND ALWAYS WILL. OUR NATIONAL SOVEREIGNTY PROTECTS THAT SPIRIT, OUR LAND AND WATERS, OUR PEOPLE, AND OUR VIBRANT CULTURE, RELIGION AND LANGUAGE....

....WE, THE MEMBERS OF THE CONFEDERATED TRIBES OF THE WARM SPRINGS RESERVATION OF OREGON, COMPRISED OF THE WASCO, WARM SPRINGS, AND NORTHERN PAIUTE TRIBES, HEREBY DECLARE OUR NATIONAL SOVEREIGNTY. WE DECLARE THE EXISTENCE OF THIS INHERENT SOVEREIGN AUTHORITY - THE ABSOLUTE RIGHT TO GOVERN, TO DETERMINE OUR DESTINY, AND TO CONTROL ALL PERSONS, LAND, WATER, RESOURCES AND ACTIVITIES, FREE OF ALL OUTSIDE INTERFERENCE - THROUGHOUT OUR HOMELAND AND OVER ALL OUR RIGHTS, PROPERTY, AND PEOPLE, WHEREVER LOCATED.

THE GEOGRAPHIC REACH OF OUR SOVEREIGNTY INCLUDES THE WHOLE AREA WITHIN THE BORDERS OF OUR TRIBAL RESERVATION, RESERVED BY THE WARM SPRINGS AND WASCO TRIBES IN THEIR 1855 TREATY WITH THE UNITED STATES....

....OUR HOMELAND ALSO ENCOMPASSES, AND OUR SOVEREIGNTY EXTENDS TO, TRIBAL OFF-RESERVATION RIGHTS IN OUR HISTORIC ANCESTRAL DOMAIN, A VAST REGION THAT INCLUDES THE COLUMBIA PLATEAU AND FAR BEYOND. THESE OFF-RESERVATION RIGHTS INCLUDE RIGHTS ATTACHING TO OUR USUAL AND ACCUSTOMED FISHING GROUNDS AND STATIONS; TO IN-LIEU FISHING SITES; TO BURIAL SITES AND OTHER SACRED SITES; TO LANDS ON WHICH TRIBAL MEMBERS CAN HUNT, GATHER ROOTS AND BERRIES, AND PASTURE STOCK; TO ACQUIRED LANDS; AND TO OTHER AREAS OVER WHICH OUR TRIBES NOW POSSESS, OR MAY LATER ESTABLISH, RIGHTS OF ANY KINDS.

OUR PEOPLE, AS THE CUSTODIANS OF OUR SOVEREIGNTY, REVERE ALL OF THOSE THINGS AND DECLARE THAT THEY SHALL BE PROTECTED ABSOLUTELY AND FOREVER.

From the Declaration of Sovereignty, Confederated Tribes of the Warm Springs Reservation of Oregon 
equipment. The entire $\$ 3.2$ million debt was repaid within the first five years of operation.

Other tribal holdings include a fish hatchery that releases nearly a million salmon smolts a year into the Columbia River; fees from Portland General Electric for the Pelton Dam, located on the reservation; and several small businesses under the umbrella of the Business and Economic Development branch of tribal government. These various ventures provide jobs for a growing number of tribal members and revenues for the tribe. Also, in 1992, the Warm Springs Tribal Council became the first tribal body to offer taxexempt, full-faith and credit type bonds to private and institutional investors. These bonds have since funded a number of tribal programs, such as the construction of the Early Childhood Center, and construction of the Health and Wellness Center.

Warm Springs holdings sprawl over five counties, bounded by the Cascades to the west, the Deschutes River to the east, and the Metolius River to the south. The reservation's northern border has recently been extended to encompass a legal slice of land called the McQuinn Strip, reaquired by the tribes after a century-long dispute. The McQuinn Strip adds over 61,000 acres to the reservation for a total of more than 600,000 acres, or close to 1,000 square miles.

Even as economic development escalates, however, the tribes are determined to confine growth within the limits of their cultural values. When the council considered building a ski resort on its land on $11,000 \mathrm{ft}$. Mt. Jefferson, a tribal referendum killed the plan. All resource management is conducted according to the values of respect for the earth, and preservation of the resource - and the value of respect for the earth for future generations.

This concept of looking to the past for cues as to how to manage the future is why preserving the culture has taken on paramount importance. Many tribal members continue to practice traditional Indian religions such as sweatlodge and Washat, feasting during the gathering of first foods every year, and conducting giveaways during funerals of tribal members. One of the initial proposals following the comprehensive study in the late 1950s was for funding of a tribal museum. In 1993, the Museum at Warm Springs opened its doors, following the approval by the tribal council in 1988 of $\$ 2.5$ million for its construction...the largest financial commitment of any tribe to such a museum.

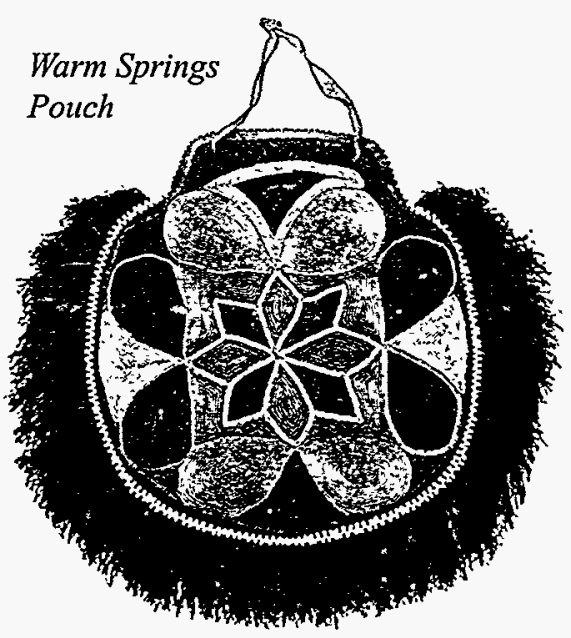




\section{Resource Management for the Ages}

Generations of Native Americans have developed lifestyles, cultures, religious beliefs and customs around their relationship with fish, wildlife, and the plant communities natural and renewable resources. Historically, these resources provided food, shelter, clothing, and tools, and were traded for a variety of goods.

They still continue to provide a base of sustenance, cultural enrichment and economic support for many tribes, and help maintain tribal structure and stability by permitting employment in traditional and desirable occupations.

All animals and plants were so important to the Native Americans that they were reserved within most tribes' representative treaty with the U.S. Government. They are named in the songs during tribal religious ceremonies and are utilized during this period of time. Most elders of the tribes were raised on these specific foods and have no desire for the modern day foods that are available in the marketplace. These reserved treaty rights are used by the tribes to protect all of these valuable resources.

The people who inhabited this continent prior to the discovery by outsiders, lived close to and in harmony with nature. Most, if not all, felt that they were a part of the "Web of Life" that binds everything together. Every living plant and animal depended on some other organism for their own survival. That is the reason we the people never wasted any resources, and took only what we needed, and used it wisely.

Mother Nature knows what she is doing and does the best job. Through natural processes the natural resources will take care of themselves since they have been adapting to changes for a long time. Natural processes are upset by man in his quest to improve conditions for himself and he does not realize the damages created by too fast of a change in a short period of time. Man never realizes the chain reaction of damage to other resources caused by over-exploitation rates of a single resource. When man recognizes that he is responsible for damages to the environment, he feels obligated to fix it even if he really does not know what he is doing.

Water is of the most important natural resources since every living plant and animal depend on it for survival. Yet water is one of the most misused and abused natural resources. Its ability to self-purify is changed through pollution, changing its natural course, changing its banks and riparian areas through construction of dikes and riprap to protect against flooding, construction of dams which eliminate natural flooding that aids in cleansing streambeds, just to name a few.

Managing the natural resources similar to what occurs natural would be best in the long term. Putting unnatural structures, barriers, non-resident plant and animals in an area where they are not found historically can create different changes to that specific environment. In other words, don't try to fool with Mother Nature.

\section{Present Management Practices and Strategies}

With the philosophy of "all things are connected," the Confederated Tribes of the Warm Springs have adopted and implemented an Integrated Resource Management Plan (IRMP). All resource operations are reviewed by a team of professionals from various resource departments to ensure that any proposed management action has minimum impacts on other natural resources. This is to ensure the long-term productivity of all natural resources. 
Years ago, the tribal leaders recognized the need and importance of planning for the future. At that time they initiated the development of a Warm Springs Reservation Comprehensive Plan. Once the plan was completed by the consultants and adopted by the Tribal Council Resolution, the framework for carrying out plan policies and achieving tribal missions was set in motion. The Comprehensive Plan establishes overall tribal missions for 20 year periods relating to land use management practices. When the plan was revised it also included the human development direction.

Two of the goals within the Comprehensive Plan are: (1) to utilize the natural resources of the reservation in the best interest of the members of the Confederated Tribes; and (2) to recognize an obligation to future generations in the management of the natural resources of the reservation.

Intergovernmental agreements between the Confederated Tribes of the Warm Springs, federal agencies, and states or their political subdivisions are recognized tools for addressing issues and concerns for shared resource management. Other off-reservation activities include participation in a variety of national, international, and state and inter-tribal organizations or forums that manage natural resources.

\section{In Conclusion}

With the coming of the new people to this land, people with a different view of philosophies and beliefs, the unbalancing of nature started and will continue until they realize, as a body of people, the importance of interdependence of natural resources on one another. Plants and animals are cyclic and go up and down based on environmental factors.

To destroy natural resources beyond the point of recovery is not the Native American way. Remember, our people understood the importance of living in harmony with nature since you did not destroy what you depend on for survival.

We cannot push back the time clock or go back to the past, but we can play a vital role in protecting what we have at the present. What we do now in preserving natural resources will benefit our people in the future.

If we can manage the resources by using common sense and not have politics manage as they have in the past, the natural resources of the future should have a chance for continued survival.

As stated earlier, tribal people believe in the natural way. If we can mimic nature or put salmon back into natural production and protect their habitat, we would be better off in the long-term. Artificial production of salmon has its role, but it cannot be used to replace natural production.

Through balancing of economics and natural resource utilization and protection, it is possible to have a win-win situation. Once this balance shifts, everything and everybody suffers from created impacts.

Through cooperative efforts by the people of the Northwest, we can develop strategies for natural resource management that will be beneficial for everyone.

Eugene Green, Tribal Resource Manager 


\section{YAKIMA TRIBAL PROFILE}

\section{LOCATION AND LAND BASE}

The Yakama Indian Nation is a treaty nation made up of 14 tribes that signed the treaty of 1855 at the Walla Walla treaty grounds. The treaty reserved an original portion of their homeland totaling 1.3 million acres in the south-central part of Washington state. The nation ceded over 12 million acres during those peaceful negotiations and provided treaty rights on those ceded lands outside the reservation.

\section{TRIBAL ENROLLMENT}

8,500 enrolled members

\section{NATIVE LANGUAGE(S)}

Dialects of Sahaptin language family

\section{TRIBAL GOVERNMENT}

Government affairs are run through a committee system, which reports directly to the tribal council. Representatives to the tribal council are elected to four-year terms by the general council, composed of all enrolled tribal members over the age of 18 years.

\section{ECONOMIC BASE}

\section{Resources}

Timber - 309,000 acres in commercial timber Agriculture - 27,000 acres of irrigated acreage, mostly in alfalfa hay, wheat, hops, apples, pasture, sweet corn and grain corn.

Rangeland - 938,358 acres in grazing

Labor - 3,900 people in the workforce, of which 1,690 are classified as being in construction, and skilled and general labor fields

\section{Existing Industry}

Timber, fisheries, tourism, tribal land enterprise, tribal credit enterprise, Wapato Industrial Park

\section{Projects in Development}

Forest Product Processing Facility, retail outlet, entertainment establishment

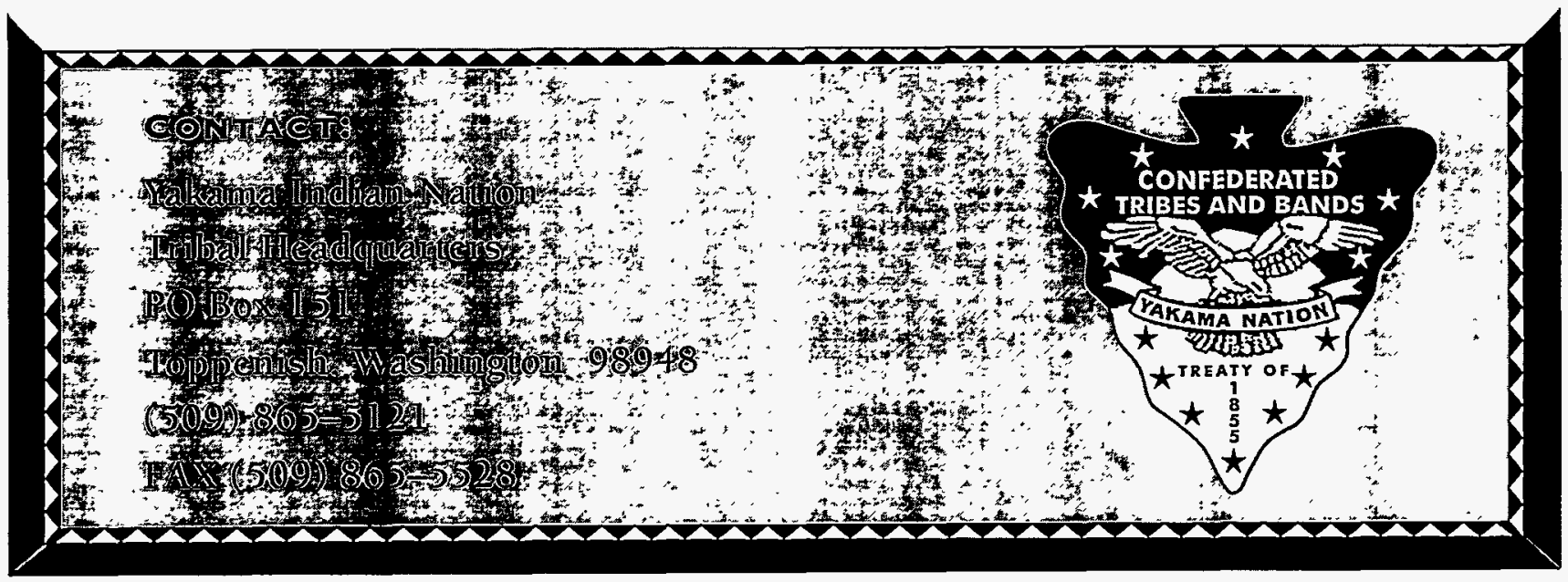


STANDing COMMITTEES (CALl and Request extension)

Timber, Grazing, Overall Economic Development

Committee

Fish, Wildlife, and Law and Order Committee

Loan, Extension, Education and

Housing Committee

Health, Employment, Welfare Recreation,

Youth Activities

Roads, Irrigation, and Land Committee

Enrollment Committee

Legislative Committee

Budget and Finance Committee

SPECIAL COMMITTEES (CALL AND REQUEST EXTENSION):

Tax Committee

Immigration Committee

Public Relations/Media Committee

Cultural Committee

Radioactive/Hazardous Waste Committee

Heritage Center Committee

Timber, Fish and Wildlife Committee 


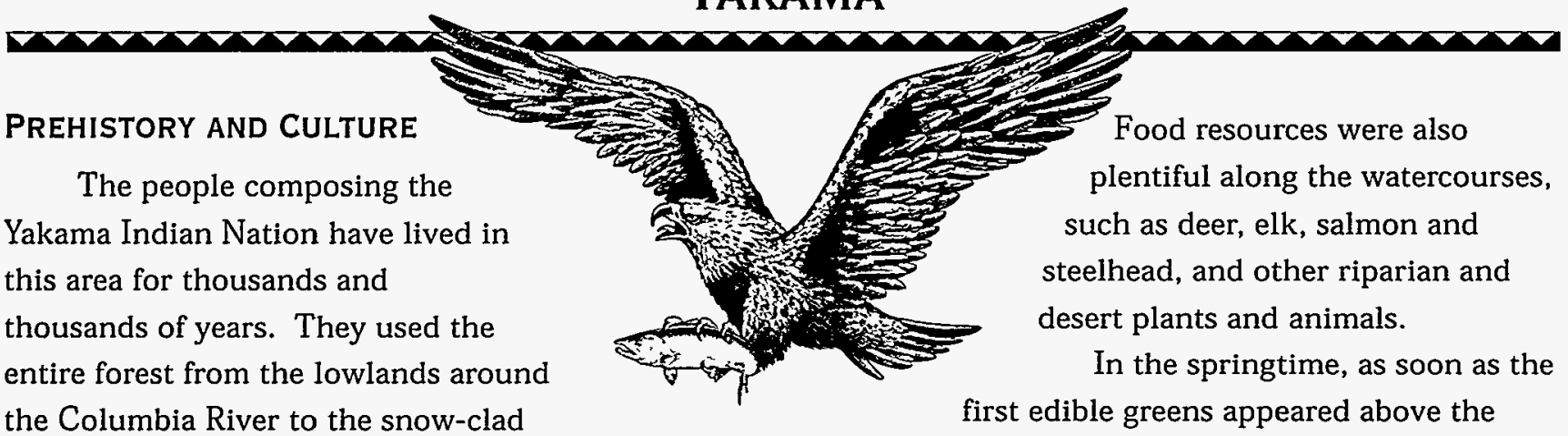

the Columbia River to the snow-clad

Cascade Mountains. Known locally as the

"Taptail" or "Wap-tail-min," the Yakama name

meaning a "narrow river people" may refer to the

narrows in the Yakima River at Union Gap where a large Indian village was located in the past. One of the first whites to visit the area, Alexander Ross, a Canadian pioneer, fur trader and author whose writing includes some of the first detailed accounts of the territory, described an Indian encampment while on a horse-buying trip to the Kittitas in 1814 for the Northwest Company at Fort Okanogan: "It extended six miles in every direction, and containing not less than 3,000 men, exclusive of women and children, and triple that number of horses, a very imposing sight."

People spent the coldest months in winter villages that were generally located on the valley floor, a place with a relatively moderate climate. Reliable sources of wood and water, and protection from cold winds, could be found there.

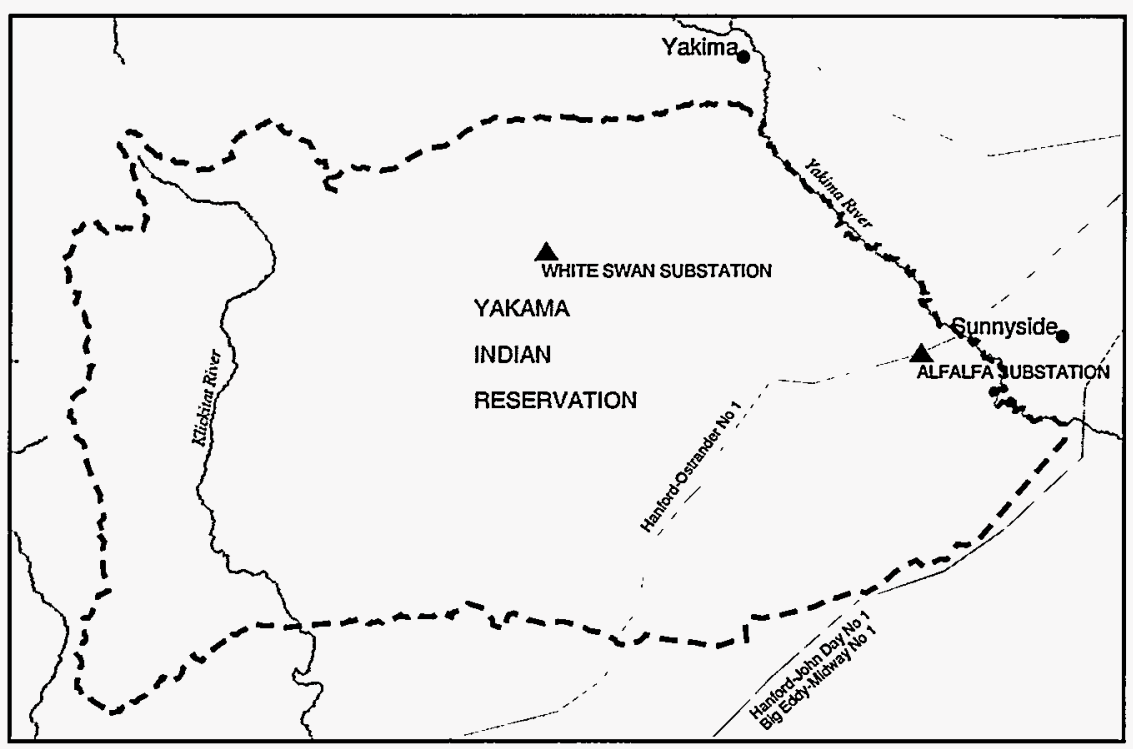

ground, people began preparing to move across the countryside in search of fresh food. The melting snows would be followed upslope, and edible roots would be collected as they matured. Some people would go to the rivers to fish. Others would remain in the mountains following the maturing plants upslope, ending with the huckleberry harvest in the fall. At that time, foods would be either stored or transported back to the winter village from both the mountains and the rivers, and people would settle in once more, living on stored foods and occasional fresh meat until the next spring.

The valley floor looked much different prior to the signing of the treaty of 1855 than it does today. The valley was wet in many places, covered with stream meanders, oxbow sloughs and wetlands, of both perennial and seasonal nature. Each watercourse supported groves of oaks and cottonwoods, and each had a riparian corridor that hosted a variety of plants, waterfowl, and four-legged animals. It was possible for a person to canoe from White Swan to the Yakima River without ever using Toppenish Creek - something that would be impossible today. The drier areas were covered with grasses, and mixed in with the grasses were sagebrush. Today, for the most part, only the sagebrush remains.

The Yakama then and now believe every rock and tree of their homeland, every stream and lake, animal and bird - all things - are 
imbued with spirit: their land literally was alive to them, not dead matter. All that exists - not just humans, animals and plants but rock, water and air - is alive and sacred. From our place among the beings of the world, the traditional Yakama seek to maintain relationships with everything that is alive. These relationships must be in order: for as these beings are sacred, so these relationships are sacred. Something is sacred only when it is in its proper place. It could even be said that being in their places is what makes them sacred, for if they are taken out of their place, even in thought, the entire order of the universe would be destroyed. Sacred objects therefore contribute to the maintenance of order in the universe by occupying the places allocated to them. To occupy our own place in a correct proportion and balance to the rest of creation is central to Yakama spirituality. To place ourselves above other life would be presumptuous and violate Yakama cultural and spiritual ideals of generosity and hospitality. Life, land and water are the cultural spiritual resources to the Yakama People.

The Yakama People's relationship to the land is indicative of this respect. The Earth is everyone's mother. She supports all life: from her all the people - salmon, roots, berries, humans take their sustenance. The people's relationship to the earth must always be one of recognition of their interdependence. The proper balance must be nourished and renewed between people and the continuing creation of the earth. It is inconceivable to traditional Yakama to "own" their mother. Rather, the human people see themselves as a living part of the living whole.

\section{HISTORY}

In 1842, the Oregon Trail reached the Willamette Valley and opened the floodgates for hordes of immigrants from the east. As more and more white people settled in the Yakama country, the clash of two different cultures escalated into

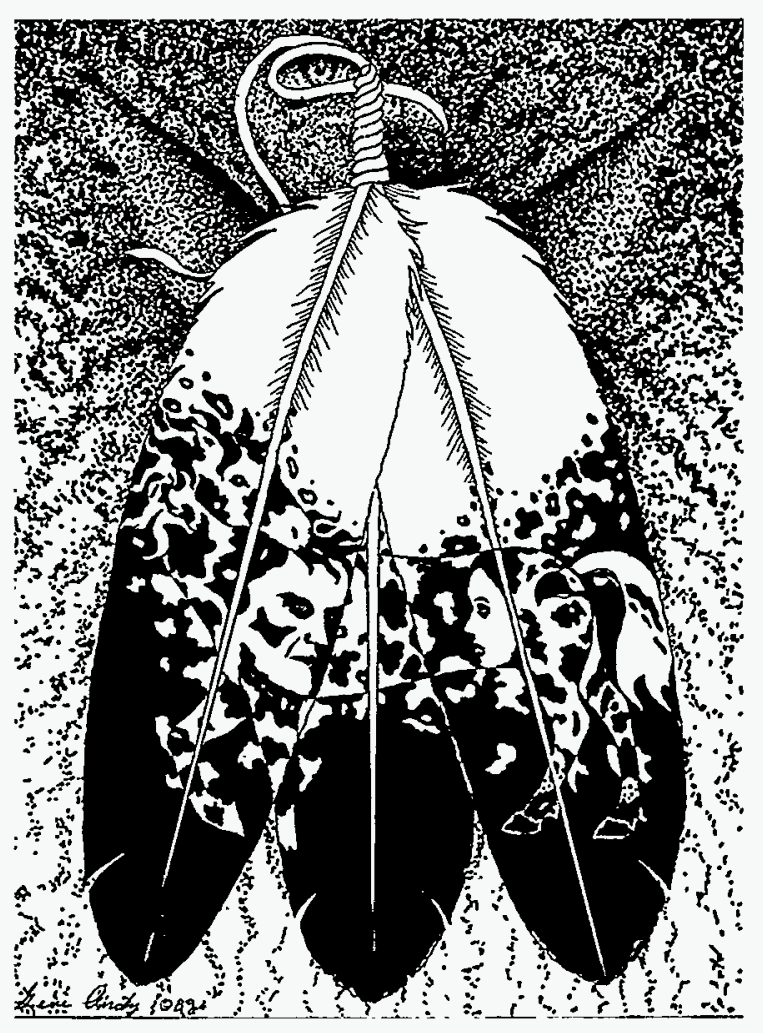

armed conflict. The following account, taken from the Smithsonian Institute's Handbook of North American Indians, History of Indian-White Relations, states:

"Large numbers of White settlers arrived in Oregon during the 1840s... and as their numbers increased, conflicts arose with the many small Tribes of Indians who inhabited the Pacific Northwest. Missionaries had set up stations in the 1830s, but they were unable to quell antagonisms, and when Marcus Whitman, his wife, and other Whites were killed by Indians in 1847, the Federal government realized at last the need for official administration of the territory...(H)owever, not until June 5, 1850, did Congress extend the provisions of the trade and intercourse act to Oregon and otherwise provide for Indian affairs in the region. Commissioners were appointed to negotiate treaties with the Indians, with instructions to extinguish Indian title to all lands west of the Cascades to concentrate the Indians on reservations. They met resistance to their plans from the Indians, and the six treaties they negotiated were 
rejected by the Senate. Subsequent treaties, too, failed to be ratified. In 1854-1856 new treaties with the Tribes in Oregon and Washington were negotiated.... $(T)$ he treaties extinguished Indian title to most of the land in the Pacific Northwest, assigned the Indians to reservations, and provided annuities and other assistance. The treaties with the coastal Tribes recognized their fishing rights. Meanwhile, the movement of miners and settlers into Oregon and Washington precipitated severe conflicts with the Indians that ranged through the mid 1850s (Rogue River and Yakima war), and new warfare broke out in 1858."

Pressed to clear the land for white settlement, the federal government began negotiations with various Indian tribes in the territory. In the summer of 1855 , the Walla Walla valley was the site selected for treaty talks with the inland tribes of the area, including the tribes and bands of the Yakama people.

By May 29, 1855 most of the expected Indians had arrived, and accordingly, at two that afternoon, the council was formally opened. Joel Palmer and Isaac Stevens sat beneath the arbor with their secretaries, agents and interpreters, while the Indians gathered in a vast semicircle before them. The number of Indians is in dispute, with one source claiming two thousand, another saying one thousand, and Kip estimating five thousand. What ever the actual number, there was a significant representation of the region's population of about fourteen thousand Indians. This may not have pleased Stevens, who preferred dealing with tribal notables. It is possible that he either was ignorant of or disregarded the Indian belief in communal ownership of the land and that, in theory at least, no chief or group of chiefs had the power to sign away what belong to all.

The leaders of the Yakama People of that time were devastated to learn of the threat of losing all the resources. The Yakama attendees said very little during the first days of the 1855 treaty council. When they finally spoke, they expressed four objections to the federal proposal.

First, they did not believe Stevens and Palmer, the United States Treaty Commissioners. A second concern was that the treaty commissioners had not consulted with the indigenous peoples on the location of the reservations. These United States representatives had drawn up the reservation boundaries "without our having any voice in the matter," Young Chief stated. The intent of the federal government, of course, was to separate the Nch' i-wana (Columbia River) Plateau People from their ancestral lands and resources, and to obtain lands for the railroad and for the benefit of immigrating farmers. To the Yakama Peoples, this meant leaving religious, spiritual, cultural and traditional areas. This was most troubling, since nearly all lands proposed to be ceded contained the graves of their ancestors. Culturally and spiritually to the Yakama Peoples present at the Council, this meant being torn from their ties to the past, a traumatic deprivation that would leave them alone in the present. The final concern of the Yakama Peoples attending the treaty council was that they would be obliged to live with tribes other than their own.

After 13 days of negotiations, the Yakama Treaty was finally signed with much anguish by Chief Kamiakin, head of the 14 tribes and bands of the Yakamas on June 9, 1855. Indian leaders who also signed the treaty were Skloom, Wohi, Tecole-kun, La-hoom, Doo-lattoose, Sch-noo-a, Meni-nock, Shee-ah-cotte, Sla-kish, Elit Palmer, Tuck-quille, Wish-och-knipits and Ka-loo-as. With the signing of the treaty, the Yakamas were forced to relinquish nearly 11 million acres of their homeland. They were allowed to keep 1.2 million acres, known at first as the Simcoe Reservation and later as the Yakima Reservation.

To the Indian people, the treaties were looked on as a means of ensuring survival for their tribes and for retaining at least a portion of their homeland. Regarding their treaties as a sacred 
pledge on the part of the federal government, the tribes viewed their agreements as valid as long as the United States existed.

Four long years would come and go before the treaty was ratified by the Senate on March 8 , 1859. James Buchanan, as President of the United States, signed the Yakama Treaty on April 18, 1859. This delay increased tensions between Indians and whites and led to the eventual outbreak of hostilities in 1855.

Even though the Yakama Treaty would not be ratified by the Senate and signed by the President for four years, Governor Stevens distributed legal notices to the Northwest newspapers declaring the ceded lands in all Indian treaties to be open and available for white settlement only a month after the treaty signing. Kamiakin led a group of Indians from several of the area tribes and bands to resist Steven's plan to open their homelands to white people. Military expeditions against the Yakamas and the other tribes in late 1855 failed to quell the uprising. In the spring of 1856 , a strong command was sent to occupy the Yakama country, especially the vital fishing sites. By late summer, the war had drawn to an inconclusive close. The unrest in the Columbia basin continued until the spring of 1858. In May 1858, a force of Spokane, Coeur d'Alene and Palouse warriors attacked the military command of Colonel Steptoe, who eventually escaped to Fort Walla Walla. The Indian force was later defeated at the Battle of Four Lakes on September 1, 1858, and at Spokane Plains on September 5, 1858. Shortly thereafter, 15 Indian leaders were hanged by Colonel Wright at Latah Creek, near Spokane. Kamiakin escaped the hangings, but Chief Owhi was shot and killed at Latah Creek. Thus, the Yakama War drew to a close in 1858. The bands and tribes of the Yakama retired to their reservation and began to learn farming.

Farming brought a change in character not only in the Yakama traditional way of life, but in the character of the land itself that the Yakama reverenced. Many things changed with the passage of the Allotment Act (Dawes Act) in 1887. Under the Allotment Act, the federal government divided communal lands into individual holdings. Individual tribal members were given title to 80 acre allotments, and "surplus" lands were sold to whites. Most of the first allotments were found along the larger watercourses. By 1900, all lands along streams and containing sub-irrigation were allotted. Also, all lands seen fit for irrigation were claimed, as were even the arid places populated by sagebrush, even though no water was yet available for irrigating those arid lands. Government representatives realized that for most people to subsist through agriculture, more land would have to be brought into production. Numerous wetlands were drained, and other areas were leveled and filled to obtain additional agricultural lands. Accordingly, several ditches were constructed. By World War I, a large-scale irrigation system, the Wapato Irrigation Project, was in place.

As the Allotment Act was implemented, followed by the spread of irrigation agriculture, many former grazing lands were no longer available for grazing. Allottees with irrigable land tended to rely on agriculture as a means of subsistence, while those without irrigable lands tended to rely on livestock. Sheep in particular became big business.

By the early 1900 s, sheep grazing was eclipsed by that of cattle. During the 1930s, various Indian cattle associations were formed. Many Indian families made their living raising cattle, and a few still do.

Non-Indians gradually gained control over reservation lands. This was accomplished through the purchase of lands of deceased Indians through their heirs, through the purchase of Indian lands that had received fee patents, and through the leasing of Indian allotments. Indians were encouraged to sell the lands they inherited by government representatives and other whites. In 


\section{Forest Management}

Until the 1940s, forest management was primarily fire control with some individual allotment harvest. In 1941, the general council decided to sell tribal timber. The first formal forest management plan was developed in 1942. Timber harvesting under this plan began in 1943. Nearly all cutting was directed toward Ponderosa pine stands where western pine beetle outbreaks were near epidemic levels.

As long-range management objectives were developed, forest management plans were prepared and updated. The basic policy in the beginning was to bring the reservation forest's virgin stands into a managed state compatible with sustained yield objectives. This policy evolved over the next five decades into a multiple use policy integrating Yakama social and cultural values and goals with their economic goals for the future.

The Yakama Indian Reservation is the homeland of the Yakama People, and as such possesses important religious and spiritual values. Concern is often expressed regarding how all values of the forest ecosystem will be maintained or enhanced. To protect these values several areas within the forest are removed from commercial timber production. These sites include food and medicinal plant areas, sites of traditional cultural and spiritual use, and current-use sites. On areas where commercial timber production occurs, the primary objective is to protect the forest ecosystem while sustaining the production of timber in balance with other values. These values include: soil productivity, water quality, old growth, native vegetation, fish and wildlife populations and habitats, archaeological and historical properties, employment opportunities and income to support the economic needs of the Yakama Indian Nation.

Since harvest began in the 1940 s, the Yakama tribal leadership has established a special version of multiple use, incorporating specific values unique to the Yakama people. As a result, uneven-aged management is the preferred silvicultural system. Harvests include a mix of single tree, group selection and small patch cutting practices that produce an uneven-aged structure. Some of the specific tribal desire that are incorporated into current silvicultural systems include the following:

- Maintain long-term ecosystem productivity and function.

- Consider all values of the forest during all levels of the decision-making process. Although the Yakama nation depends on the forest for most of its annual income, management decisions will not be based on monetary value along.

- Maintain a natural appearance in the forest.

- Maintain large diameter trees.

- Maintain stands that contain diversity in species, size class, and structure.

- Prohibit the use of pesticides and herbicides.

the long run, irrigation benefited non-Indians the most, for they gained access to and even control of land and water through the purchase and lease of Indian allotments.

Fences, farms and ranches are a living testimony to the effectiveness of the Allotment Act. As a person drives through the valley, he can consider the landscape of the past. When the road begins to wind upward, leaving the valley floor behind, the world of the desert roots comes into view. It is a garden of wild foods. This area persists up to, and even a little past, the Mill Creek Guard Station, where the road begins to enter the Yakama Forest. The area where desert and forest meet has been used by Yakamas for untold centuries. It remains important today, and in terms of traditionally-valued plants and 


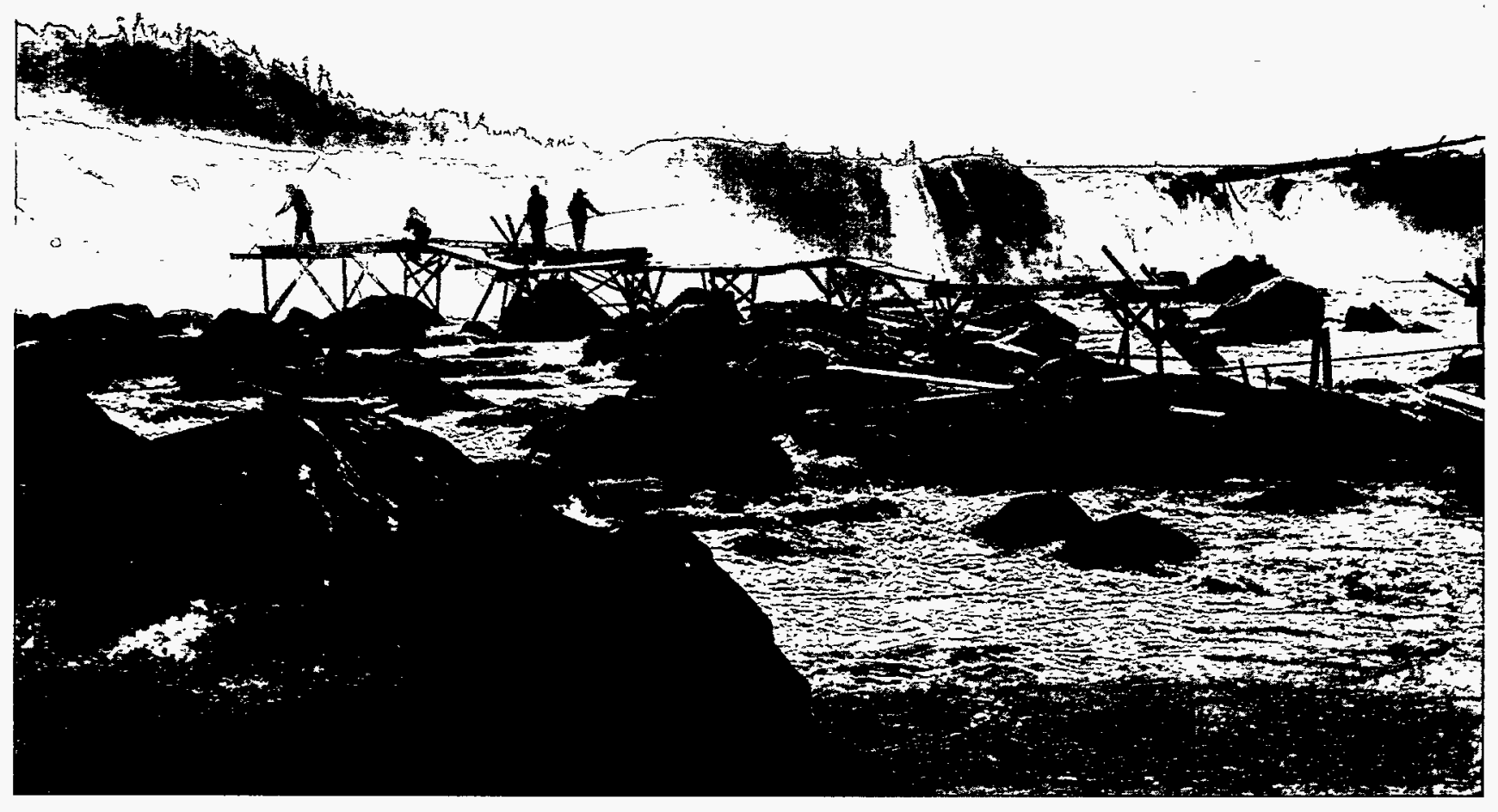

animals, cannot be easily matched by any other portion of the forest.

Removal to the reservation, white settlement patterns, and federal law profoundly changed the land, and the Yakama Peoples' relationship to the land; but as the 20th century dawned, these same factors were profoundly changing another great source of spiritual and cultural nourishment to the Yakama: water, in particular, Nch' i-wana, the Columbia River.

The Nch' i-wana was the lifeline of the Yakama People in the past, and still is. The watershed of the Nch' i-wana is a vast network of resources that housed, fed and clothed the people of the Fourteen Tribes and Bands. Stretched along the life line were places of residence with all the associated qualities that endear the landscape to the people. Villages, "winter residences," were characterized with play areas, gathering areas, and communal houses, or long houses, and were associated with nearby internment of the ancestors.

The development of hydroelectric and other major system uses of the Nch' i-wana began a disruption of the food chain that was largely unanticipated. Neither the federal government nor the Native American leaders were prepared for the massive reduction in productivity of the Nch' i-wana watershed. Loss of fisheries habitat quickly began to cripple the traditional lifeways of Yakama Peoples as access to and productivity of their fisheries plummeted.

The entire Nch' i-wana watershed, with all its vast spawning habitats played a role in the production of the salmonids that passed through the Yakama Nation's traditional fishing grounds. In this sense, the blockage of salmon runs by the Grand Coulee Dam, the plowing of a stream 
adjacent to Arrow Lake in British Columbia, the over-fishing of Redfish Lake in the hinterland of what is now Idaho, all had their contributions toward destroying the viable fisheries of the traditional fishing sites of the main stem, that now lie as dormant as archaeological ruins.

\section{INTO THE FUTURE}

The Yakama Indian Nation is considered a treaty nation made up of 14 tribes that signed the treaty of 1855 at the Walla Walla treaty grounds. The treaty reserved an original portion of their homeland totaling 1.3 million acres. The nation ceded over 12 million acres during those peaceful negotiations and provided treaty rights on those ceded lands outside the reservation. Among treaty provisions are the right to fish, hunt and gather at all the usual and accustomed places on the reservation and ceded area.

The Yakama Indian Nation rejected the Indian Reorganization Act of 1933, called the Wheeler-Howard Act, which returned unallotted lands on the reservations back to the tribes in the disastrous wake of the Allotment Act, and appropriated development funds for tribes that reorganized their governments along corporate lines. Instead of reorganizing on a corporate model, in 1933, the tribe elected to restore their Indian leadership, which had been decimated by warfare. A representative was selected from each of the 14 original bands and tribes of the Yakama confederation, and the government was formally established in 1944. Governmental affairs are run through a committee system which reports directly to the tribal council. A general council, comprised of all enrolled tribal members over the age of 18 years, elects the members of the council to represent the Yakama Nation.

The general council conducts annual meetings, usually the last week of November. Tribal protocol may delay the meeting by a tribal member's death or inclement. weather. Major Yakama Indian Nation issues are addressed and

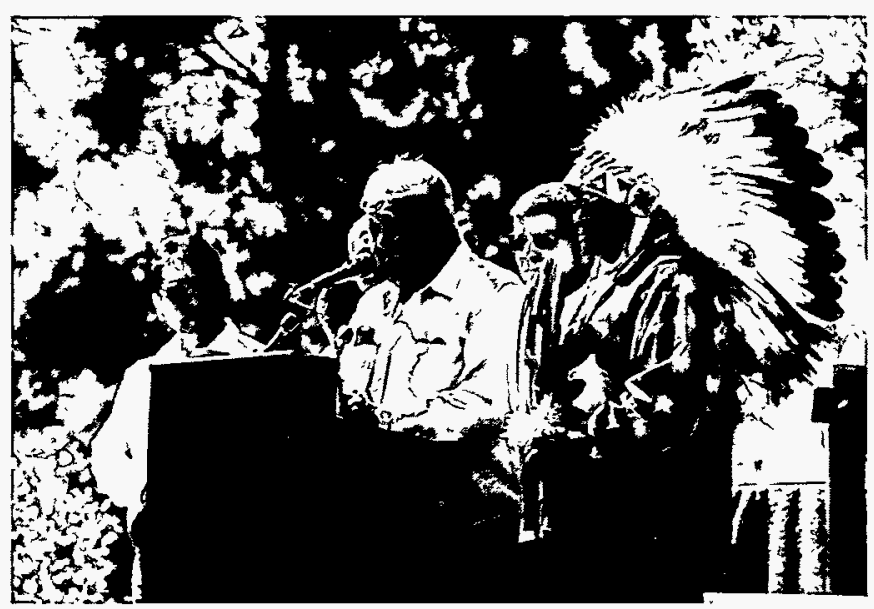

acted on. Tribal council members are elected at the general council meeting. Of the 14-member tribal council, seven members are elected every second year at the general council, and serve fouryear terms. Tribal council members are appointed to committees, of which their are eight standing committees and seven special committees. Legislation passed by the general council is in resolution form that is passed and approved by the total membership. These legislative acts are laws of the Yakama Indian Nation. For instance, in 1994, the symbolic spelling of the tribe was changed by Resolution T-053-94 from "Yakima," in order to reflect the name originally used in treaty negotiations: "Yakama."

The Yakama Nation is now pursuing a strategic plan, "...a comprehensive approach to job creation and prosperity for the Yakama Indian nation and its people in the 21 st century." Bringing together the vision of the elders and the vigor of the youth the strategic plan represents an effort to coordinate and integrate a plan of action for the reservation. A score of different projects designed to expand existing projects or to start new endeavors will provide jobs and revenues in a variety of fields categorized into agriculture, natural resources, industrial development, recreational tourism and human resources. 


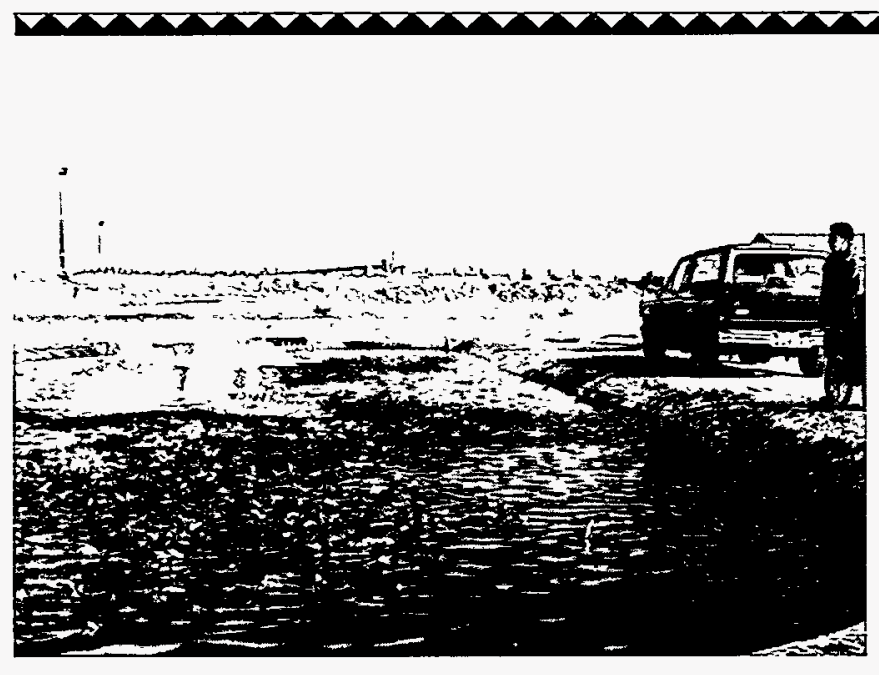

\section{Cle Elum Hatchery}

The Cle Elum Hatchery now under construction in Cle Elum, Washington is the result of many years of hard work and cooperation from the Yakama Indian Nation, Bonneville Power Administration (BPA), Washington Department of Fish \& Wildlife (WDFW), Northwest Power Planning Council (NPPC), local citizens and countless others. When completed, the innovative $\mathrm{Cle}$ Elum Hatchery will serve many functions, including: holding and spawning upper Yakima spring chinook adults, incubating eggs and rearing of young fish. The facility will use about 15 acres of land, and will include holding ponds, raceways, groundwater wells, a pump station on the river, a settling pond for waste treatment, a storage building, offices, research facilities, interpretive areas, parking and residences. $\mathrm{A}$ visitors center will be built and it may be expanded in future years.

The project is part of the NPPC's Columbia River Basin Fish \& Wildlife Program and will mitigate for the decline of anadromous fisheries (those species that rear in fresh water, migrate to the ocean and develop to maturity in salt water, and return to their natal streams to spawn), which has been attributed to the development and operation of hydroelectric projects in the Columbia River basin. In short, BPA-sponsored fish projects in the Yakima River system mitigate for stock losses that have occurred elsewhere in the basin. Other factors contributing to the decline of the fisheries include irrigation, mining, pollution and forest clear-cutting, which destabilizes stream banks and leads to siltation on the spawning beds and in rearing habitats.

The Cle Elum Hatchery will be the first large-scale test of the "supplementation" method over conventional hatchery practices. The supplementation approach differs from conventional hatcheries, where cycling of generation after generation of fish through the artificial rearing 
process may lead to weakening of the stocks. Problems include loss of genetic diversity, as well as the associated problems of domestication and loss of physical and behavioral traits needed for survival outside the hatchery.

Here's how it works: Broodstock will be collected at Roza Dam, transported to the central hatchery facility and held there for spawning. Eggs will be incubated and fry will be reared at the hatchery. Rearing of half the fish population will include methods to encourage adaptation to the natural environment. For example, juvenile salmonids will be taught to forage for food. The other half of the fish will be reared using conventional methods, and survival under the two methods will be compared.

When ready, the juveniles will be transferred from the hatchery to one of the acclimation sites, which will be located next to the spawning grounds where the fish will be expected to return as adults. The acclimation sites are particularly important to the success of these juvenile fish because they reduce stress associated with transportation from the hatchery, and allow the fish to "imprint" on the water in which they will be released (the latter point refers to a learning process the fish go through to identify their future spawning grounds). When sufficiently mature, the young smolts will leave the acclimation facility for an out-migration to the ocean. Adult fish will be expected to return in one to four years to spawn.

The innovative practices and facilities will allow the natural process of fish rearing to be "supplemented" rather than artificially "replicated." The process is designed to increase the fish population being supplemented while minimizing adverse genetic and ecological interactions with other species or stocks. Ultimately, it is hoped that enough naturallyspawning fish will return with a high enough survival rate that artificial propagation can be phased-out. The supplementation research program will monitor post-release survival of fish, reproductive success, longterm fitness, ecological interactions, stock status and other outcomes. Afterwards project managers may modify programs, procedures and facilities in response to findings. This process is otherwise known as adaptive management. 